\title{
فاعلية برنامج قصصي لتنمية الوعي الصحي لاى أطفال الروضة ذوي الإعاقة العقلية البسيطة الصئة
}

إعداد

د/ إسراء رأفت محمد علي شهاب

مقدمة

لقد ميز الله الإنسان بعقله وذكائه عن باقي المخلوقات، ولكن قدر على بعض البشر انخفاض نسبة

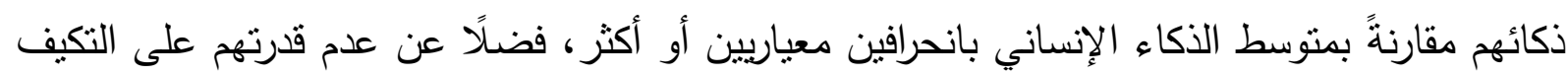

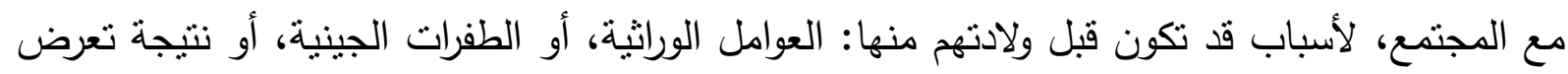

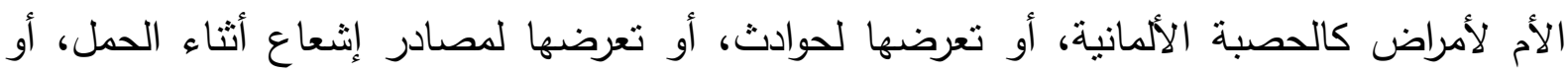

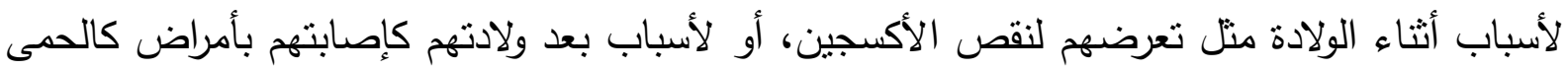
القرمزية، أو تعرضهم لحوادث، أو قد تكون الأسباب غير معروفة، ويصنفون من فئات ذوي الاحتياجات

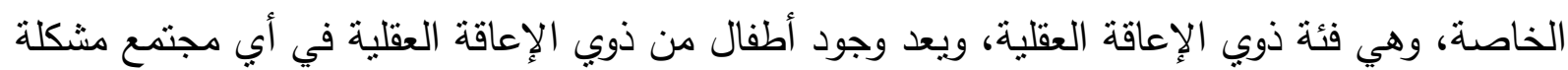

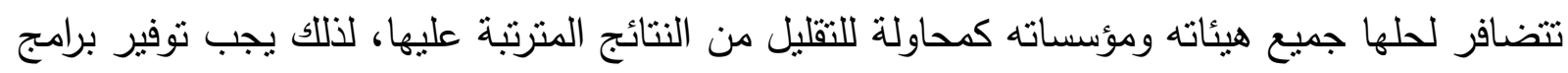
الرعاية المتكاملة لهم في جميع المجالات، ومنها نوفير المؤسسات التربوية التعليمية التي تهتم بتقديم برامج لهم لتتمية مهاراتهم، ودمجه في المجتمع، وهي روضات ومدارس التربية الفكرية. وتثبير نتائج المعايير الإحصائية وتوزيع السمات حسب المنحنى الطبيعي للأكاء إلى تقدير نسبة فئة المعاقين عقلياً بحوالي ب\% من نسبة السكان في أي مجتمع (Kastner, et al, 2001). بالرغم من قلة نسبة فئة المعاقين عقليًا في أي مجتمع؛ فأنهم يحتاجون لتوفير الكثير من الخدمات والرعاية والعناية والجهود البشرية والإمكانيات المادية، وبخاصة منذ ولادتهم وفي مرحلة طفولتهم المبكرة كتدخل مبكر لهم لتقليل من معاناتهم مع التقدم في العمر وعلى مدار حياتهم، حتى لا يمنلون عبنًَا ماديًا

$$
\text { وبشريًا على أب مجتمع فيما بعد. }
$$

وللإعاقة العقلية العديد من التعريفات، ومنها تعريف الجمعية الأمريكية للإعاقات العقلية American Association Intellectual and Developmental Disabilities بأنها قصور عقلي وظيفي واضح معبر عنه بانحراف درجة الذكاء انحرافين معياريين (AAIDD)(2010)

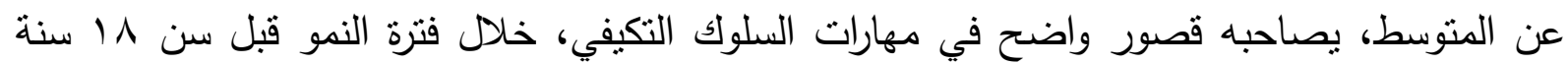
.(Hallahan, et al, ,2013 : 350) 


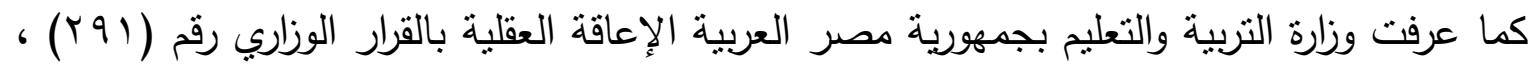

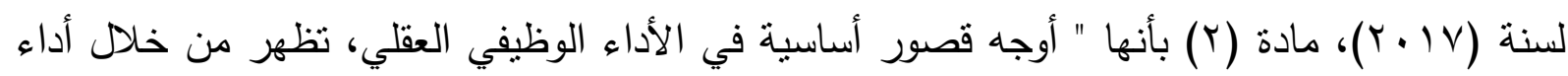

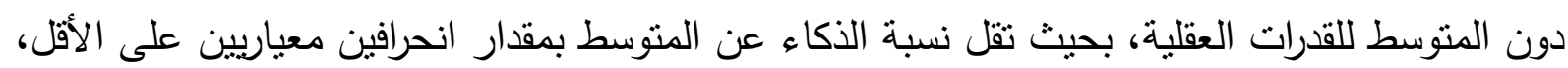
ويكون مصحوبًا بقصور في المهارات التكيفية، ذلك في اثثين على الأقل من مجالات التواصل، ونله والعناية

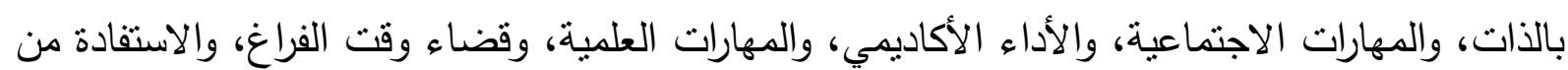

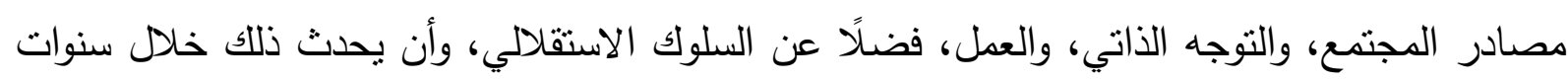
النمو قبل سن (1) العامًا.

حددث الرابطة الأمريكية للطب النفسي (2013) American Psychiatric Association، في Diagnostic and Statistical Manual الدليل التشخيصي الإحصائي الخامس للاضطرابات العقلية of Mental Disorders DSM-5 ، معايير تحديد الإعاقة العقلية فيما يأتي: - قصور عقلي يظهر واضحًا في جميع الوظائف العقلية، ومنها التفكير المنطقي، وحل

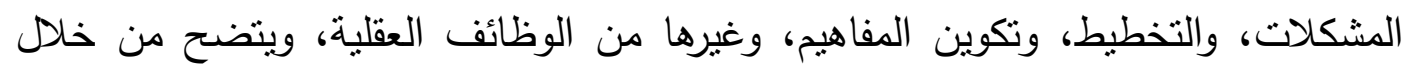

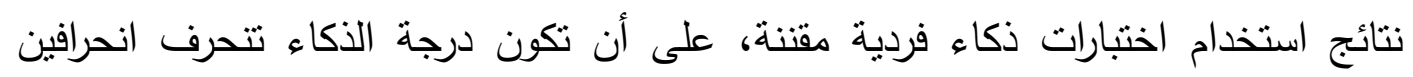
معياريين عن المتوسط، أي تكون • V درجة فأقل. - قصور في مهارات السلوك التكيفي، ويظهر واضحًا في القصور في أنشطة الحياة اليومية درجية

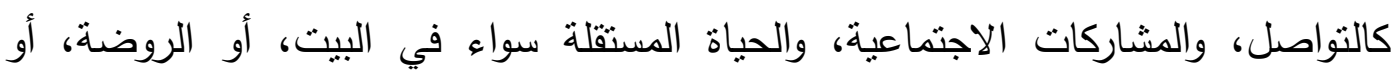

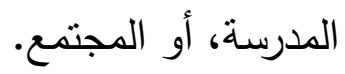
- أن يظهر القصور العقلي والقصور التكيفي خلال فترة النمو والتطور ، أب قبل بلوغ عمر 11 سنة.

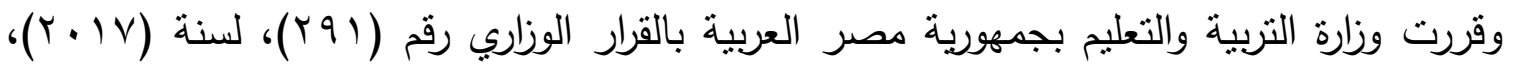

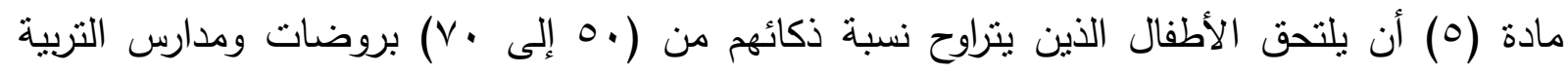

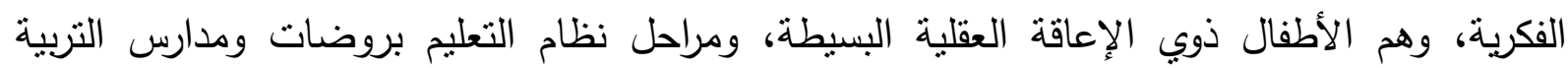

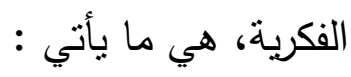
- مرحلة التهيئة ( الروضة): الدراسة بها مدتها سنتان. - - الحلقة الابتدائية: الدراسة بها لمدة ست سنوات. - مرحلة الإعداد المهني: الدراسة بها لمدة ثلاث سنوات.

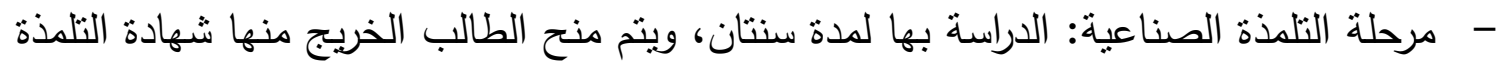

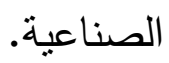


وقد حدت وزارة التربية والتعليم بجمهورية مصر العربية بالقرار الوزاري نفسه مادة (0) أهداف

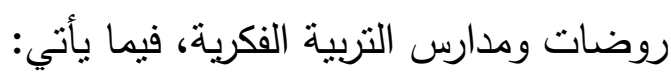

أولًا : أهداف روضات ومدارس التربية الفكرية، وهي:

- تلمية العادات الصحية؛ للمحافظة على الأطفال ذوي الإعاقة العقلية، وسلامة بدنهم. - تعزيز الصحة النفسية من خلال ممارسة تساعد على الإحساس بالأمن. - - ت تمية النقة بالنفس لاى الطفل.

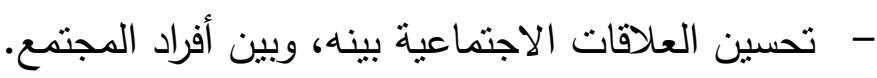
- ت تمية القدرات البصرية، والسمعية، والحركية، والعقلية لدى الطفل.

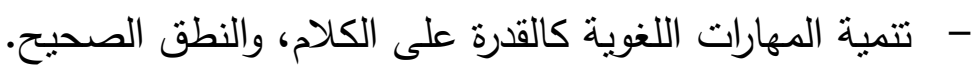
- تلمية المهارات والخبرات الحسابية، والمعلومات العامة اللازمة للأطفال ذوبي الإعاقة العقلية - لتنجية المهارات في اليدياة العملية. - ت تمية العادات والاتجاهات الاجتماعية السليمة، وغرس القيم الدينية والخلقية. - توفير التوعية الضرورية لأولياء الأمور •

ويتضح من خلال العرض السابق لأهداف روضات ومدارس التربية الفكرية أن من أهدافها تتمية

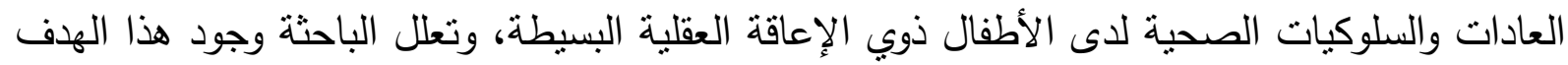
من أهداف روضاتهم ومدارسهم في ضوء ما يأتي:

1. كثرة مشكلاتهم الصحية، وضعف مناعتهم، ولقصور معارفهم واتجاهاتهم وضعف ممارستهم

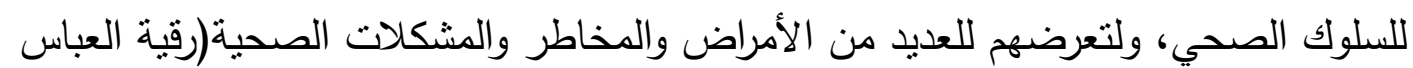

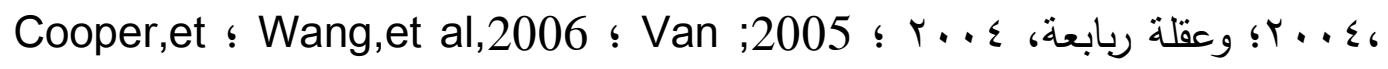

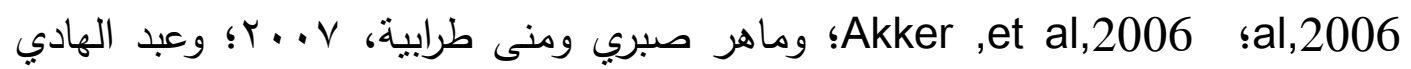

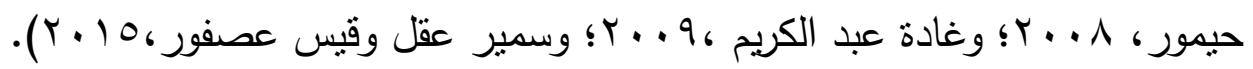

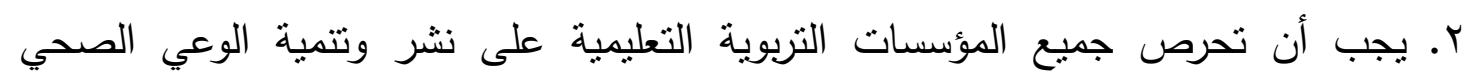

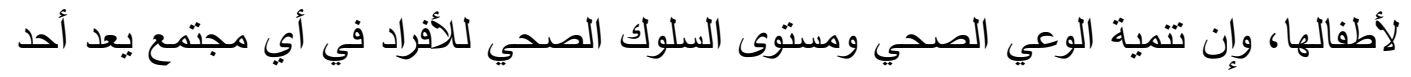

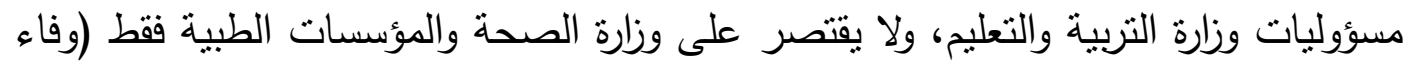

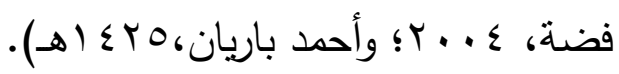
r. يجب توفير برامج لتتمية الوعي الصحي السليم، ضمن المناهج التعليمية المقدمة للمتعلمين

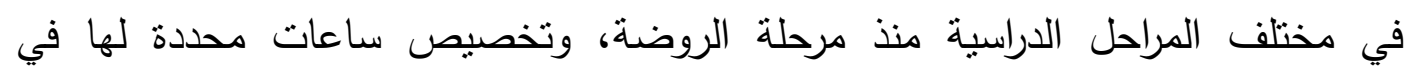
المقررات والمناهج والبرامج المقدمة للارسين مع التركيز على جوانب ممارسة السلوك 


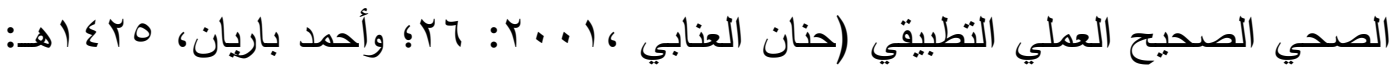

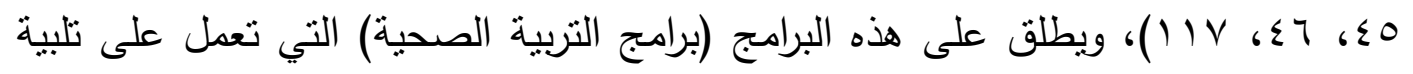
مطالب المتعلمين الصحية، وإكسابهر المعارف والاتجاهات نحو ممارسة العديد من السلوكيات الصحية التي يحتجونها على مدى حياتهم، ولوقايتهم من الحوادث والمخاطر والأمراض الثائعة المنتشرة التي قد تصيبهم في حياتهم(Gilbert ,et al ,2000:84؛ وبهاء

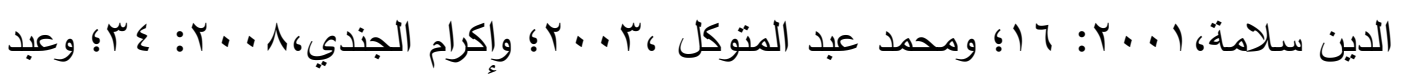

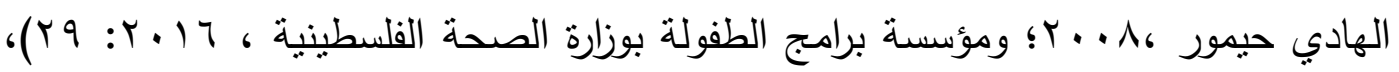
كما أن هذه البرامج تفيد في الحد من مشكلات الصحية لذوي الإعاقة العقلية التي يعانون

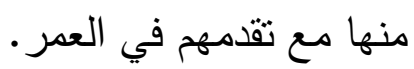
ء. يجب أن تقدم برامج التربية الصحية لتنمية الوعي الصحي في الروضات، أن أكثر فئة عمرية في المجتمع بحاجة لتتمية الوعي الصحي هم الأطفال في مرحلة الروضة، وإن الروضة هي أحد أهم المؤسسات المسئولة عن تتمية الوعي الصحي للأطفال، فيجب أن تكسب العادات الصحية الصحيحة للأطفال، وذلك يتم بسهولة في هذه المرحلة (عبد السلام

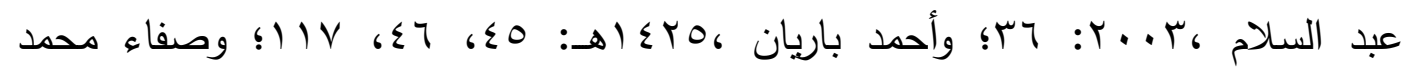

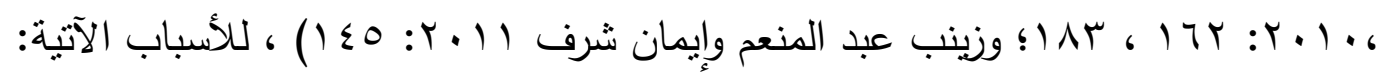
- الأطفال يقضون معظم وقتهم داخل الروضة. - قبول الروضة للأطفال في سن الطفولة المبكرة؛ يساعد على إكساب السلوك الصحي لهم، ويتطلب ذلك تدريب الطفل، وتمرينه عليها، كما تعد الروضة مكان مناسب لذلك.

كما أوصت العديد من الأدبيات والدراسات، ومنها دراسة ويليام ( William 2001:396، ومحمد

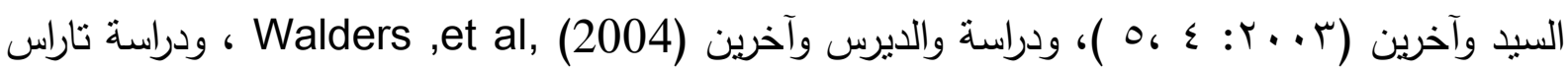

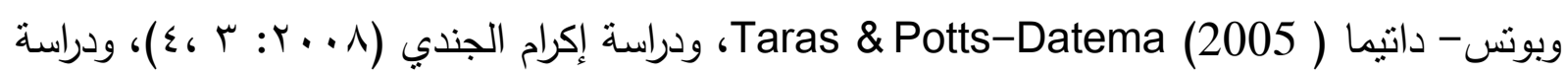

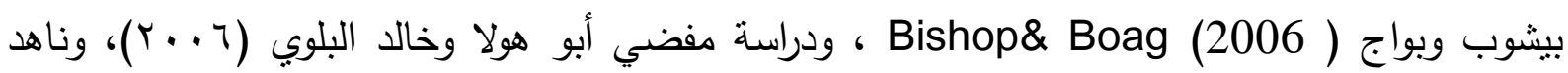

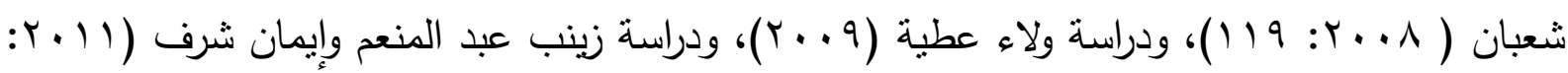

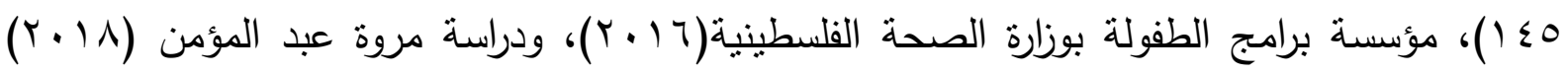
بأهمية تقديم البرامج التربية الصحية؛ لتتمية الوعي الصحي للأطفال في جميع المراحل الدراسية، وبخاصة في مرحلة الروضة لأن الأطفال في هذه المرحلة يسهل تشكيل سلوكهم وإكسابهم العديد من السلوكيات الصحية الصحيحة.

ه. توصيات العديد من الأدبيات والدراسات والبحوث السابقة التي نادت بضرورة توفير برامج لتمية الوعي الصحي للأطفال ذوي الإعاقة العقلية، حيث أكدت دراسة ميكهيرجي وآخرين 


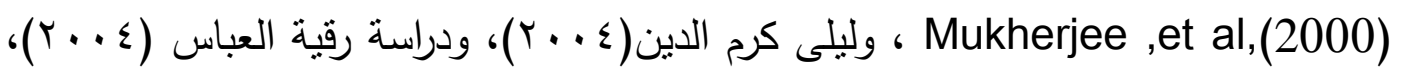

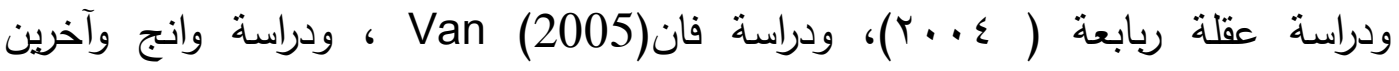

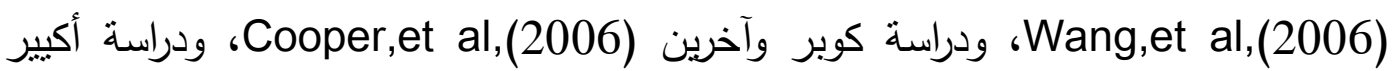

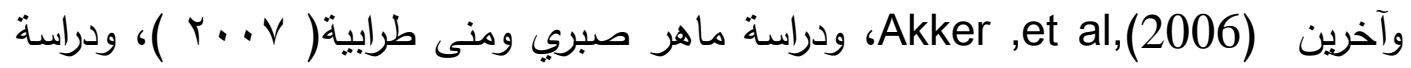

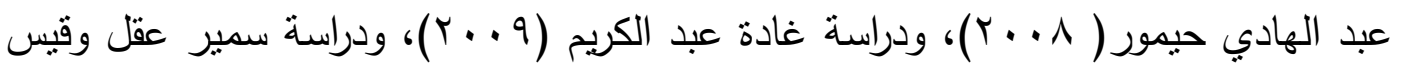

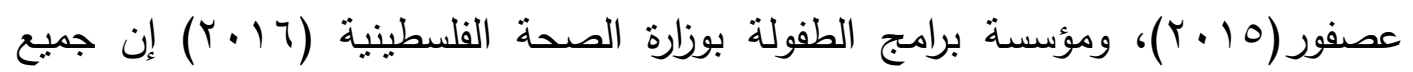

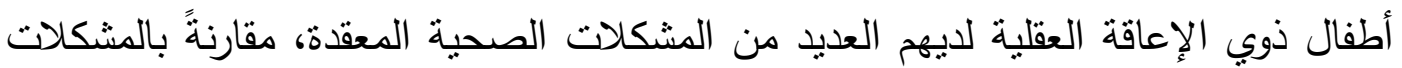

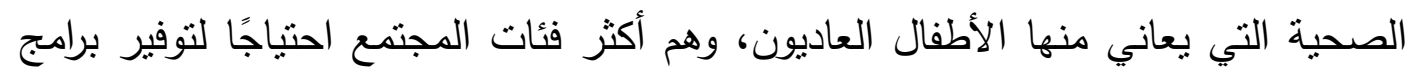

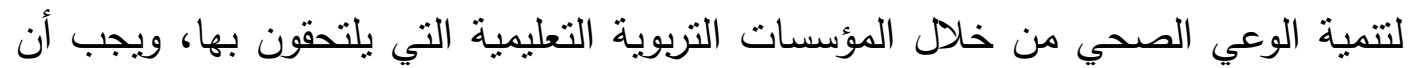
تتيح الروضات ومدارس التربية الفكرية العديد من الإمكانيات المختلفة للأطفال ذوي الإعاقة

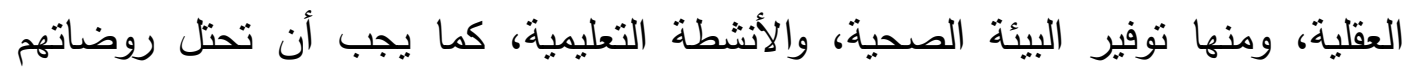

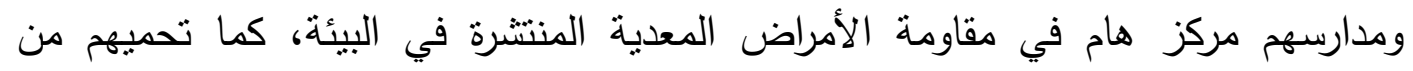
الأخطار والحوادث، وتعلمهم طرق الوقاية منها، وللتربية الصحية في مرحلة الروضة الهمانه أهمية

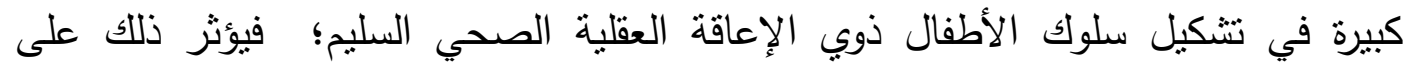
مستقبله فيما بعد.

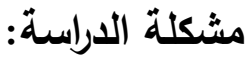

بالرغم من أن أهداف روضات ومدارس التربية الفكرية التي حددنها وزارة التربية والتعليم بجمهورية

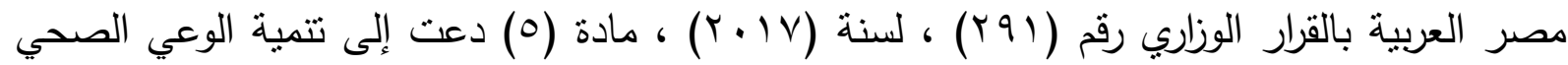
للأطفال ذوي الإعاقة العقلية البسيطة، بالإضافة إلى توصية العديد من الأدبيات والدراسات والأبحاث السابقة بتوفير هذه البرامج لهم منذ مرحلة الروضة، إلا أن واقع البرامج المقدمة للأطفال ذوي الإعاقة

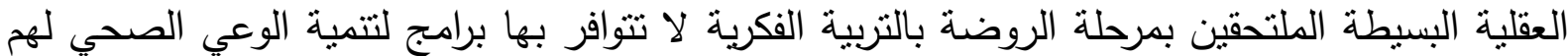

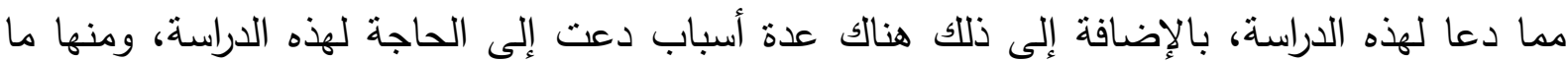

ا. ملاحظة الباحثة أثناء فترة عملها بروضات ومدارس التربية الفكرية التابعة لإدارة التربية الخاصة

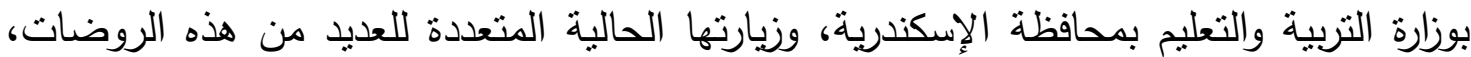

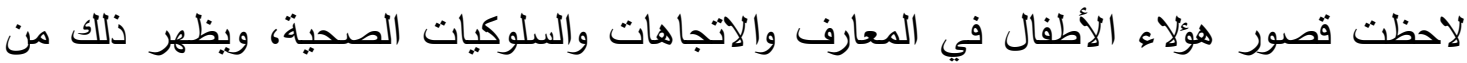
خلال ممارستهم للعديد من السلوكيات الخطأ صحيًا التي تصدر منهم في المواقف الحياتية

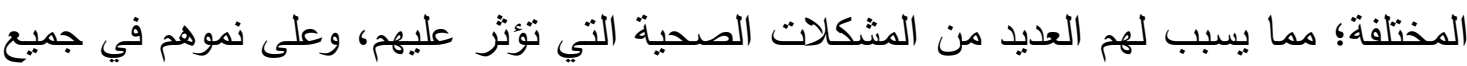


المجالات، بالإضافة إلى عدم وجود برامج للتربية الصحية لتتمية الوعي الصحي مخصصة لهم،

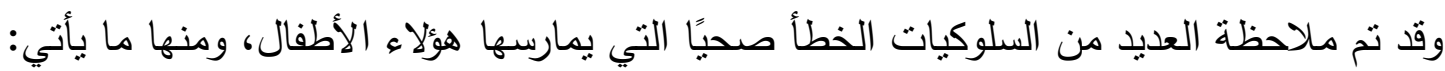
- - عدم غسل اليدين قبل الأكل أو بعده. - عدم غسل اليدين بعد استخدام دورات المياه. - قصور الاهتمام بالنظافة الثخصية، ومنها: نظافة الثعر، ونظافة الجسم، ونظافة الأسنان.

- عدم تغير الملابس باستمرار . - لبس ملابس لا تلاءم حالة الجو. - شراهتهم في تتاول الطعام؛ مما يؤدي إلى السمنة. - ميلهم لنتاول الأطعمة الملونة المصنعة.

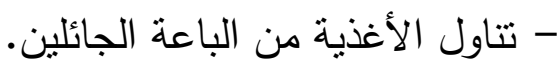

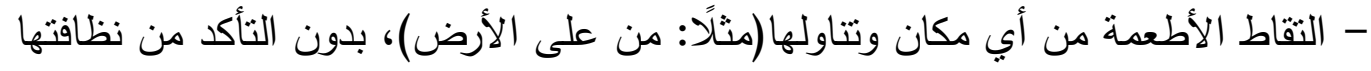

$$
\text { أو صلاحيتها. }
$$

- شرب ماء غير نظيف. - ت ت ت اول المياه الغازية بشراهة. - تعرضهم للثمس لفترات طويلة.

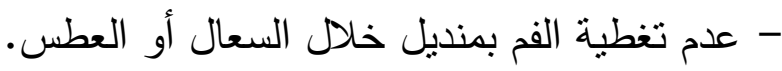
- استخدام أدوات الآخرين كأدوات المائدة. - الوقوف، والجلوس بطريقة خطأ؛ مما يؤدي إلى تشوهات في القوام منل انحناء العمود

- استخدام أدوية الكبار تقليدًا لهم، ومحاكاتهم. - الإهمال في نظافة المكان الذي يتواجد الطفل فيه.

$$
\text { - اللعب بالأسلاك والأدوات الحادة. }
$$

- رمي القمامة في أماكن غير المخصصة لها، والتقاطها وتتاولها مرة أخرى. r. نتيجة الدراسة الاستطلاعية التي هدفت استطلاع رأي أمهات ومعلمات الأطفال ذوي الإعاقة

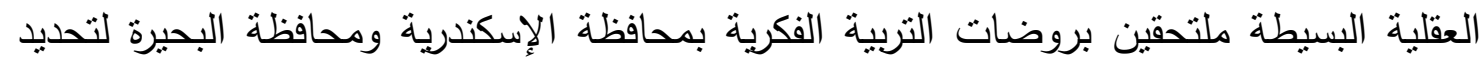

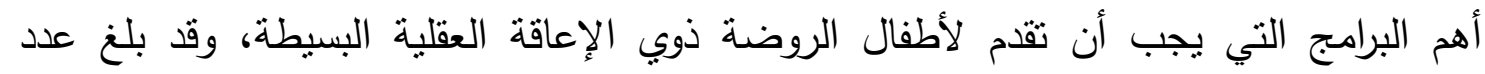

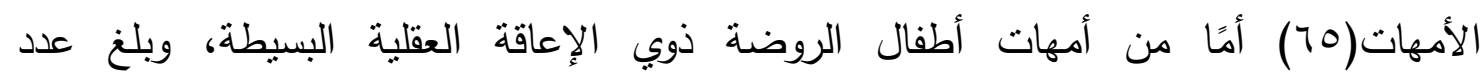

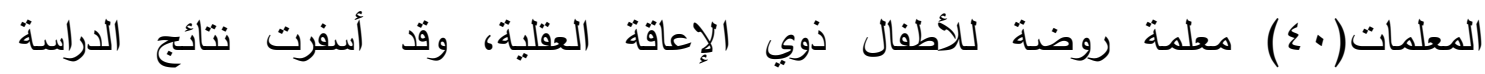
الاستطلاعية عن مدى احتياج هؤلاء الأطفال لبرامج التربية الصحية لتتمية الوعي الصحي لهؤلاء 
الأطفال في هذه المرحلة، كما أضافت العديد من الأمهات والمعلمات أن كثرة السلوكيات الخطأ

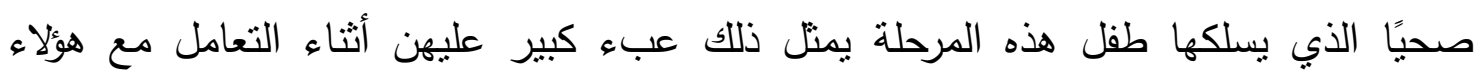
الأطفال.

r. ثأكيد العديد من الدراسات والأدبيات بمعاناة الأطفال ذوي الإعاقة العقلية من العديد من المشكلات الصحية، ومنها:

- Mukherjee ( أن الأطفال ذوي الإعاقة العقلية أكثر عرضة للإصابة بالأمراض المنتشرة -

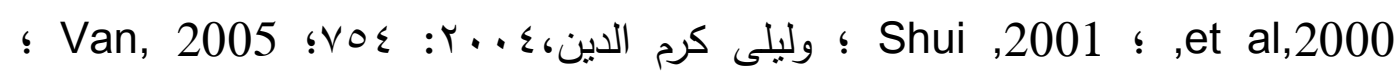

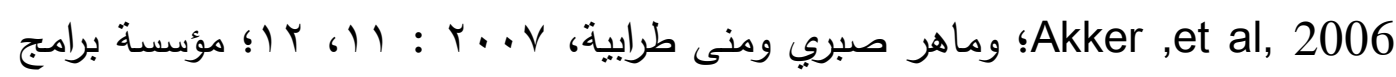

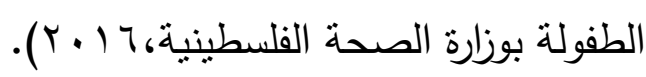

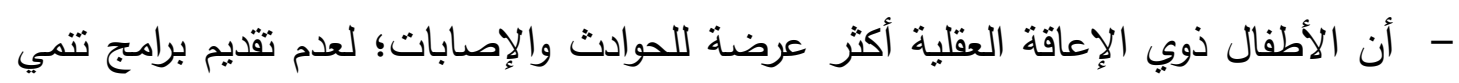

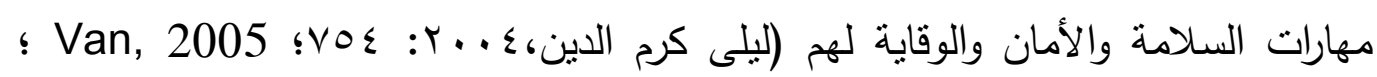

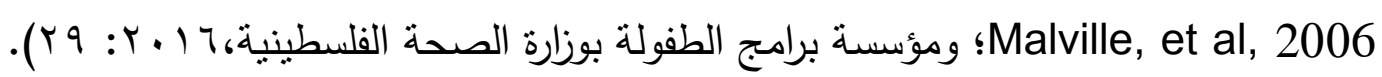

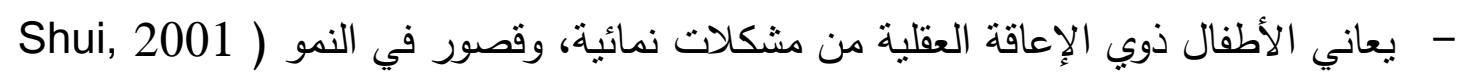

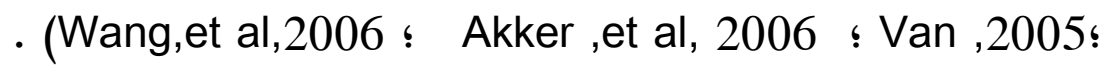
- يعاني بعض الأطفال ذوي الإعاقة العقلية من ضعف حاستي السمع أو البصر أو الاثثين Wang,et al,2006)

- - يعاني أغلب الأطفال ذوي الإعاقة العقلية من اضطرابات في الجهاز الهضمي. (Wang,et al,2006)

- يعاني أغلب الأطفال ذوي الإعاقة العقلية سهولة انتقال الأمراض الجلدية فيما بينهم. Wang,et al,2006)

- قد بعاني بعضهم من مشكلات في الكلى، والكبد، واضطرابات في عضلات القلب،

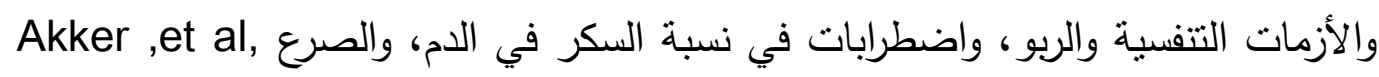
.(Wang,et al,2006 2006) - أغلب الأطفال ذوبي الإعاقة العقلية يعانون من أمراض السمنة، والثراهة في تتاول طعام

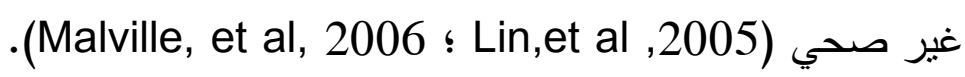

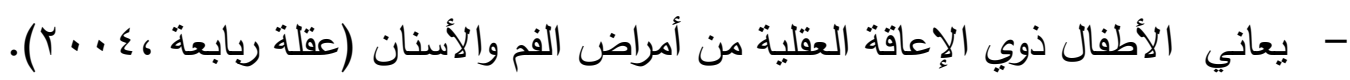

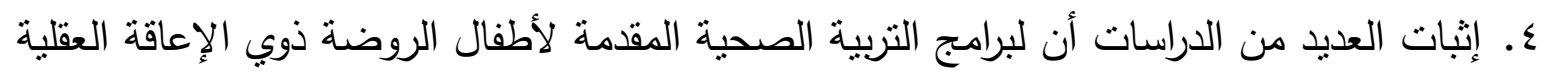

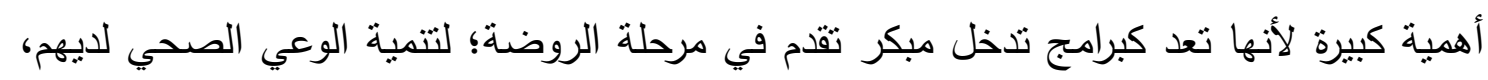


وللحد من المشكلات الصحية التي قد نواجهم مع تقدمه في العمر ، وإكسابهم المعارف البسيطة عن السلوك الصحي، وتعديل اتجاهاتهم وسلوكياتهم الخطأ صحيًا التي يمارسونها مع كبر فئر سنهم. ( Mukherjee ,et al ,2000; Wang,et al, 2006 ;Cooper,et al, 2006 )

هـ أهمية توفير برامج التربية الصحية المقدمة للأطفال ترجع إلى مواجنها لتأثثر الإعلانات المنتشرة

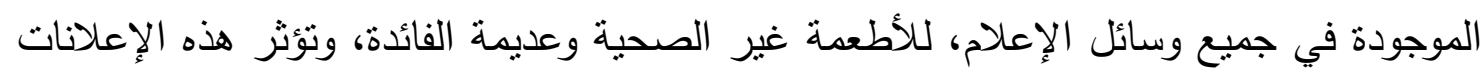

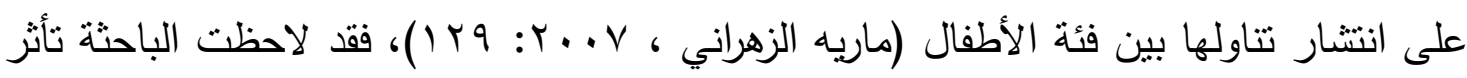

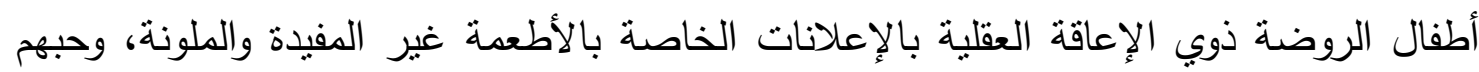

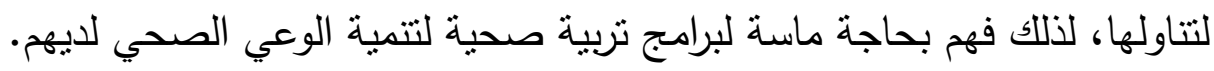

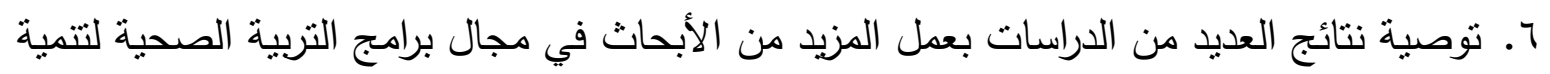

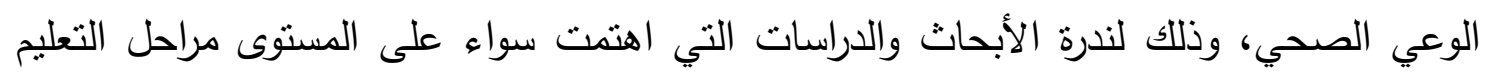

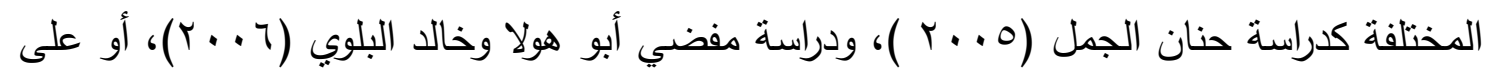

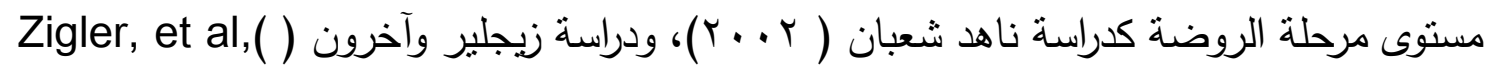

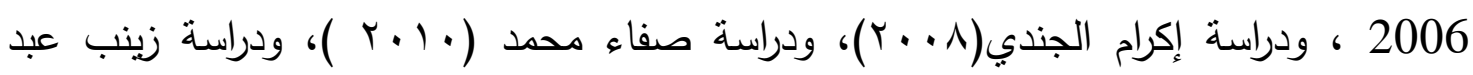

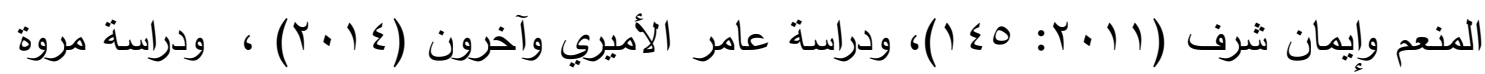

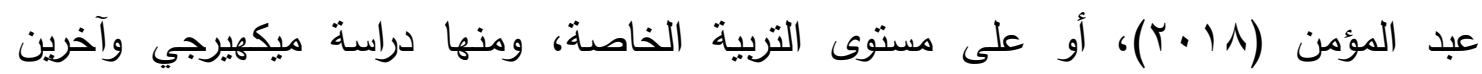

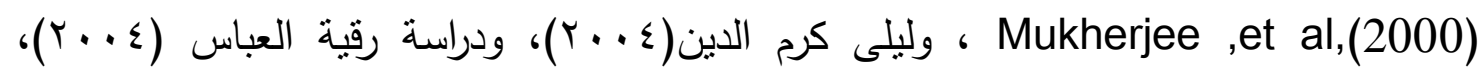

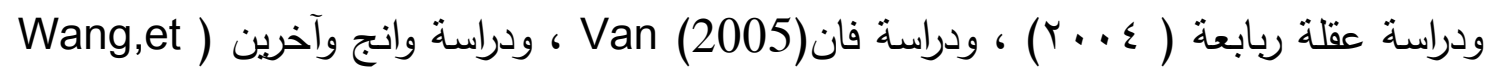

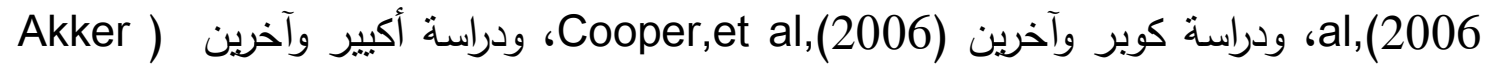

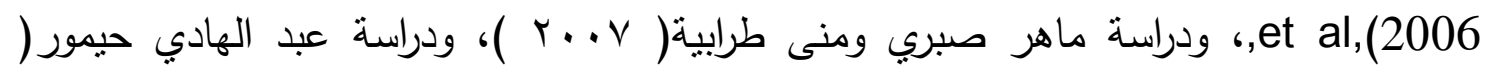

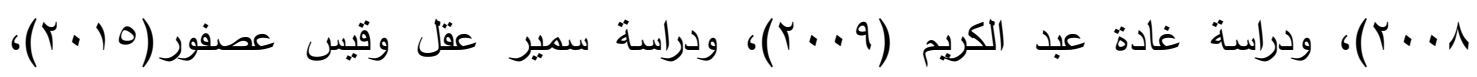

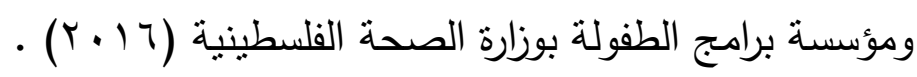

وبالرغم من تعدد الدراسات التي تم الحصول عليها التي اهتمت بالمجال الصحي وتتمية السلوكيات

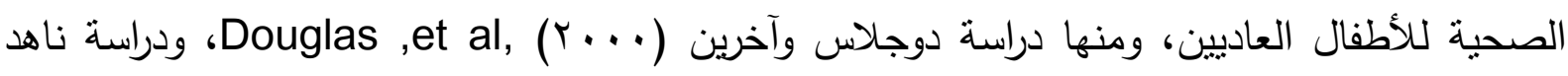

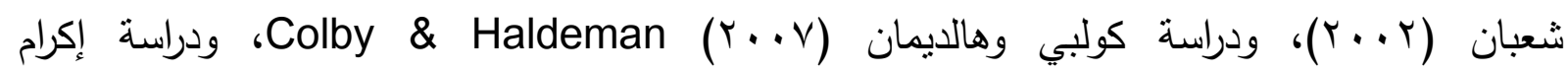

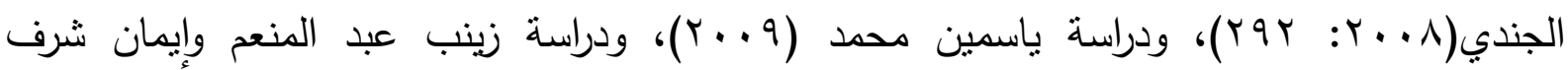
(1)

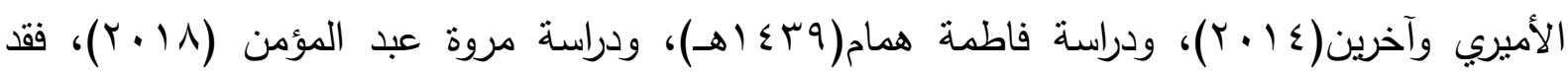

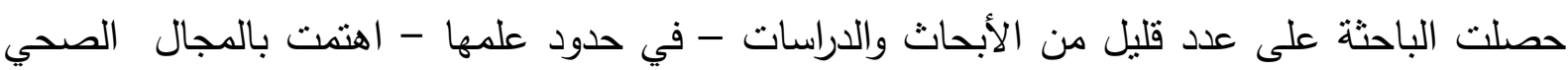

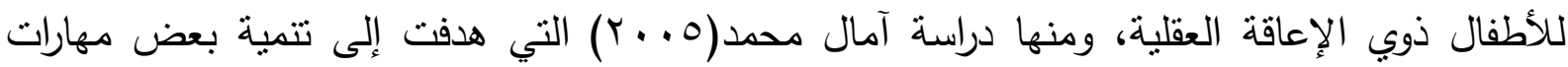


الصحة والسلامة للأطفال ذوب الإعاقة العقلية البسيطة من خلال برنامج قائم على جداول النشاط

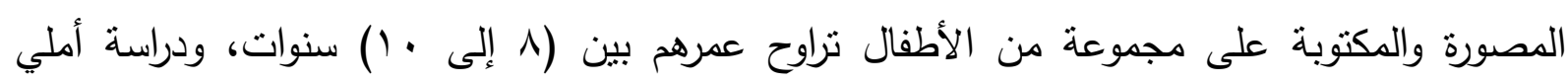

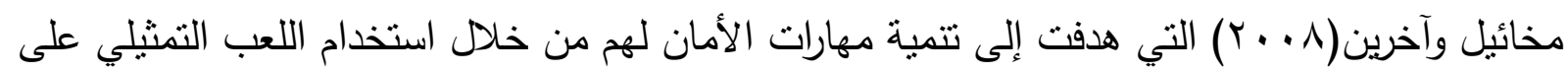

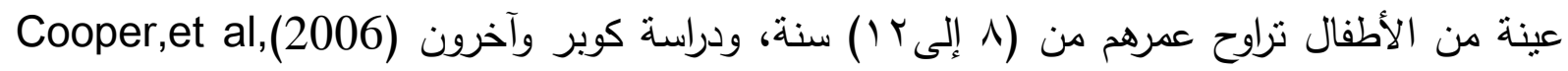
التي هدفت إلى تتبع تحسين صحة بعض الأطفال ذوبي الإعاقة العقلية بتطبيق برنامج للتربية الصحية

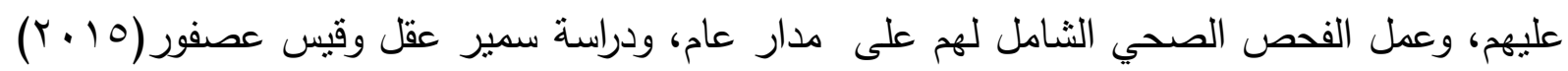
التي هدفت لتتمية الوعي الصحي من خلال التعليم المعزز بالحاسوب للأطفال ذوي الإعاقة العقلية في

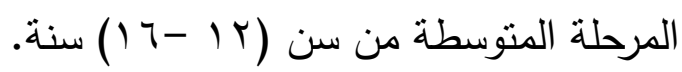

كما تم الحصول على بعض الدراسات هدفت تحديد المشكلات الصحية التي يعاني منها الأطفال

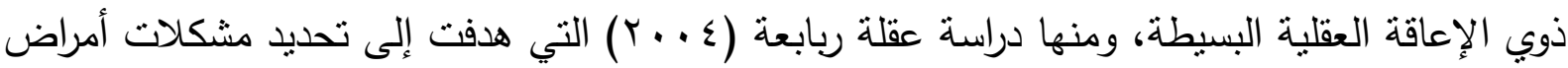

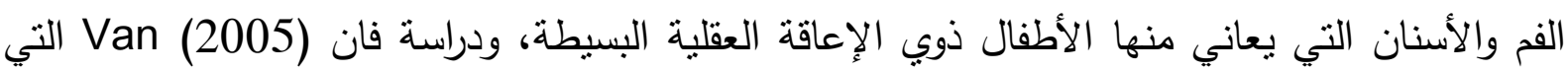
هدفت إلى تحديد احتباجات هؤلاء الأطفال الصحية، ودراسة وانج وآخرين Wang,et al,2006) التي التيان

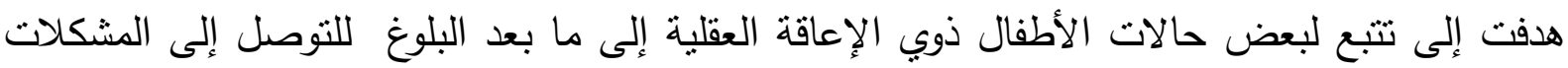

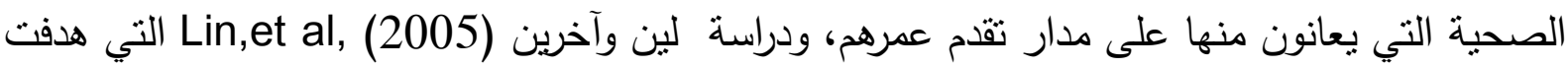

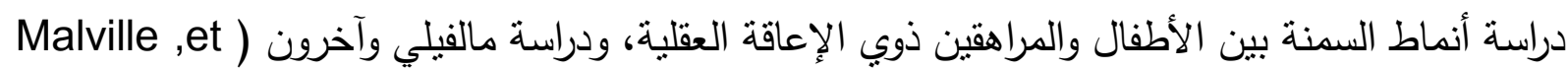

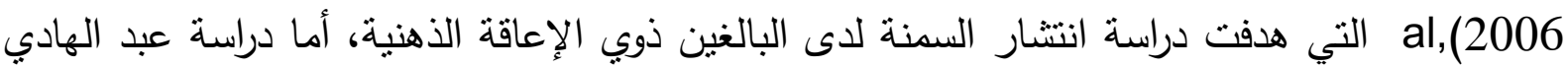

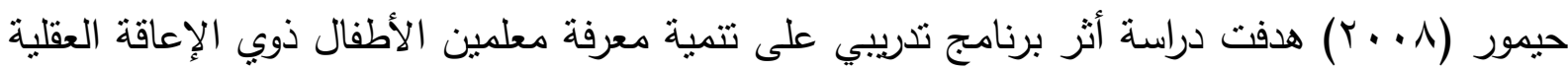
بالمشكلات الصحية التي يعانون منها هؤلاء الأطفال.

ولم تجد الباحثة أبحاث ودراسات سابقة - في حدود علمها - اهتمت بتقايم برامج للتربية الصحية

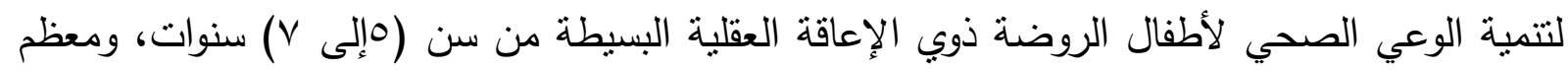

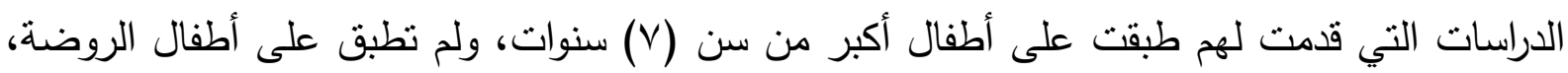

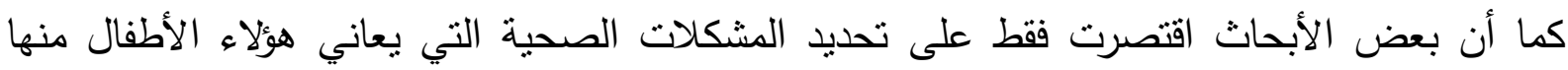

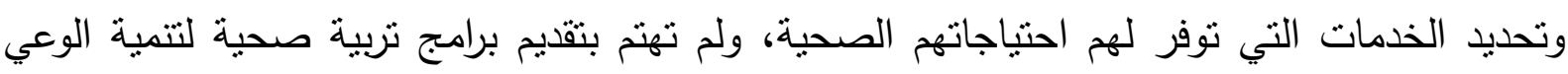

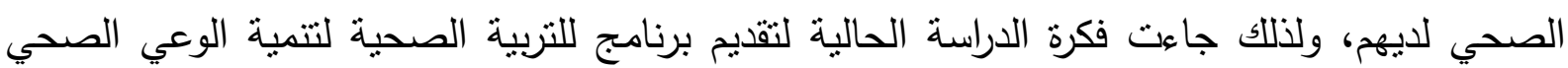
لاى أطفال الروضة ذوي الإعاقة العقلية البسيطة الملتحقين بروضات التربية الفكرية.

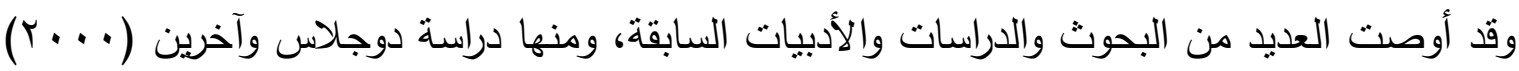
Douglas ,et, al,

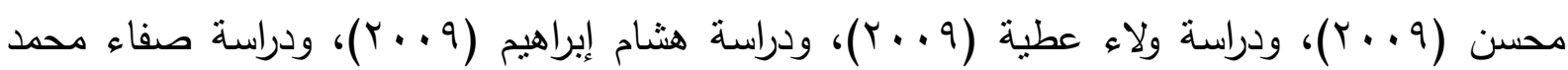

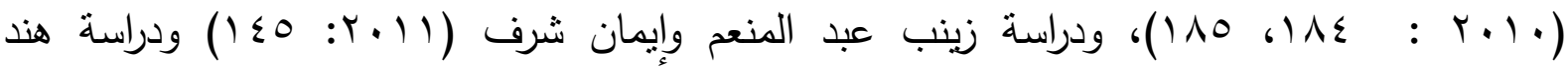




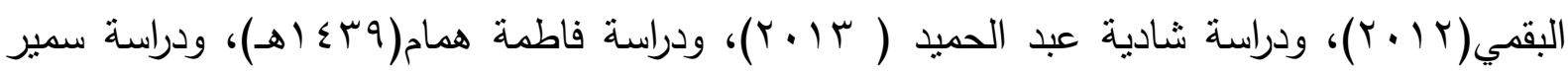

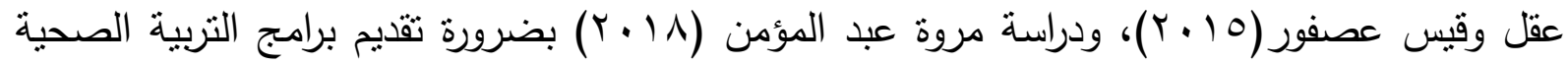
لتتمية ممارسة السلوك الصحي والوعي الصحي للأطفال بطرق تنتاسب وتتلاءم معهم، ويميل إليها الأطفال، وتجذب انتباههم، وتساعدهم على اكتساب المعارف والاتجاهات والسلوكيات الصحية السليمة. من خلال عمل زيارات ميدانية متعددة لعدد من روضات التربية الفكرية، لاحظت الباحثة ميل الأطفال الروضة ذوي الإعاقة العقلية البسيطة للقصص الني تحكى لهم، وانجذابهم لها، واستمتاعهم بها، وتقمصه لأبطالها، وتقليدهم لسلوكيات شخصياتها، كما نم الاطلاع على عدد من الأدبيات والدراسات

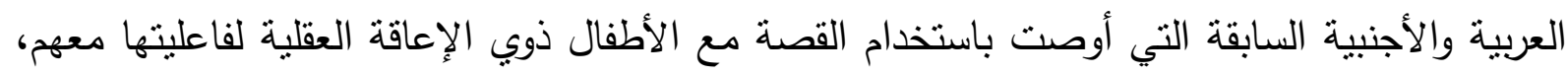

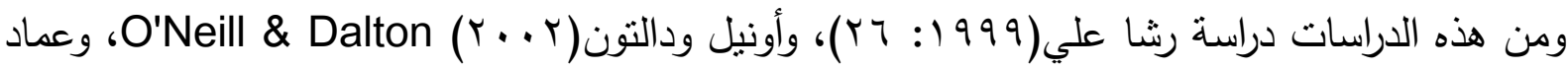

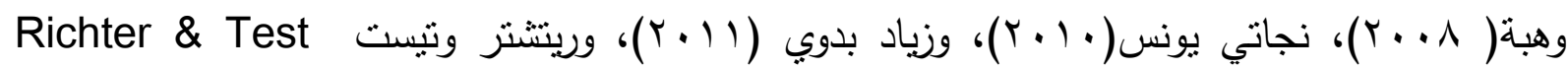

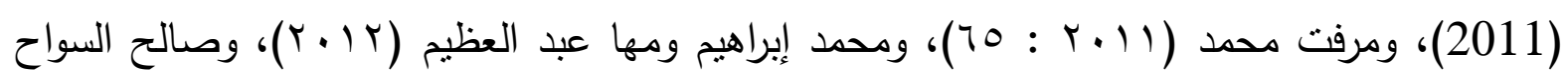

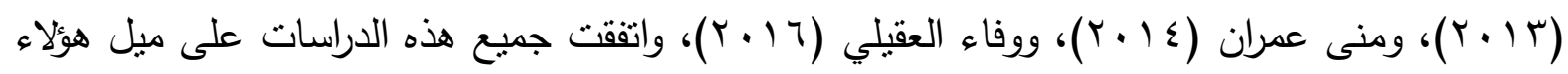

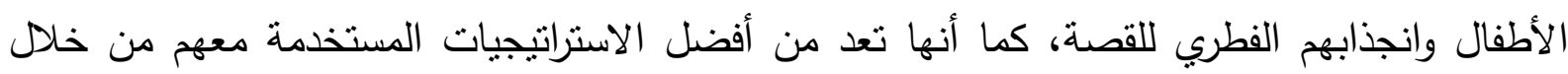

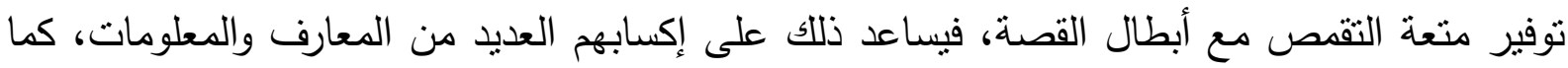
تسهم من خلال أحداثها في تكوين الاتجاهات الإيجابية نحو اكتساب السلوكيات المقبولة اجتماعيًا، كما

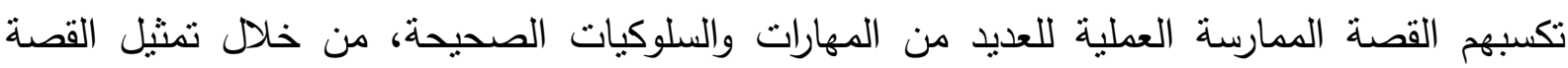
المقدمة لهم ومحاكاتها، بالإضافة إلى أنها تعدل السلوك الخطأ، وتقدم لهم القصة من خلال حبكتهات العهات

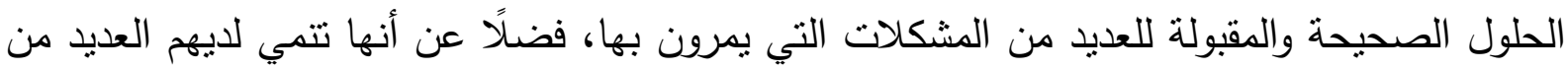
المهارات الحياتية اليومية التي يحتاجون إليها، ولم تجد الباحثة - في حدود علمها - دراسة عن فاعلية

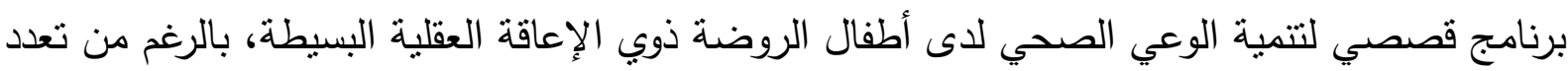
الدراسات التي اهتمت بدراسة القصة التي حصلت عليها؛ مما دعا لهذه الدراسة. في ضوء ما سبق استهلت الدراسة الحالية الإجابة عن السؤال الرئيس التالي: - ما فاعلية برنامج قصصي لتمية الوعي الصحي لدى أطفال الروضة ذوي الإعاقة العقلية البسيطة؟

\section{ويتفرع من هذا السؤال الأسئلة الفرعية الآتية:}

ا ـ ما أبعاد الوعي الصحي التي يحتاج أطفال الروضة ذوو الإعاقة العقلية البسيطة إلى تتميتها؟

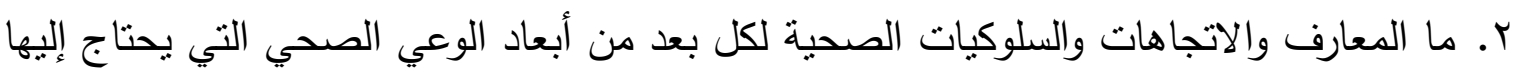
أطفال الروضة ذوي الإعاقة العقلية البسيطة لتتمية الوعي الصحي لايهج؟ 
r. ما البرنامج القصصي لتتمية الوعي الصحي لدى أطفال الروضة ذوي الإعاقة العقلية البسيطة؟ ع. ما فاعلية البرنامج القصصي لنتمبة الوعي الصحي بأبعاده لاى أطفال الروضة ذوي الإعاقة

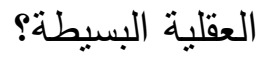

فروض الدراسة:

الفرض الأول: يوجد فرق دال إحصائيًا عند مستوى > 0.05 بين متوسطي درجات أطفال المجموعة

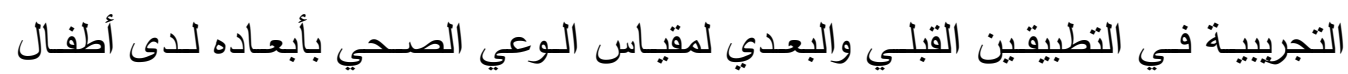
الروضة ذوي الإعاقة العقلية البسيطة لصالح التطبيق البعدي.

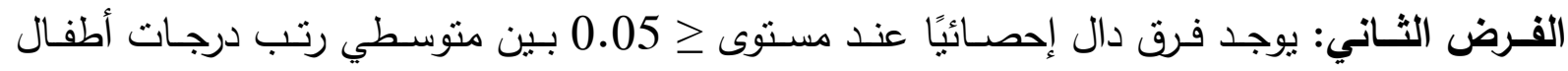

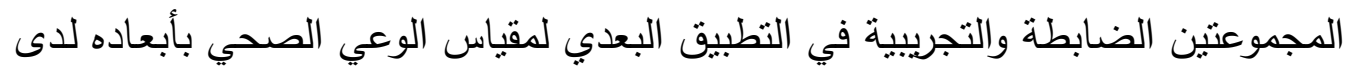
أطفال الروضة ذوبي الإعاقة العقلية البسيطة لصالح أطفال المجموعة التجريبية.

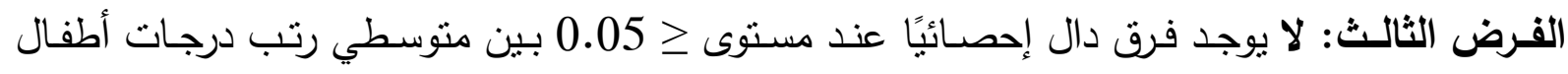

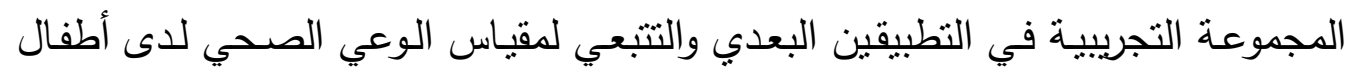
الروضة ذوي الإعاقة العقلية البسيطة.

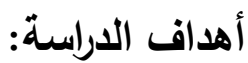

ا ـ تحديـد أبعـاد الـوعي الصـحي المناسـبة لأطفـال الروضــة ذوبي الإعاقـة العقليـة البسـبطة،

ويحتاجون تتميتها.

r. تحديد المعارف والاتجاهات والسلوكيات الصحية التي يحتاجها أطفال الروضة ذوبي الإعاقة العقلية البسيطة لتنمية الوعي الصحي لديهم.

r. إعداد برنـامج قصصي لتتميـة الوعي الصـحي لـى أطفـال الروضــة ذوبي الإعاقـة العقليـة البسيطة.

ع. التحقق مـن فاعليـة البرنـامج القصصـي لتتـيـة الوعي الصـحي لدى أطفال الروضــة ذوي الإعاقة العقلية البسيطة. أهمية الدراسة: وتتقسم أهمية الدراسة الحالية إلى: أولاً: الأهمية النظرية للاراسة، وهي: ا ـ تهتم بأطفال الروضة ذوي الإعاقة العقلية البسيطة. r. تسعى لتتمية الوعي الصحي لأطفال الروضة ذوبي الإعاقة العقلية البسيطة. r. تصمم برنامج لتتمية الوعي الصحي لأطفال الروضة ذوبة ذوبي الإعاقة العقلية البسيطة. ؛. تحديد معايير تصميم القصص المقدمة لأطفال الروضة ذوي الإعاقة العقلية البسيطة. 
ه. تحقق هذه الدراسة توصية العديد من الدراسات بتوظيف القصة مع الأطفال الروضة ذوي

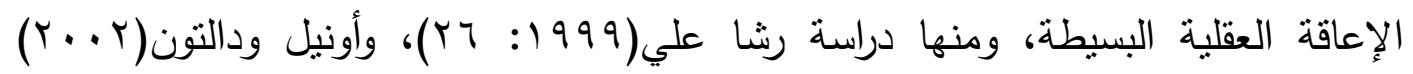
O'Neill \& Dalton

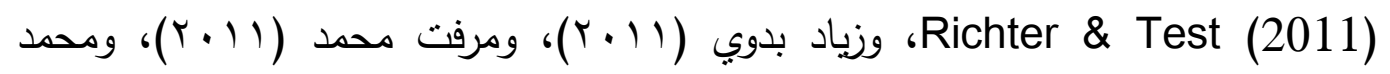

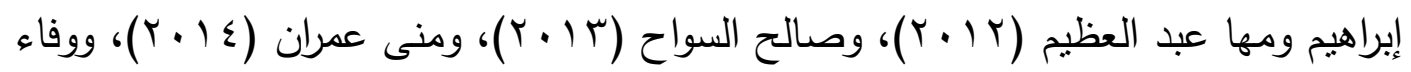

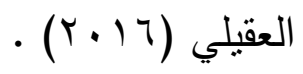

ثانياً: الأهمية التطبيقية للاراسة، وتتضح فيما يأتي: ا. تحقق الدراسة أهداف التربية الخاصة مع الأطفال ذوي الإعاقة العقلية البسيطة من خلال

$$
\text { تتمية الوعي الصحي لديهم. }
$$

r. تلبي الدراسة الحالية هدف من أهداف روضات ومدارس التربية الفكرية لمواجهة العديد من مشكلاتهم الصحية ومقاومتها من خلال تتمية الوعي الصحي لديهم. r. تقدم برنامجًا قصصيًا لتتمية الوعي الصحي لدى أطفال الروضة ذوي الإعاقة العقلية البسيطة.

ء. تساعد معلمات أطفال الروضة لتتمية الوعي الصحي لأطفال الروضة ذوي الإعاقة العقلية البسبطة. ه. قد يحد البرنامج المقدم من المشكلات الصحية التي يعاني منها أطفال الروضة ذوي الإعاقة العقلية البسيطة مع تقدم العمر • 7 7. تقيد الآباء والأمهات في المتابعة الصحية لأطفالهم ذوي الإعاقة العقلية البسيطة. V. تساعد الدراسة جميع المؤسسات التي تتعامل مع الأطفال ذوي الإعاقة العقلية لتتمية الوعي الصحي لهم. A. توظف القصة لتنمية الوعي الصحي لدى أطفال الروضة ذوي الإعاقة العقلية البسيطة. منهج الدراسة: استخدم في الدراسة الحالية المنهج الوصفي التحليلي عند إعداد كل من: الإطار النظري، والبرنامج القصصي، وأداة الدراسة، كما استخدمت الدراسة المنهج شبه التجربي ذي المجموعتين المجموعة التجريبية والمجموعة الضابطة مع القياس القبلي للمجموعنين ثم تطبيق البرنامج القصصي على أطفال المجموعة التجريبية، أما أطفال المجموعة الضابطة فلم يتعرضوا للبرنامج، ثم القياس البعدي للكثف عن فاعلية البرنامج القصصي (كمتغير مستقل)، لتتمية الوعي الصحي (كمتغير تابع) لاى أطفال الروضة ذوي الإعاقة العقلية البسيطة. 
يُعرف أطفال الروضة ذوي الإعاقة العقلية البسيطة إجرائيًا بأنهم أطفال يتراوح نسبة ذكاءهم من (

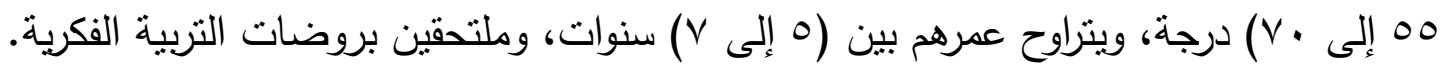
يُعرف البرنامج القصصي إجرائيًا بأنه مجموعة من القصص المقدمة لأطفال الروضة ذوي الإعاقة

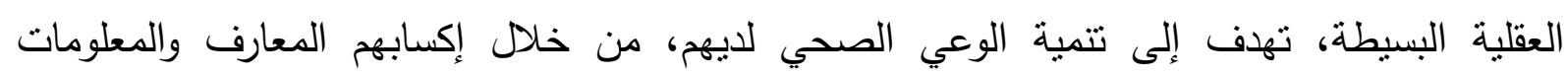

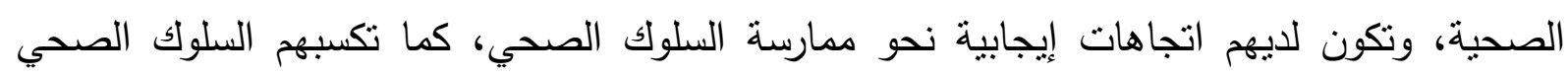
السليم. تُعرف القصة إجرائيًا بأنها مجموعة من الأحداث البسيطة المتعاقبة الثيقة التي تجذب انتباه الأطفال، ويتخلاها عقدة، ويجسدها عدد من الثخصيات، وتنتهي نهاية سعيدة عادلة، وتحقق لهم التسلية، والترفيه، والمتعة، لتتمية الوعي الصحي لأطفال الروضة ذوي الإنها لإعاقة العقلية البسيطة. يُعرف الوعي الصحي إجرائيًا بأنه إلمام أطفال الروضة ذوي الإعاقة العقلية البسيطة بالمعارف

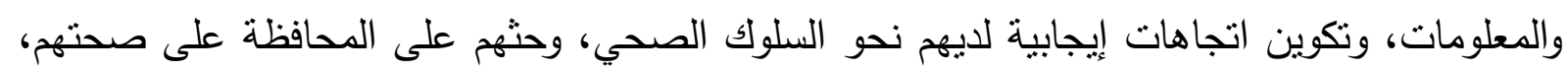
وتعويدهم على ممارسة السلوكيات الصحية السليمة. أدوات الاراسة :

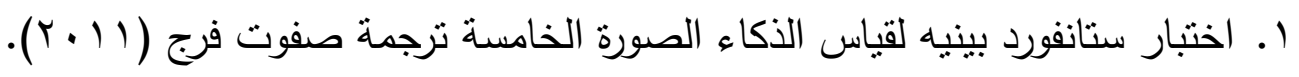
r. مقياس المستوى الاجتماعي والاقتصادي والثقافي للأسرة (محمد خليل، .... ب). r. مقياس الوعي الصحي لدى الأطفال الروضة ذوي الإعاقة العقلية(إعداد الباحثة). ـ. البرنامج القصصي (إعداد الباحثة).

محدات الاراسة: اقتصرت الدراسة الحالية على ما يأتي:

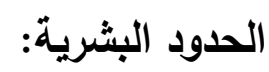

- - أطفال الروضة ذوبه الإعاقة العقلية البسيطة من سن م إلى V سنوات.

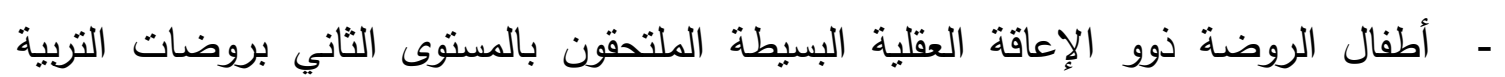
الفكرية (مدرسة الرمل الميري ومدرسة أحمد شوقي) بمحافظة الإسكندرية. الددود الموضوعية: - تمية الوعي الصحي لدى أطفال الروضة ذوي الإعاقة العقلية البسيطة. 
الحدود الزمانية:

- طُُق برنامج الدراسة على أطفال الروضة ذوي الإعاقة العقلية البسيطة، الملتحقين بالمستوى الثاني لروضات مدارس التربية الفكرية بمحافظة الإسكندرية في الفصل الدراسي الأول من العام

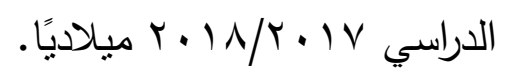

الحدود المكانية:

- تم التطبيق بروضات مدارس التربية الفكرية( الرمل الميري، وأحمد شوقي ) بمحافظة الإسكندرية.

الإطار النظري للاراسة:

الإطار النظري لهذه الدراسة يتكون من محورين، وهما: المحور الأول بتتاول برامج التربية الصحية لتتمية الوعي الصحي، و يتتاول المحور الثاني: القصة لأطفال الروضة ذوي الإعاقة العقلية البسيطة.

\section{المحور الأول: برامح التربية الصحية:}

إن مجال ذوي الاحتياجات الخاصة من أهم المجالات التي تهتم بها جميع دول العالم في الوقت الحالي؛ لأن الاهتمام بهم في أبي دولة يحقق التتمية الاجتماعية، والاقتصادية لها، وأن تقديم الخدمات الصحية، والتربوية، والاجتماعية للأفراد ذوي الاحتياجات الخاصة يعد من أهم المعايير التي تدل على دلى تقدم أي دولة، وبعاني الأطفال ذوو الإعاقة العقلية من العديد من المشكلات الصحية، سواء بسبب

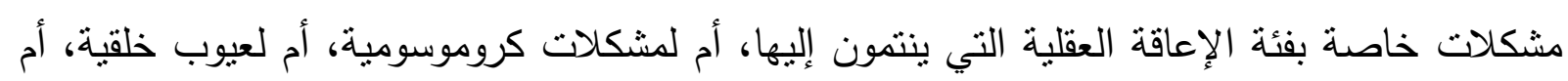
لانتمائهم لأحد المتلازمات، أم لإصابتهم بأمراض غربية نادرة، لذلك يعد هؤلاء الأطفال أكثر فئات ذوبي الاحتياجات الخاصة حاجةً لتنمية الوعي الصحي لديهج، ويجب توفير الخدمات الصحية لهم منذ اكتثافهم، وكما يجب توفير لهح برامج تهتم بتتمية الوعي الصحي لديهم منذ التحاقهم بروضات التربية

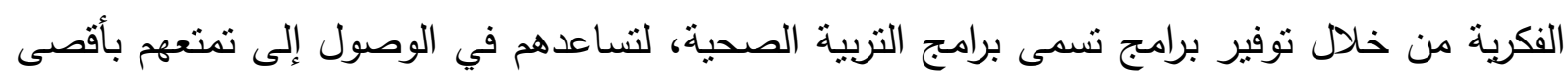
درجات الصحة التي يمكن أن يصلوا إلبها.

\section{1 - 1 - تعريفات الصحة، وبرامج التربية الصحية، واللوعي الصحي ستعرض فيما يأتي:}

\section{1-1-1 1- تعرة تعريفات، وهي:}

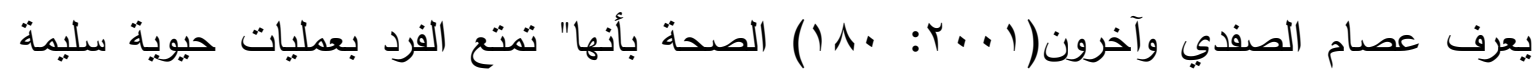
لوظائف الجسم، والخلو من العيوب، والتشوهات البدنية، والتمتع باللياقة البدنية العامة، والقوام السليم؛ ليتمكن من العمل، والإنتاج، وأداء المهام التي توكل إليه بصورة مناسبة". 


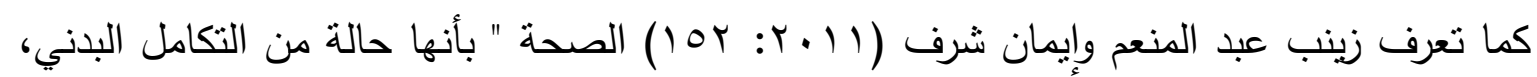

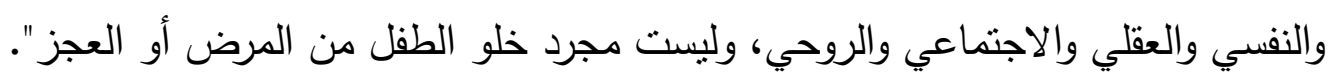

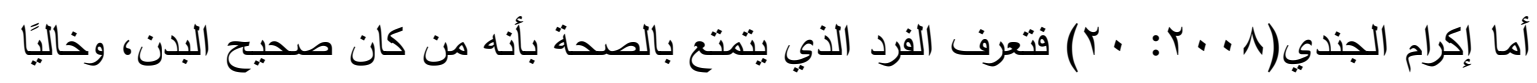

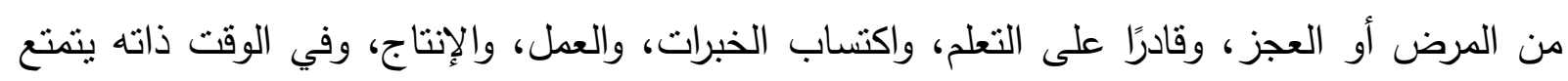

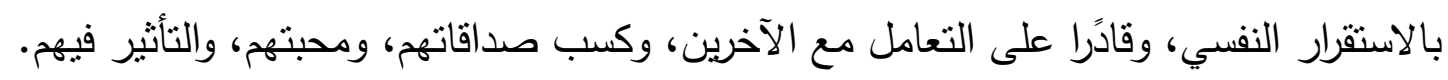

\section{: Health Education Program -1-1- تعريفات برامج التربية الصحية}

يعرف ماهوني وأولسين Mahoney \& Olsen (1993:35 برامج التربية الصحية بأنها عملية تقديم خبرات تعليمية متعددة بغرض التأثير الجيد في عادات الصحية للطفل، وسلوكه، واتجاهاته نحوها،

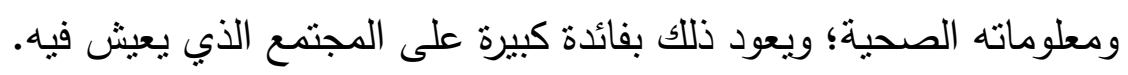

كما يعرف جيلبيرت وآخرون (2000:84) albert ,et al التربية الصحية الددرسية بأنها مجموعة من الخبرات التعليمية، والحقائق، والمعلومات الصحية التي تقدم للأطفال، من أجل إكسابهم السلوك الصحي.

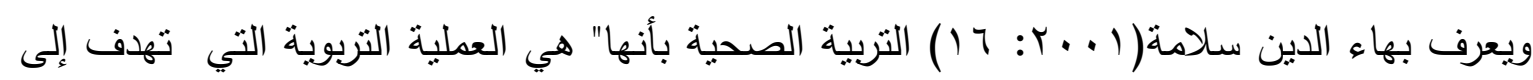

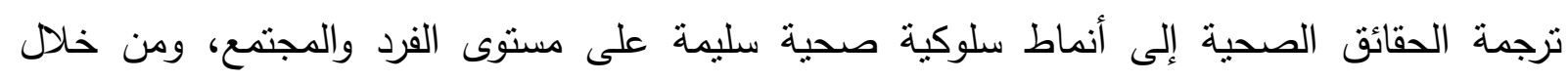

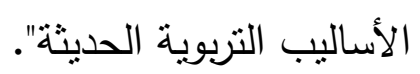

ويعرف محمد عبد المتوكل (r . . ا التربية الصحية بأنها" مجموعة من الخبرات التعليمية التي تعمل

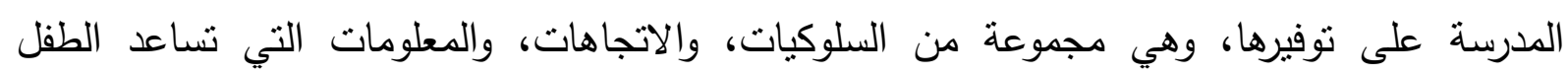
لاكتساب ما يجب أن يتعلمه، ويفطله، ويقدره الطفل تجاه الصحة".

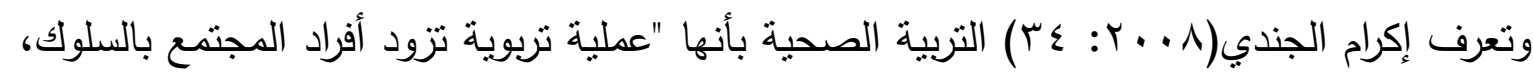

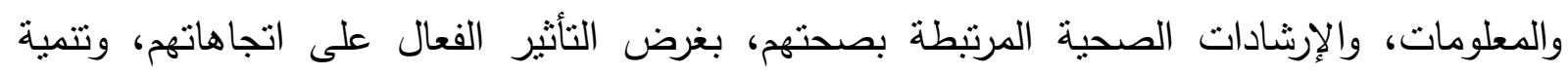

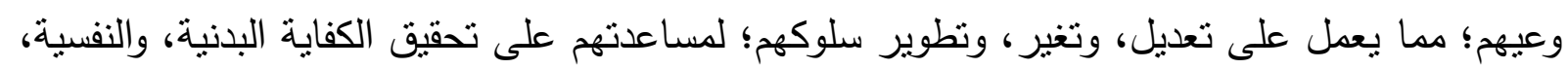

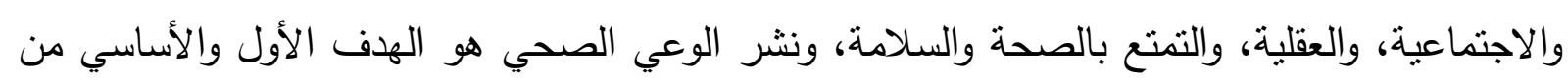
أهداف التربية الصحية.

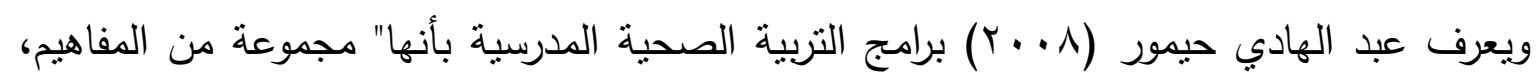

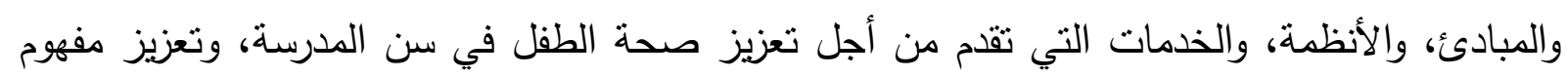

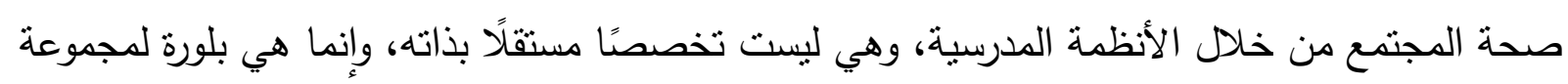

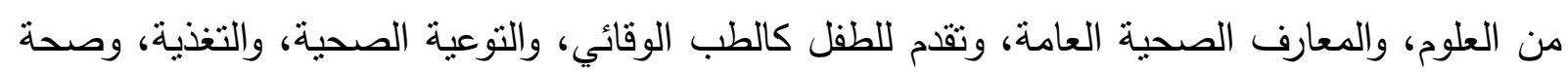

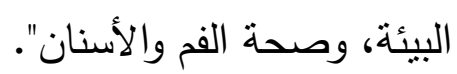




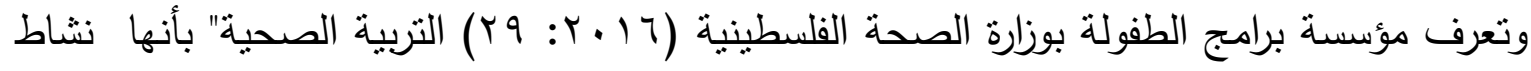

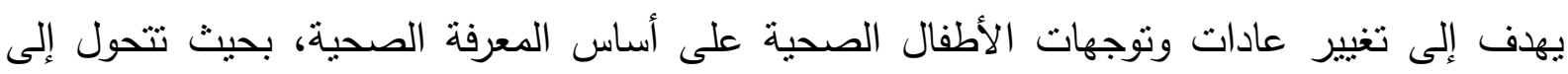
أنماط صحية تعزز صحته، وتضمن نمائه السليخ".

ويتضح من العرض السابق أن برامج التربية الصحية :

- - عملية تربوية لها أهداف تسعى إليها. - - ميتكون من مجموعة من الخبرات والأنشطة.

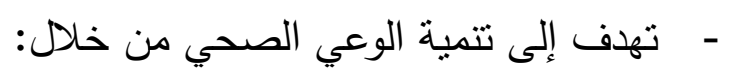
إكساب معارف ومعلومات صحية. توكوين الاتجاهات الإيجابية نحو ممارسة السلوك الصحي. إكساب ممارسة السلوك الصحي في المواقف الحياتية الدختلفة. - - تعديل السلوك الصحي الخطأ. - أن لها فائدة كبيرة على المجتمع من خلال التمتع بالصحة والسلامة. - تتمي القدرة على الوقاية من الأمراض المنتشرة.

يُعرف البرنامج القصصي اجرائيًا بأنه مجموعة من القصص المقدمة لأطفال الروضة ذوب الإعاقة

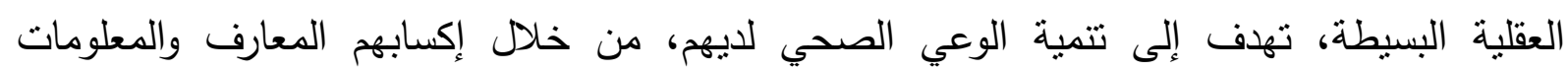

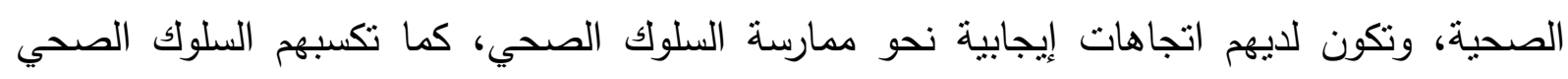

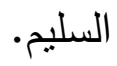

\section{- - 1-r- الوعي الصحي Health Awareness تعريفات متعددة منها:}

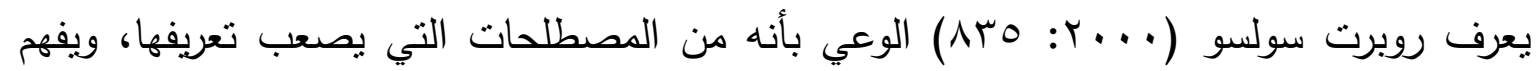

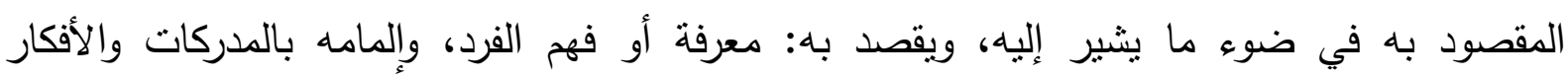
والمشاعر.

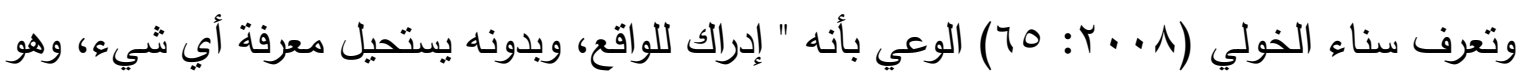
الحس الحاصل للفكر بخصوص حالاته وأفعاله". ولتعريف الوعي الصحي عدة تعريفات، ومنها ما يأتي:

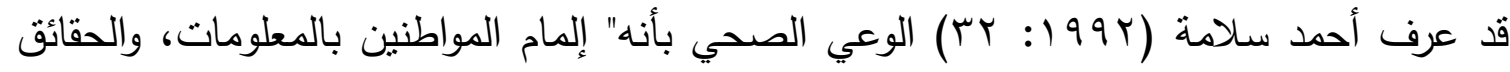

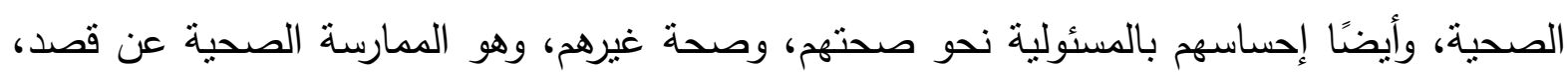
نتنجة الفهم والإقناع، وتحول كل الممارسات الصحية إلى عادات تمارس بلا شعور أو تفكير". 
يعرف أحمد اللقاني وعلى الجمل(1999 1: VY) المقصود بالوعي الصحي" بإعطاء الفرد شحنة معرفية

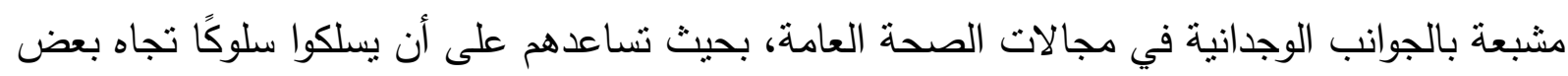

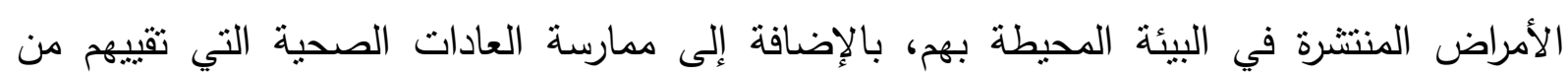

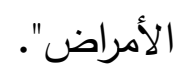

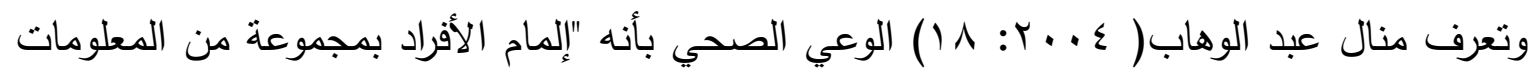

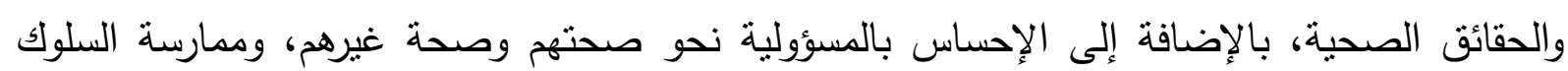

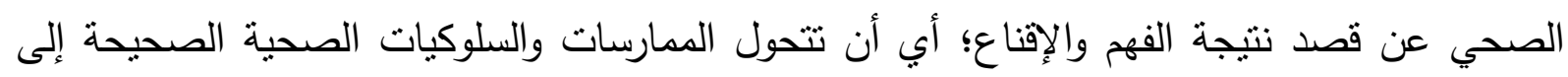
عادات تمارس بلا شعور أو تفكير".

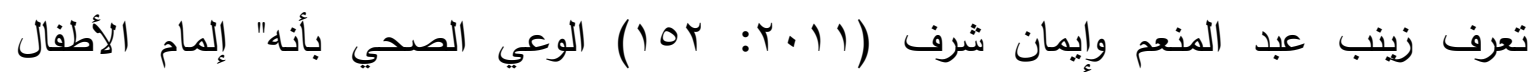
بالمعلومات، والحقائق الصحية، وإحساسهم بالمسؤولية نحو صحتهم، وصحة غيرهم". من خلال التعريفات السابقة يتضح ما يأتي : - أن الوعي الصحي يتم من خلال إلمام الطفل بالمعلومات، والمعارف الخاصة بالسلوك

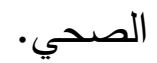

- الوعي الصحي يكون لدي الطفل اتجاهات إيجابية نحو ممارسة السلوك الصحي. - يهدف إلى تكوين لدي الطفل الثعور بالمسؤولية تجاه صحته، وأهية الحفاظ عليها. - الوعي الصحي يسعى إلى ممارسة الطفل السلوك الصحي ليصبح عادات آلية لا شعورية لدى الطفل.

يُعرف الوعي الصحي إجرائيًا بأنه إلمام أطفال الروضة ذوي الإعاقة العقلية البسيطة بالمعارف

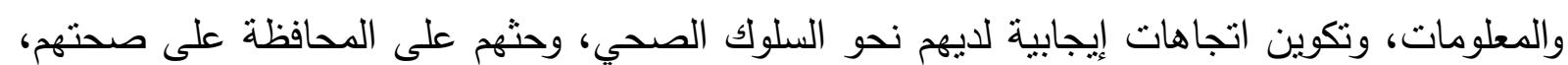
وتعويدهم على ممارسة السلوكيات الصحية السليمة.

1-r- الحاجة إلى توفير برامج التربية الصحية لأطفال الروضة ذوي الإعاقة العقلية البسيطة : أن رعاية وعناية الطفل تعد علمًا وفنًا في وقت نفسه، ولذا لا تتزك هذه العناية والرعاية لجهود الآباء

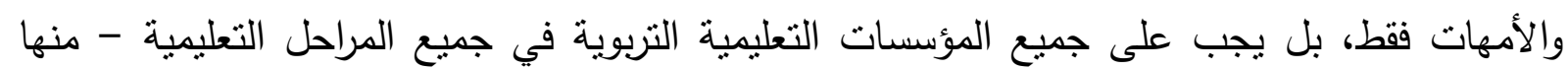

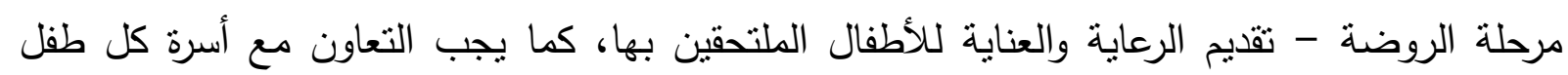
لتحقيق ذلك، من خلال توفير برامج التربية الصحية المناسبة للطفل، ويعد ذلك من أهم الواجبات المكلفة

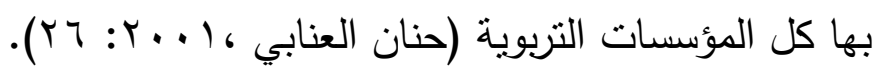

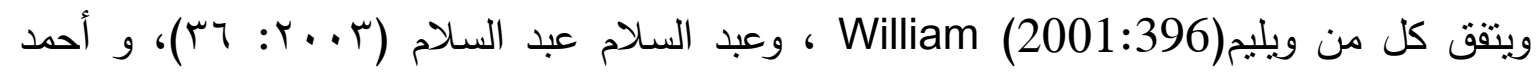

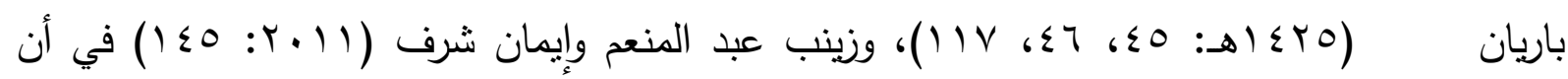


انتشار الأمراض في أب دولة يرجع إلى عدم وعي أفرادها بالسلوك الصحي السليم، وعدم تقديم طرق

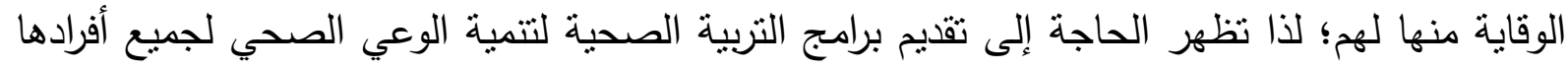

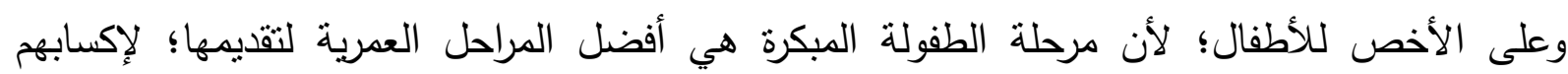

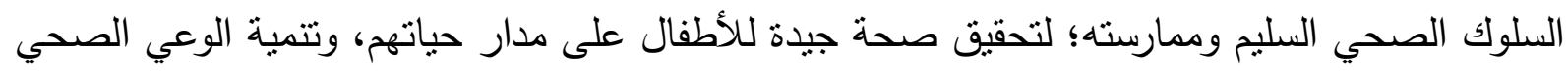

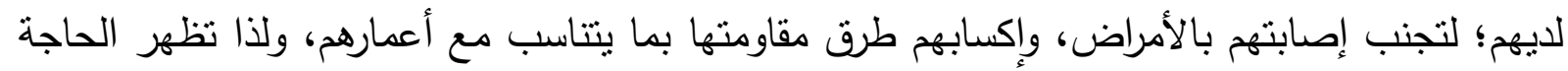

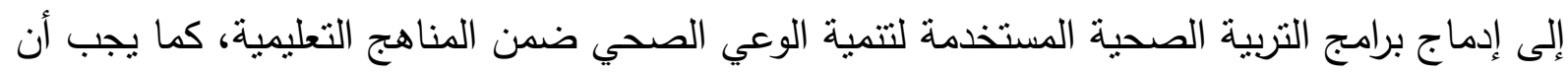

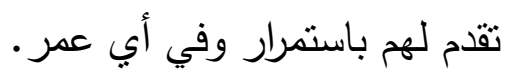

كما يؤكد محد السيد وآخرون (r . . ץ: ؛ ،ه ) على ضرورة توفير برامج التربية الصحية، والحاجة

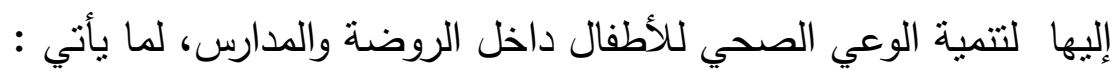
1. ضعف وقصور المعلومات الصحية للأطفال. r. أن العادات الصحية التي توفرها الروضة والمدارس لأطفالها تؤثر على صحة الألفال الطفال

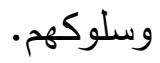
r. أن إهمال تقديم برامج التربية الصحية للأطفال، وعدم تتمية الوعي الصحي لديهم يكون

$$
\text { السبب في إصابتهم بالعديد من الأمراض. باض. الهمان }
$$

ع. تفسير مرض الأطفال نتيجة للإهمال الصحي، وليس لأسباب غير معروفة، منل : الحسد.

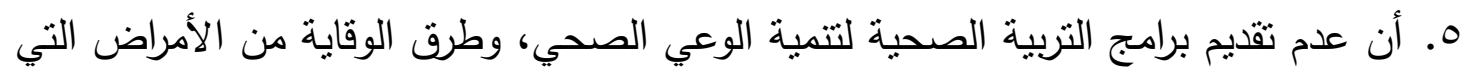
قد نواجه الأطفال يتسبب في انتشار العديد من الأمراض المعدية فيما بينهم. كما أكدت نتائج العديد من الدراسات على الحاجة إلى توفير برامج التربية الصحية منذ مرحلة

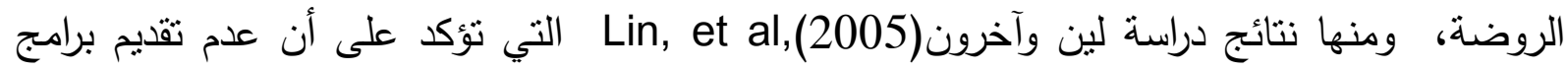

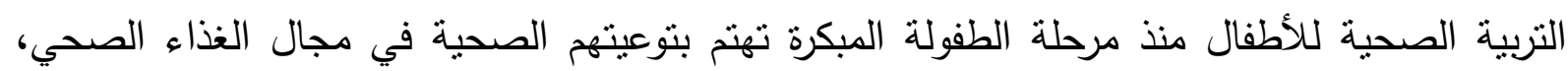

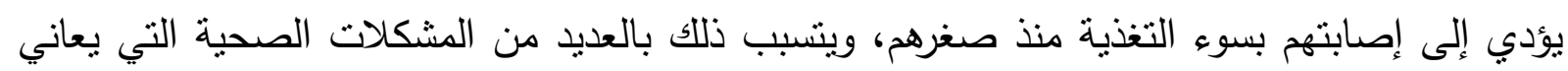
منها الطفل، ومنها القصور في جميع جوانب الطفل الجسمية، والمعرفية؛ مما يؤثز على الأداء الدراسي لئي

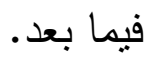

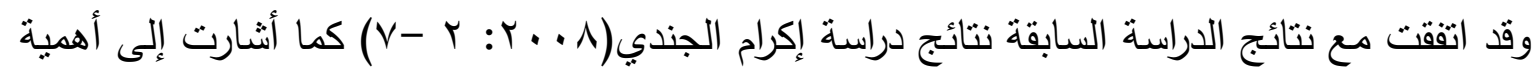

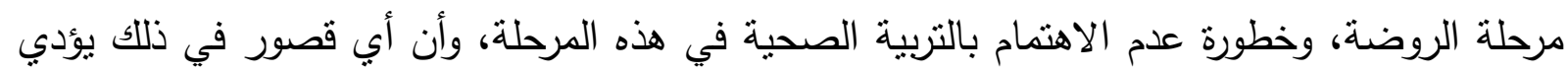

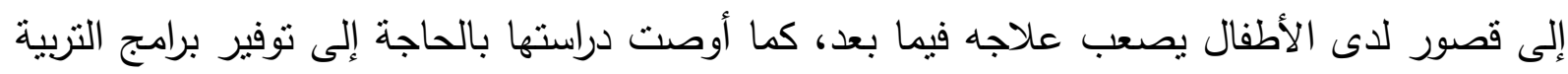

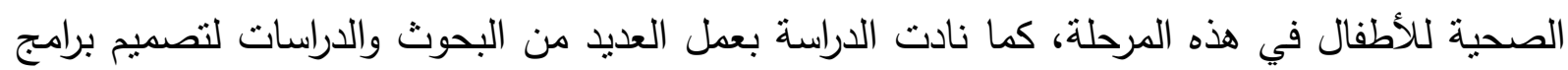

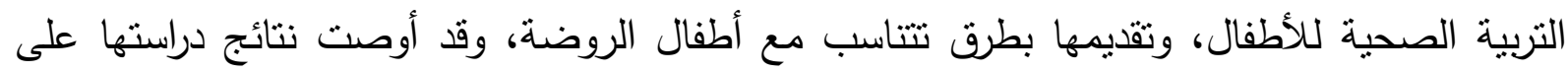


ضرورة تقديم برامج التربية الصحية لأطفال الروضة لتتمية الوعي الصحي لايهم والحاجة إليها، وذلك لما يأني :

ا. جاءت نتائج الدراسة الاستطلاعية لها على عدد . .1 طفل وطفلة في بعض الروضات

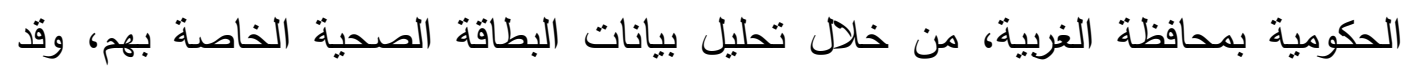
جاءت النتائج بالنسب الآتية من العينة الاستطلاعية:

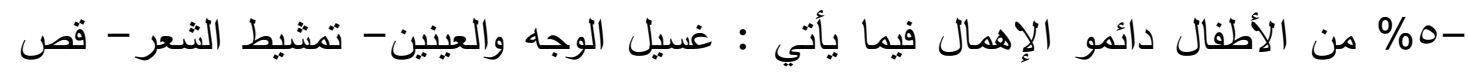
الأظفار ( الأظافر ) - تتظيف الأنف والأذن. - ( \% من الأطفال يتعرضون للحوادث المختلفة، ومنها :كدمات، وكسور، واختتاق، وتسمم من طعام ملوث، وجروح. - ـ ( من الأطفال لديهم عادات غذائية سيئة، ومنها :تتاول حلويات بشراهة، وعدم تتاول وجبة الإقطار ، وتتاول وجبات ضارة. -10\% من الأطفال مصابون ببعض الأمراض الجلدية، أو يعانون من التهابات في الحلق واللوزنين والأذن.

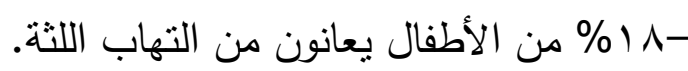
\% \% من الأطفال يعانون من تسوس الأسنان. r. قصور الوعي الصحي بالتغذية السليمة للأطفال؛ مما يؤدي إلى مشكلات تصاحبهم عبر

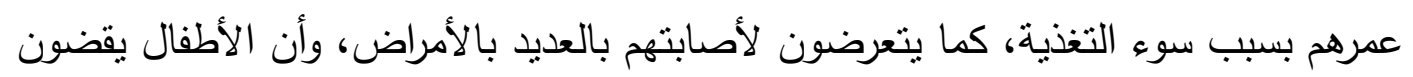

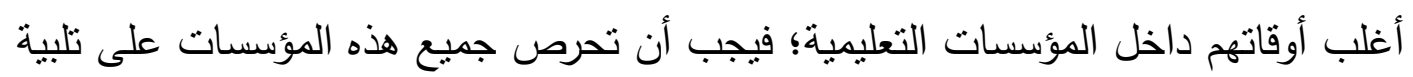
جميع حقوق الطفل(الصحية، والجسمية، والنفسية)، وهذا كله توفره برامج التربية الصحية

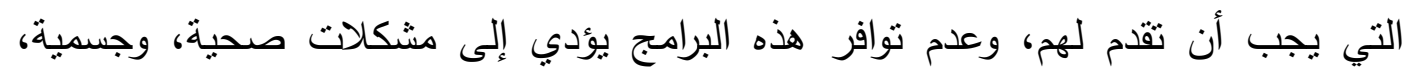

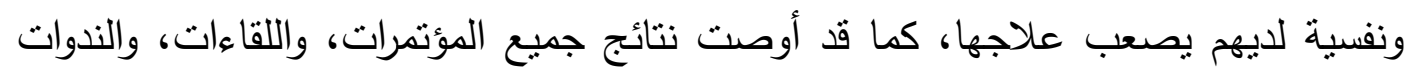

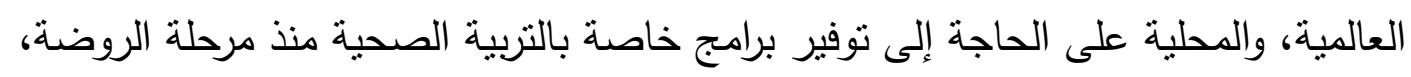

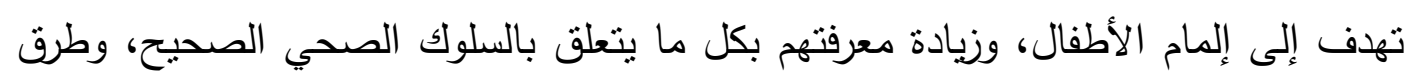
ممارسته.

r. ارتفاع نسبة انتثار الأمراض المعدية بين الأطفال التي تتراوح أعمارهم بين (0 إلىع ()

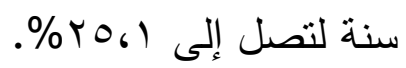


وقد أوصت العديد من الدراسات بالحاجة إلى توفير برامج تربية صحية خاصة لتمية الوعي الصحي بالأطفال العاديين الذين لديهم ظروف مرضية خاصة، ومنها دراسة والديرس وآخرين ( Walders ,et al, 2004) التي هدفت إلى تصميم برنامج للتخخل المبكر بعنوان Head Start لتوعية الصحية لأطفال

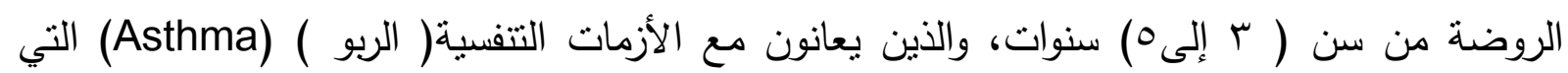
يتعرض لها الأطفال في هذا السن، وقد أوصت الدراسة بضرورة توفير برامج التذخل المبكر للتربية الصحية تقدم لأطفال الروضة؛ لتتمية وعيهم الصحي، وللتدريب على كيفية مواجهة مشكلاتهم الصحية. وقد اهتمت دراسة تاراس وبوتس- داتيما ( Taras \& Potts-Datema 2005) بالمشكلات الصحية المزمنة التي يعاني منها الأطفال، ومنها: الأزمات التتفية، واضطراب عضلة القلب، واضطراب نسبة السكر في الدم، والصرع، والسرطان، والأمراض المعوية، ولهذا تأثير كبير على دوامهم، وتحصيلهم، وهيه وأدائهر في الروضات والمدارس الملتحقين بها، وقد أوصت الدراسة باحتياجه لتوفير برامج للتربية الصحية لمعاونة معلميهم على إكسابهم السلوك الصحي، وتتمية الوعي الصحي السليم من خلالها. وأوضحت نتائج دراسة بيشوب وبواج ( Bishop\& Boag والتي اهتمت باتجاهات المعلمين والمعلمات نحو الأطفال الذين يعانون من الصرع(Epilepsy)، وتتمية معارفهم ومعلوماتهم عن بـ هذا المرض بضرورة توفير برامج التربية صحية لهم لزيادة وعيهم الصحي؛ لكثرة تعرضهم للعديد من الأمراض والمشكلات الصحية الناتجة عن الصرع.

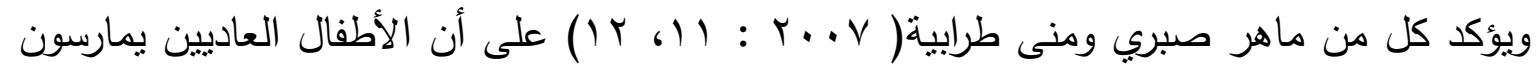
العديد من السلوكيات الخطأ صحيًا على الرغم من قلة مشكلاتهم الصحية التي يعانون منها، وسلامة حواسهم، ولكن بمقارنة المشكلات الصحية التي يعاني منها الأطفال العاديين بالمشكلات الصحية التي يعاني منها الأطفال ذوي الاحتياجات الخاصة نجد أن الأطفال ذوي الاحتياجات الخاصة يحتاجون إلى دئ دئ مزيد من الجهد والاهتمام في توفير برامج التربية الصحية لتعدد مشكلاتهم الصحية، وتعقدها، ولتتمية الوعي الصحي لديهم.

وكما قد أكد أكير وآخرون Akker ,et al,2006) على أن جميع الأطفال ذوي الاحتياجات الخاصة بفئاتها المختلفة يعانون من المشكلات الصحية خاصة بانتمائهم للفئات ذوي الاحتياجات الخاصة، بالإضافة إلى المشكلات الصحية الأخرى يعانون منها، مثل: أمراض القلب، وسرعة العدوى بالأمراض المنتشرة المعدية، ومشكلات نمائية كاضطرابات في النمو، وأمراض أخرى أكثر من التي يعانون منها الأطفال العاديين.

وقد نادت دراسة ميكهيرجي وآخرين (2000), Mukherjee ,et al بحاجة الأطفال ذوي الإعاقة العقلية لتتمية وعيهم الصحي ببرامج الرعاية والتربية الصحية، وأنهم أكثر فئات تحتاج لتوفير هذه البرامج 
على مدى حياتهم، لما لها تأثير كبير على دعمه الصحي، والاجتماعي، والنفسي في حياتهم منذ الصغر ، وفيما بعد مع كبر سنهم.

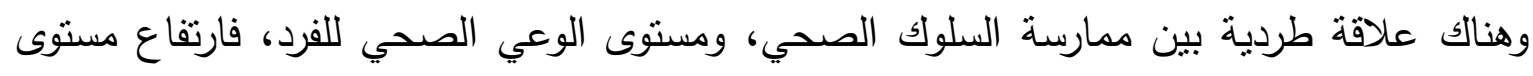
الوعي الصحي للفرد يؤدي إلى ارتفاع ممارسة السلوك الصحي لديه، وأكثر الفئات في المجتمع احتياجًا

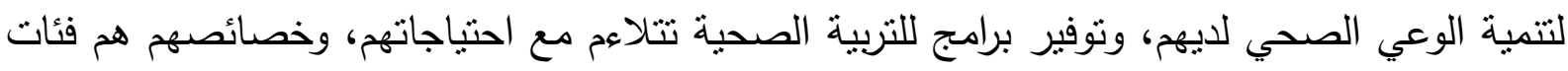

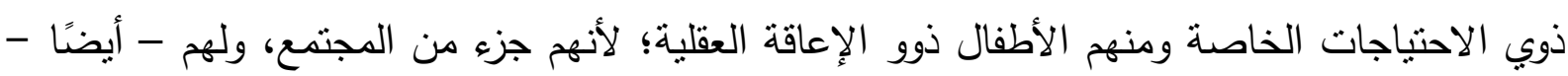

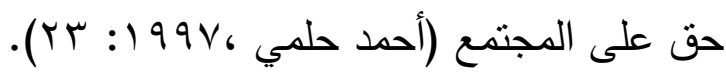

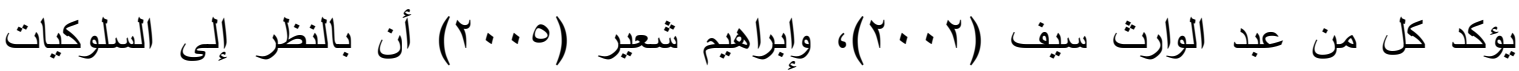
الصحية التي تقدم للأطفال ذوي الاحتياجات الخاصة نجدها سطحية، وفقيرة، ولا تلبي احتياجاتهم ومطالبهم، وقد أوصى كل منهم بضرورة توفير برامج تربية صحية خاصة بالأطفال ذوي الاحتياجات

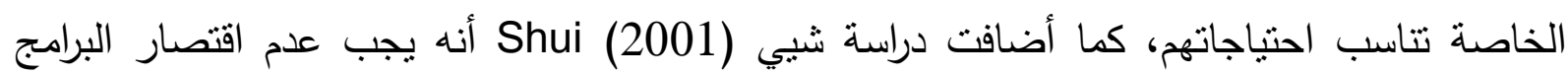

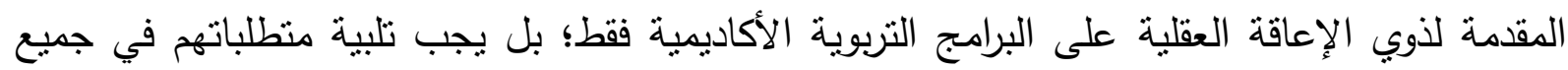

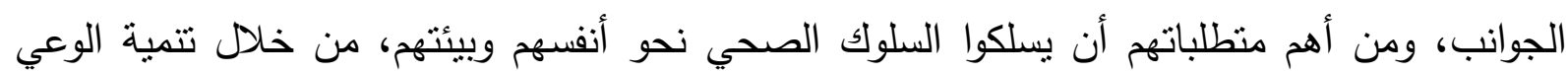
الصحي لديهم، ولتحقيق ذلك يجب نوفير برامج التربية الصحية لمعاناتهم من العديد من المشكلات الصحية لقصور الوعي الصحي لديهم.

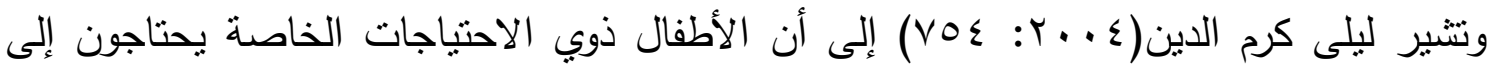

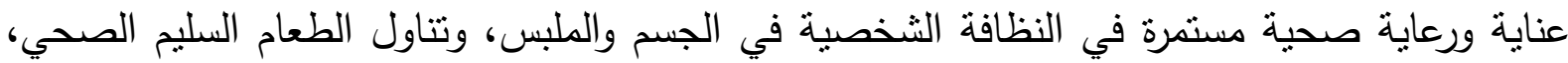

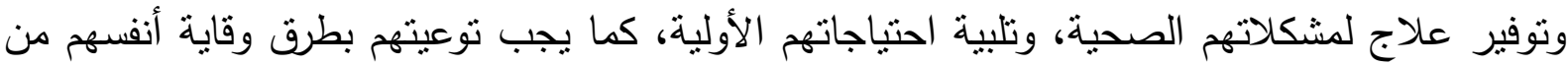

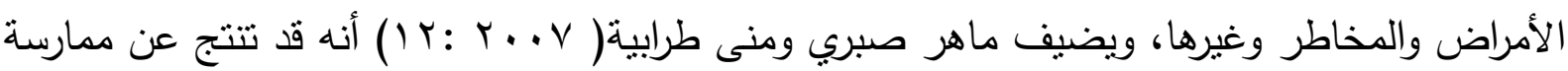
الأطفال ذوي الاحتياجات الخاصة للسلوكيات الخطأ صحيًا العديد من الأمراض الخطيرة، منل : مرض واضل الالتهاب الكبدي الوبائي، ولذا يجب تتمية الوعي الصحي من خلال برامج التربية الصحية الخاصة لهؤلاء

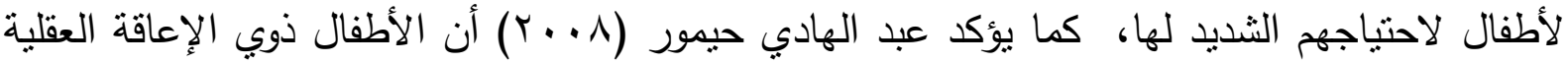

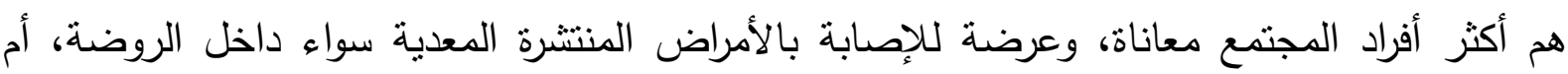

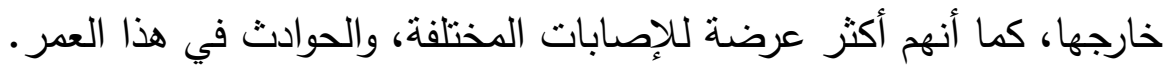

ويشير بوسش ورينجدهال (2001) Bosch\& Ringdahl إلى أنه من خلال دراسة لتحليل المشكلات السلوكية لدى الأطفال ذوبي الإعاقة العقلية، وجد أنهم يعانون من العديد من مظاهر سلوك

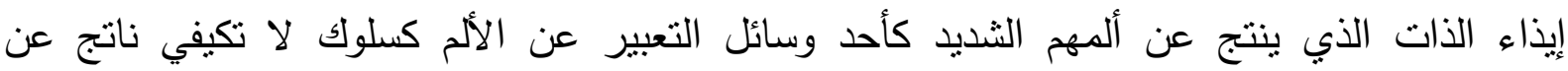

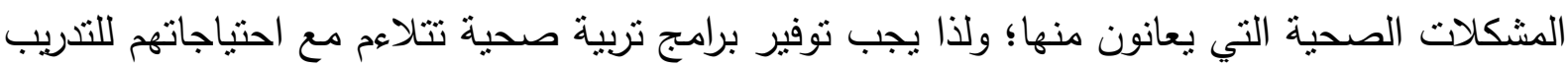

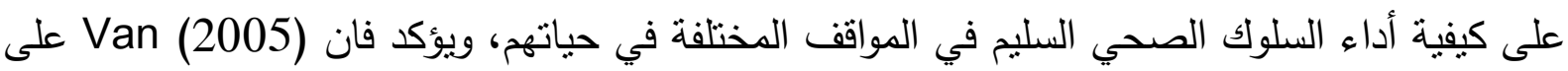


أن احتياج الأطفال ذوي الإعاقة العقلية في الدول النامية إلى توفير برامج التربية الصحية؛ لأنهم يعانون

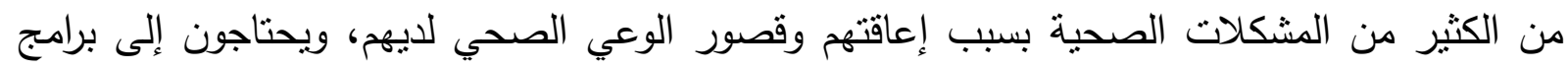
نزبية صحية.

وقد استهدفت دراسة عقلة ربابعة (ع . . r) إلى تحديد مشكلات أمراض الفم والأسنان الني يعاني منها الأطفال ذوي الإعاقة العقلية البسيطة، من خلال عينة من الأطفال ذوي الإعاقة العقلية بلغ عددهم

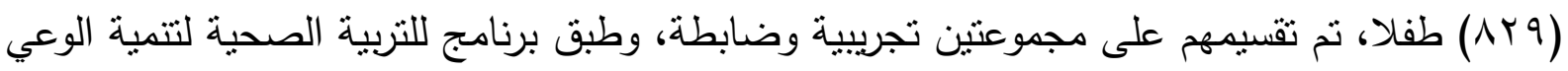

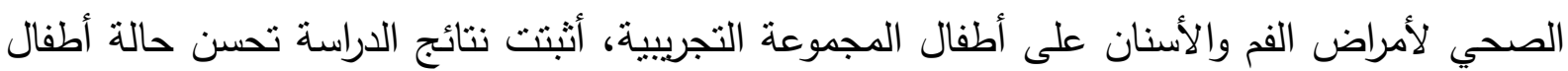

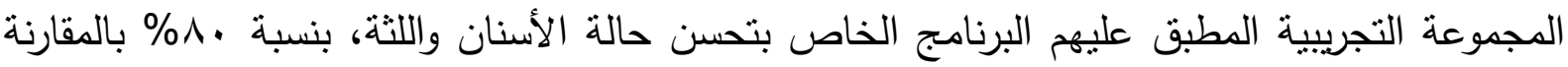
بأطفال المجموعة الضابطة الذين لم يطبق عليهم البرنامج، وأوصت الدراسة بضرورة نوفير برامج للتربية

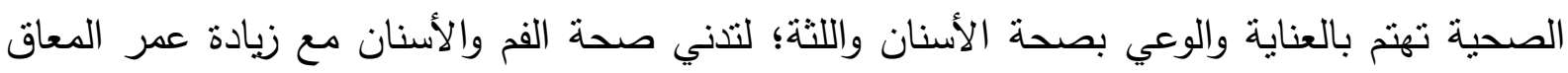
عقليًا.

كما جاءت نتائج دراسة وانج وآخرين Wang,et al,2006) التي هدفت إلى دراسة لبعض حالات الأطفال ذوي الإعاقة العقلية في تايوان، وقد توصلت الدراسة أن لهؤلاء الأطفال مشكلات صحية العية عديدة

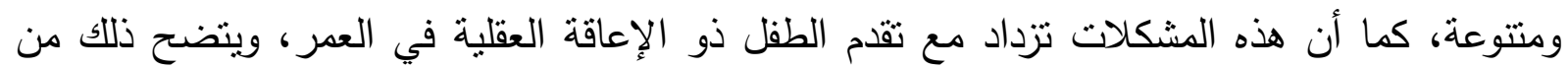

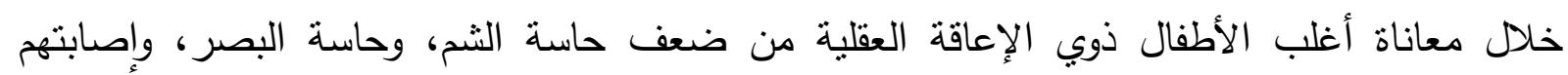

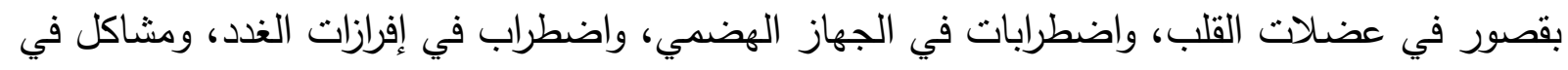

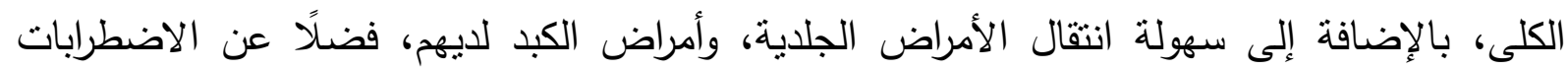

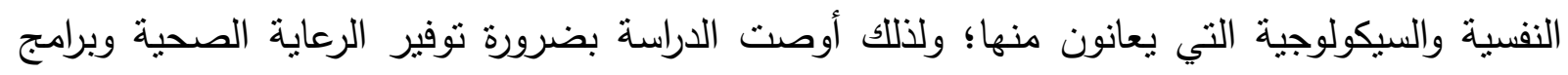
التربية الصحية لذوي الإعاقة العقلية منذ بداية اكتثاف الإعاقة وفي مرحلة الطفولة المبكرة لديهم لحاجتهم الثنديدة لذلك، ولتقليل مشكلاتهم الصحية مع كبر سنهم.

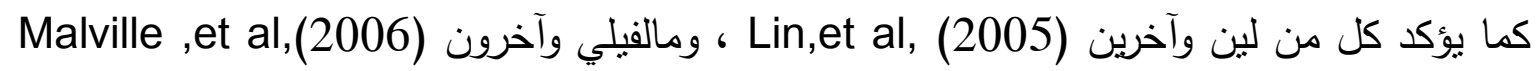

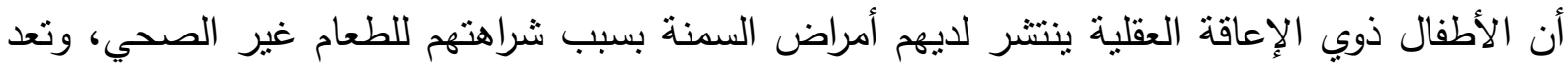

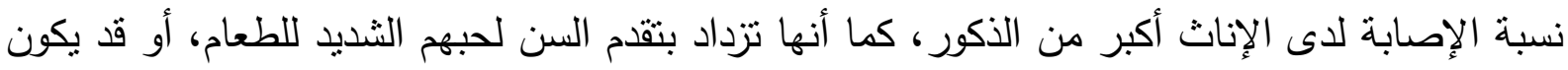

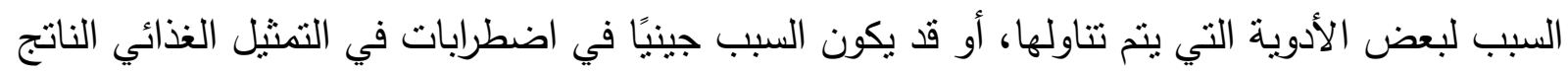

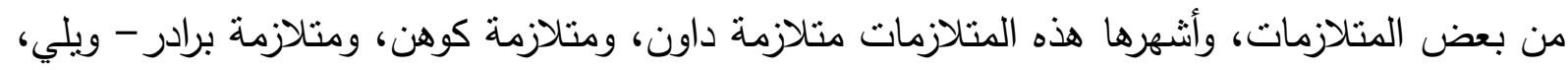

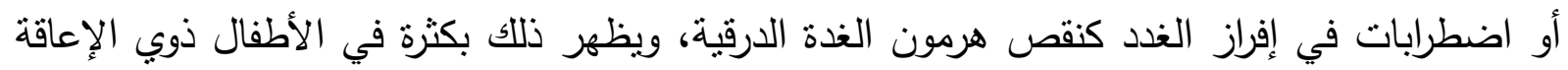
العقلية البسيطة، أما الأطفال ذوي الإعاقة الثديدة فإن معظمه يعانون من مشكلات في البلع ومضن

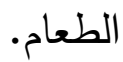


ويؤكد كوبر وآخرون (2006), من خلال دراسة طبق فيها برنامج للتربية الصحية

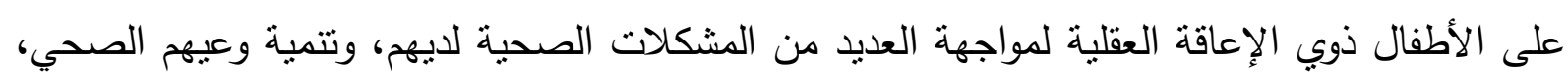

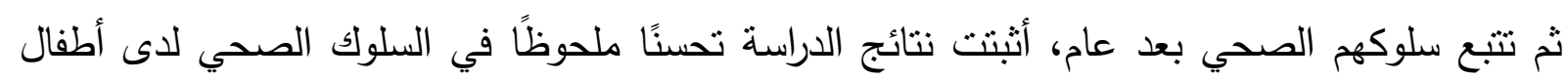
المجموعة التجريبية واهتمامهم، وحرصهم على أداء السلوكيات السليمة الصحيحة، مقارنةً بسلوك أطفال

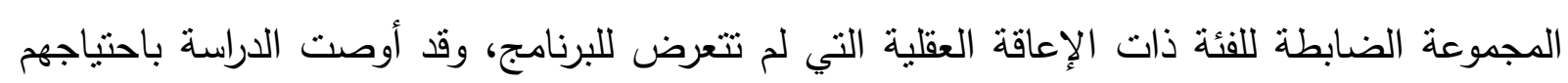

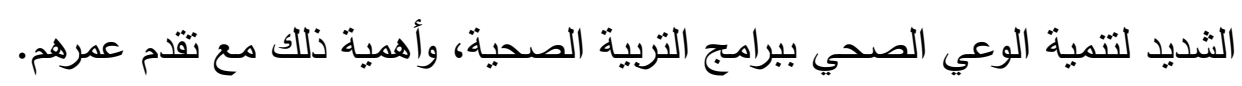

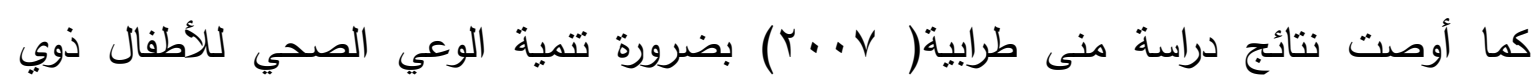

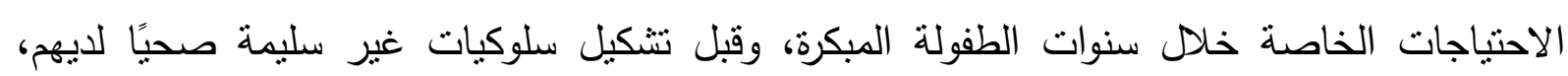

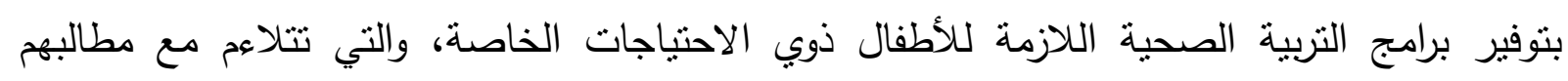

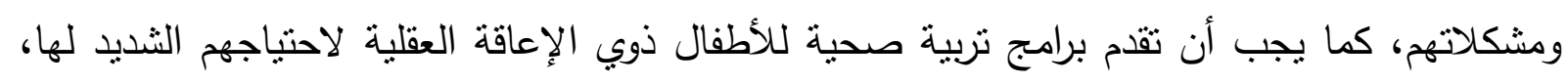
كما يجب إعداد المعلمين والمعلمات لتقديمها للأطفال.

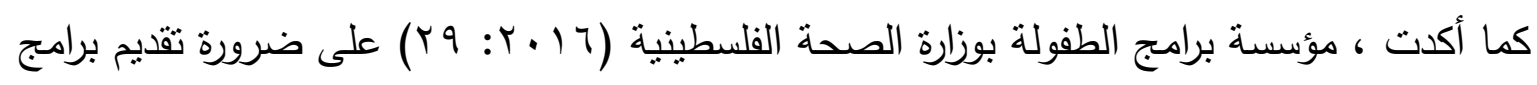
التربية الصحية للأطفال ذوي الاحتباجات الخاصة المعرضين لخطر الحوادث والأمراض، ولإكسابهم مهارات أداء السلوك الصحي السليم. لمطلئ. ويتضح من خلال العرض السابق توصية الدراسات والبحوث السابقة بتوفير برامج التربية الصحية

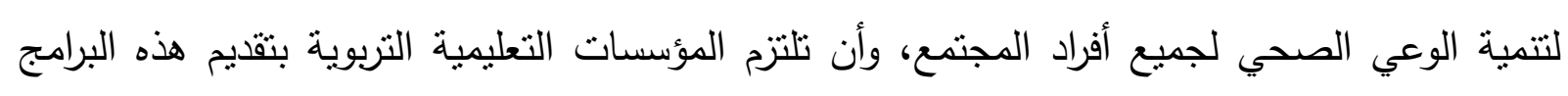

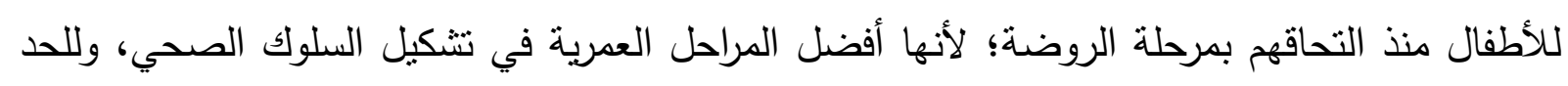

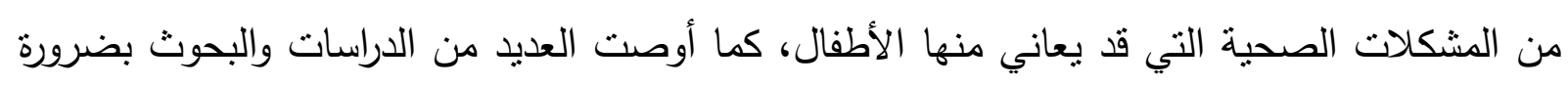

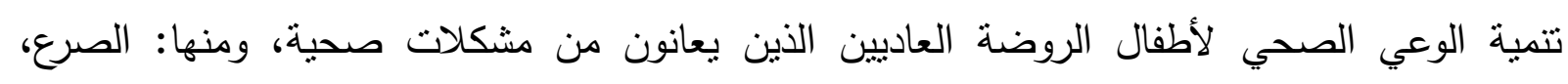

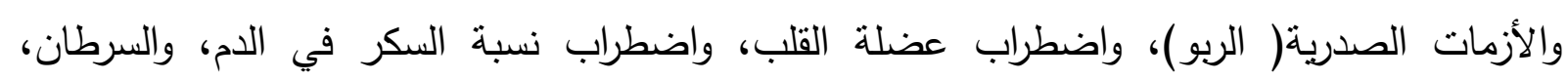

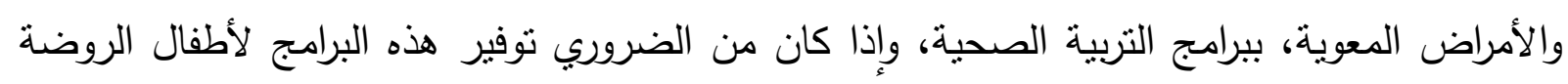

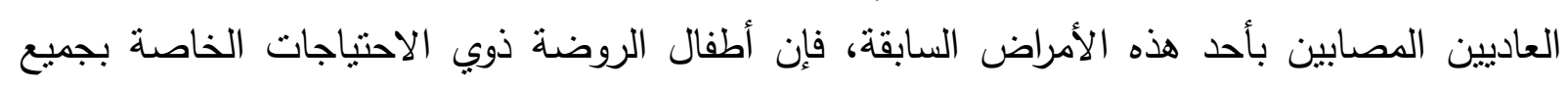

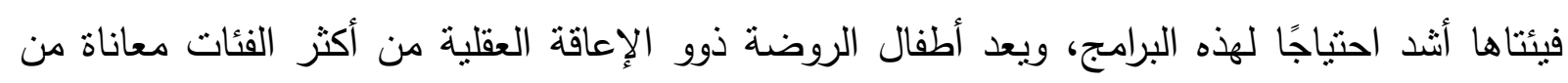

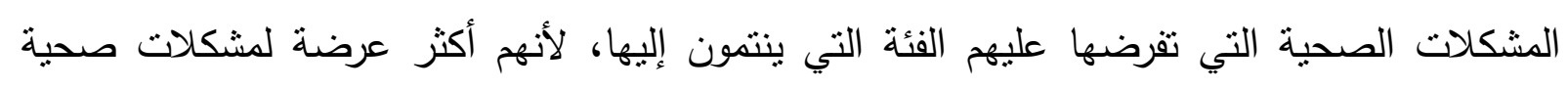

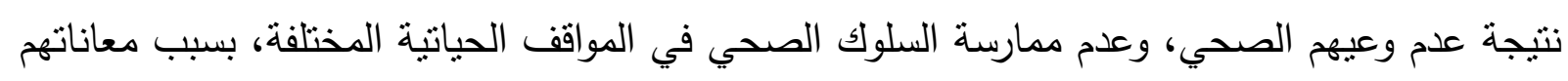

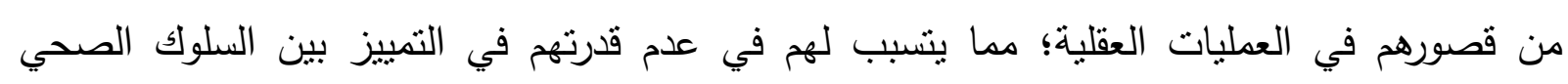

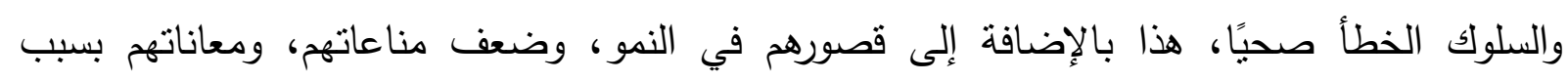

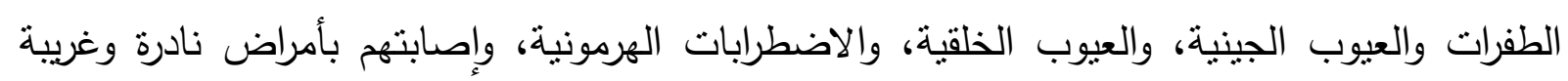


يصعب تشخيصها وعلاجها حتى الآن، وهم أكثر عرضة للحوادث والإصابة بالأمراض، لذلك فهم أكثر الفئات احتياجًا لتتمية الوعي الصحي لديهر.

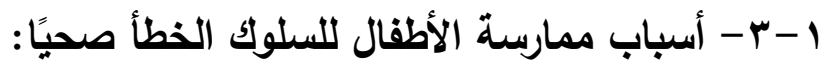

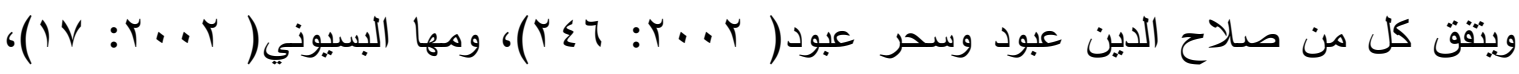

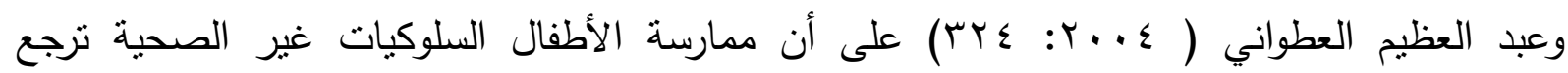

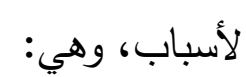

\section{ا . ضعف أداء السلوك الصحي لدى الأسرة، وقلة وعيها الصحي.}

r. التتاقض بين ما يكتسبه الطفل من سلوك خطأ صحيًا من الأسرة، وما يكتسبه الطفل من وعن الط

$$
\text { سلوك صحي صحيح بالروضة. }
$$

r. محاكاة الطفل لبعض سلوكيات الزملاء الخاطئة صحيًا في الروضة، كثراء أطعمة من بن

$$
\text { الباعة الجائلين. }
$$

ع. مواجهة الطفل المشكلات النفسية بشراهة في الأكل. 0. قصور سلوك الطفل في وقاية نفسه من الهخاطر الأمراض.

وفي ضوء ما سبق يمكن تقسيم أسباب ممارسة أطفال الروضة ذوي الإعاقة العقلية البسيطة للسلوك الخطأ صحيًا إلىى: وفي صنا

\section{1 أسباب بيولوجية، ومنها ما يأتي:}

- بسبب إعاقة الطفل نفسه مثل ميل الطفل المصاب بمتلازمة برادر - ويلي، والداون إلى الثراهة

$$
\text { في تتاول الأطعمة. }
$$

- معاناتهم من ضعف المناعة التي تؤدى إلى سهولة إصابتهم بالعديد من الأمراض.

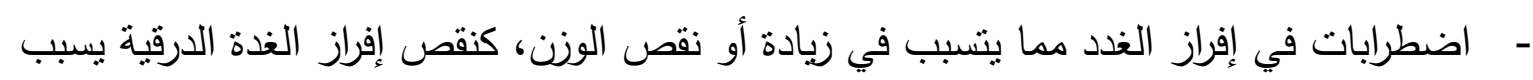

$$
\begin{aligned}
& \text { زيادة الوزن ، وزيادة إفرازها يسبب نقص في الوزن. } \\
& \text { r. أسباب عقلية، ومنها ما يأتي: }
\end{aligned}
$$

- أن قصور الطفل في العطليات العقلية كالانتباه، والإدراك، والتذكر، والتفكير يجعل من الصعب

$$
\text { عليه أن يمارس السلوك الصحي. }
$$

- أن لايه قصور في إدراك الخطر وتوقعه؛ مما يؤدي إلى كثرة تعرضه إلى المخاطر والحوادث

$$
\text { والأمراض من حوله. }
$$

- أن لديه قصور واضح في التمييز بين السلوك الصحي والسلوك الخطأ صحيًا. 


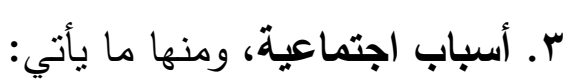

- قصور الوعي الصحي لدى أسرة الطفل، وعدم ممارستهم السلوك الصحي مع أنفسه، أو مع الطفل.

- - عدم الحرص من قبل الأسرة على إكساب الطفل السلوك الصحي. - قد يكون قصوره بسبب تدليل الطفل ذي الإعاقة العقلية الزائد من الوالدين، وعدم الحرص على على العلى توجيهه لأداء السلوكيات الصحية.

- - أن إهمال الطفل، ونبذه، ورفضه ممن حوله يؤدي إلى سلوكه عدة سلوكيات خطأ صحيًا، ومنها أن يعرض الطفل نفسه للخطر من خلال إيذاء نفسه صحيًا.

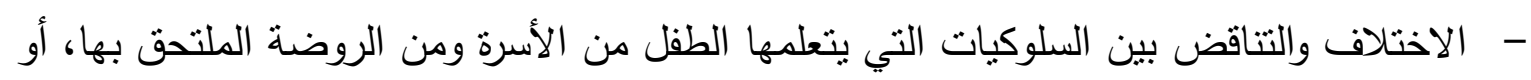

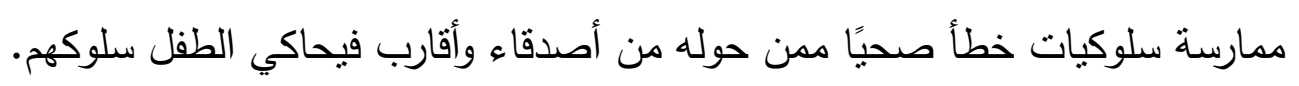
ع. أسباب نفسية، ومنها ما يأني: - - أن من شده الألم الذب يتعرض له بسبب كثرة الأمراض والمشكلات الصحية التي يتعرض لها، قد يؤدي به إلى سلوك سلوكيات غير صحية تؤذيه. هـ أسباب علاجية، ومنها ما يأتي: - - تناول الطفل لبعض الأدوية العلاجية الني قد تزيد من شهيته لتتاول الطعام. لللك يجب تتمية الوعي الصحي لأطفال الروضة ذوي الإعاقة العقلية البسيطة من خلال توفير برامج للتربية الخاصة تتلاءم معهم وتلبي احتياجاتهم. 1- - - مظاهر السلوك الخطأ صحيًا عند أطفال الروضة ذوي الإعاقة العقلية البسيطة: إن هناك العديد من المظاهر التي توضح تصاعدًا واضحًا في أداء السلوكيات الخاطئة المتعلقة

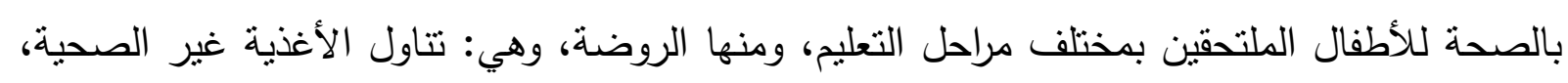

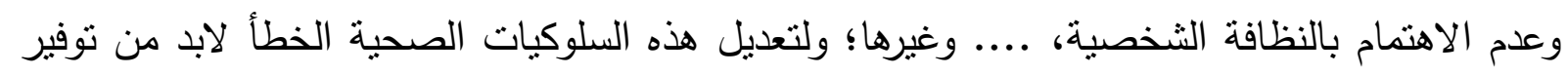

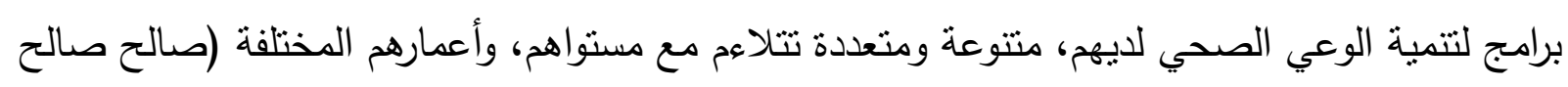

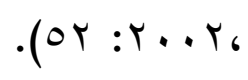

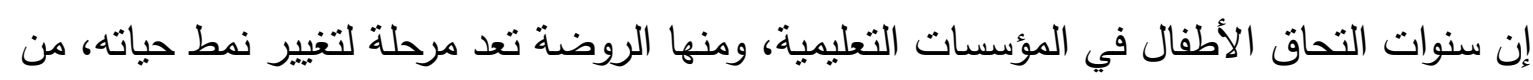
خلا إكسابه العادات الصحية السليمة منذ الصغر في الروضة؛ لتجنب عواقب عدم الالتزام الأطفال بالقواعد الصحية السليمة، وظهور العديد من السلوكيات الخطأ، ويعدد كل من محمود عشري (1999 ())،

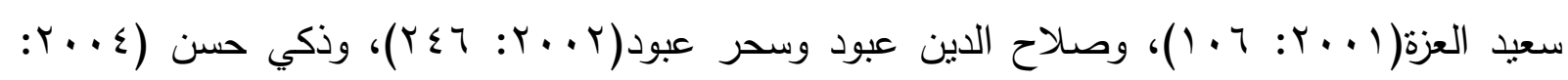




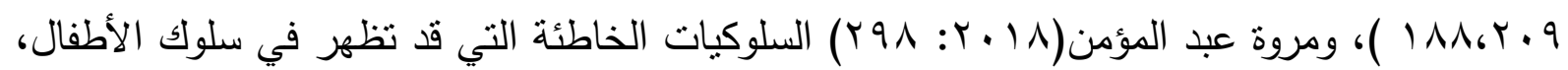
ومنها:

- شراهتهم في تتاول الطعام؛ ومما يؤدي إلى السمنة . - - - نتاول أطعمة غير صحية. - - استخدام الأطفال لأدوات بعضهم، ومنها :استخدام أدوات المائدة الخاصة بالآخرين. - - تناول الطعام من على الأرض. - - انحناء العمود الفقري. - وضع أجسام معدنية في مصادر التيار الكهربي. - - عدم تغطية الفم أثناء العطس. - البصق على الأرض، أو على الآخرين. - لبس ملابس لا تلاعم حالة الجو. - - التعامل مع الحيوانات، والقطط المشردة. - - عدم الاهتمام بنظافة المكان. - - إلقاء المخلفات في الطرق العامة. ومن خلا الاطلاع على الدراسات والبحوث السابقة وملاحظات الباحثة خلال عملها بروضات التربية الفكرية والزيارات الميدانية والمقابلات مع المعلمات وأولياء الأمور لهؤلاء الأطفال، يمكن تصنيف مظاهر السلوك الخطأ صحيًا لدى أطفال الروضة ذوبي الإعاقة العقلية البسيطة، إلى ما يأتي: ا ـ مظاهر السلوك الخطأ صحيًا الخاصة بعدم اهتمام بالنظافة الشخصية لدى أطفال الروضة ذوي الإعاقة العقلية البسيطة، ومنها ما يأني:

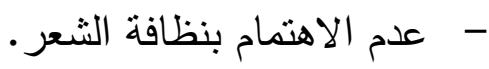
- - عدم غسل البد بعد استخدام دورات المياه. - لبس ملابس غير نظيفة، وعدم تغييرها. - - عدم العناية بالأسنان وتفريشها بالفرشاة الخاصة بها. - - عدم الاهتمام بنظافة الأظفار (الأظافر). 
r. مظاهر السلوك الخطأ صحيًا الخاصة بالتغذية لدى أطفال الروضة ذوي الإعاقة العقلية البسيطة، ومنها ما يأتي :

- - عدم تتاول الطعام الصحي المفيد، وانجذابهم للأطعمة الملونة الصناعية. - - عدم الحرص على تتاول الماء، وميلهم لثرب المياه الغازية أو العصائر الصناعية. - تناول كميات الأطعمة غير المناسبة لطول الجسم ووزنة؛ مما يؤدي إلى السمنة.

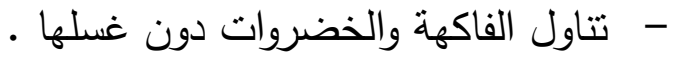
r. مظاهر السلوك الخطأ صحيًا التي تعرض أطفال الروضة ذوبي الإعاقة العقلية البسيطة للأمراض والمخاطر والحوادث، ومنها ما يأتي:

- - استخدام الأدوات الخاصة بالآخرين، متل ( الملابس، وأدوات الطعام، والمنشفة، والمشط، وفرشاة (الأسنان). - - عدم استعمال مناديل على الفم والأنف أثناء العطس والسعال. - - ت ت اول الطعام من الباعة الجائلين. - - - عدم التأكد من نظافة الماء قبل شربه. - - اللعب مع الحيوانات والطيور المشردة غير النظيفة.

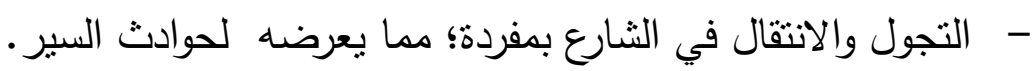

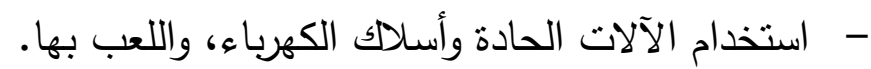
- - إلقاء القمامة في أي مكان في المنزل، والروضة، والثنارع دون الحرص على ألقائها في الأماكن الخاصة لها . الفاء

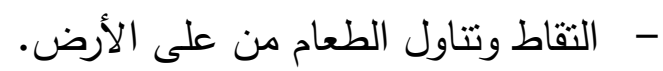
- تناول الأدوية بمفرده تقليدًا للكبار ، أو لأن الدواء محلي لـأل بالسكر فيحب الطفل طعمه. 1-ه - أهمية تنمية الوعي الصحي لاى أطفال الروضة ذوي الإعاقة العقلية البسيطة : إن الوعي الصحي لا يهتم بنشر معلومات نظرية فقط، وإن جميع الممارسات الصحية السليمة التي اعتاد الطفل ممارستها عمليًا، نسبق فهمه للمعلومات الصحية النظرية، لتصبح عادات صحية آلية دائمة له، يمارسها بدون شعور، وتمتعه بحياة صحية أفضل، وتساعد على وقايته من الأمراض بسبب كثرة

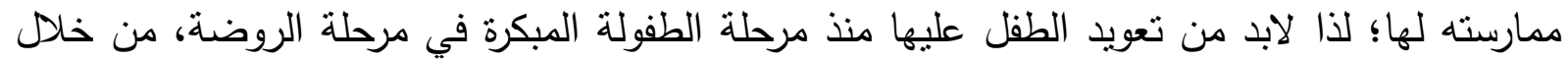

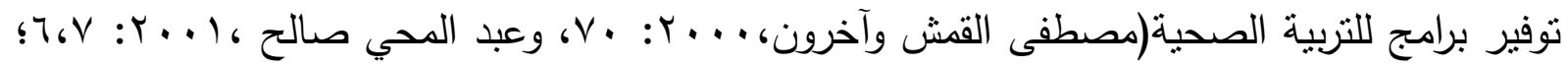

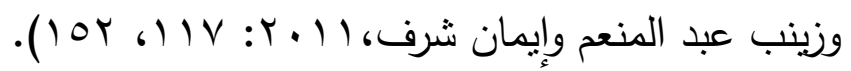




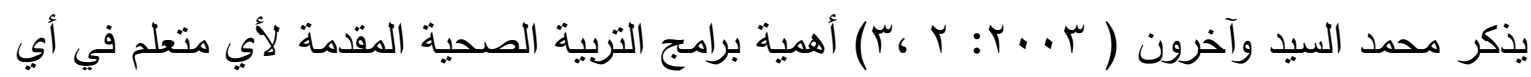
مرحلة دراسية ، ويتضح ذلك فيما يأني: ا. توفر جميع المعلومات الصحية، والخبرات التي يحتاجها المتعلم؛ ليستطيع المشاركة إيجابيًا في بئي حل مشكلاته الصحية التي تواجها، وقاية نفسه من الأمراض. r. تعدل الأفكار ، والسلوك، والاتجاهات بشكل إيجابي نحو ممارسة العادات الصحية. r. تساعد على انتثار المعلومات الصحية بين المتعلمين، وحثثه على تطبيقها، وممارستها. ع. تقديم كل ما يتم اكتثافه في مجال الصحة. ๑. تساعد المتعلم في الاستفادة من الخدمات الطبية الموجودة والمتوفرة بالمجتمع. ويشير كل من جيلبيرت وآخرون Gilbert, et al, (2000:84) إلى أنه يجب على جميع

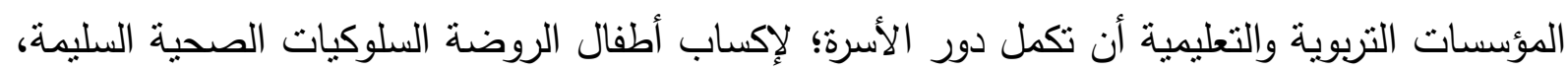

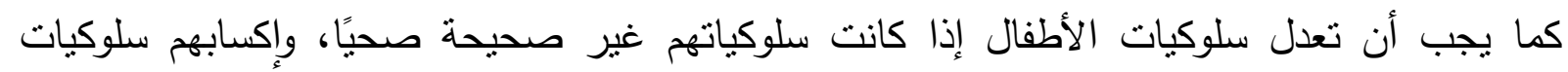
صحية جديدة صحيحة؛ لتتمية الوعي الصحي لديهم.

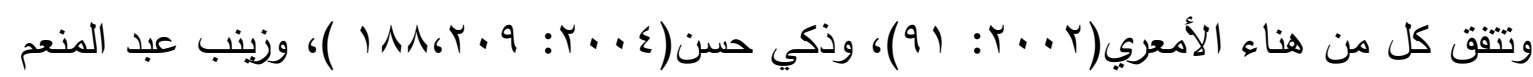

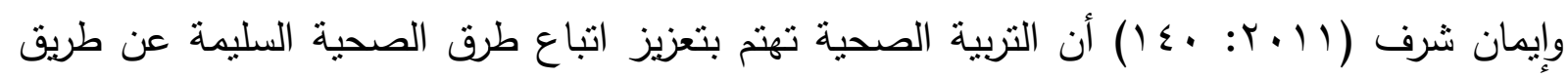

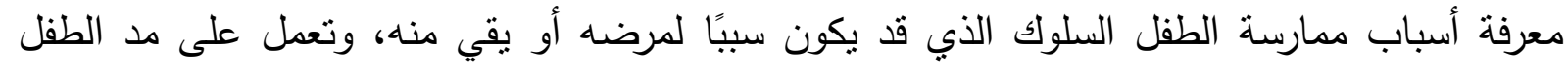
بالمعارف، والمهارات، والاتجاهات التي تجعله يمارس في حياته السلوك الصحي السليم؛ فلا يقتصر

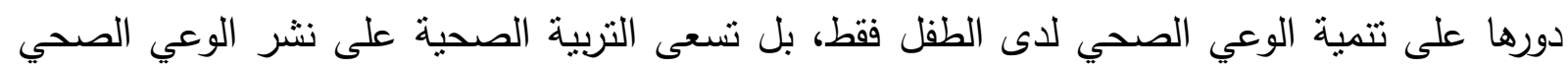
السليم بين أفراد أسرة الطفل أيضًا.

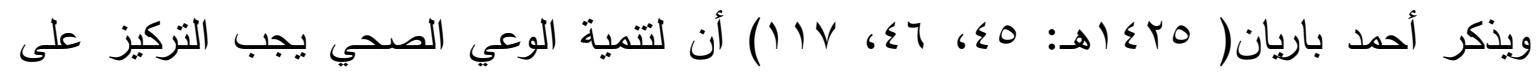
جوانب ممارسة السلوك الصحي الصحيح العملي التطبيقي، وعدم الاقتصار اكتساب المعارف والمعلومات فقط.

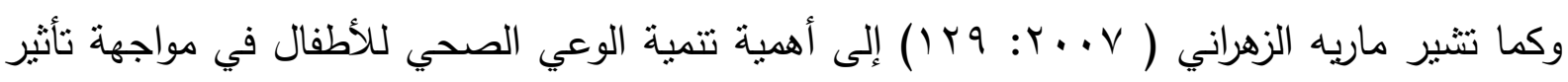

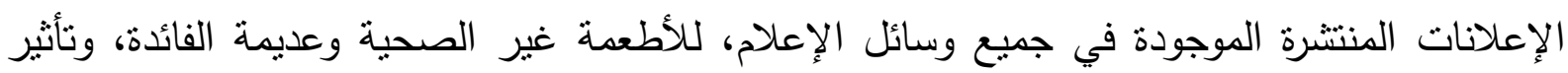
هذه الإعلانات على انتتار تتاولها بين فئة الأطفال .

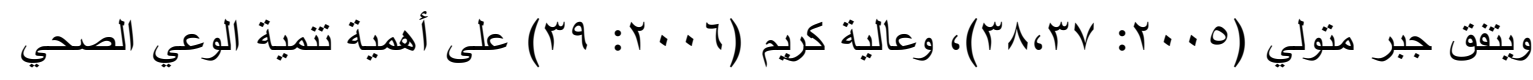
للأطفال وتعديل السلوكيات الخاطئة صحيًا لهم، للأسباب الآتية:

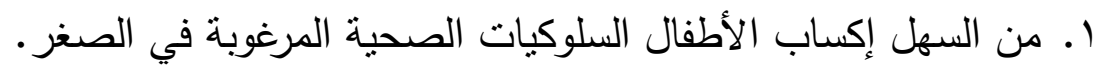


r. توعية الطفل بأن ممارسة السلوكيات الصحية السليمة يجعل حياته أفضل، كما أنها تحميه من الأمراض المختلفة.

r. يتعرض الأطفال داخل الروضة للعديد من المشكلات الصحية، كما يمكن أن يقلد الطفل

$$
\text { زملاءه في أداء السلوك الخطأ. }
$$

ء. أن السلوك الصحي يستمر ممارسته من الطفل طوال حياته؛ لذا يجب تعديل السلوكيات

الخاطئة صحيًا لديه.

ه. عدم إكساب الطفل للسلوكيات الصحية الصحيحة يجعله يواجه العديد من المشكلات

الصحية.

إن المشكلات الصحية التي يعاني منها الأطفال تتسبب في قصور في النمو الجسماني والعقلي، ولذلك مردود سلبي كبير على الإنتاج والدخل القومي؛ لزيادة تكاليف الرعاية الصحية المقدة لهم، ولتجنب تلك المشكلات يجب تقديم برامج تربية صحية منذ الصغر للأطفال، تساعد على تتمية الوعي لإي

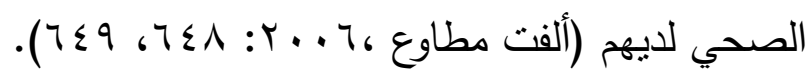

كما يؤكد فيهرمان (2006:149) عuhrman على أنه تظهر أهمية تتمية الوعي الصحي للأطفال من خلال وجوب توظيف الأحداث التي تحدث للأطفال، أو لمن حوله، وضرورة الاستفادة منها لتتمية الوعي الصحي لدى أطفال الروضة، مثل حدوث حادث طارئ، أو انتشار لمرض معين، واستغلال الموقف لإكساب الأطفال المعلومات اللازمة عن الحادث أو المرض من خلال عرضه على الأطفال بالإضافة إلى عرض طرق علاج الحادث أو المرض، بالإضافة إلى إتاحة الفرصة للأطفال لمعرفة طرق

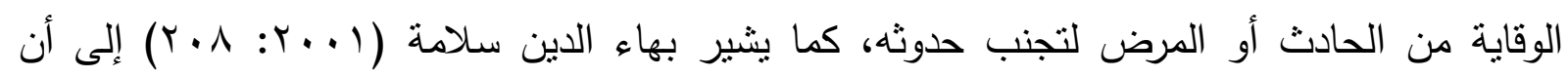
السلوك الصحي يعد مظهرًا من مظاهر الوعي الصحي؛ لأن امتلاك الفرد للوعي الصحي بحفزه على ممارسة السلوك الصحي.

نستخلص من العرض السابق أن أهمية تتمية الوعي الصحي لأطفال الروضة ذوي الإعاقة العقلية البسيطة ببرامج التربية الصحية، هي ما بأني:

- - تظهر أهمية الوعي الصحي باهتمامه بالممارسة العملية الآلية للسلوك الصحي الصادر من

الطفل بتلقائية، ولا تقف اهتمامه عند المعرفة النظرية فقط .

- تتمية الوعي الصحي يعدل اتجاهات الطفل ذي الإعاقة العقلية البسيطة نحو ممارسة السلوك

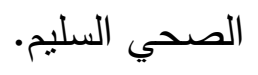

- - انتشار المعلومات الصحية بين الأطفال ذوي الإعاقة العقلية البسيطة، وبعضهم. 
- تقديم برامج التربية الصحية التي تسعى لتتمية الوعي الصحي يكمل دور الأسرة للطفل ذي الإعاقة العقلية البسيطة، كما بساعد في تقديم برامج للتربية الصحية لجميع أفراد أسرة الطفل إذا كان هناك احتياج لذلك. - يواجه تأثير الإعلانات الخاصة بالأطعمة غير الصحية المقدمة في وسائل الإعلام التي

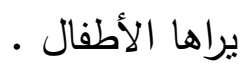
- تستغل فترة الروضة، والتي تتميز بسهولة تشكيل وإكساب السلوك الصحي الجديد، وتعديل السلوكيات الخطأ صحيًا بسلوكيات صحية صحيحة وسوية. - توظف الأحداث اليومية الطارئة في حياة الطفل والمنتشرة والتي دائمًا بمر بها الطفل،

$$
\text { وتستقيد منها في إكسابهم السلوك الصحي. }
$$

- - الحد من الكثير من المشكلات الصحية، والوقاية من الأمراض منذ مرحلة الروضة يساعد في توفير الدخل القوي الموجه للعلاج، ويتم الاستفادة من هذا الدخل في أغراض أخري يحتاجها أطفال هذه الفئة.

\section{1- - أبعاد برامج التربية الصحية لتنمية الوعي الصحي:}

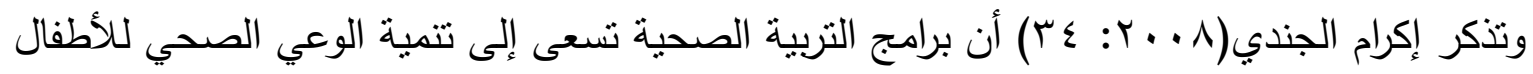
من خلال توافر أبعاد الآتية، وهي : ا. أبعاد معرفية : ويقصد بها إكساب الطفل المعلومات والمعارف الصحية الصحيحة. r. أبعاد وجدانية : ويقصد بها إكساب الطفل الاتجاهات والقيم الإيجابية للصحة. r. أبعاد مهارية : ويقصد بها ممارسة الطفل العملية للسلوكيات الصحية المتتوعة الصحيحة. 1 - أهداف تنمية الوعي الصحي لأطفال الروضة ذوي الإعاقة العقلية ببرامج التربية الصحية: يؤكد بينيت وآخرون (143 :Bennett, et al,2000) على ضرورة احتواء البرامج المقدمة للأطفال على برامج للتربية الصحية، والتي تهدف إلى تتمية وعيهم الصحي لإكساب الأطفال النظافة الثخصية، Harvey ) والاهتمام بالمظهر، ويجب أن تعلم وتكتسب مثل أي سلوك آخر، كما يؤكد هارفي 2004:61) على ضرورة توفير برامج تربية صحية، وأن يكون من أهدافها تعوبد الأطفال على النظافة باستمرار ، والعناية بنظافة اليدين قبل وبعد ثتاول الطعام.

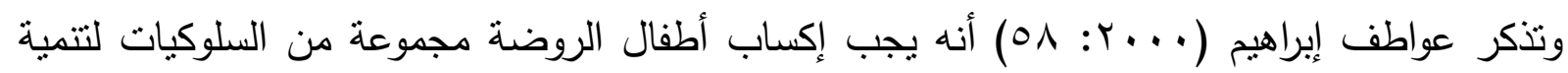
الوعي الصحي، وهي ما يأني: 
- تتاول الغذاء الصحي لجسم الإنسان، وطريقة تحضيره منل: العصائر، وسلطة الخضار، وسلطة الفواكه. - - نظافة اليدين بصفة دائمة قبل تتاول الطعام وبعده. - - - غسل اليد بعد استخدام دورات المياه.

- - إكساب الأطفال طرق الوقاية من العدوى (باستخدام المناديل، واستخدام الأدوات الثخصية). - تعويد الأطفال على الوقوف أمام المرآة لتسيق شعرهم، وملابسهم.

كما تذكر نايفة القطامي وعالية الرفاعي ( ( . . r: بـ () أن الهدف من تتمية الوعي الصحي للأطفال ببرامج التربية الصحية ، ويتم ذلك من خلال ما يأتي: - إكساب الطفل معلومات صحية مناسبة لعمره الزمني؛ لتساعده على أداء السلوك الصحي

$$
\text { الصحيح، ولمواجهه مشكلات الصحية، والجسمية. }
$$

- - تمكين الطفل من ضبط عضلات جسمه وتحكم بها؛ ليتمتع بحياة صحية سليمة. - تدريب الطفل على تجنب الأمراض المعدية، ووقايته من الحوادث المسببة للعاهات

$$
\text { الجسمية. }
$$

- - إتاحة الفرصة للطفل ليصبح شريكًا في برنامج التربية الصحية بعد ذلك. - - - تمتع الطفل بصحة ونشاط.

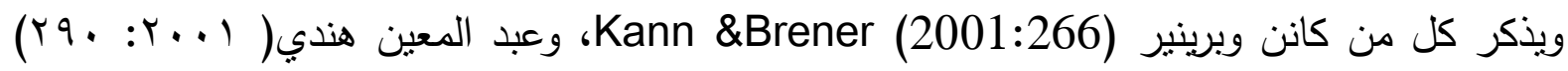
أنه يجب اشتمال البرامج المقدمة في المؤسسات التعليمية على برامج للتربية الصحية لتتمية الوعي الصحي؛ لأن المؤسسات التعليمية قادرة على تشكيل السلوكيات والعادات الصحية، والتي تهنم بالآتي: - - تشكيل السلوكيات الصحية السليمة، كالغذاء السليم. - تقديم الطرق الصحيحة الوقاية من المخاطر والحوادث التي قد يتعرض لها الطفل. - - مرق المحافظة على البيئة. - الاتجاهات الصحية الايجابية نحو السلوك الصحي ونحو المجتمع المحيط به.

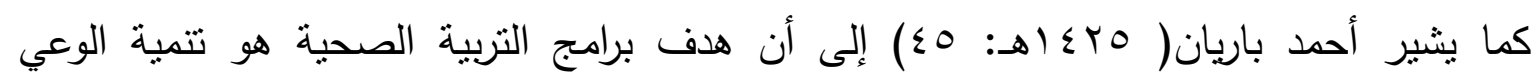
الصحي بالتزام الطفل بعادات صحية السليمة في حياته، كما تتيح الخدمات الصحية للأطفال، وتعلمهم كيفية الاستفادة منها، وتسهم في التذريب على طرق الحفاظ على الصحة، والحفاظ على البيئة، وزيادة تمتعهم بالصحة.

كما يشير محمد بسيوني (ع . . r: V-9) إلى أن تهدف برامج التربية الصحية إلى تتمية الوعي الصحي، من خلال ما بأني: 
ا ـ إكساب الأطفال المعارف والمعلومات الصحية الأساسية، وهي عن: جسم الإنسان، ووظائف أعضائه

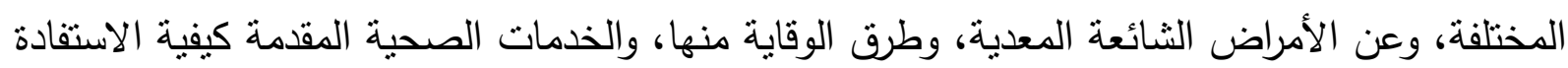

r. إكساب الاتجاهات الصحية الصحيحة، ويتم ذلك من خلال: الحفاظ على البيئة من التلوث، تكوين اتجاهات إيجابية للنظافة، مقاومة الخرافات في حل المشكلات الصحية ، الرجوع إلى المتخصصين في

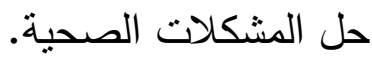

r. إكساب مهارات ممارسة السلوك الصحي السليم، ويتم ذلك من خلال: تتاول الغذاء السليم، الححافظة

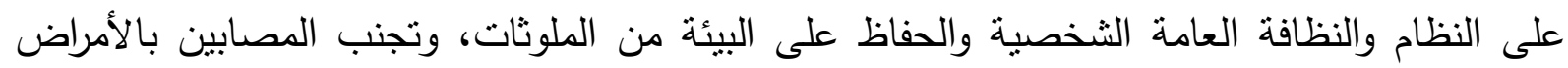
الوبائية المعدية، والتطعيمات، وطرق الإسعافات الضرورية البسيطة الأولية عند الحاجة.

تهدف تتمية الوعي الصحي للأطفال في مرحلة الطفولة المبكرة إلى إكساب السلوكيات الصحية

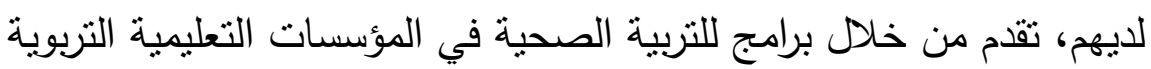
2005:103) السلوكيات تتلخص فيما يأتي: - - ضرورة غسل اليدين بالماء والصابون قبل الأكل وبعده، وكذلك بعد اللعب بالألعاب، وضرورة غسل اليدين بعد استخدام دورة المياه. - الاستحمام المستمر يومياً بفصل الصيف، ومرتين بالأسبوع بفصل الثنتاء. - - إكساب الأطفال طرق استخدام دورات المياه، بطريقة صحية صحيحة. - - إكساب الأطفال طريقة تفريش الأسنان يوميًا مرثين، بطريقة صحيحة. - - الاهتمام بتمشيط شعر الرأس يوميًا.

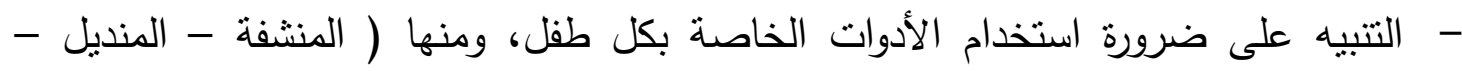

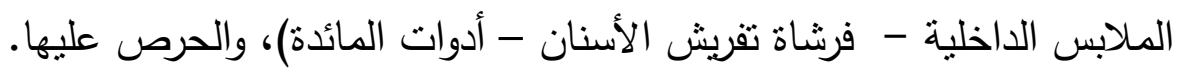
- الاهتمام بنظافة القدمين، وغسلها يوميًا، والحرص على لبس الأحذية. - تغيير الجوارب يوميًا. - - الحرص على تغير الملابس الداخلية والخارجية، ولبس ملابس نظيفة. - - التدريب على تقليم الأظفار (الأظافر). - إكساب الأطفال طرق تتظيف الأنف بالمناديل باستمرار . - - إكساب الطفل مهارة تغطية الفم والأنف أثناء العطس والسعال. 


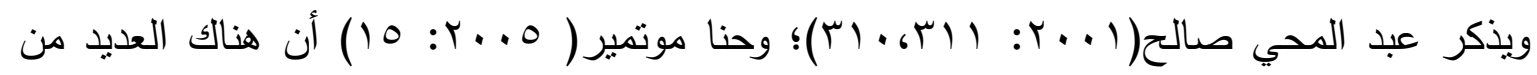
المظاهر والأنماط للسلوك الصحي التي يجب إكسابها للأطفال، ومنها: - - غسل اليدين قبل وبعد تتاول الطعام، وبعد قضاء الحاجة في دورات المياه. - - - غسل الخضروات والفاكهة قبل تتاولها.

$$
\text { - قص الأظفار (الأظافر). }
$$

- - عدم استخدام أدوات الآخرين مثل أدوات المائدة والمنشفة. - تقريش الأسنان بالفرشاة والمعجون. - - تغطية الأطعمة لحمايتها من التلوث.

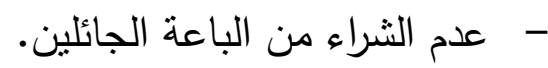
- - إبعاد الذباب عن الطعام ومكافحته.

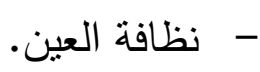
- عدم زيارة المرضى المصابين بأمراض معدية، والاقتراب منهم •

كما أكدت نتائج دراسة ألفت مطاوع (T . . Y) من خلال إعداد وحدة دراسية في المرحلة الابتدائية

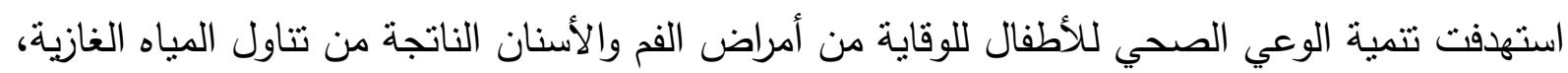

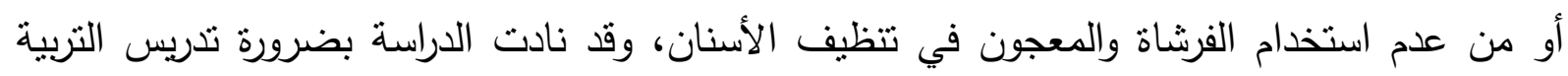

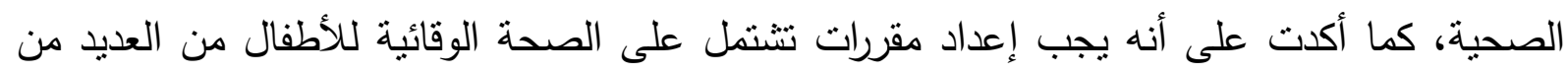
المشكلات الصحية في المراحل التعليمية المختلفة، وتقدم بطرق تتلاءم مع المرحلة العمرية المقدمة لها. وتضيف ناهد شعبان ( ^ ...r: 19 1) أن السلوكيات الصحية التي يجب تدريب الأطفال عليها

ا ـ سلوكيات النظافة والعناية الثخصية. r. الالتزام بتعليمات السلامة والأمان في ما يأني : (تناول الأطعمة من الباعة الجائلين، والسير في

$$
\text { r. الالتزام باستعمال الأدوات الثخصية. تعليمات المرور ...إخخ). }
$$

كما وضع مجلس ولاية كاليفورنيا للنعليم (2008) California State Board of Education) مجموعة من المعايير تهذف لتتمية الوعي الصحي لأطفال مرحلة الروضة من خلال برامج التربية

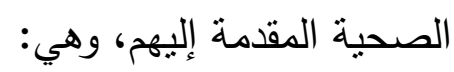
المعيار الأول: الوعي الغذائي وممارسة النشاط البدني : 
- تعريف الطفل على الأطعمة الصحية.

- - أهمية تنتاول الوجبات المختلفة، وعلى الأخص وجبة الفعلة الفطار . - حث الطفل على ممارسة الأنشطة البدنبة بصورة مستمرة. المعيار الثاني: متابعة النمو: - تعريف الطفل على أجزاء جسمه المختلفة وحواس، ووظيفة كل جزء.

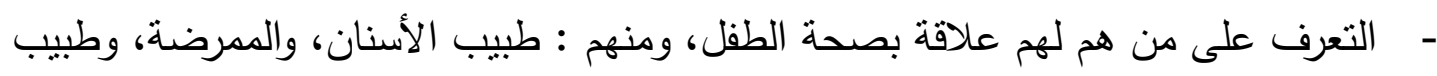

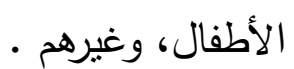

المعيار الثالث: تحقيق السلامة والوقاية والحماية : - التدريب على الأمن والسلامة في المنزل، والروضة، والبيئة. - - - التدريب على أمن والسلامة في الثنارع.

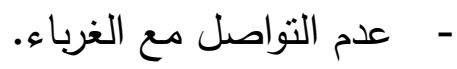
- - مدم استخدام الآلات الحادة والخطرة.

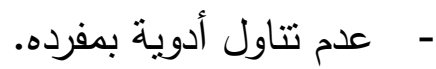

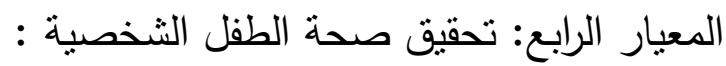
- - التدريب على كيفية الحفاظ على الصحة الأسنان. - عدم التعرض لأشعة الثمس الضارة. - - الحث على إعطاء الجسم وقت الراحة من خلال النوم.

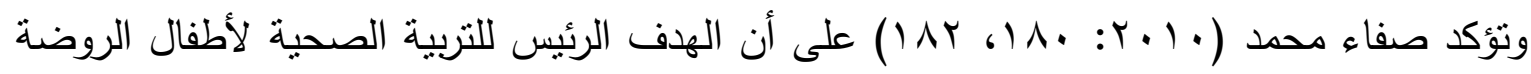

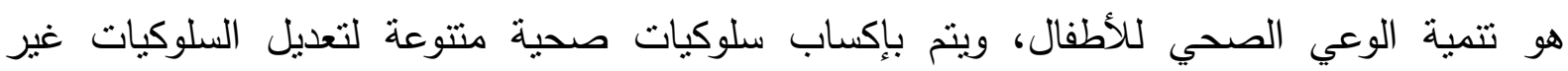

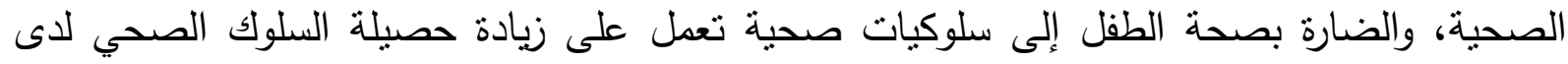

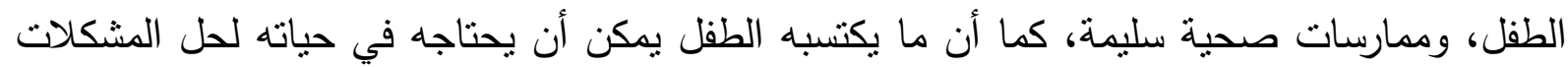
الصحية التي قد يتعرض لها فيما بعد، ويتضح ذلكاته فيما يأني : ا. إكساب الأطفال السلوك الصحي المرتبط بما يأتي : نظافة أعضاء الجسم المختلفة،

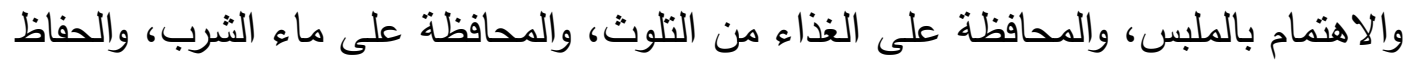

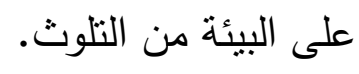

r. إكساب الأطفال العادات الغذائية الصحيحة، ومنها ما يأتي: تتاول الطعام الصحي، لتحقيق النوازن بين وزن الطفل، وطوله. 
r. إكساب الأطفال مهارات السلامة، والأمان، والحماية من الأخطار، منل : عدم الاختلاط

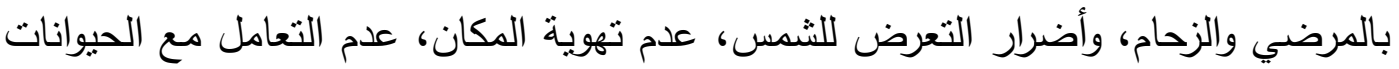

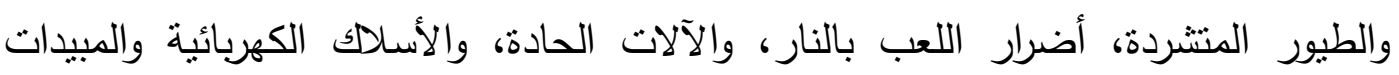

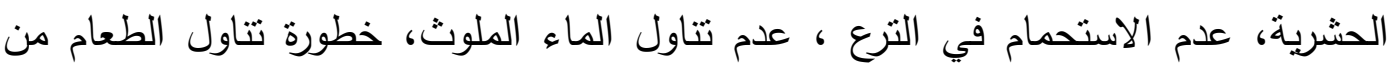

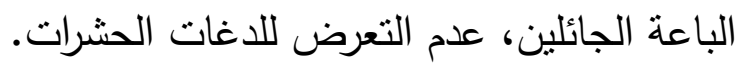

ع. توعية الأطفال بالخدمات الطبية المتاحة لهم، ومنها: الوحدات الصحية، وأعضاء الفريق

$$
\text { الصحي والإسعاف، والمطافئ، والتطعيمات. }
$$

0. اكتساب الأطفال الوعي بالرياضة، وأهميتها لسلامة اجسامهر.

تضيف زينب عبد المنعم وإيمان شرف (11 ـr: •ـ () أن من أهم الأهداف الرئيسة في مرحلة

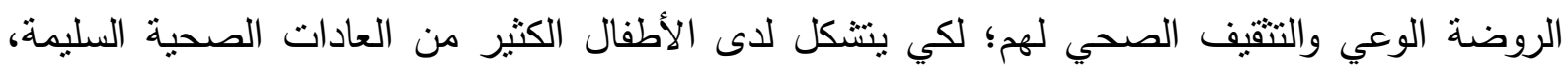

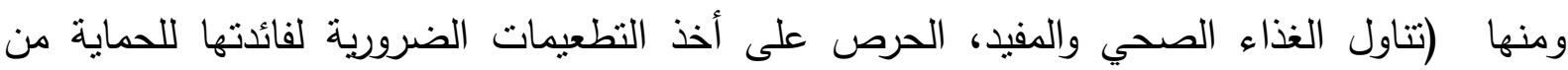
المرض، وممارسة المهارات الرياضية للحصول على اللياقة والصحة البدنية، واتباع التعليمات البيئية

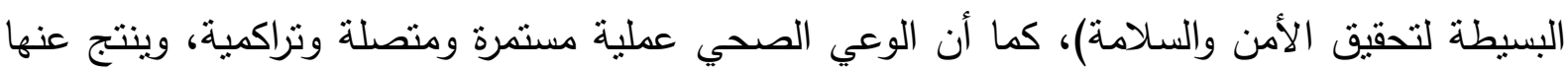

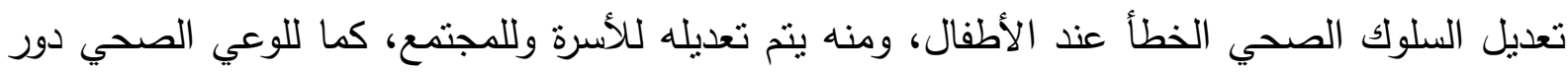
كبير في الوقاية من الأمراض.

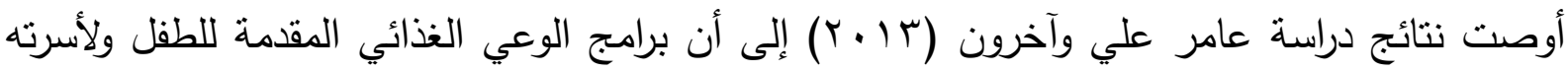

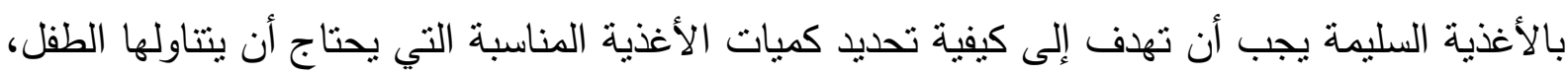

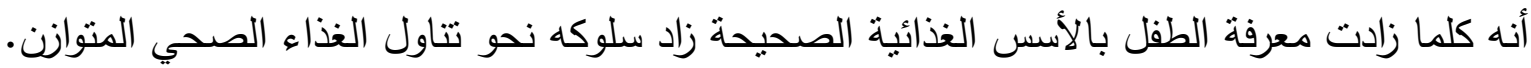
وتهدف التربية الصحية في مرحلة الروضة( مؤسسة برامج الطفولة بوزارة الصحة الفلسطينية، 1 ــ؟:

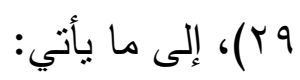
1 إكساب السلوكيات الصحية السليمة. r. ت. توضيح للأطفال منطلباتهم للنمو الجسمي السليم، وطرق المحافظة على أجسادهم.

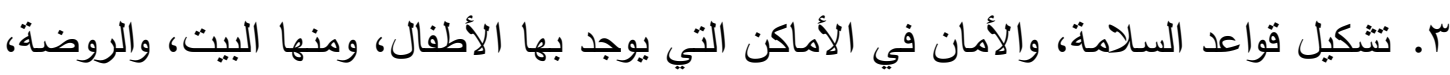

$$
\text { والثارع. }
$$
ع. إكساب الأطفال اتجاهات إيجابية نحو المحافظة على البيئة من حوله.

وقد قدمت المنظمة العالمية لتعليم الأطفال الصغار National Association for The Education) of Young Children,2017)

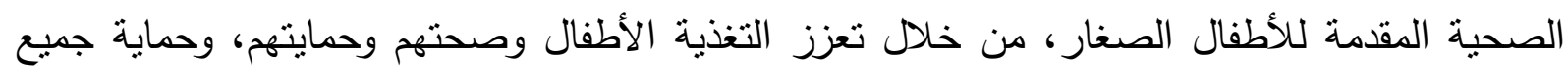


أعضاء هيئة التدريس والموظفين والعاملين من الأمراض والإصابات، كما يجب أن يتمتع جميع الأطفال بالصحة والأمن للحصول على تعلم أفضل من خلال توفير ما يأني : - - الوعي الصحي الغذائي، وتوفير وجبات غذائية أمنة للأطفال .

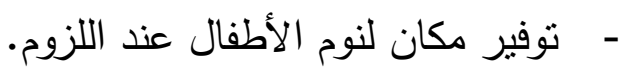
- - تدريب أعضاء هيئة التدريس على الإسعافات الأولية التي يحتاجها الأطفال.

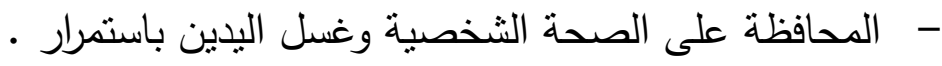
- تنظيف وتعقيم جميع الأسطح والمرفق بشكل دوري روتيني.

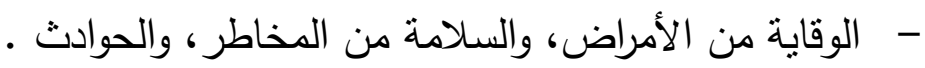
- وجود خطة للأطفال المرضى، وطرق تحديد حاجة الطفل إلى العودة للمنزل، وطرق إخطار

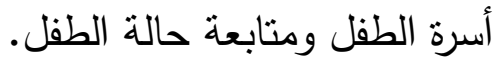

من خلال العرض السابق يتضح أن تتمية الوعي الصحي لأطفال الروضة ذوبي الإعاقة العقلية

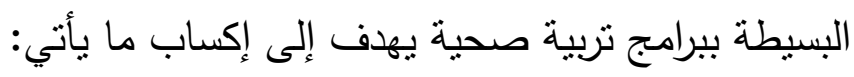

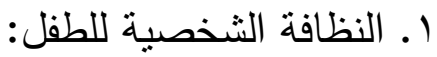

- - يميز أدوات النظافة الثخصية المختلفة، ويحدد وظيفة كل منها. - نظافة الثعر من خلال غسلة، وتمشيطه باستمرار .

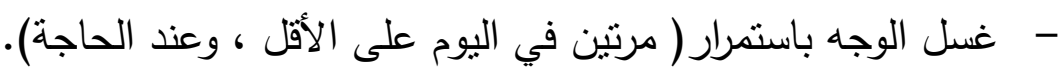
- - - غسل اليد بعد استخدام دورات المياه.

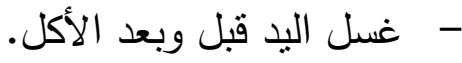
- تغير الملابس باستمرار ( الاخلية، والخارجية، والجوارب). - تفريش الأسنان يوميًا ( مرتين في اليوم قبل النوم، وبعده).

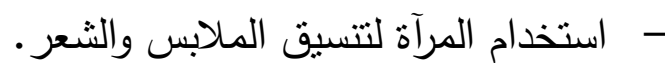
- - تقليم الأظفار (الأظافر باستخدام مبرد خشب). - - تكوين اتجاهات ايجابية نحو ممارسة سلوكيات النظافة الثخصية.

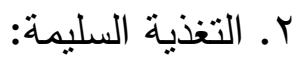

- - يميز أدوات المائدة المختلفة، ويحدد وظيفة كل منها. - - تتاول الطعام الصحي المتوازن لجسم الطفل وطوله، بالكمية المسموح له بهاء ولها.

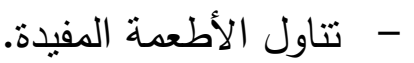
- التأكد من نظافة الطعام غسل الخضروات والفاكهة قبل الأكل. 
- - شرب ماء نظيف.

- تكوين اتجاهات إيجابية نحو تتاول الطعام الصحي.

r. تجنب الأمراض والمخاطر وتتمية مهارات السلامة والأمان:

- - عدم استخدام أدوات الخاصة الآخرين، مثل: الملابس، والأدوات الطعام، والمنشفة، المشط، وفرشاة الأسنان.

- - استخدام مناديل على الفم والأنف أثثاء العطس والسعال.

- - - يقف ويمشي ويجري بشكل صحيح. - - - عدم تتاول الطعام من الباعة الجائلين.

- - تجنب شرب المياه الغازية والعصائر الصناعية الملونة. - - تجنب اللعب مع الحيوانات والطيور المشردة.

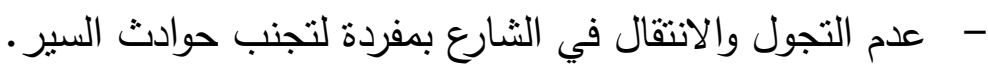

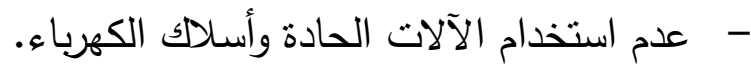

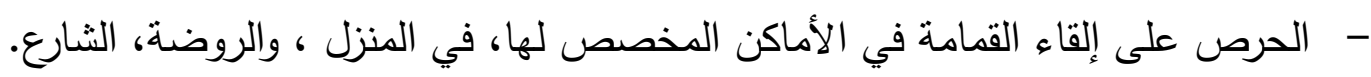

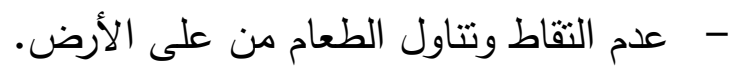
- - عدم تتاول الأدوية بمفرده، ودون استثارة من الطبيب.

1-1-1الأسس السيكولوجية لبرامج التربية الصحية لتنمية الوعي الصحي لأطفال الروضة: إن برامج التربية الصحية المقدمة لتتمية الوعي الصحي لطفل الروضة لها أسس سيكولوجية تبنى

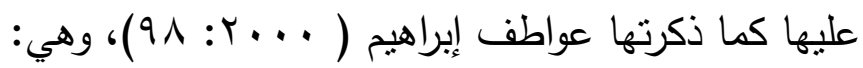

- أن المستوى الاجتماعي، والاقتصادي، والثقافي، والبيئي لأسرة الطفل له نأثير كبير على

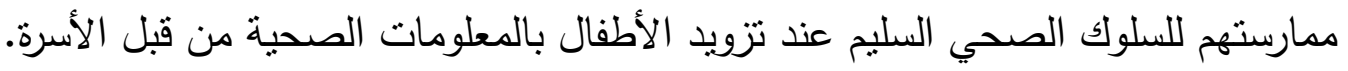
- - كل طفل يولد ولديه قدرة على التعلم والتعليم. - أن أي سلوك صحي كالنظافة مثلًا يتعلمه الطفل من خلاد الأنشطة، وممارستها. - أن محاكاة الطفل لمن حوله من الكبار لها دور كبير في أداء الطفل السلوكيات الصحية

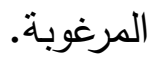
- - يجب نوفير تعلم وتعليم الأطفال المهارات والقواعد التي لها علاقة بالسلوك الصحي السليم من خلال الحواس. 


\section{1-9 - مراحل تنمية الوعي الصحي للأطفال:}

يشير كل من زيجلير وآخرون(Zigler ,et al, إلى أن تتمية الوعي الصحي للأطفال

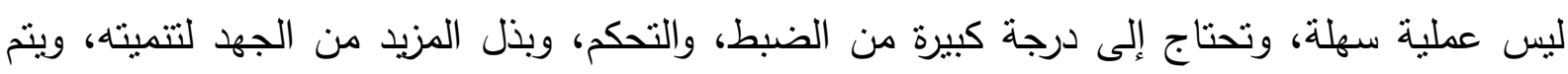
تتمية الوعي الصحي للأطفال من خلال المراحل الخمسة الآتية: ا. مرحلة التهيئة: تتم من خلال ملاحظة الأطفال، والمناقثات، والزيارات الميدانية، واللقاءات،

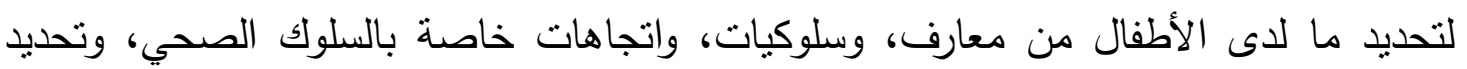
السلوكيات الصحية التي يحتاج الأطفال لاكتسابها.

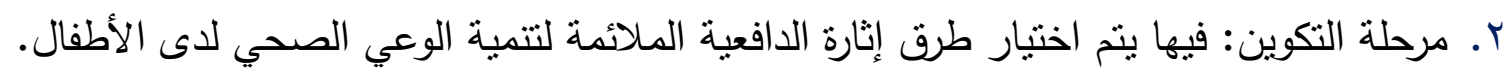

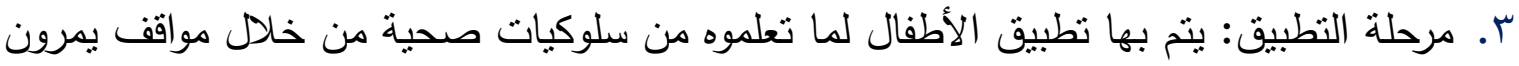

بها. ع. مرحلة التثبيث: يتم فيها توفير مواقف إثرائية منتوعة، وأنشطة مختلفة بتعميق ما تم إكسابه لكأطفال. 0. مرحلة المتابعة: من خلال متابعة ملاحظة أداء الأطفال للسلوك الصحي، وتطبيقها في حياتهر

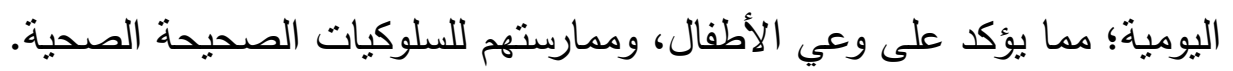
1- ـ 1- دور المعلمة في تنمية الوعي الصحي لاى أطفال الروضة ذوي الإعاقة العقلية البسيطة: أعضاء فريق عمل برامج التزبية الصحية داخل المؤسسات التعليمية، ومنها الروضة يتكون مما يأني

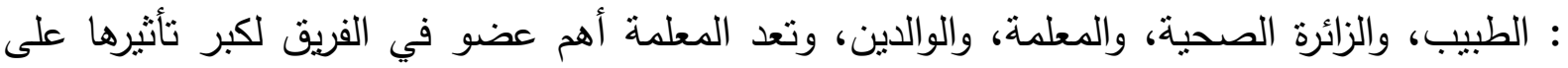

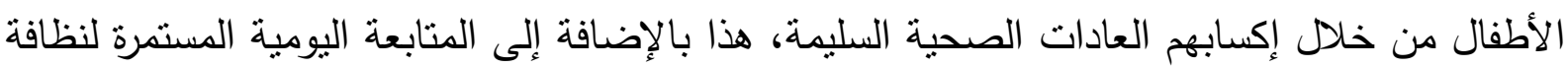

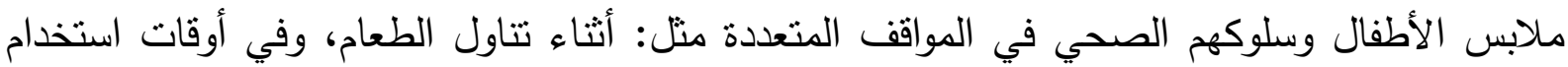
دورات المياه، كما تعمل المعلمة على توعية الوالدين إذا كانوا بحاجة لذلك. ويؤكد وكانن وبرينير (266 : Kann \& Brener أنه يجب أن تكون المعلمة قدوة في أي سلوك يصدر منها أمام أطفالها، كما يجب أن تكون ملتزمة بأداء السلوكيات الصحية السليمة في كل سلوكيتها، ولابد من الحظر في أداء أي سلوك مخالف للسلوكيات الصحية أمام الأطفال، ومنها إلقاء

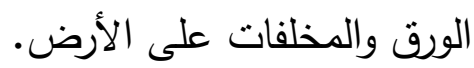
وللمعلمة دور إيجابي في التربية الصحية المقدمة في المؤسسات التعليمية، ويعددها محمد السيد

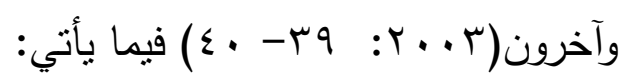


ا. تلاحظ في بداية العام الدراسي البيئة الصحية بالمؤسسة التعليمية التي تتنمي إليها، ومنها (ملاحظة دورات المياه، وطرق التخلص من الفضلات، وسلامة مياه الثرب، ومراقبة الأغذية (المقدمة).

r. تساعد الطبيب في ملء الاستمارة الصحية الخاصة بكل طفل. r. متابعة حجرات الدراسة، والتأكد من التهوية الجيدة، وتوفير الإضاءة، والأساءة الأساس المناسب للأطفال. ع. تعمل على غرس السلوك الصحي للأطفال، والعادات الغذائية المفيدة. 0. متابعة الأطفال الغائين، وسبب غيابهم، ومتابعتهم بعد حضورهم، والتأكد من شفائهم من خلال شهادات طبية رسمية.

7. الإثراف الصحي اليومي، والإلمام بالأمراض المنتشرة بالبيئة المدرسية، وطرق مقاومتها. V. في حالة توفر وجبة التغذية في المؤسسة التعليمية تعمل بالإثراف عليها مراقبتها.

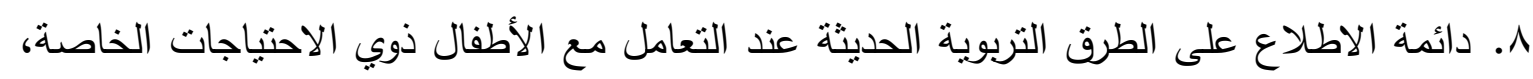

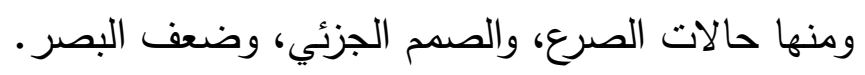

إن من أهم أدوار المعلمة هو تتمية الوعي الصحي لأطفال الروضة، فيجب أن تكون مثلًا بحتذى به

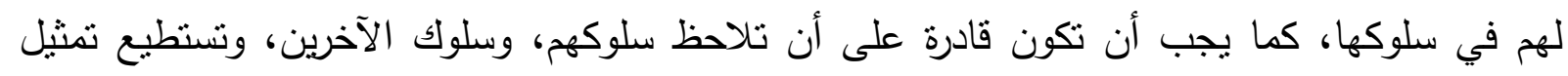

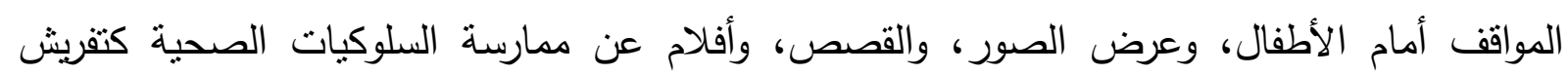

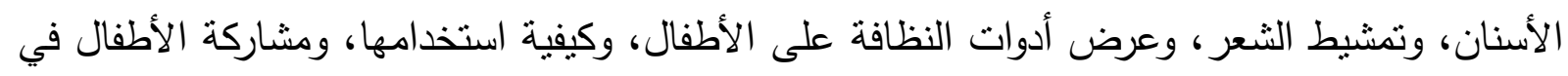

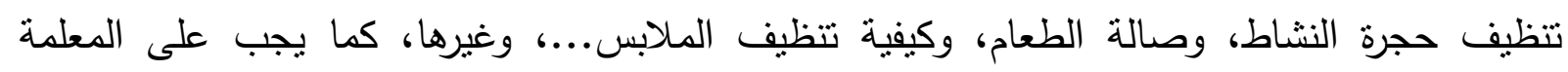

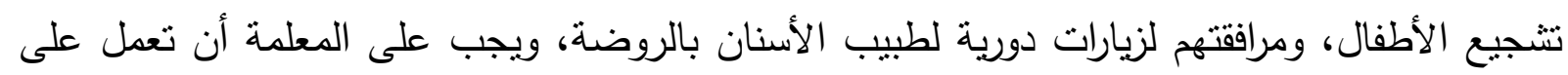

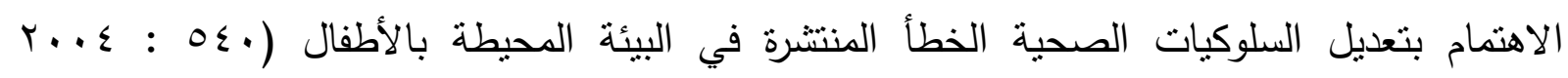

.( Johnathan,

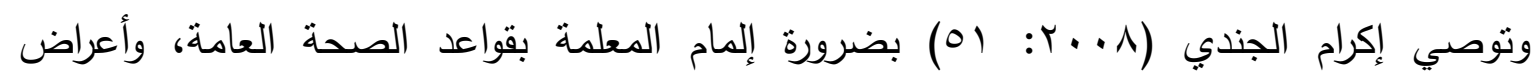
الأمراض المعدية المنتشرة بين الأطفال، وكيفية الوقاية منها، وملاحظة سلوك الأطفال أثناء أداء

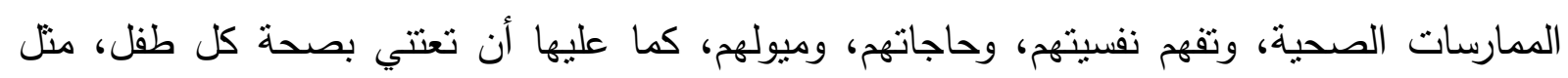

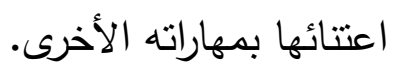

إن لمعلمة الروضة الدور الأكبر في تشكيل شخصية الأطفال، وإكسابهم الاتجاهات الإيجابية تجاه

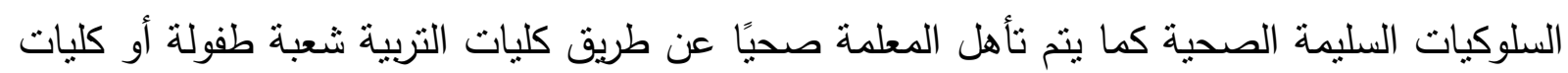

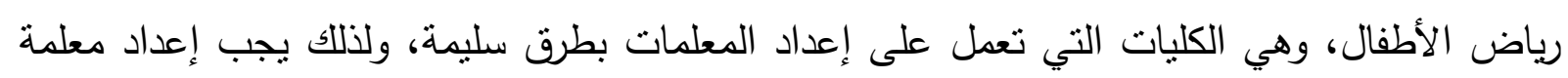
رياض الأطفال المؤهلة للرعاية الصحية للأطفال، وعلى تقديم برامج التربية الصحية للأطفال لتنمية

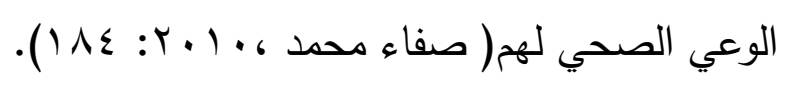


تعد الروضة من البيئات المناسبة لتقديم التربية الصحية للأطفال، ففيها يقضى الأطفال أغلب أوقاتهم

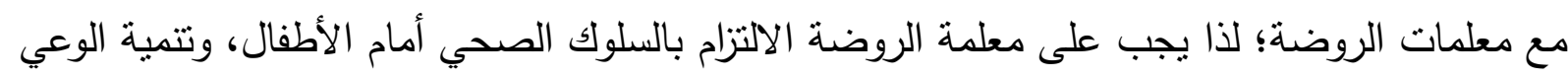

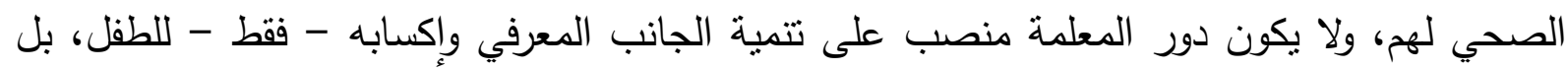

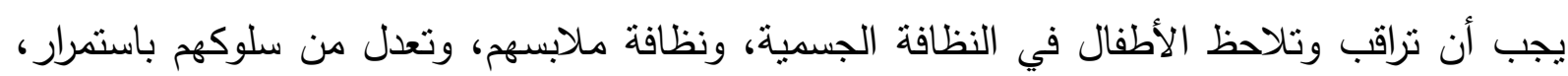

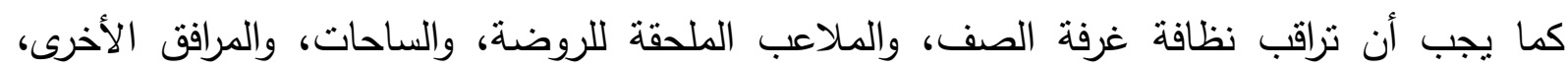
ومنها(الحمامات، والمقاصف)، ومن أهم أهداف التربية الصحية في مرحلة الروضة لتنمية الوعي الصحي، وهي : نظافة الجسم، والملابس، ونظافة الفم والأسنان، والوقاية من الحوادث المنزلية، وتنتاول

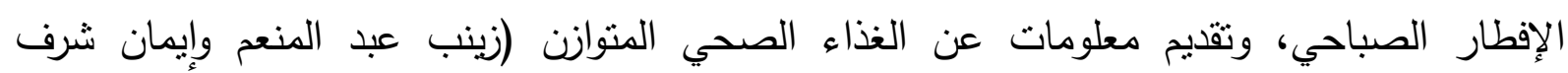
$\cdot(10 \cdot: 4 \cdot 1)$ ،

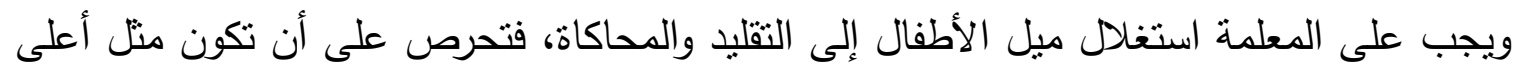
للأطفال في ممارسة السلوكيات الصحية السليمة أثناء الجلوس، والمشي، و و...غيرها من السلوكيات الصحية (Walker,2005:69 ).

ومن خلال العرض السابق، ومن خلال عمل الباحثة كمعلمة روضة لأطفال ذوي الإعاقة العقلية

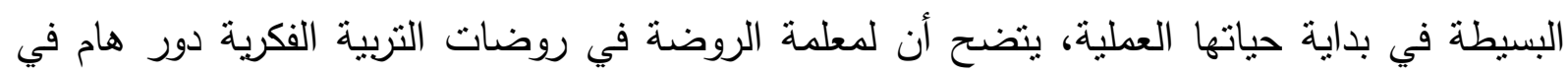
حياتهم وينلخص ذللك، فيما يأتي: - - عليها أن ثراقب وتلاحظ نفسها أولاًا في أداء السلوكيات الصحية، وأن تتقنها على الوجه الأكمل، لأن الأطفال ذوي الإعاقة العقلية يعتبرونها قدوة لهم ويقلدونها دائمًا. - على معلمة الروضة للأطفال ذوي الإعاقة العقلية أن تطور نفسها في مجال التربية الصحة. لإنها.

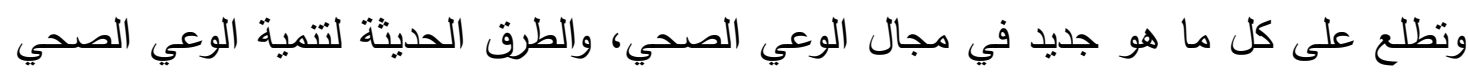

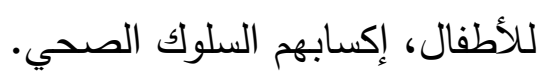

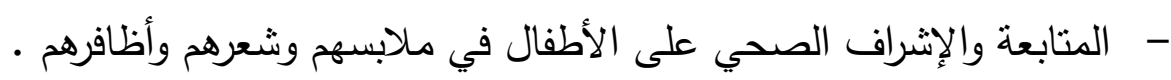
- - متابعة حالة الطفل الصحية، ومتابعة أيام غيابه. - المشاركة في الإثراف على الروضة من خلال متابعة البيئة الصحية للفصل( كالتهوية،

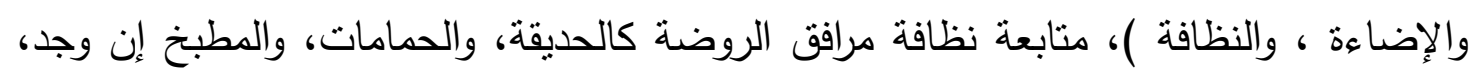
ومتابعة صلاحية الوجبات الجافة المقدمة للأطفال أو الوجبات المطهية.

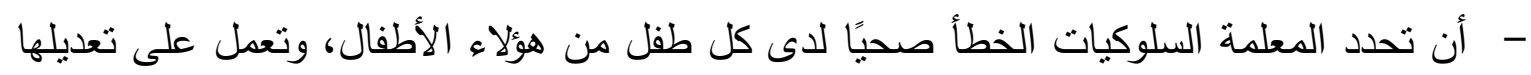
له. - أن تكسب هؤلاء الأطفال السلوكيات الصحية التي يحتاجونها. 
- أن تتعاون مع أسرة الطفل، وأن تقدم النصح والإرشاد لجميع أفراد الأسرة عن أهمية الوعي

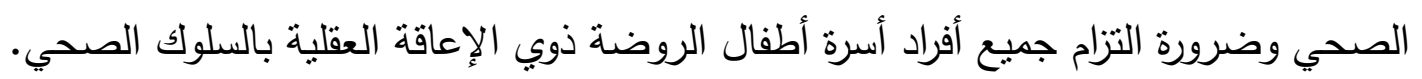

\section{1-11 - طرق تنمية الوعي الصحي ببرامج التربية الصحية}

أن تتمية الوعي الصحي ببرامج التربية الصحية يمارس عبر العصور باستراتيجيات وطرق متعددة،

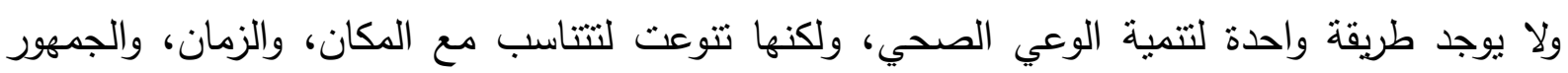

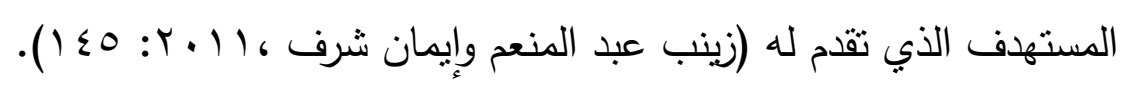

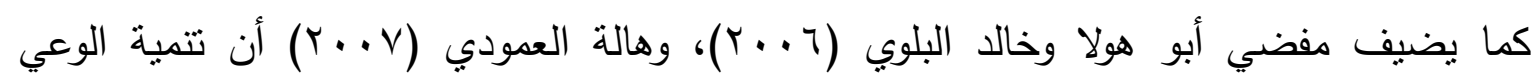
الصحي ببرامج التربية الصحية لأفراد المجتمع يجب أن تقدم باستمرار، وفي أب عمر، ولكنها تصبح

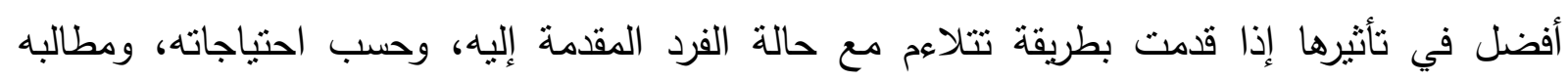

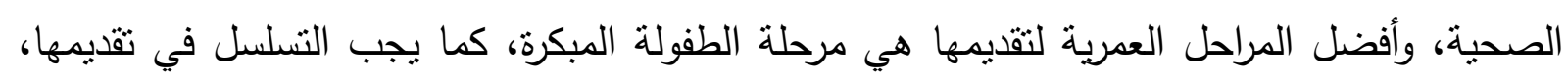
وتدريجها بما يتتاسب مع عمر الطفل الذي تقدم إليه. وتوصي كل من نايفة القطامي وعالية الرفاعي(1 +..؟: 90 (1) أنه يجب عند تقديم برامج التربية

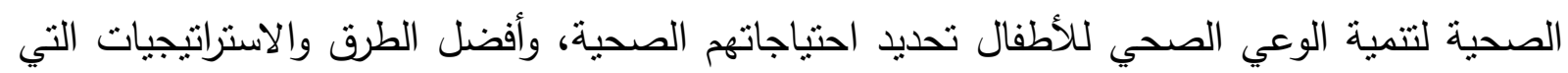

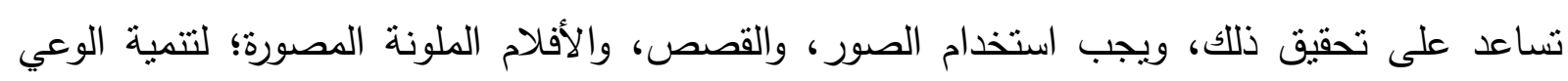

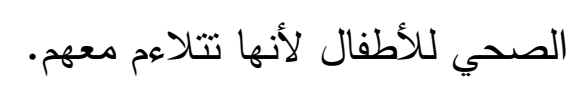

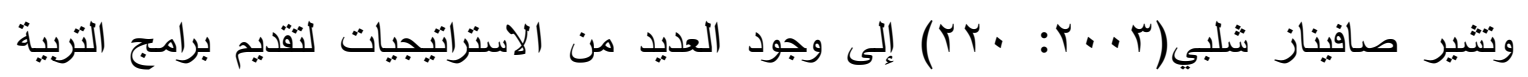
الصحية للأطفال ذوي الاحتياجات الخاصة لتتمية الوعي الصحي لديهم، وكل منها لها لهئ مديزاتها والفئة

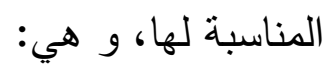

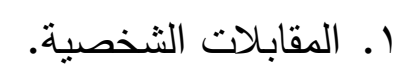

r. أفلام الفيديو وأفلام الكارتون والرسوم المتحركة.

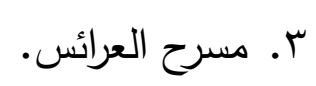$$
\text { ـ. القصص. }
$$

0. - الموسيقى والأناشيد.

$$
\text { T. الألعاب التمثلية ولعب الأدوار. }
$$

v. الألعاب الورقية، ومنها القص واللصق وألعاب البازل.

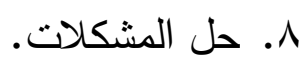

9. الصحف والمجلات الدورية العامة والمتخصصة. 
• ا ـوسائل الإعلام: دور السينما والراديو والتلفزيون.

11 ـ المحاضرات والمناقثات والندوات والمناظرات.

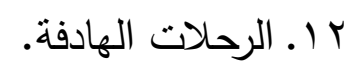

وتذكر ناهد شعبان ( 1 ... ז: 91 (1)) أن هناك بعض الطرق التي تعمل على تتمية الوعي الصحي للأطفال من خلال برامج التربية الصحية، وهي كالآتي: - - مؤسسات التربية والتعليم: بجميع مراحلها ومستوياتها التعليمية بداية من مرحلة الروضة، ويتم

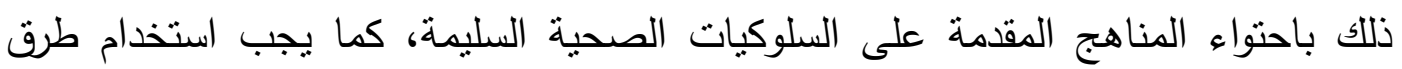
وأساليب التدريس التي تربط بين حياة الأطفال، والحقائق والمبادئ العلمية المرتبطة بالصحة. - - وسائل الإعلام، ومنها: المجلات، والإذاعة، والتلفزيون، والسينما، والمسرح.

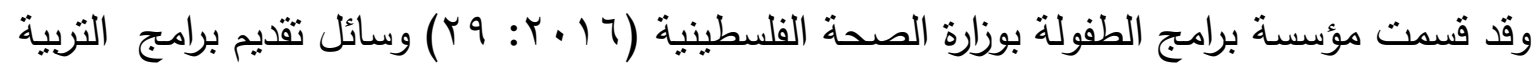
الصحية لتتمية الوعي الصحي للأطفال إلى ما يأتي: - وسائل مقروءة (بسيطة): بتوظيف الجمل والعبارات المكتوبة، مثل: السبورة، ولوحات الإعلانات، والملصقات، والإعلانات، والكتيات الصغيرة، ورسائل الجوال، والصور،

$$
\text { والمعارض. }
$$

- - وسائل مسموعة: بتوظيف الكلام المنطوق، مثل: المحاضرات، والمقابلات، والندوات. - - وسائل مسموعة مرئية: من خلال برامج التليفزيون، برامج على أقراص مدمجة. وهناك عدة دراسات استهدفت تتمية الوعي الصحي للأطفال في مرحلة الروضة من خلال برامج

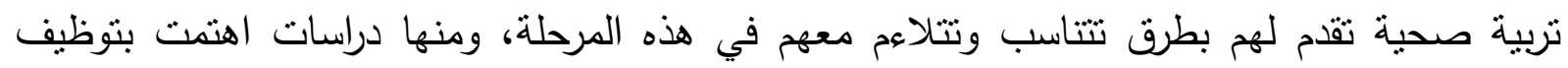

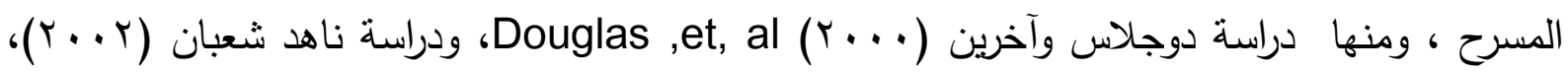

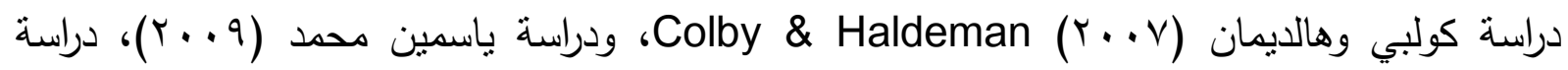

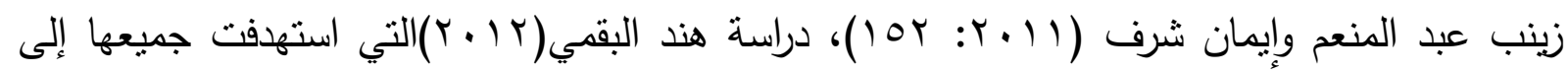

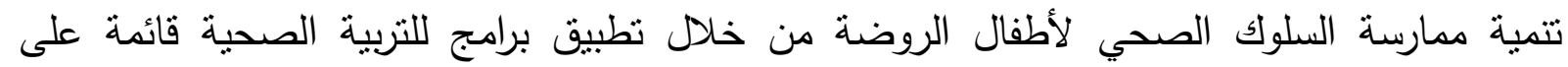

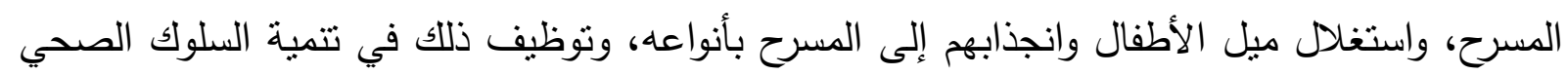
لديهه، وحل المشكلات الصحية التي يعانون منها، وقد أوصوا بأن تقدم برامج التربية الصحية للأطفال

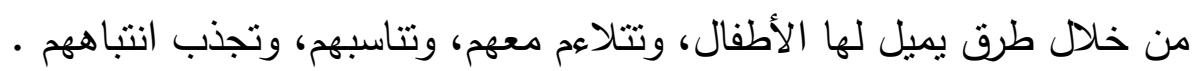

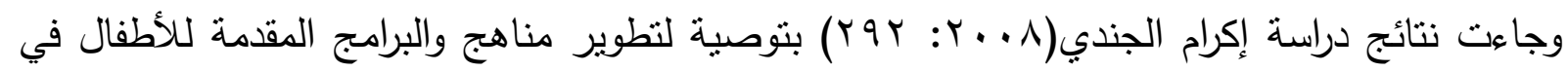
مرحلة الروضة، وذللك بإضافة بعض الموضوعات لتتمية الوعي الصحي، التي تهتم بالسلوكيات الصحية

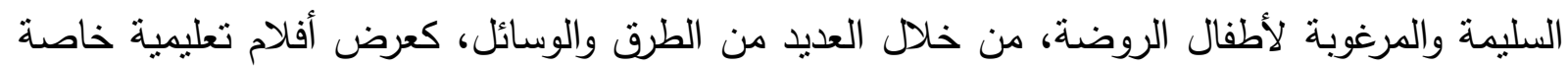


بالبرامج الصحية، ومن خلال نوفير قصص خاصة تهدف للتربية الصحية للأطفال، وتصميم حقائب تعليمية وتتفيذها؛ بحيث تحقق أهداف التربية الصحية، واستخدام وسائل مختلفة لتحقيق ذللك، وكما نادئ تهات بإكساب طفل الروضة الوعي الصحي والممارسة العملية للنظافة الثخصية والسلوك الصحي السليم من وناء خلال ممارسة الأنشطة المحببة والمفضلة في نفوس أطفال هذه المرحلة.

اهتمت دراسة شادية عبد الحميد (r ب ب) بتتمية الوعي الصحي ومهارات التواصل الثفهي(التحدث

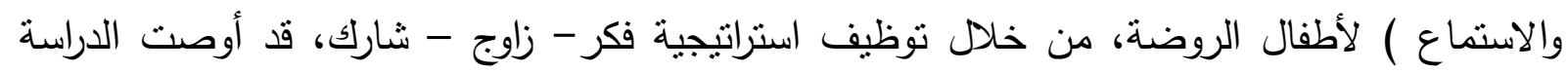

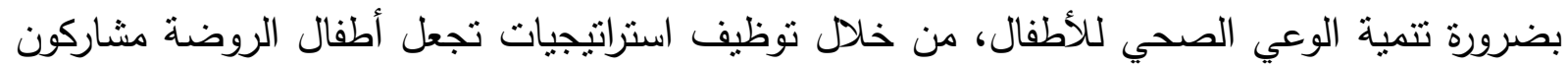
ونشطون في أدائها دائمًا.

أكدت دراسة عامر الأميري وآخرين(乏 ( ب) أثر استخدام التصحيح الزائد في تعديل بعض العادات

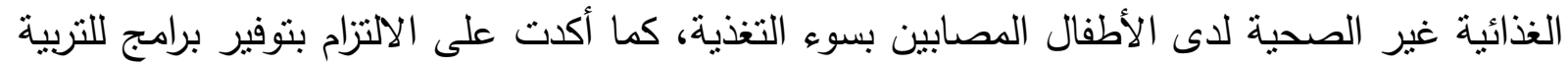

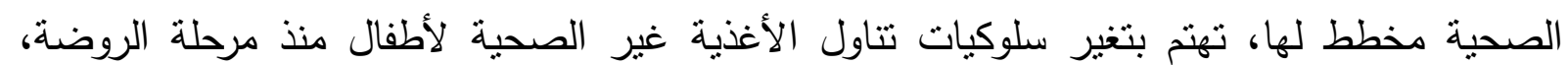

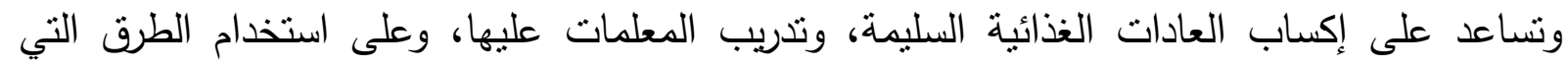

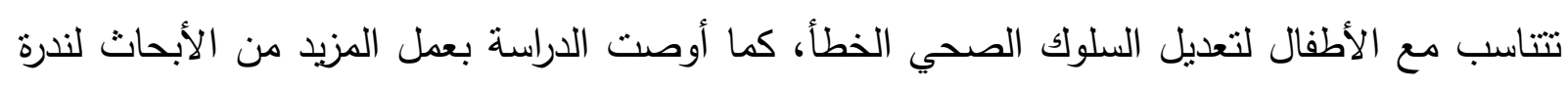
الدراسات في مجال التربية الغذائية الصحية.

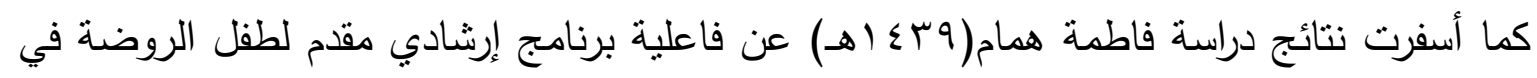

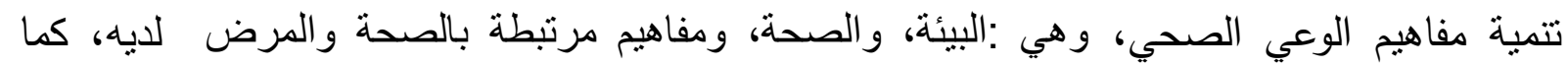

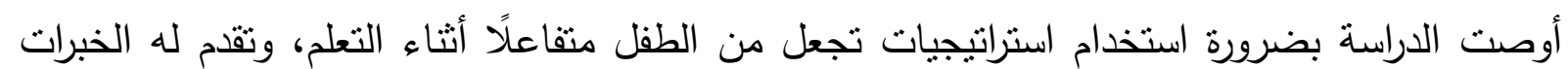
المباشرة، والممارسة العملية لتتمية الوعي الصحي لديه.

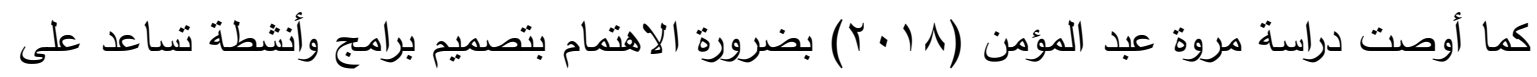

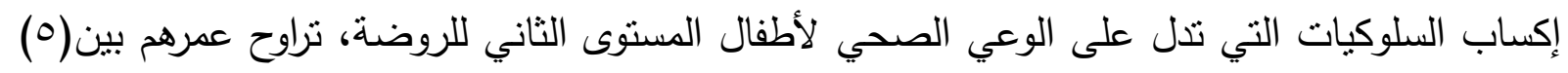

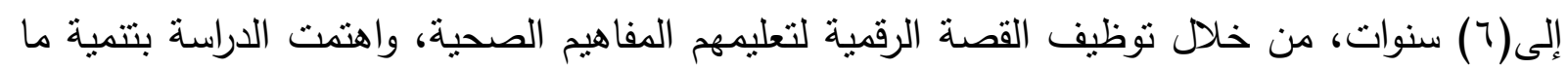
- - النظافة الثخصية لما يأتي: الثعر ، والوجه، والأيدي، والأظفار (الأظافر)، والملبس.

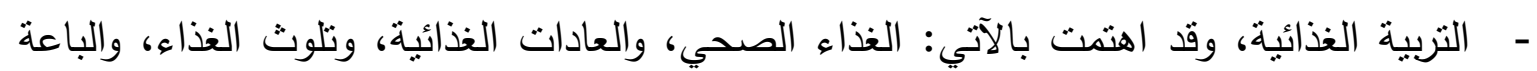

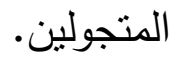
- الوقاية من الحوادث، وطرق الإسعافات الأولية في الأماكن الآتية: غرفة الصف، والبيت، والثارع. 
كما تم الحصول على عدد من الدراسات والبحوث السابقة التي أوصت بضرورة تتمية الوعي الصحي

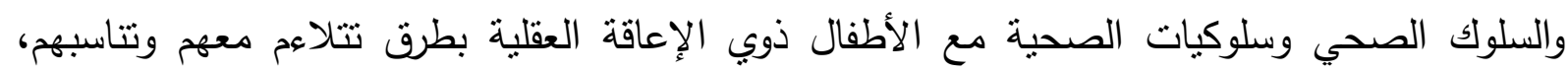

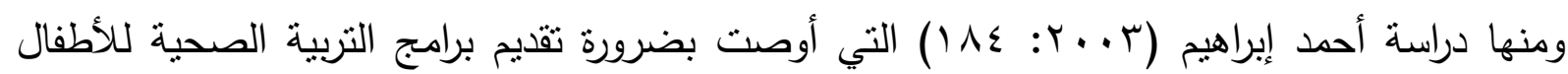

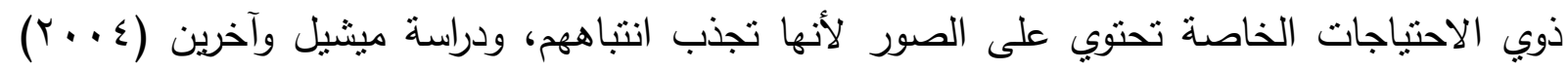
Michael ,et al,

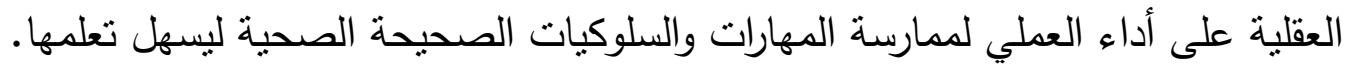
كما اهتمت رقية العباس (ع . . ب) بدراسة فاعلية برنامج للتربية الصحية على الأطفال ذوي الإعاقة

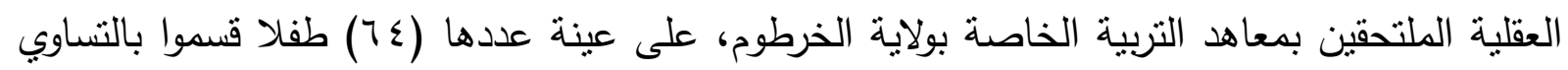

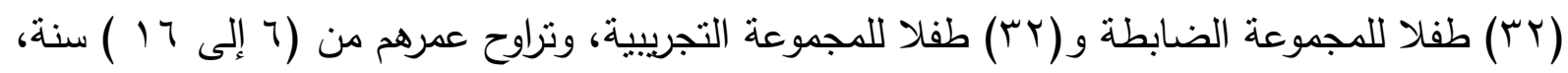
وأثنتت الدراسة فاعلية البرنامج على تتمية السلوك التوافقي وتقدير الذات من خلال برامج التربية الصحية ولتهرية

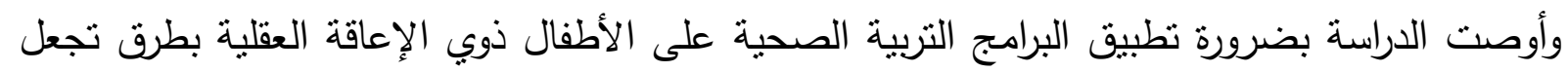
الطفل يمارسها بشكل عملي لتنبيت السلوكيات الصحية لديه.

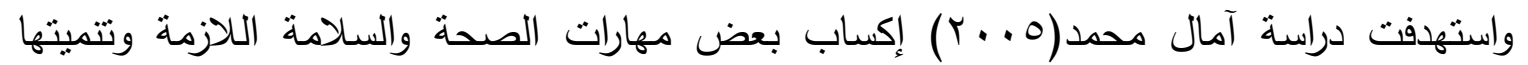
لأطفال ذوي الإعاقة العقلية البسيطة بسلطنة عمان، قائم على جداول النشاط المصورة والمكتوبة، وكانت

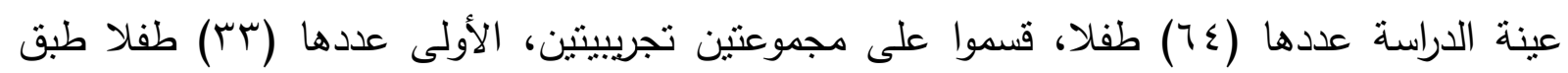

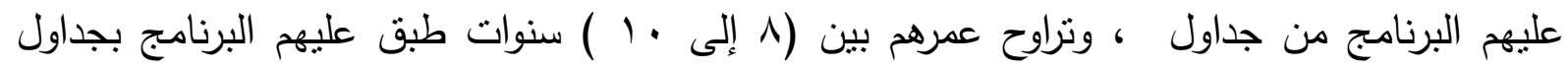

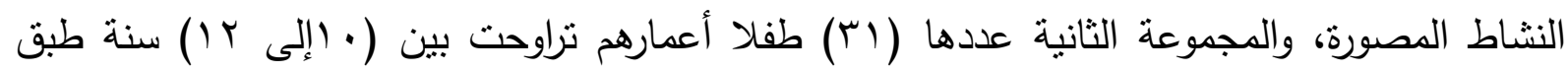

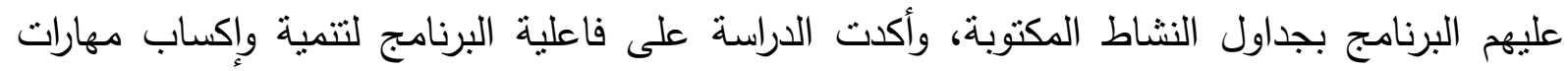
الصحة والسلامة للأطفال ذوي الإعاقة العقلية، وأوصت بعمل مزيد من الدراسات لنتمية السلوكيات الصحية لهم.

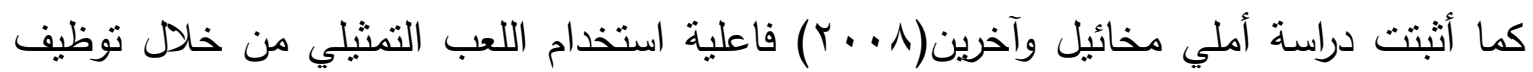
مجموعة من الأنشطة الفنية والموسيقية والقصصية مع الأطفال ذوبي الإعاقة العقلية البسيطة لتنمية

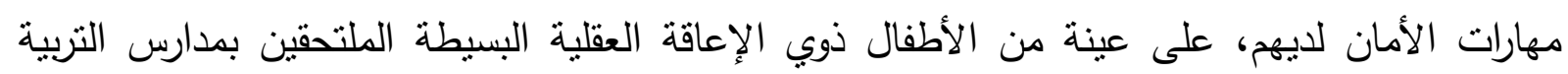

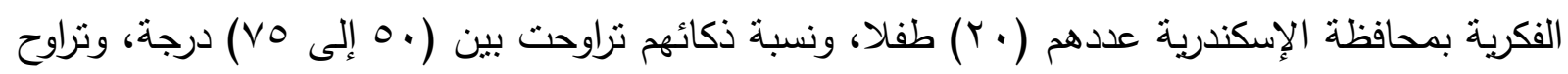

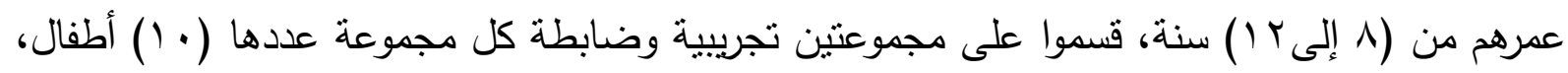

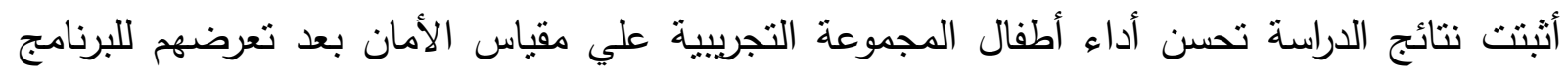

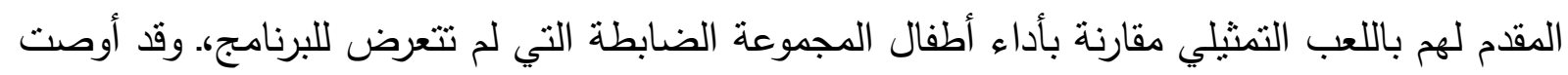

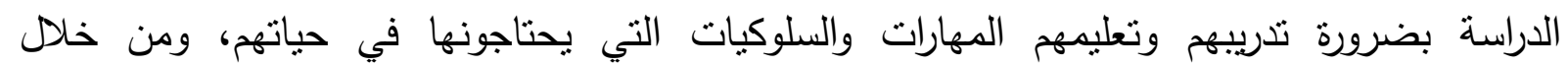

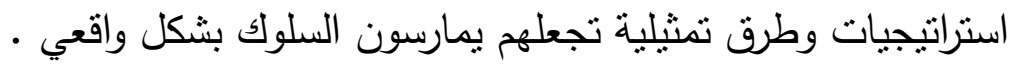




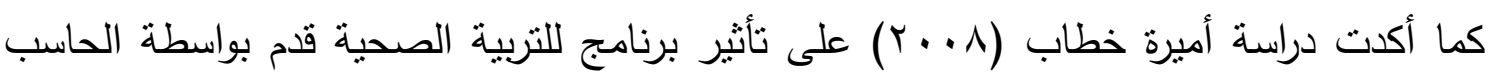

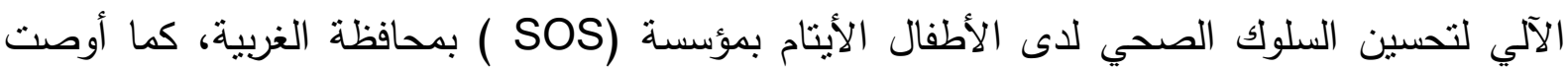

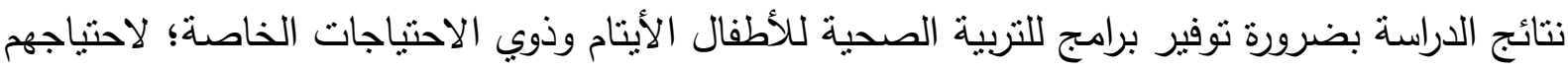
الثنديد لمنل هذه البرامج، وبطرق تراعي الفروق الفردية بينهم، وتحبيهم في ممارسة السلوك الصحي.

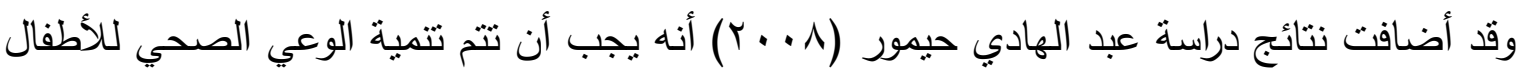
فئة ذوي الإعاقة العقلية ببرامج للتربية الصحية التي تقدم بطرق تتوافق مع خصائصهم، وتلبي احتباجاتهم

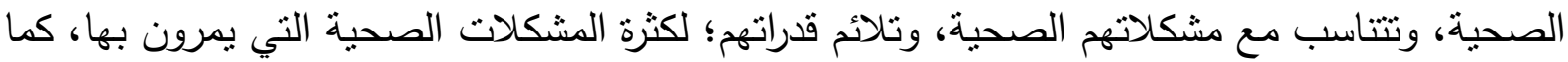
أن تقديم برامج التربية الصحية لتتمية الوعي الصحي لديهم يعين المعلمات على إكساب هؤلاء الأطفال السلوكبات الصحية، كما بعين الأطفال على سهولة ممارستها. وقد أكدت دراسة سمير عقل وقيس عصفور (10 ب ب) على فاعلية برنامج في العلوم قائم على التعليم المعزز بالحاسوب في تتمية الوعي الصحي للأطفال ذوي الإعاقة العقلية البسيطة الملتحقين بالمرحلة

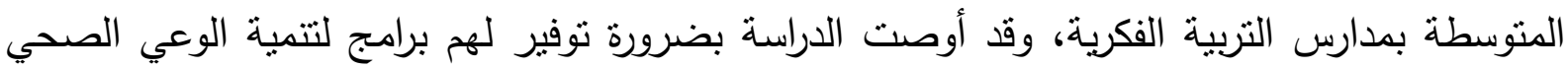

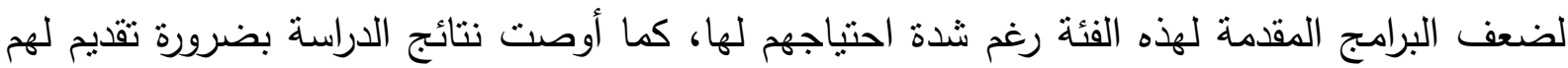
هذه البرامج بطرق تتتاسب معهم.

ومن خلال العرض السابق بتضح أنه بالرغم من تعدد الدراسات التي تم الحصول عليها التي اهتمت الته

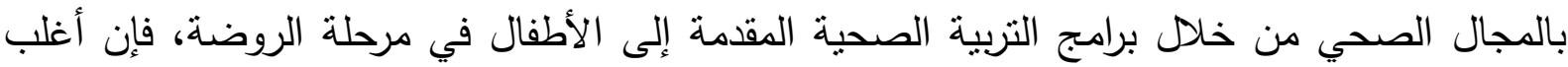

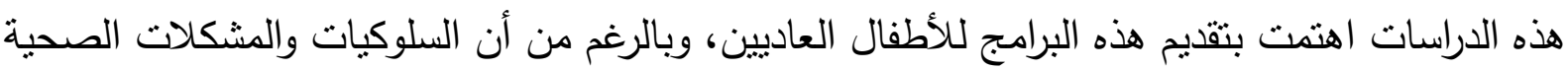
لأطفال الروضة ذوي الإعاقة العقلية البسيطة والملتحقين بروضات التربية الفكرية أثند صعوبة وأكثر

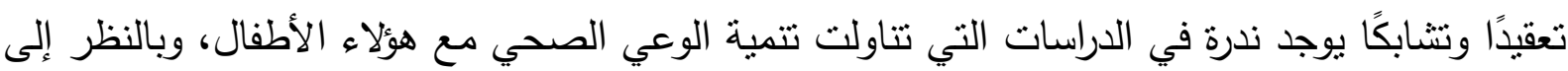
واقع البرامج المقدمة لأطفال الروضة الملتحقين بروضات التربية الفكرية فمازالت هذه البرامج تتجاهل

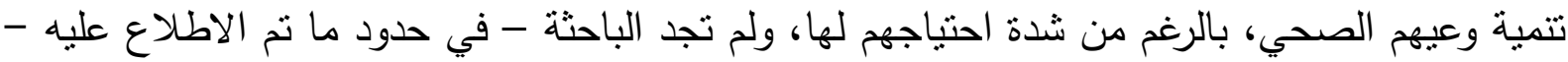

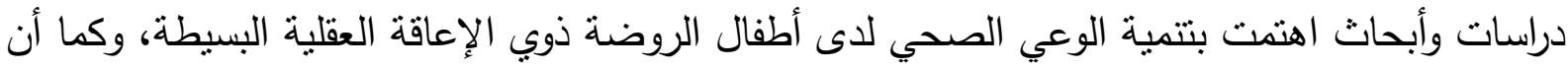
أغلب الدراسات التي نتاولت برامج التربية الصحية تتاولتها من جانب حصر المشكلات الصحية التي

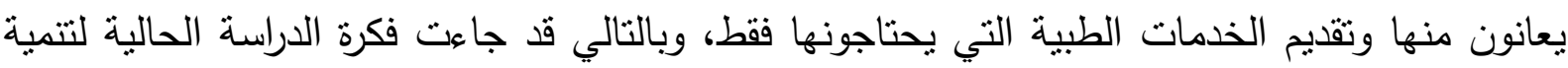
الوعي الصحي لهؤلاء الأطفال.

ومن خلال عمل الباحثة مع أطفال الروضة بالتربية الفكرية في بداية حياتها العملية، ومن خلال

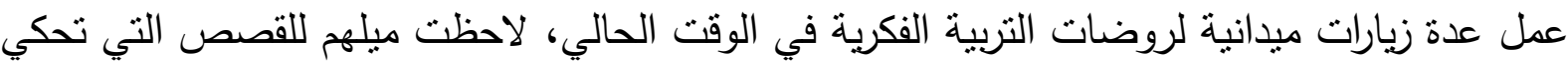

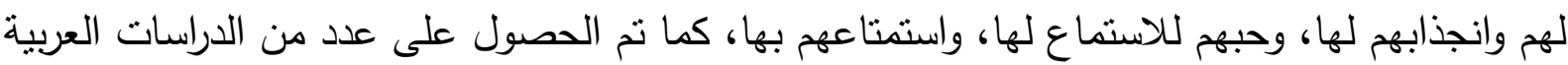

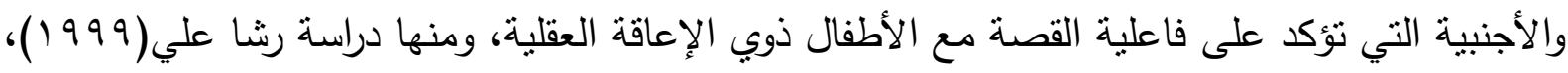




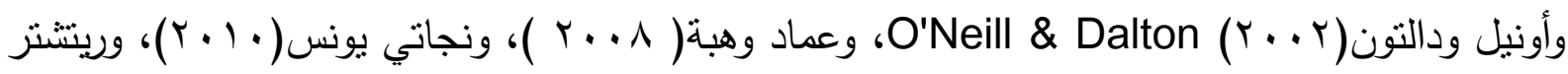

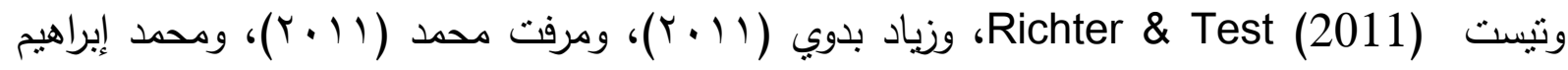

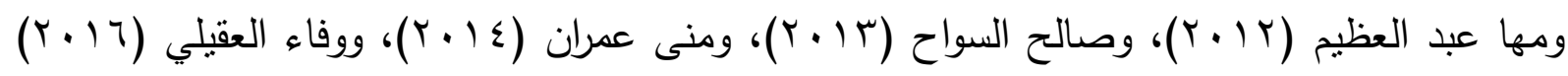

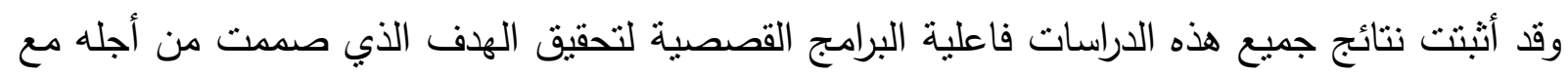
الأطفال ذوي الإعاقة العقلية، وسوف يتم تتاول القصة بالمحور الثاني للارسة.

\section{المحور الثاني : القصة لأطفال الروضة ذوي الإعاقة العقلية البسيطة:}

للقصة حيز كبير في جميع الكتب السماوية منها مزامير داود، وتوراة موسى، وإنجيل عيسى، وأخيرًا القرآن الكريم، ولقد وظفت القصة للعبرة والعظة لأثرها على نفوس وعقول البشر ؛ لدورها التربوي الكبير

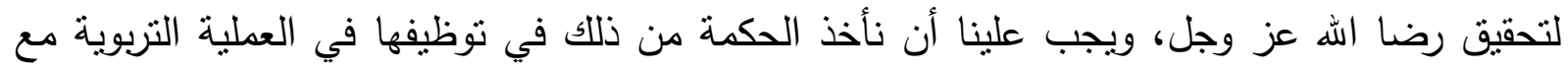
الأطفال لتعديل سلوكهم، وخفض حدة مشكلاتهم التي يعانون منها، وإكسابهم العديد من السلوكيات

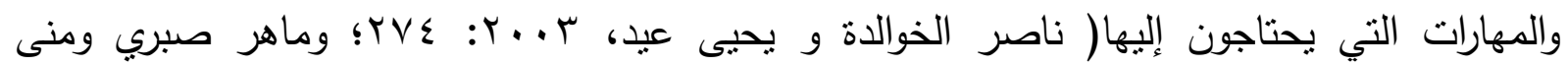

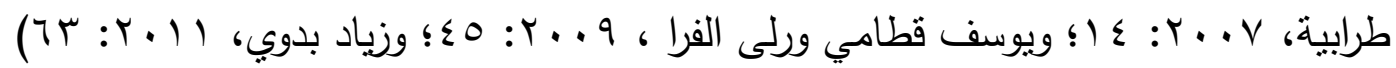
إن جميع الأطفال يميلون بفطرتهم إلى سماع القصص؛ فللقصة مكانة هامة في حياة ونفوس

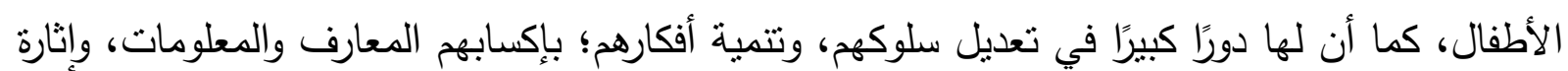

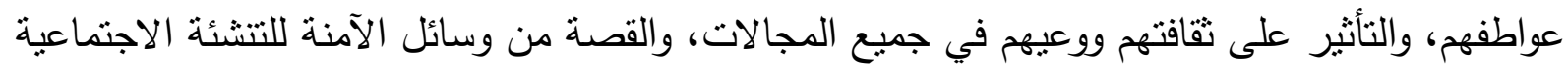

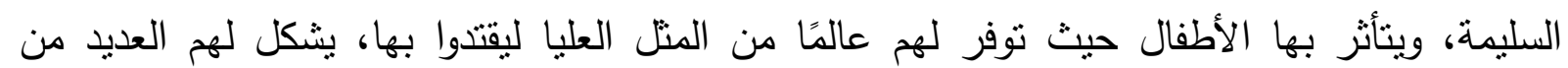
الأفكار، ويكون لهم الاتجاهات الإيجابية الصحيحة؛ ولذلك تعد القصة من أهم وأقدم فنون الأدب لهاب

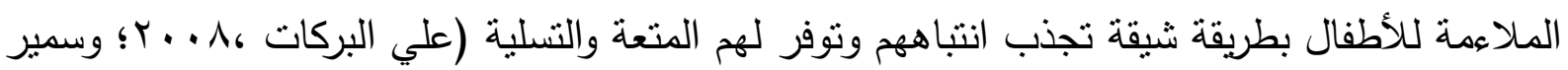

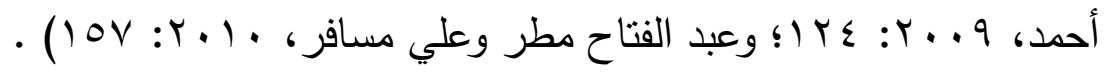

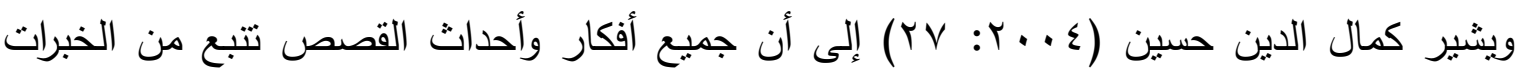

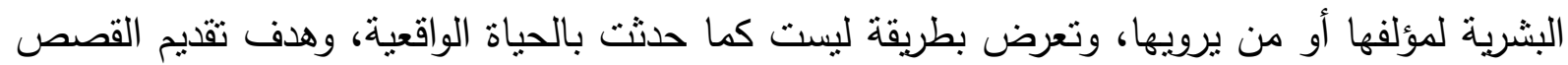
للطفل هو إكساب الطفل الدروس المستفادة منها.

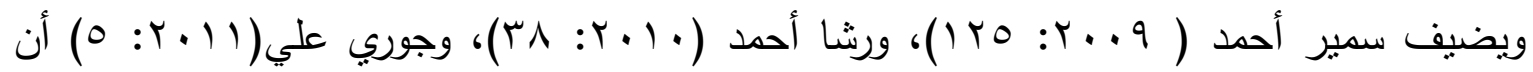
القصة تعمل على توجيه وإرشاد وإكساب الطفل السلوك المرغوب فيه بطريقة غير مبانرة، وبطرق ممتعة

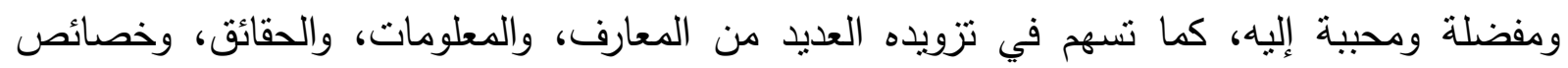
الأثشياء، والمفاهيم، التي يحتاجها في حياته.

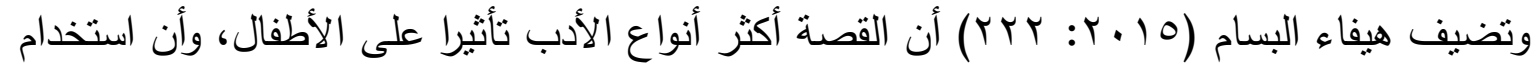

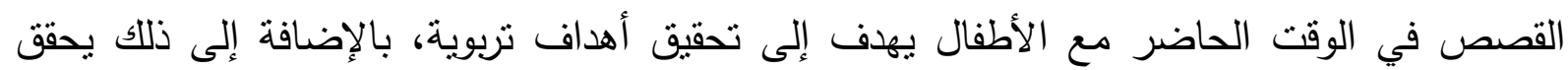


التقارب الثقافي والحضاري؛ فيتعرف الطفل على التنوع والاختلاف، كما تساعد القصة الطفل على تقبل الآخرين، كما أوصت دراستها بضرورة استخدام القصص مع الأطفال.

كما هدفت دراسة عماد وهبة( ^ · ب ) إلى تقديم تصور مقترح لكيفية تطوير مدارس التربية الفكرية

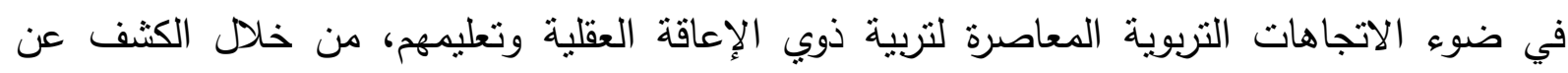
جوانب القصور في عناصر العملية التعليمية في مدارس التربية الفكرية بمحافظة سوهاج، وتم ذلك بإجراء استطلاع لرأي ( FV ) من أولياء الأمور، والمعلمين، والمدراء، والموجهين التربويين، والأخصائيين

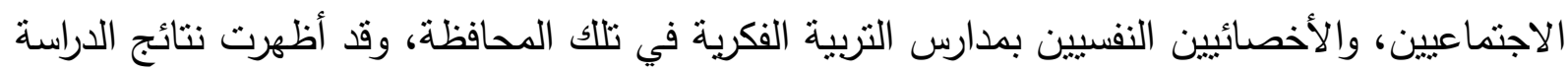

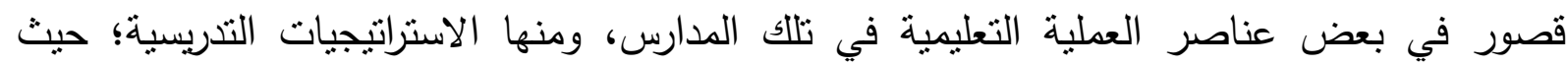
أظهرت نتائج الدراسة عدم اتجاه المعلمين إلى استخدام استراتيجيات تساعد في تعلم الأطفال ذوبي الإعاقة العقلية وتعلمه بشكل فعال، كما أوصت الدراسة بضرورة توظيف الاستراتيجيات التنريسية التي تلبي احتباجاتهم، ويميل إليها الأطفال ذوو الإعاقة العقلية، ومنها القصة. r- r- r- تعريفات القصة نعرض منها ما يأتي: يعرف حسن شحاتة (1991: 9 § () القصة بأنها "حكاية تقوم على الأحداث، والصراع، والعقدة، والحل، والثخوص، والزمان، والمكان، والهدف المنوط بها هو الإمتاع والتسلية".

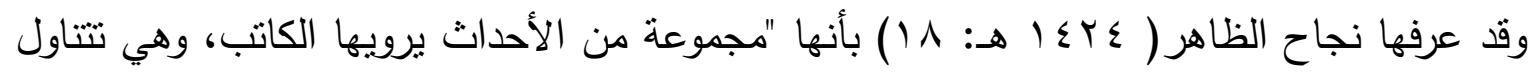

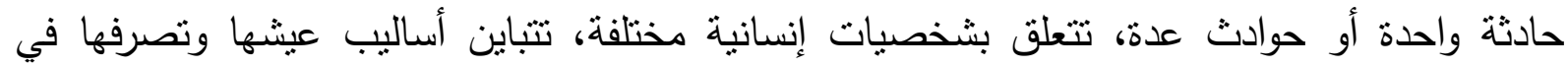

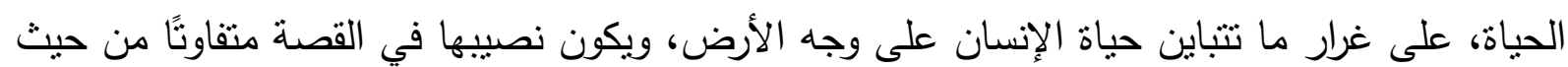

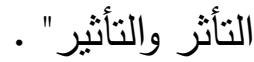

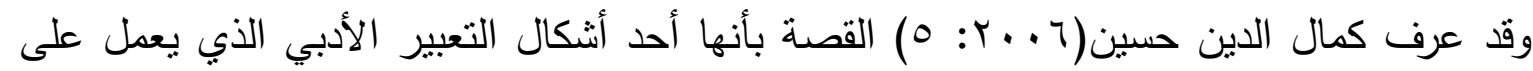
نقل خبرة من الحياة ومن الواقع، يصيغها الكاتب والأديب من خلال خياله المبدع، في صورة تعيد تثكيل الواقع في صورة جديدة، تعبر عن وجهة نظر الكاتب تجاه الخبرة الحياتية التي يريد نقلها إلى القارئ؛ من فن فئه أجل تحقيق هدف وجداني ثقافي معرفي، ووسيلته في ذلك الكلمة المكتوبة.

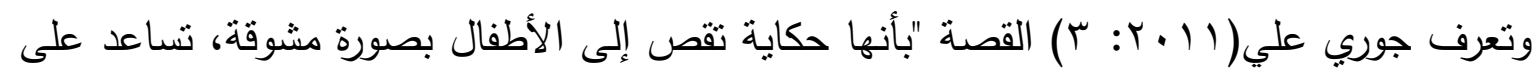
تقريب المفاهيم التي تهنم بها التربية، وتبرزها بصورة شخوص إنسانية أو كارتونية أو حيوانية".

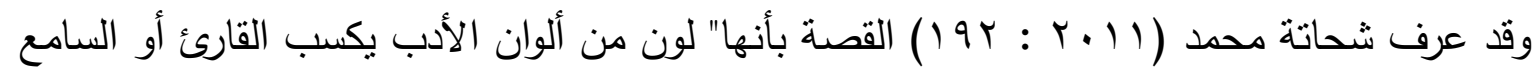
بعض القيم، والعادات، والتقاليد، والمعارف، والخبرات التعليمية، وتتمية الفرد عقليًا وعاطفيًا واجتماعيًا

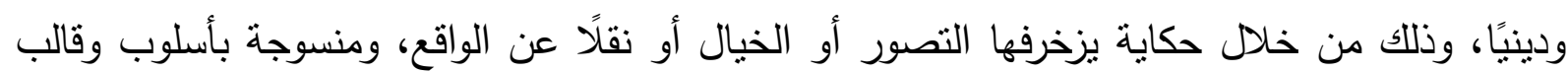

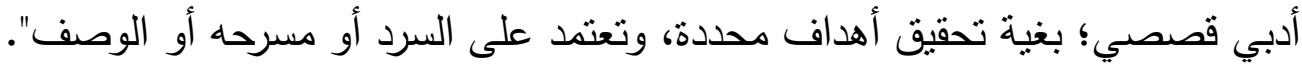




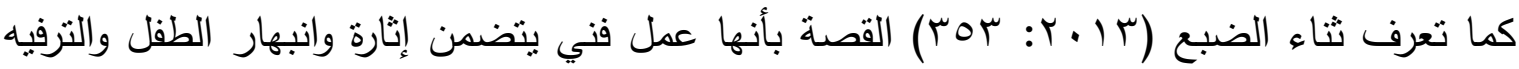

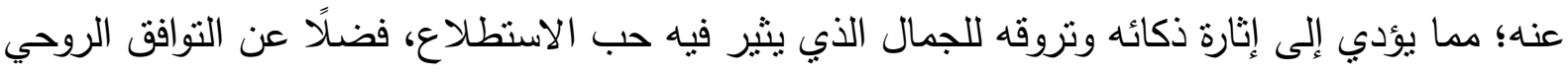
والنفسي.

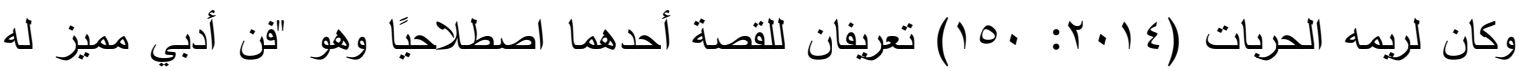
قواعده ولاسيما يمكن خلاله نقل المعارف، والتأثير في المشاعر ، والانفعالات من خلال مجريات متتابعة

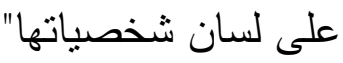
والتعريف الأخر تربويًا " هي أسلوب تعليمي تعلمي يعتمد شكلًا فنيًا أدبيًا، لتحقق أهداف معينة لدى المتعلمين، يرافقه إجراءات وأنشطة تكمل وتحقق ما يرجى منها".

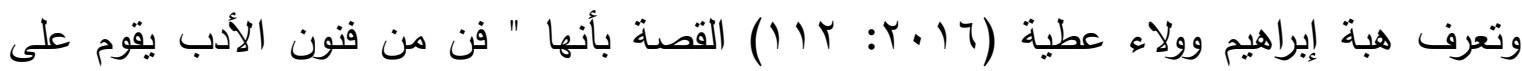

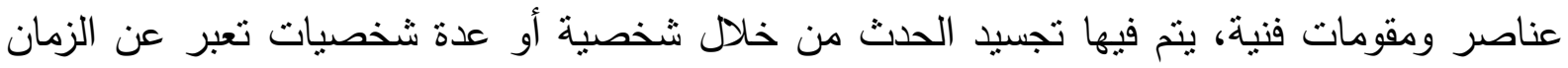

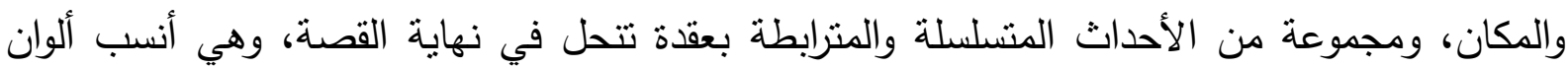
الأدب للطفل؛ حيث تقدم له المعرفة في جو من الإثارة والمتعة". وتعرف كل من فاطمة شعبان وفايزة يوسف (1) • r: ror) القصة على أنها "عمل فني يمنح الثعور بالمتعة والبهجة، كما يتميز بالقدرة على جذب الانتباه والتشويق، وإثارة الخيال، وقد يتضمن غرضيًا

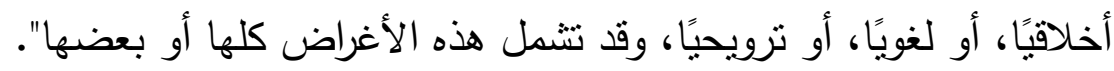
من خلال العرض السابق يتضح ما يأتي: - - القصة شكل من أشكال الأدب، ينقل من خلالها مؤلفها أو راويها خبراته للمتلقي.

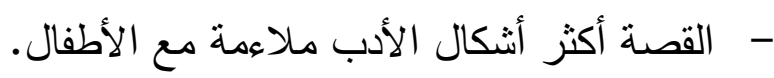
- تكسب القصة السلوك الصحيح، والعادات، والتقاليد للأطفال. - تكسب القصة معلومات، ومعارف للأطفال. - تحقق القصة تتمية للمهارات اللغوية، والاجتماعية، والنفسية للأطفال. - - لها دور كبير في تتمية القدرات العقلية للأطفال. - أن القصة تحقق المتعة، والتسلية، والتزفيه بطريقة شيقة، وجذابة للأطفال. - تتكون القصة من شخصيات، وأحداث، وعقدة، وزمان، ومكان. - أثخاص القصة قد تكون إنسانية، أو حيوانية، أو خيالية، أو كرنونية. وتعرف القصة إجرائيًا بأنها مجموعة من الأحداث البسيطة المتعاقبة الثيقة التي تجذب انتباه

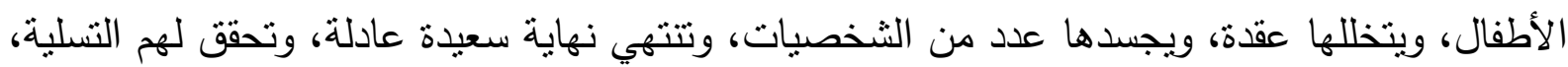
والتزفيه، والمتعة، لتتمية الوعي الصحي لأطفال الروضة ذوبي الإعاقة العقلية البسيطة. 
r-r- أهمية القصة لأطفال الروضة:

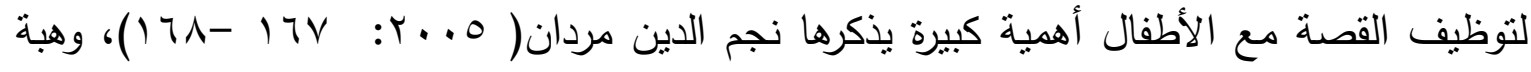

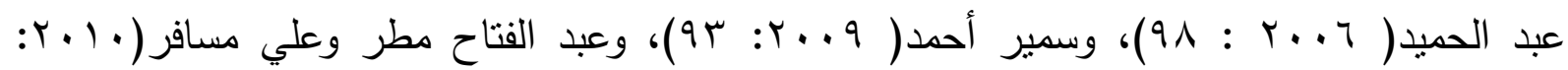

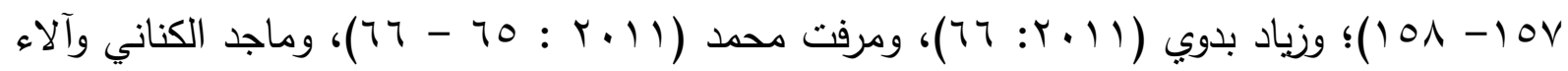

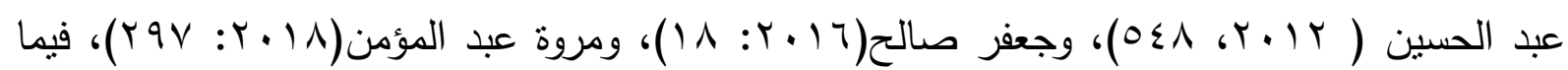
يأتي : - تسهم في اطلاع الأطفال على العديد من المعلومات، والمعارف، والحقائق في العديد من المجالات، بطريقة شيقة تجذب الانتباه.

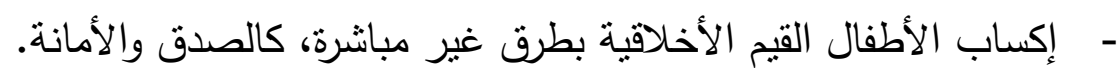

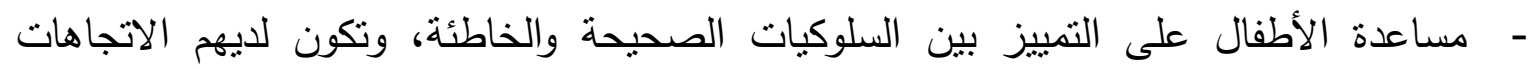
السليمة نحو السلوكيات المرغوبة، وإكسابهم السلوك السوي، وفهم السلوك الإنساني وتفسيره . - - تشكل حب الوطن لاى الأطفال، وانتماءهم له. - إكساب الأطفال الطرق الصحيحة لحل المشكلات التي يمرون بها في حياته، من خلال عرض الهان مشكلات مماتله في أحداث القصة، وتقديم حلول لها.

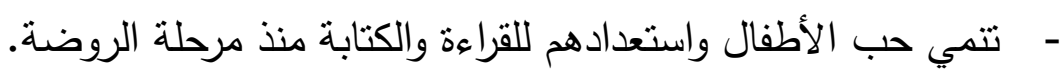
- ت تمية المهارات اللغوية للطفل كالتحدث، والاستماع، وزيادة حصيلة المفردات لديه. - - نوفر لدى الأطفال الثعور بالمتعة، والتسلية، والفكاهة أثثاء العملية التعليمية، والبعد عن الرنابة والملل .

- تتمي الخيال لدى الأطفال، من خلال (طلب من كل طفل وضع نهاية للقصة). - - تسلسل أحداث القصة وتدرجها يساعد على تتمية التفكير المنطقي لايهر.

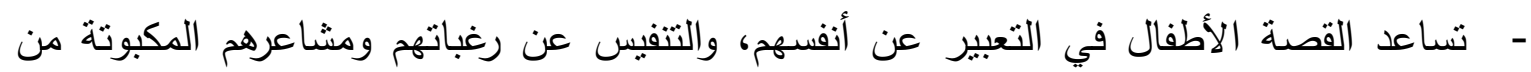
خلال شخصيات القصة، وتتوعها، وتقصهم لها. - مساعدة الأطفال على التواصل مع الآخرين، وتكوين علاقات اجتماعية سليمة مع من حولهم. - تتمية الدفاهيم العلمية لاى الأطفال من خلال تقديم القصص عن الإنسان والحيوانات والطيور . - ت تمية التذوق للفنون الأدبية لدى الأطفال منذ مرحلة الروضة.

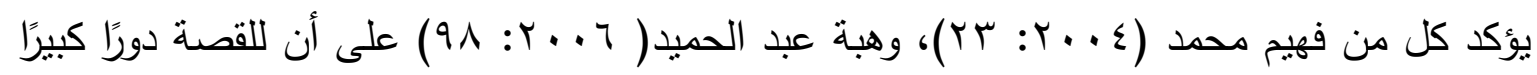
في قدرتها على معالجة المشكلات التي يمر بها الطفل ويعاني منها في حياته اليومية، من خلال تقديم 
حلول على لسان أبطالها، فيتوحد الطفل مع أبطالها ويساعده ذلك في إكسابه الخبرات، والعادات، والسلوكيات الإيجابية التي يحتاجها.

كما تثير مارجوت صاندرلاند (0. . r: ؟ ؟-7؟) إلى أن القصة تعد من الاستراتيجيات التربوية

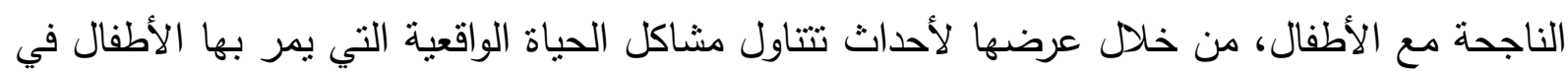

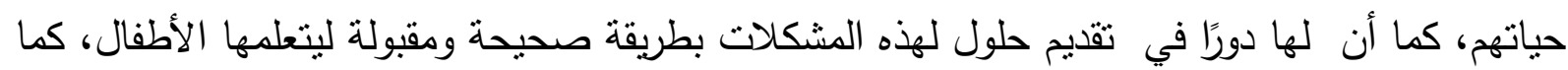

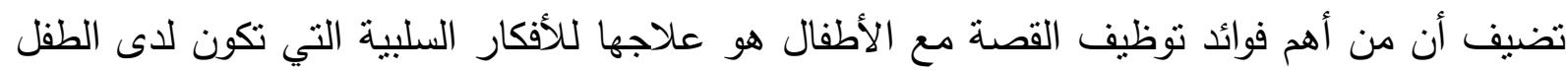
تجاه نفسه، مثل :أنا غبي أو لا يحبني أحد، كما قد تتجع القصة الطفل على الرسم والتلوين والإبداع.

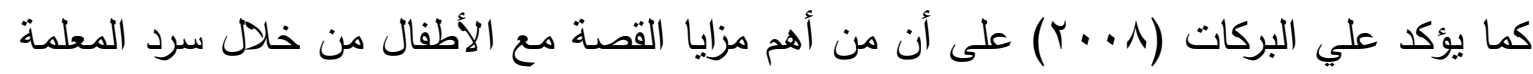
القصة للطفل تحويل الكلام المنطوق والمسموع إلى صور ذهنية خيالية لديه نتمي قدرته على الخيال التيال

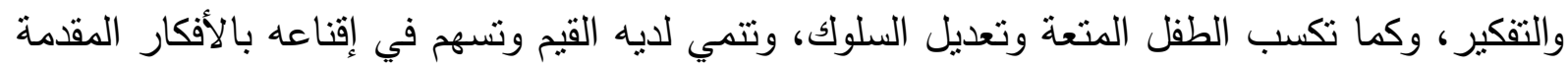

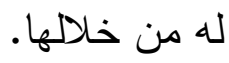

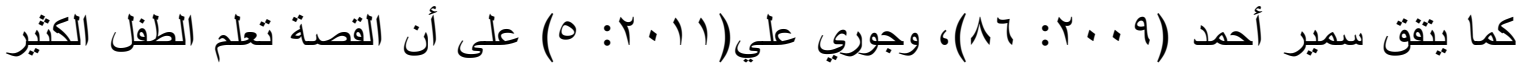

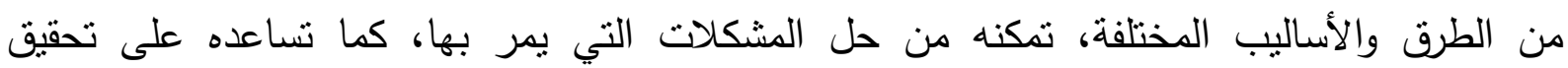
السلامة، والأمان، وللنجاة من العديد من الأخطار، والمآزق التي قد يمر بها.

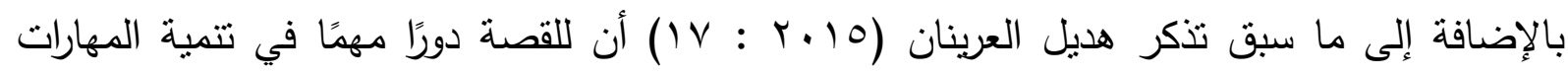
اللغوية للأطفال، ومنها التحدث والاستماع؛ لأنها تدرب الطفل على الإنى الإنصات واستخدام المفردات اللغوية

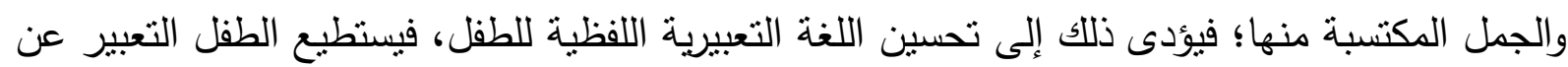

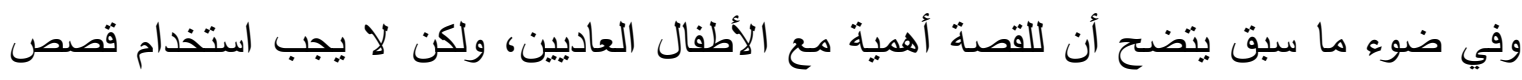

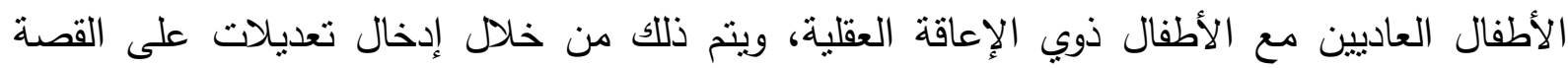

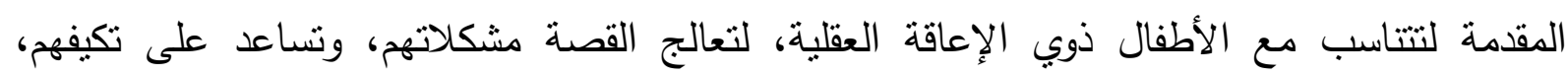

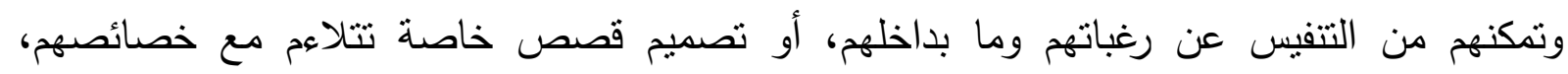

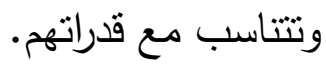

ولم تجد الباحثة - في حدود ما تم الاطلاع عليه - غير القليل من الأدبيات والأبحاث والدراسات

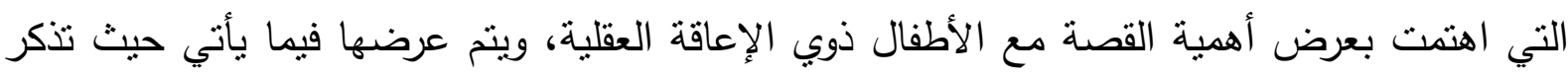

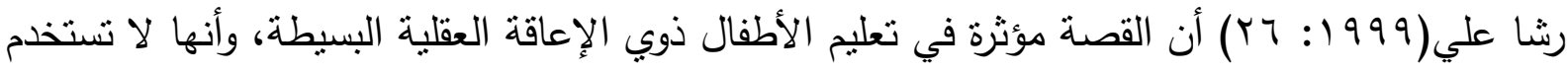

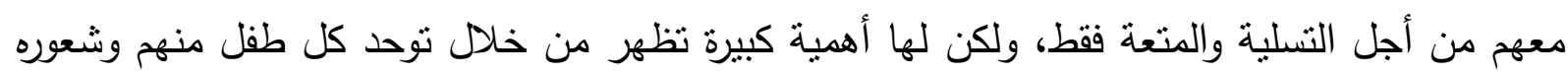




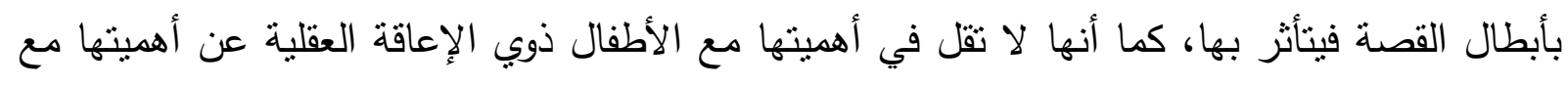

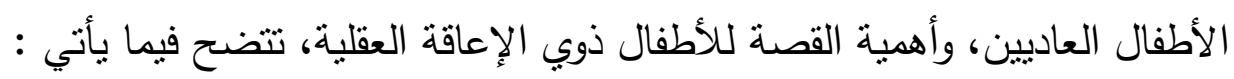

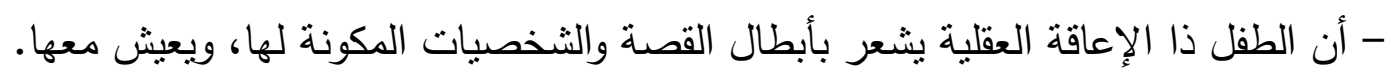

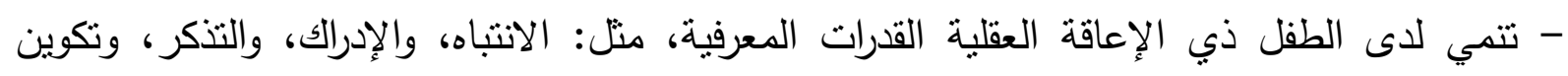
• المفاهيم

- تساعد القصة على تتمية المهارات اللغوية لدى الطفل ذي الإعاقة العقلية.

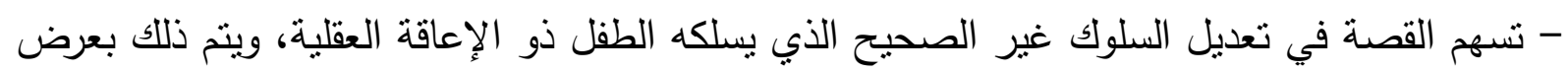
السلوك الصحيح من خلا أبطال القصة بصورة محببة ومفضلة، كما تعرض القصة السلوك الخطأ بصورة منفرة لينفر منها الطفل ذو الإعاقة العقلية.

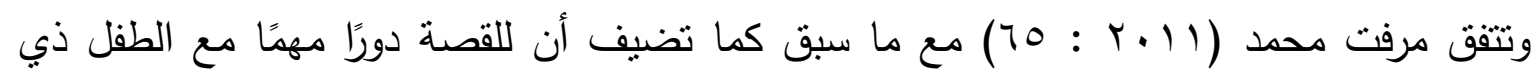

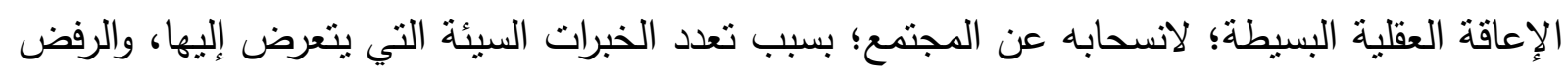

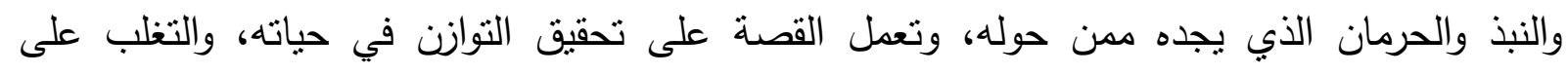

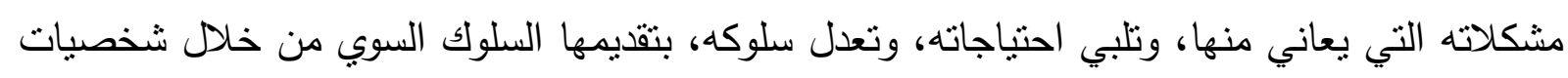
وأبطال القصة.

ومن خلال العرض السابق ترى الباحثة أن أهمية توظيف القصة في مجال الإعاقة العقلية، تنقسم إلى ما يأتي:

\section{1. أهمية توظيف القصة بالنسبة للأطفال ذوي الإعاقة العقلية البسيطة:}

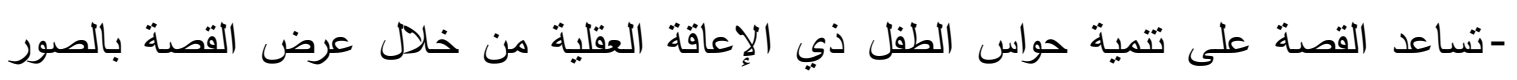

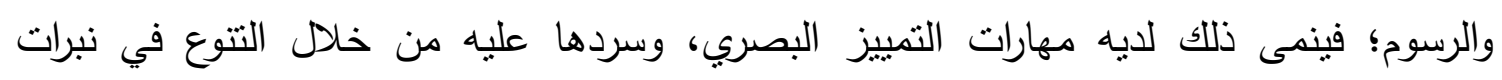

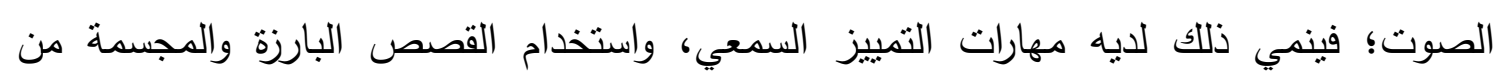

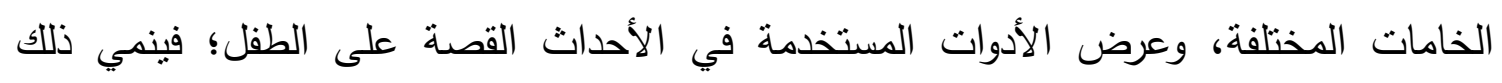
مهارات اللمس لديه. - إكساب الطفل ذي الإعاقة العقلية العديد من المهارات اللغوية من خلال تتمية مهارات الاستماع،

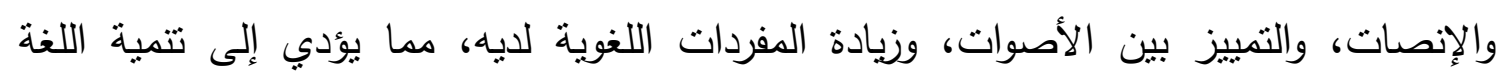
التعبيرية الثفهية، والتحدث، وعلاج الششكلات اللغوية التي قد يعاني منها. - تتمية المهارات العقلية لاى الطفل من خلال تتمية مهارات التفكير في تسلسل أحداث القصة، وتتمية مهارات التزكيز الانتباه من خلا عرض القصة، وتتمية مهارات التذكر والإدراك لأحداث

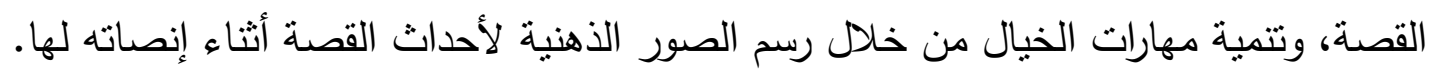


- تسهم القصة في توجيه السلوك الاجتماعي للأطفال ذوي الإعاقة العقلية، من خلال تحقيق التعاون والمشاركة بينهم.

- توجه القصة السلوك الانفعالي للطفل ذي الإعاقة العقلية، ومن خلال تعليمه طرق التعبير عن مشاعره في الأوقات المختلفة أثناء الفرح، والحزن، والخوف، والغضب. - تتمية إحساس الطفل ذي الإعاقة العقلية ومشاعره بنفسه، ومشاعره، وإحساسه بالآخرين سواء كانوا أشخاص، أم حيوانات، أم طيور ، والتعاطف معهم. إن. - إثراء الطفل ذي الإعاقة العقلية بالمعلومات والمعارف عن ما يحيط به، وتكوين المفاهيم التي يحتاجها الطفل في حياته.

r. أهمية توظيف القصة بالنسبة لمعلمة الأطفال ذوي الإعاقة العقلية: - تكوين علاقة تواصل اجتماعي إيجابية بين المعلمة والطفل ذي الإعاقة العقلية. - تساهم المعلمة في تكوين علاقات تواصل بين الأطفال وبعضهم، من خلال طلب منهم التعاون في تمثيل القصة بعد سماعها.

- تساعد القصة المعلمة في اكتشاف الابتكار لدى الطفل ذي الإعاقة العقلية وتتميته؛ من خلال حث الطفل على وضع نهاية للقصة، أو إعطائه فرصة لرسم وتلوين أبطال القصة، أو أحداثها حسب قدراته.

- تساعد المعلمة في تحويل الأفكار السلبية التي لدى الطفل لذاته، ومنها : أنا متخلف، وإحساسه الدائم بالنبذ والرفض، إلى أفكار إيجابية لذاته، وتقبله لنفسه، ودعم الثقة بنفسه، والثعور بالأمان والأمن.

r. أهمية توظيف القصة في العملية التعليمية في مجال الإعاقة العقلية: - استخدام القصة يساعد في القضاء على الملل داخل العملية التعليمية، وتحويله إلى وقت نسلية ومتعة.

- توظيف القصص لإكساب الطفل ذي الإعاقة العقلية المهارات الحياتية التي يحتاجها. - تحقق جذب انتباه الأطفال، ويظهر ذلك من خلا حب الأطفال للوقت الذي يقضونه أثناء الإنصات للقصة.

- التسلسل في أحداث القصة بالتدريج يقنع الطفل بالأفكار التي تدور حولها القصة. - استغلال القصة في تقديم حلول للمشكلات التي تواجه الطفل ذا الإعاقة العقلية ، بطرق صحيحة ومقبولة اجتماعيًا.

- تساهم القصة في تعديل سلوك الأطفال، وتقديم السلوك السوى، من خلال أبطالها مع دعمه بالثناء والمدح؛ فيحاكيها الطفل ذو الإعاقة العقلية ، ويقلدها. - للقصة دور كبير في بناء سلوك إيجابي جديد، ونتكيله. 


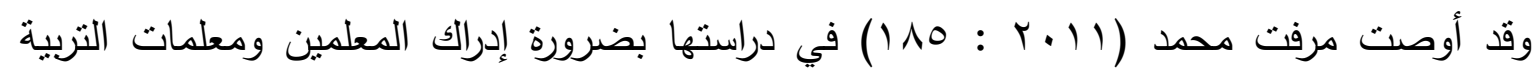

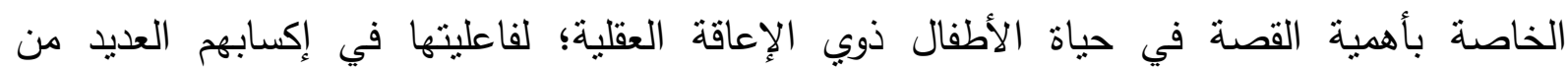

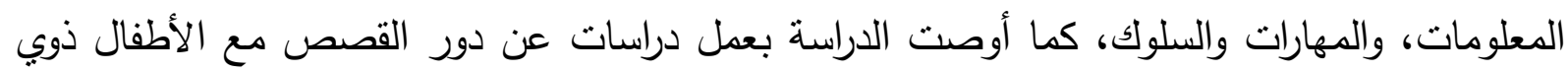
الإعاقة العقلية ، وفاعليتها. r-r- معايير القصة المقدمة للأطفال ذوي الإعاقة العقلية البسيطة:

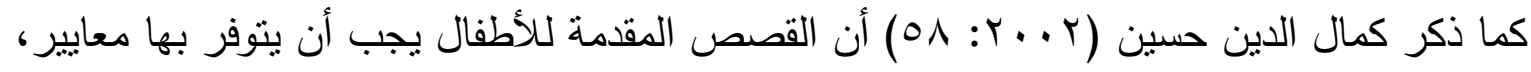
وهي كالآتي:

- - أن تتناسب فكرة القصة مع واقع حياة الطفل الذي يعيشه . - - أن تدور أحداث القصة حول خبرات الطفل الواقعية الحياتية. - - أن تكون أحداث القصة، وحبكتها، وعقدتها متسلسلة، ومتتابعة تتابع منطقيًا.

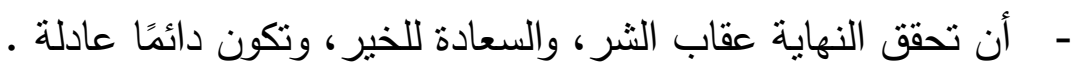
- أن يتوفر فيها إثارة خيال الطفل، ونتتاسب مع واقع حياته.

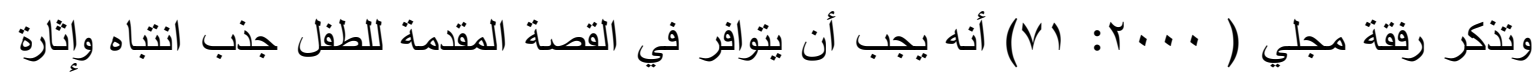
اهتمامه؛ فتجعله يتفاعل مع أحداث القصة فتحرك مشاعره، وتثير انفعالاته منذ بدء أحداثها إلى نهايتها؛

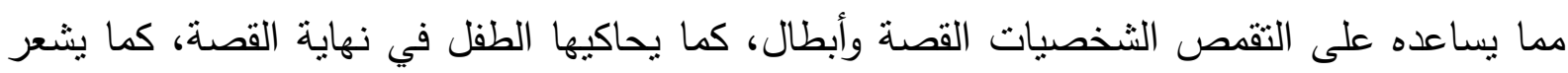
الطفل براحة نفسية نتيجة حل العقدة القصة، وييقى نأثير القصة على الطفل فترة من الزمن، ويقلد الطفل سلوك الثخصيات المحبية له فيها.

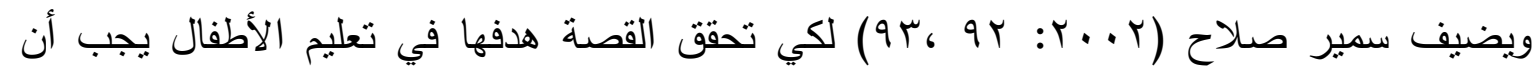
يتوفر بها مجموعة من المعايير والثروط، وهي ما يأتي: - - أن تكون القصة مناسبة للأطفال المقدمة لهم. - - - أن ترتبط القصة بموضوع الدرس المقدم للأطفال . -

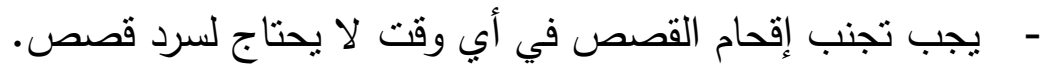

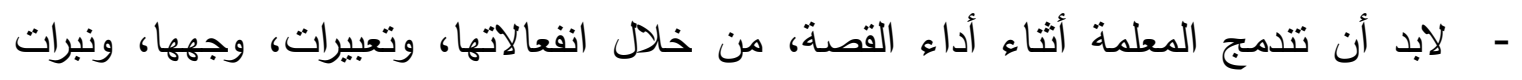
صوتها. - - يجب توظيف الوسائل المعينة في تقديم القصة للأطفال. - - الابد من مناقتشة الدروس المستفادة من القصة. -

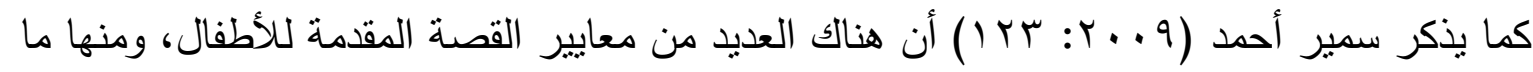


- - اختيار القصة المقدمة للأطفال في ضوء المرحلة العمرية لهم. - - تهيئة المكان المقدم به القصة للأطفال. - - المعلمة قادرة على تقديم القصة للأطفال.

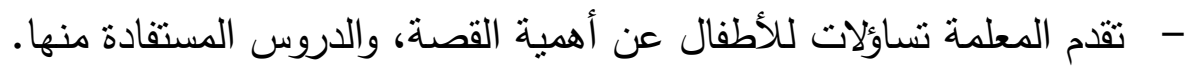
- أن تقلد المعلمة بعض الأصوات الموجودة في القصة مثل البرق والرعد .

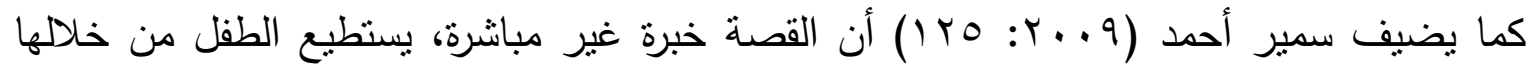
تعلم وتعليم ما في الحياة من خير وشر، والتمييز بين الجميل والقبيح، كما تكسب الطفل القدرة على التفكير واتخاذ القرار؛ مما يساعد على تكوين شخصيته بشكل إيجابي، ونوجيه سلوكه، وذلك يتم عن

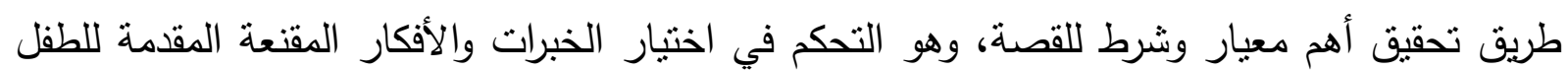

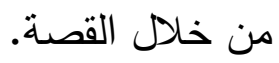

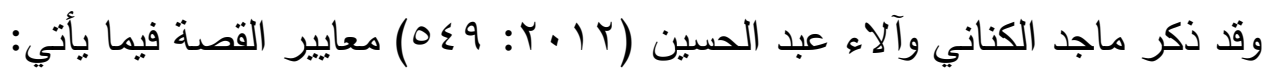

- لها فكرة بها معنى، وفي الوقت نفسه تحقق المتعة والتسلية. - - أن تكون القصة مناسبة لمستوى الطفل، وعمره. - - مناسبة القصة للبيئة الني يعيش فيها الطفل.

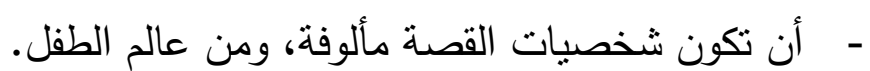
- عدد شخصيات القصة قليلة؛ ليتمكن الطفل من التركيز . - متوفر أحداث تقوي خبال الطفل.

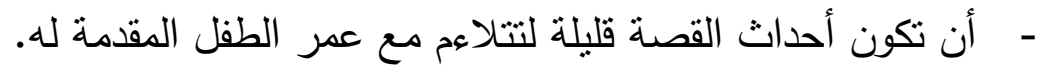
- - تحقق نهاية سعيدة، وعادلة لأبطالها.

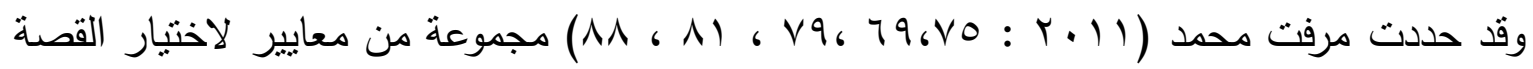
للأطفال ذوي الإعاقة العقلية، وهي ما يأني: - أن تكون الفكرة بسيطة، وواحدة، وواضحة، ومحددة، وتنتاسب مع خصائ، خصائصه، واحتباجاته، ويفهها الطفل ذو الإعاقة العقلية، ويتفاعل معها، ويتقص شخصياتها. - - يجب أن يكون زمن القصة التي تعرض للطفل ذي الإعاقة العقلية في الزمان الحاضر والقريب، وليس الزمان البعيد؛ حتى يستطيع الطفل استيعاب أحداثها. - - مكان أحداث القصة يكون قريب من الطفل، وليس أماكن غريبة عنه. - يجب أن يكون أبطال القصة من الثخصيات المحيطة به. - الأطفال ذوو الإعاقة العقلية يفضلون قصص الحيوانات، وتقليدها، وسماع أصوتها، وقصص البطولة والمغامرة بشرط أن تكون من بيئة الطفل؛ ليقلدها الطفل ويتوحد معها. 


$$
\text { - - يجب عدم وجود الرمزية، والتجريد في أحداث القصة. }
$$

- - يحب الطفل ذو الإعاقة العقلية القصص الاجتماعية والعلاقات الأسرية ، والأحداث

$$
\begin{aligned}
& \text { مألوفة. } \\
& \text { - يجب أن تكون صياغة القصة شيقة وجذابة. } \\
& \text { r- }
\end{aligned}
$$

وللقصة المقدمة للأطفال مجموعة من العناصر يجب الالتزام بها لتحقيق الهدف المنشود من القصة، وسوف يتم عرضها فيما يأتي:

ץ- ع- - - الفكرة القصة:

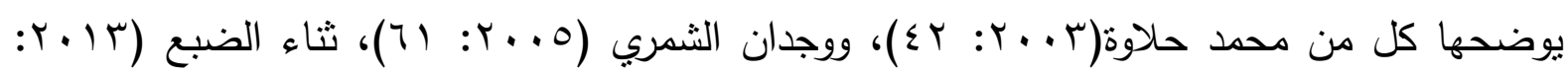

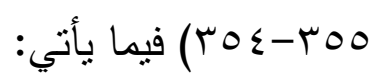

- القصة لها فكرة واضحة، ومحددة.

- أن - أنكون فكرة القصة تتناسب مع خصائص الطفل النمائية.

- - الفكرة مستمدة من بيئة الطفل، وتتسجم معها.

- - أن تتلاءم فكرة القصة مع خبرات الطفل. -

- أن تكون فكرة القصة لها قيمة في حياته؛ ويتحقق ذلك من خلال بناء فكرة القصة في ضوء

احتباجات الطفل لحل مشكلاته التي يعاني منها.

r- r- - - - - حبكة القصة وعقدتها:

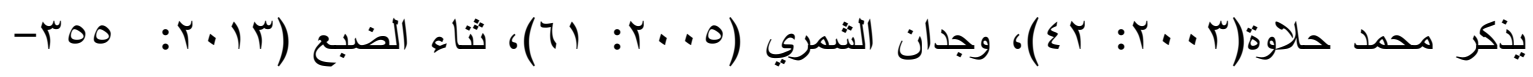

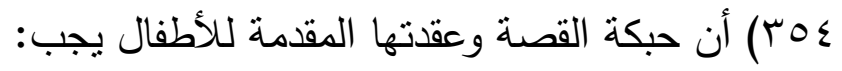

-

-

- - أن يكون حل العقدة المناسب في نهاية القصة، ويقام بشكل منسلسل ومنتابع.

-

وترى الباحثة أن من أهم شروط حبكة القصة المقدمة للأطفال ذوبي الإعاقة العقلية، هي أنه تكون

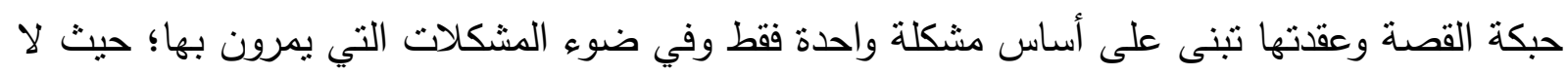

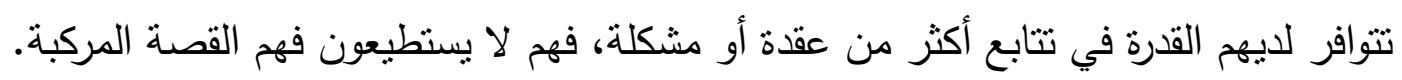


ץ- - - - أحداث القصة:

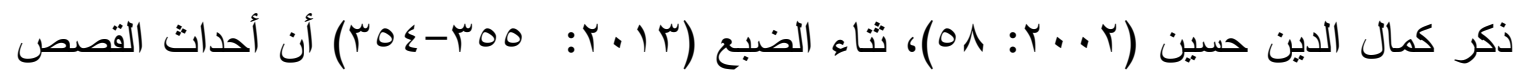

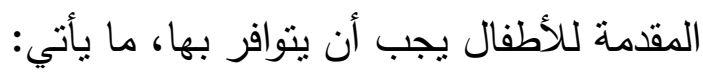
- أن تدور أحداث القصة حول خبرات الطفل الواقعية الحياتية. -

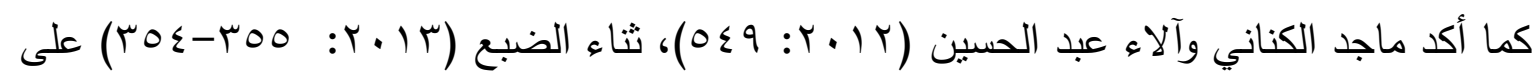
أن تكون الأحداث بها، ما يأتي:

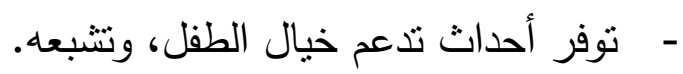
- ق قلة الأحداث داخل القصة.

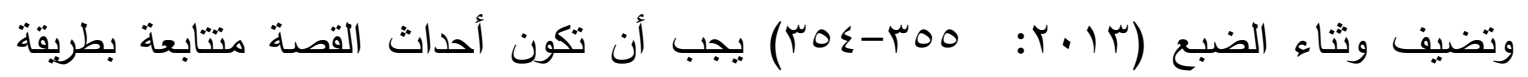
منطقية، ومفهومة، ومترابطة وذات علاقة ببعضها.

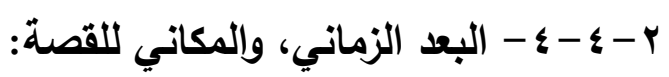

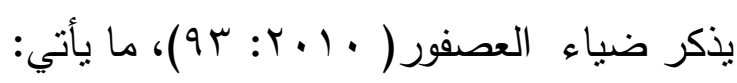
- - أحداث القصة في زمن واحد فقط. - مكان أحداث القصة مرتبط بخبرة الطفل، ولا يوجد مكانين.

وترى الباحثة إلى أن البعد المكاني، والزماني في قصص الأطفال ذوب الإعاقة العقلية يجب أن يتوفر به ما يأني: - n وتري - - أحداث القصة المقدمة للطفل ذي الإعاقة العقلية يجب أن تكون في الزمن الحاضر للطفل، ومكان الذي يعيش فيه الطفل.

- - البعد عن قديم الزمان أو المستقبل، والأماكن البعيدة لصعوبة إدراك الطفل ذي الإعاقة العقلية لذلك.

ץ- צ-ه- - لغة القصة:

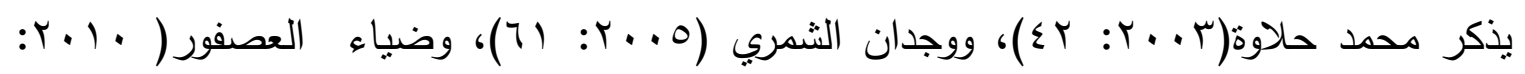

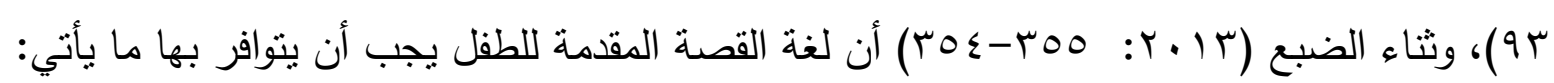
- - لغة سهلة على الطفل وبسيطة.

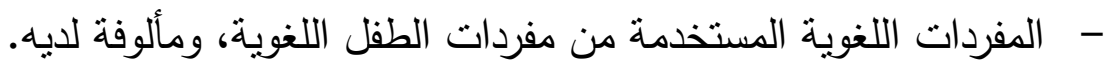
- - عند استخدام مفردات لغوية جديدة، يتم شرحها للطفل من قاموس مفرداته. - لابد من توفير حوار ممتع لأحداث القصة. 


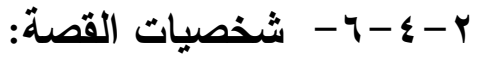

ويقصد بهم كمال مرسي (997 (1: rعץ) الذين يقومون بالأعمال، والأحداث في القصة ، ويجب

- - تشكل شخصيات القصة المقدة للأطفال السلوك المقبول الصحيح، ولا تقدم السلوك الخطأ. يتجنبها، وينفر منها الطفل.

- أن تخلو القصة من شخصيات معقدة، وأفكار عنيفة.

- - تكون شخصيات القصة واضحة ومحددة، ولا يزيد عددها عن مستوى قدرة الطفل لمتابعتها. -

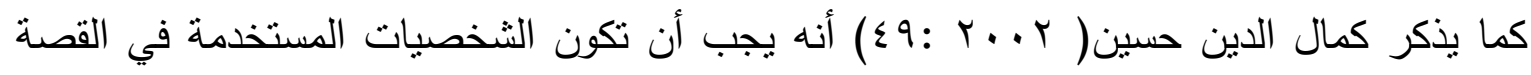

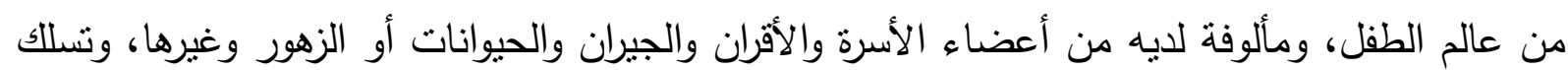

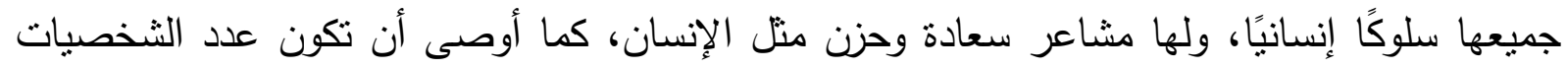

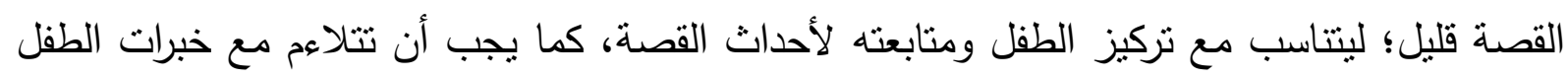

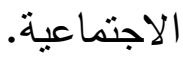

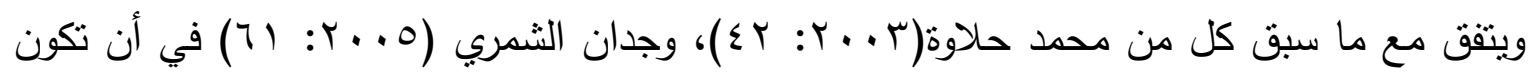
الثخصيات القصة قريبة، ومألوفة من عالم الطفل، كما يضيفان توفيرها لثخصيات تثير خياله، ويذكر

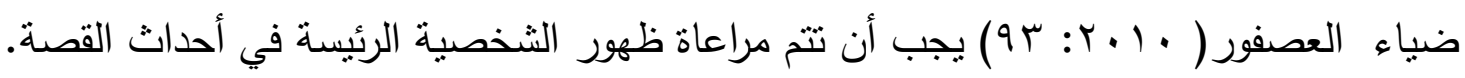

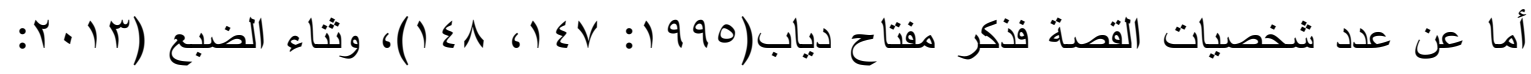

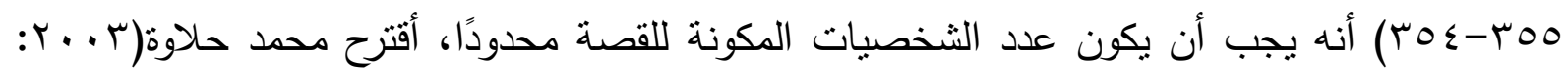

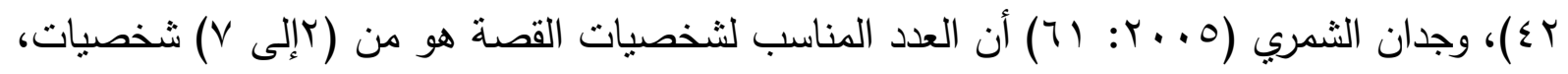

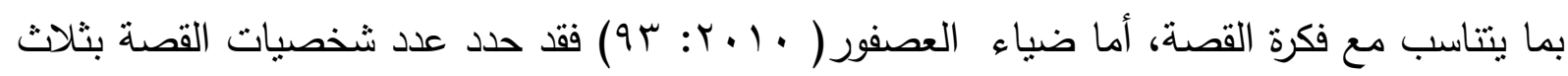
شخصيات.

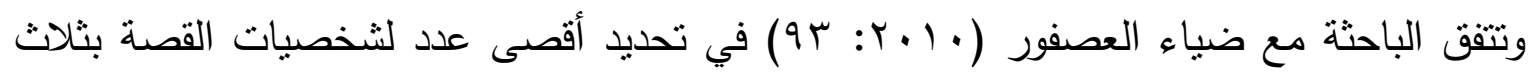
شخصيات فقط، وتضيف أن أطفال ذوي الإعاقة العقلية، وفي مرحلة الروضة لاهي لايتاسب معهم عدد كبير

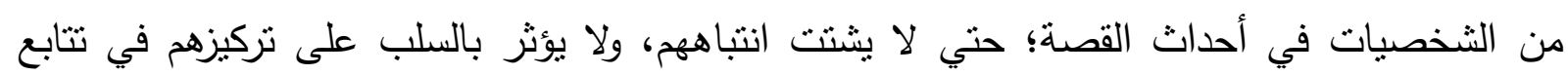
أحداث القصة، وحتي يسهل عليهم منابعة القصة، وسهولة سردها وتذكرها مرة أخرى، وتمثيلها. 
r - - - - الشكل المادي للقصة:

وسوف يتم تناول الثكل المادي للقصة، من حيث ما يأتي : 

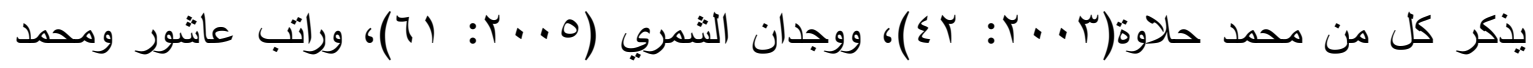

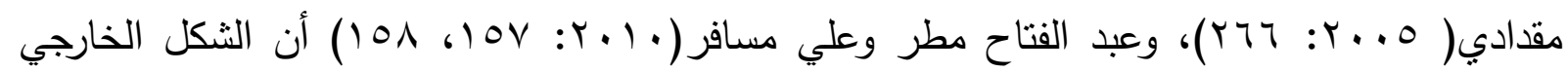

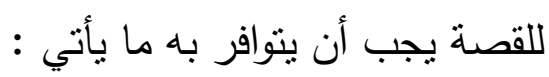
- متانة غلاف القصة وجودنه. - - - أن يتضمن غلاف القصة عنوانها. - - أن يكون شكل القصة عبارة عن بطاقات، أو دفتر قلاب. - حجم القصة مناسب ليسنطيع الطفل حمله. - - أن يكون الغلاف والأوراق الداخلية مصنوعة من الأوراق المتينة. r-

إن الصور والرسوم ليست وليدة هذا العصر، بل هي موجودة منذ زمن قديم، وفي جميع الحضارات والثقافات، ففي الثقافة الصينية الصور والرسوم نساوي ألف كلمة، ويذكر أن الناقد الفرنسي (رولان بارت)

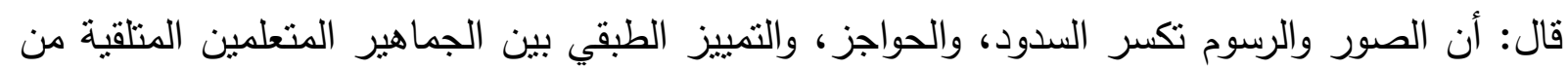

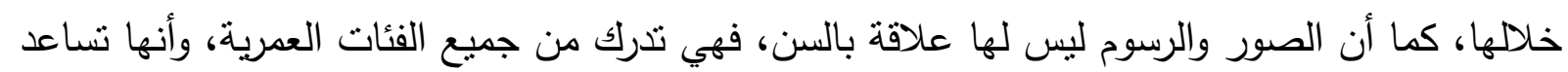

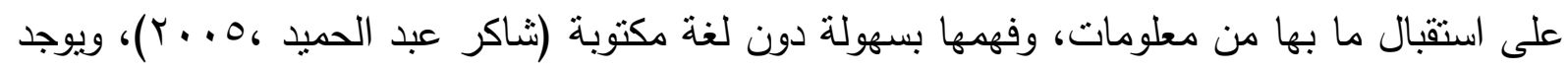

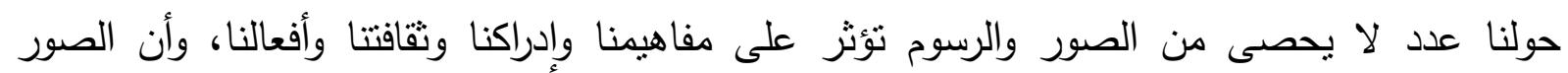

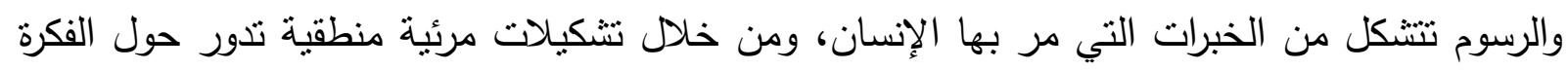

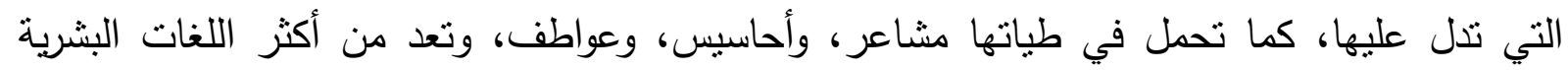

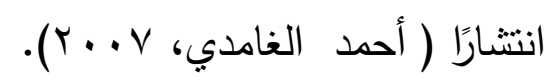

من أهم حواس الإنسان حاسة البصر ، وهي أكثر الحواس المستخدمة في تلقي المعلومة، وتعد الصور

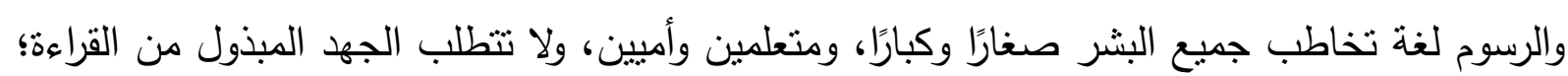

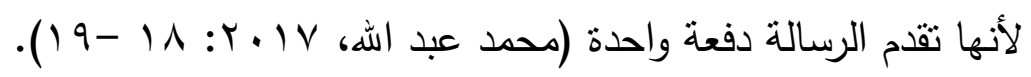

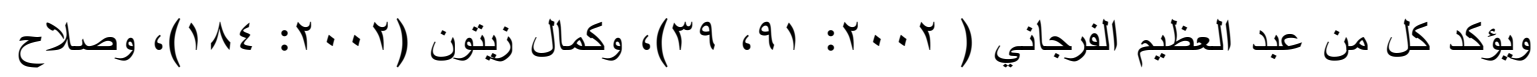

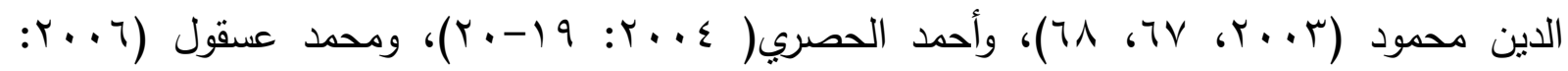

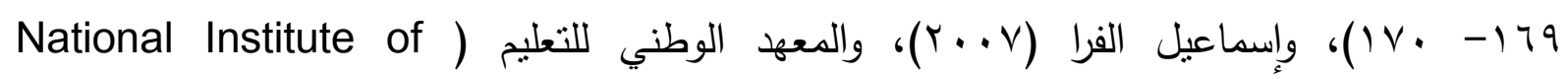

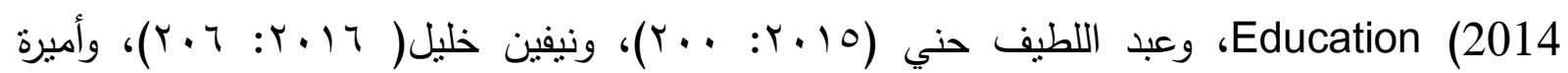

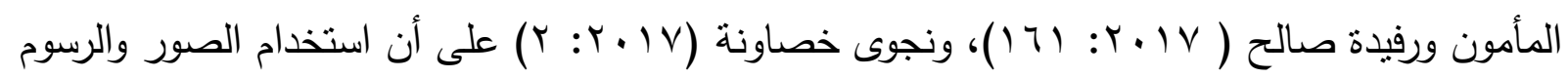


له تأثير قوبي وفعال في تتمية الجانب المعرفي للمتعلم، يتعدى الكلام المكتوب بطريقة جذابة وفنبة وسهلة

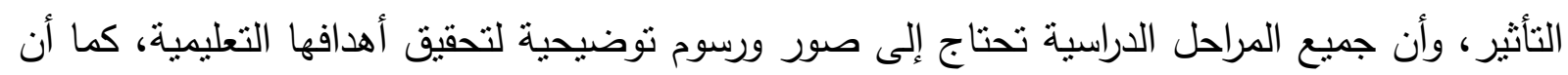

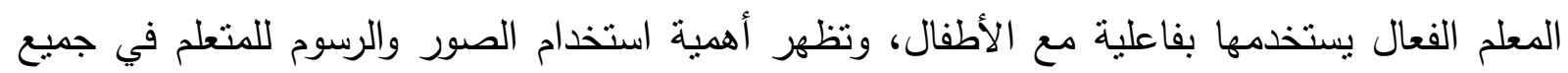

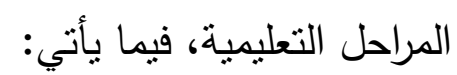
- - إثارة الدافعية للمتعلم، وتحفيزه لجميع المعلومات، والمعارف المقدمة من خلالها. - - تقديم المعلومات بطريقة منظمة، وسهلة، ومفسرة. - - تقدم المعلومة بشكل بصري يسهل تذكره.

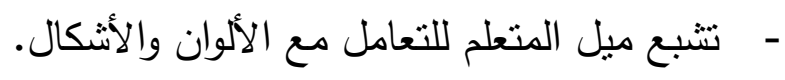

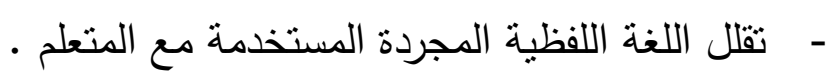
- - - غير مكلفة، وسهلة الإنتاج. - - تكسب المتعلم المعلومة في أقل وقت. - مساعدة المتعلم على التصور، والتخيل. - الاحتفاظ بالمعلومة المكتسبة من خلال الصور والرسوم لأطول فترة مدكنة، بقاء أثر التعلم للمتعلم.

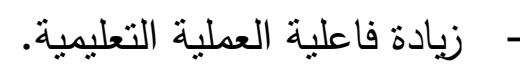
- ت تسيق المقرر بطريقة تجذب الانتباه لجميع المتعلمين في جميع المراحل الدراسية. - - تساعد المتعلم على سهولة عمل المقارنة بين الأشكال والأحجام والمسافات. - لها فائدة تعويضية للأطفال ذوي الاحتباجات الخاصة - فيما عدا المكفوفين - الملتحقين بمراحل التعليم المختلفة. - - ت تحسين التواصل بين المعلم، والمتعلم في الموقف التعليمي. - - تدريب المتعلم على مهارة قراءة الصور والرسوم المقدمة إليه. - - ت تساعد على تحقيق أهداف المادة التعليمية. - - تتمي مهارات المتعلم العقلية كالإدراك، وسرعة الاستيعاب، والفهم، وتكوين المفاهيم وتتميتها، كما

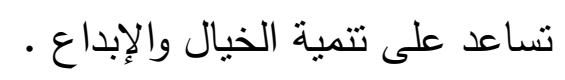

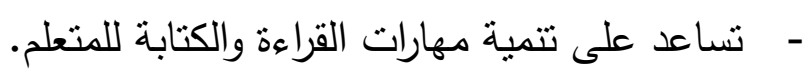
- توحي للمتعلم بالحركة، حتى لو كانت صورًا ورسومًا ثابتة.

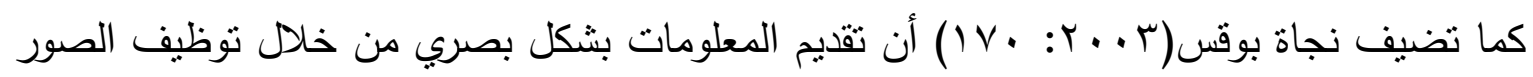
والرسوم يعمل على تتمية الثقافة البصرية لاى المتعلم. ץ-ه - أهمية استخدام الصور والرسوم في قصص الأطفال ذوي الإعاقة العقلية البسيطة: 
بالإضافة إلى العرض السابق لأهمية الصور والرسوم للمتعلم في جميع المراحل التعليمية، يؤكد

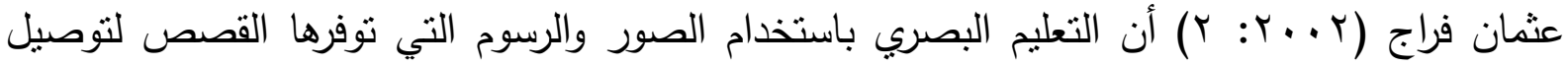

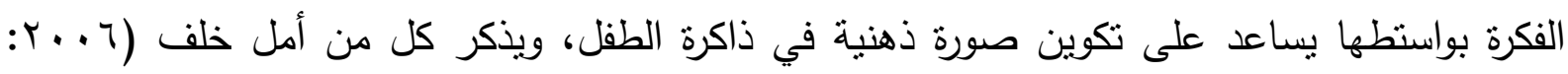

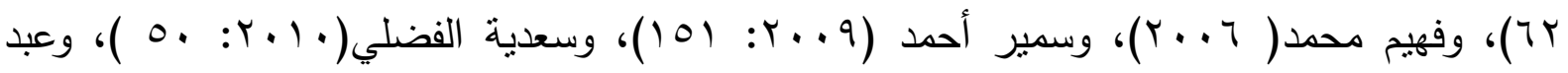

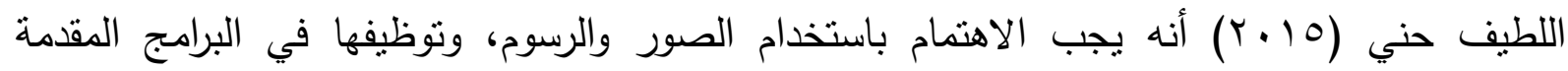

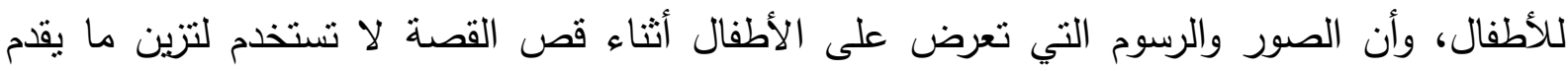

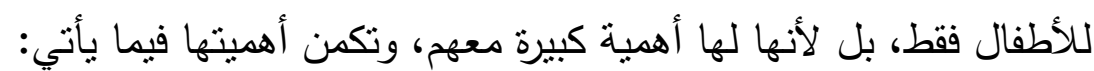

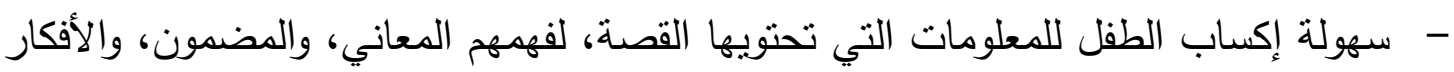

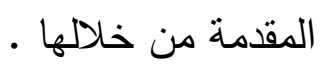

- - لها ضرورة تربوية ونفسية؛ لإقبال الأطفال على ما يقدم لهم من خلالها في محتوى تعليمي. - - المساعدة على إدراك أحداث القصة. - ت تمية التعبير ، والتذوق الفني من خلال ألوان الصور والرات الرسوم. - الرسوم في القصص المقدمة للأطفال تجذب انتباهم. - تتمية اللغة من خلال عرض الصورة أو الرسم مع الشرح الصوتي المصاحب، ويساعد ذلك لكأل على الربط بين الصور والرسوم المقدمة، والمكون اللفظي المعروض للقصة؛ مما ينمي المهارات اللغوية، كاللغة التعبيرية المستخدمة لوصفها.

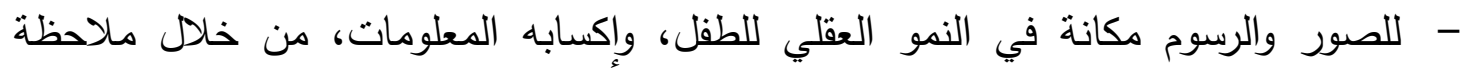

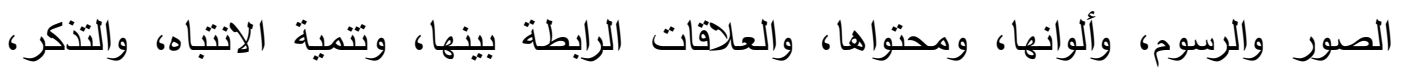

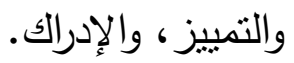
- للصور والرسوم دور كبير في تكوين الصورة الذهنية لأحداث القصة.

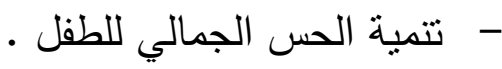
- سهولة الاتصال بين المعلمة والأطفال؛ لسهولة فهم الأطفال لأحداث القصة. - ت ت تمية قدرة الطفل على تخيل الأحداث، وتصورها. - تحويل معلومات المقدمة من خلال القصة إلى معلومات بصرية مكانية. - تساعد المعلمة على توفير جهدها لتوصيل المعلومة. - - عرض الصور والرسوم على الأطفال براعي الفروق الفردية فيما بينهم.

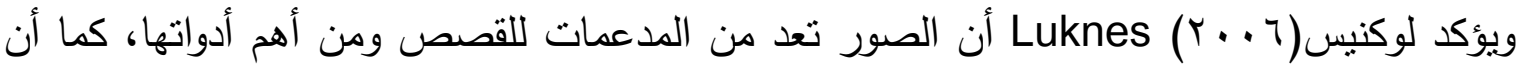

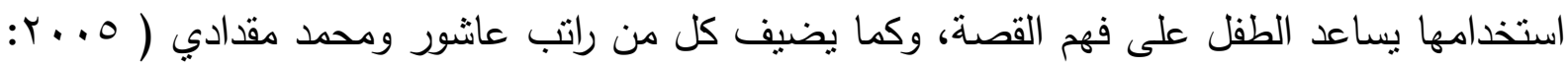




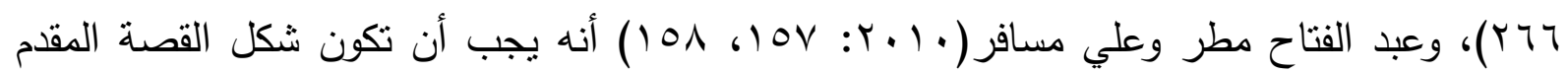

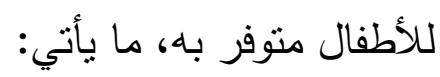

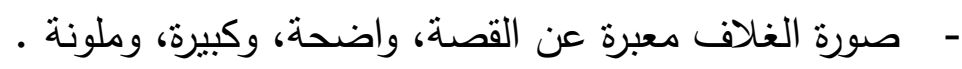

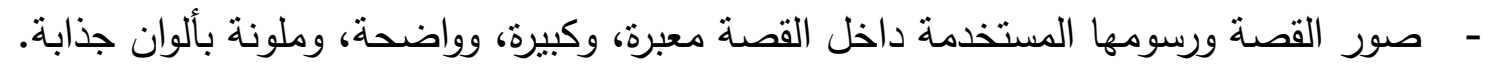
- - م- ألوان القصة زاهية، وواقعية. ץ-ه- - قراءة الصور والرسوم :

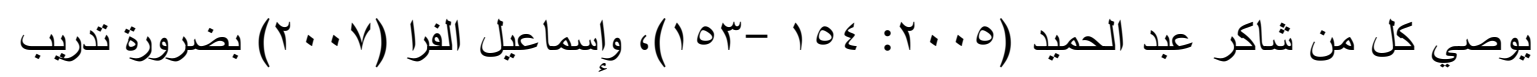

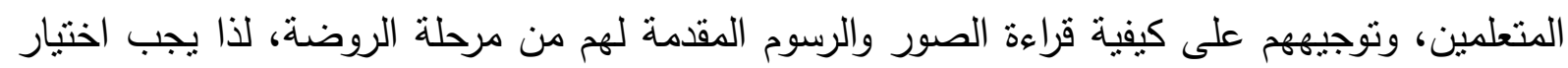

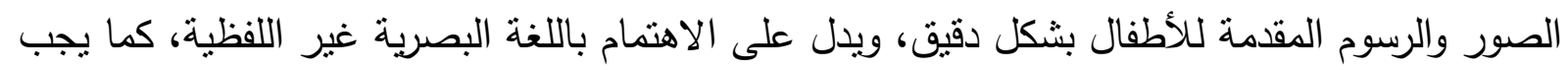
تدريب الأطفال على قراءة الصور والرسوم، وكيفية التعامل معها، في جميع المراحل التعليمية من مرحلة التهلة الروضة إلى مراحل التعليم العالي بالجامعة.

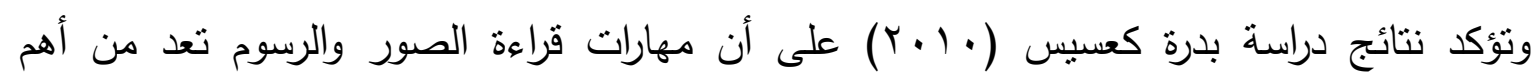
المهارات التي يجب أن تكسب وتتمي الطفل منذ مرحلة الروضة، وتعد الصور والرسوم لغة غير لفظية تعمل على التتشيط البصري العقلي لطفل الروضة.

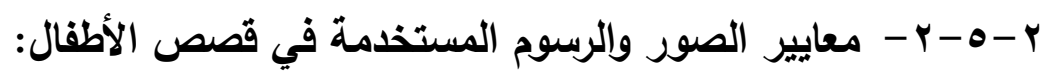

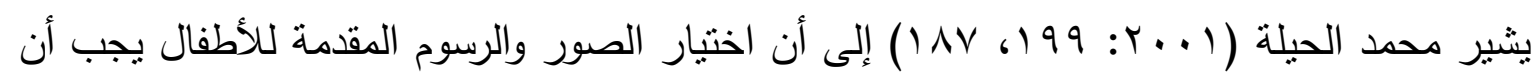
يتوافر بها أسس ومعايير، وهي ما يأني: - - أن تجذب انتباه الأطفال.

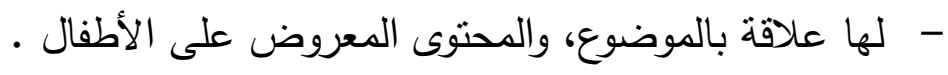
- تثميز بسهولة التمييز لمحتواها. - لها حجم مناسب بالنسبة للطفل ليسهل حملها، وييسر إدراكها بنظره. - - مناسبتها لخصائص الطفل، وعمره، وخبراته. - - ت تميز بتتظيم معلوماتها.

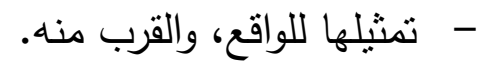
- لها قيمتها التربوية في استخدامها مع الطفل.

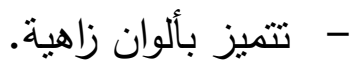


أن الرسوم تبسط الأفكار والحقائق بطريقة يسهل على المتعلم إدراكها من خلال إظهار العناصر الرئيسة المهمة، واستبعاد العناصر غير مهمة لتوضيح الفكرة التي تعبر عنها(علي عبد المنعم ، .... ب:

أن الرسوم و الصور أحد وسائل الاتصال المهمة؛ لأنها تختصر مضمون الرسالة في تكوينات خطية

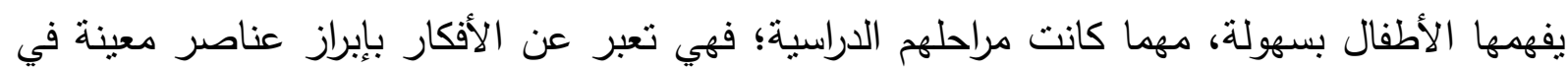
المواقف دون عناصر أخرى، وهي لا تهدف إلى إظهار التفاصيل كما تفعل الوسائل البصرية الأخرى

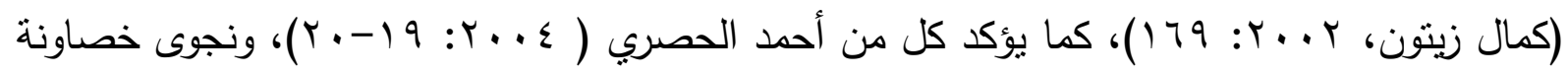

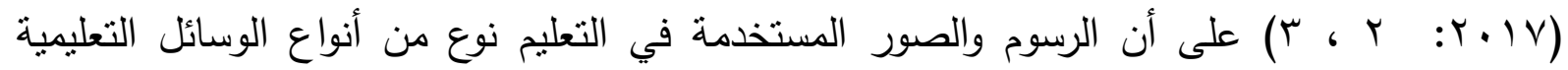

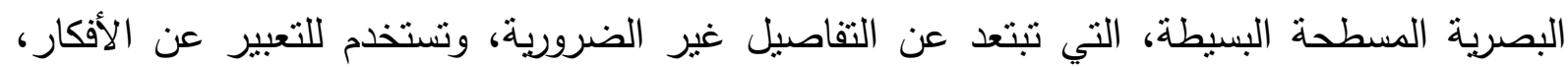

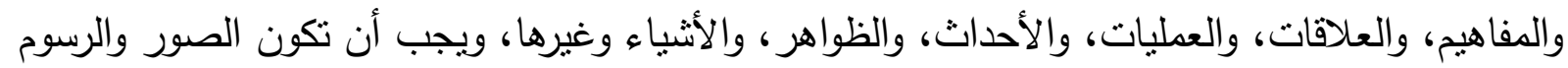
مكونًا أساسيًا في جميع المقررات المقدمة للمتعلم، وبالرغم من خلوها من الحركة والصوت فإنها لها فوائد متعددة في تعليم الطفل وتحقيق الأهداف التعليمية المنشودة.

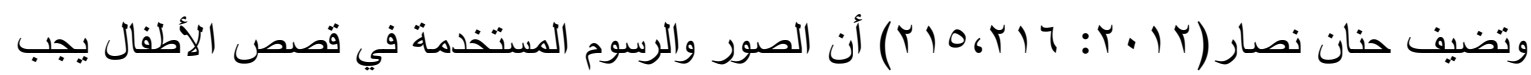

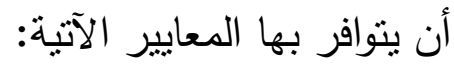
- أن تنتخدم أكثر من لون، ولا نستخدم درجات اللون الواحد. - - التتوع في لقطات الرسوم والصور المستخدمة لعدم شعور الطفل بالملل. - - التقليل من التفاصيل وبخاصة التفاصيل التي في خلفية الصور والرسوم.

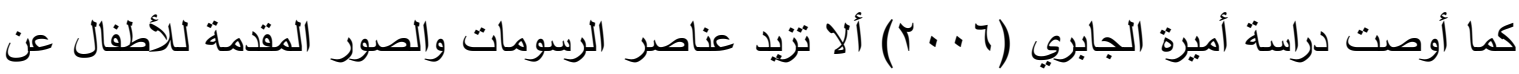

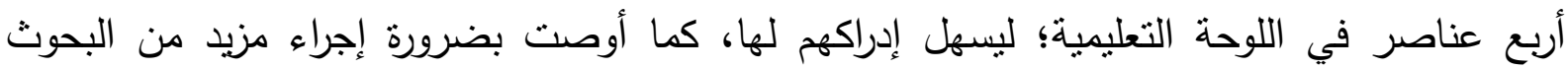

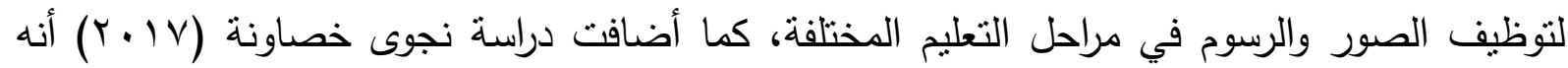

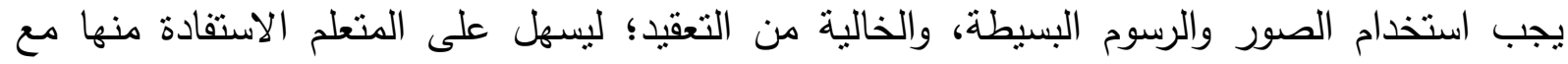
مراعاة صحة المعلومات بها، والدقة العلمية في تقديم المعلومات من خلالها، وأوصت دراسة أميرة

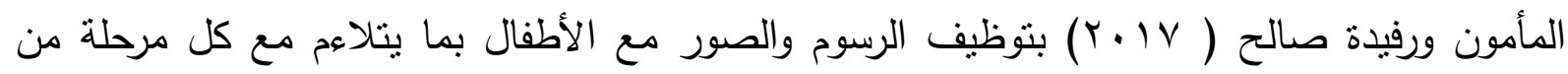

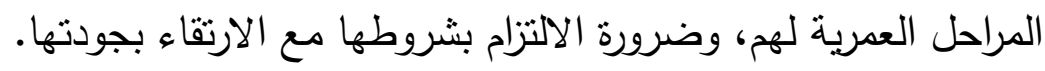
وهناك العديد من الدراسات والأبحاث السابقة التي اهتمت بالقصة، وأثنتت فاعليتها مع الأطفال في

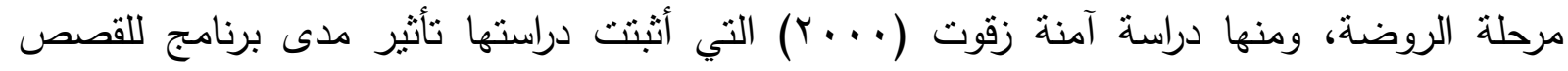

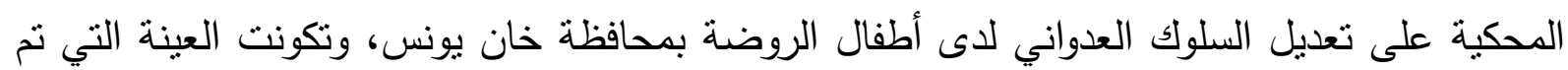
تطبيق عليها برنامج الدراسة من (rT) طفل وطفلة، قسموا على مجموعنين تجريبية وضابطة كل لكل 
مجموعة مكونة من (7 (1) طفلا، وكل مجموعة مقسمة إلى (^) ذكور ، و(^) إناث بالتساوي، ويتراوح

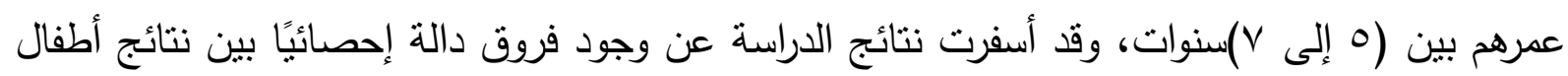

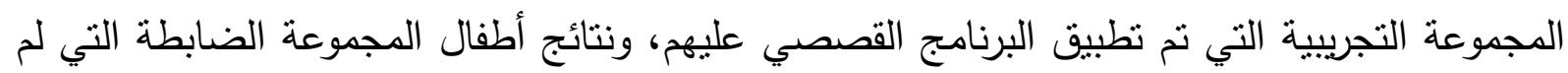
تتلق البرنامج، لصالح أطفال الهجمعة التجريبية، وقد ظهر ذلك من خلال تعديل سلوكهم العدواني، كما ظهر التحسن الواضح لدى أطفال المجموعة التجريبية في سلوكهم.

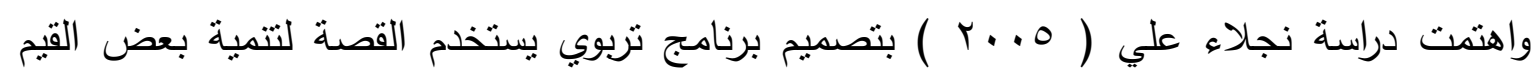

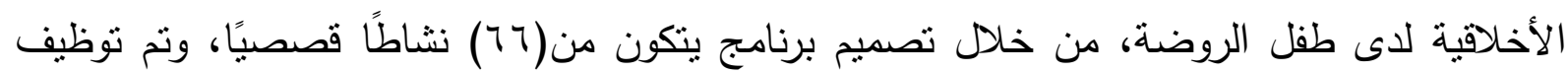

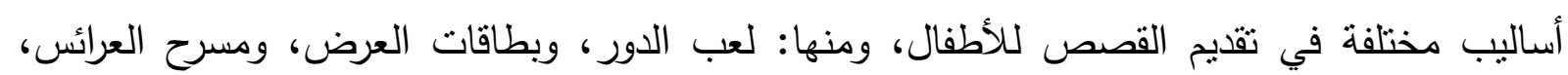

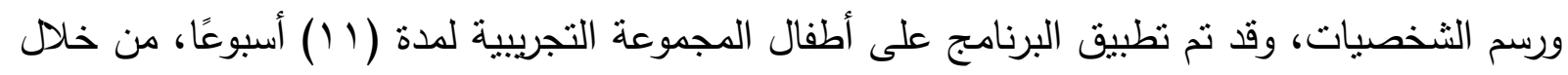

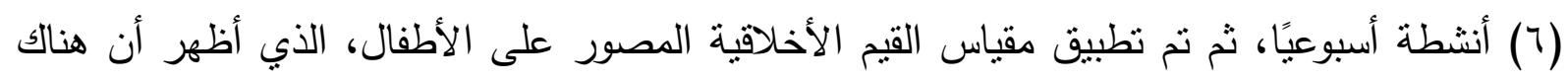

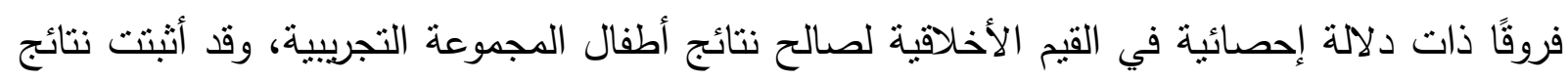

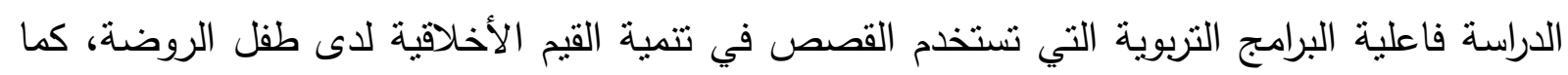

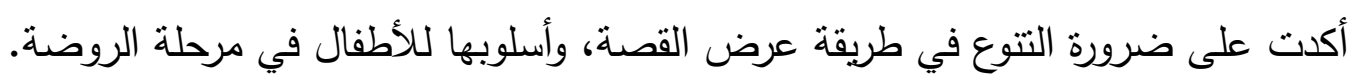

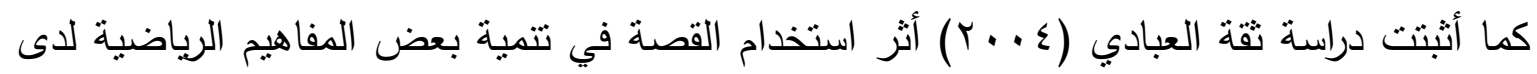

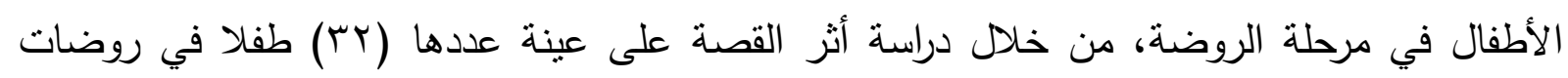

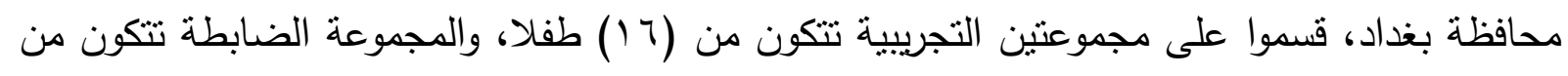

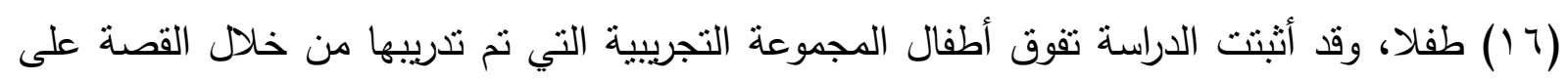

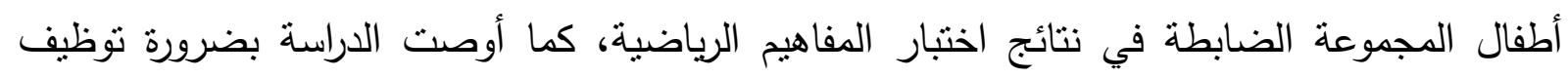
القصة مع الأطفال في مرحلة الروضة.

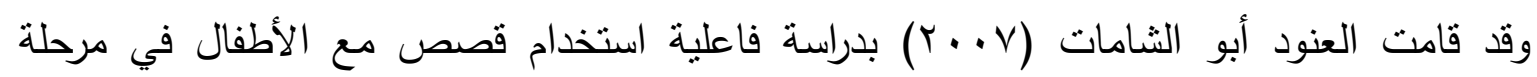

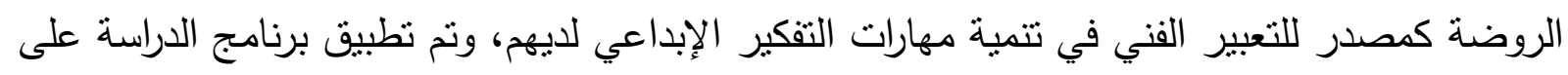

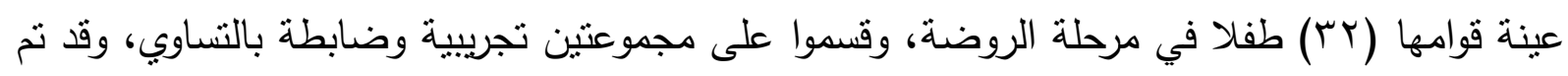

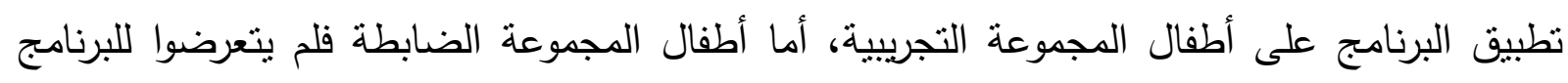

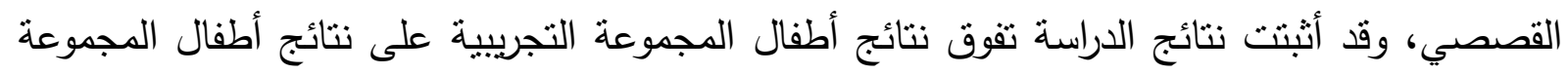

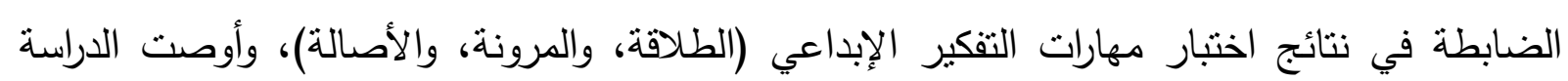
بتوفير قصص في مرحلة الروضة للأطفال لتتمية التفكير الإبداعي لديهم.

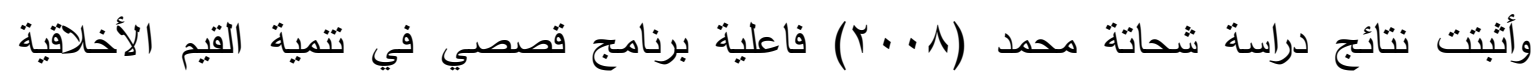

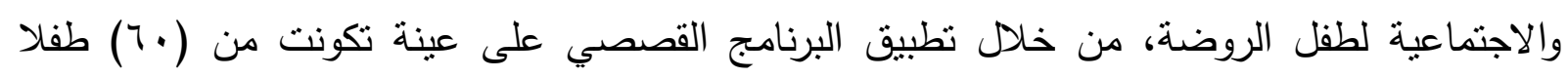

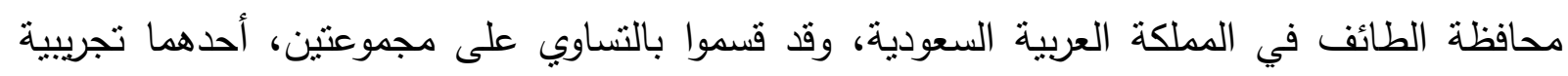


والأخرى ضابطة، وأثتبت الدراسة وجود فروق ذات دلالة إحصائية لصالح نتائج أطفال المجموعة

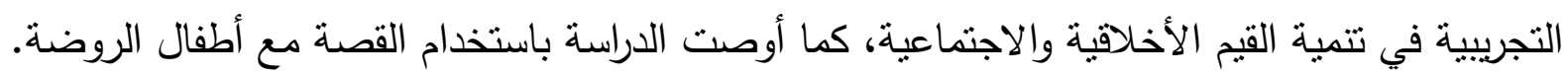

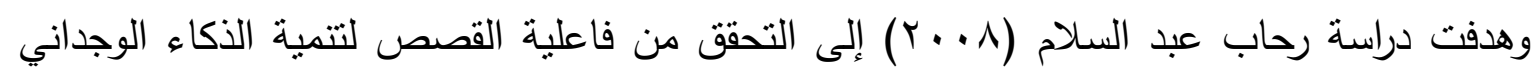

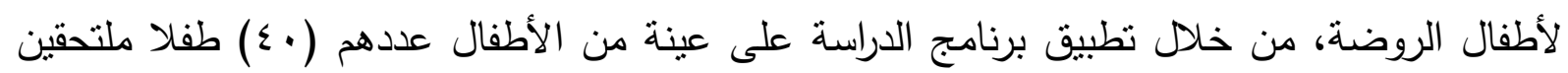

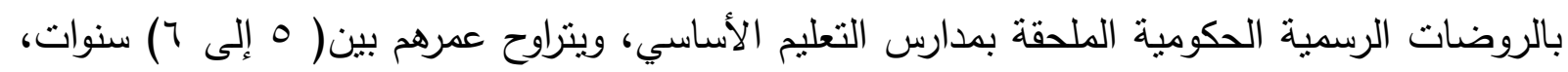

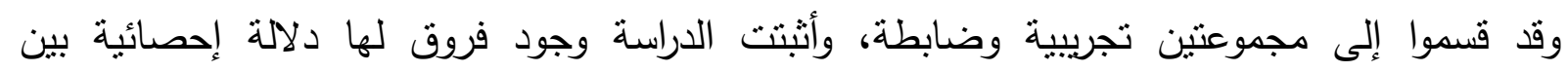

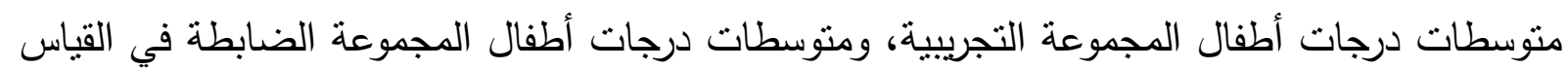
البعدي لمقياس الذكاء الوجداني لصالح نتائج أطفال الدجموعة التجريبية.

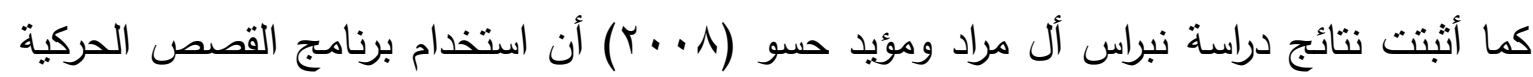

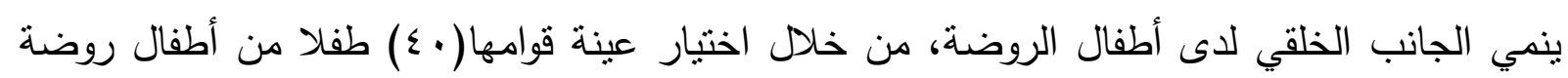

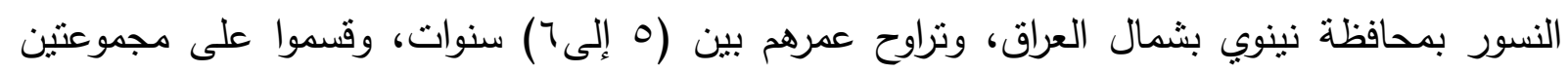

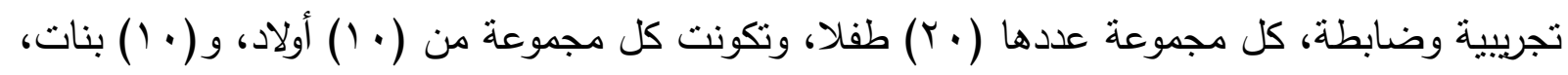

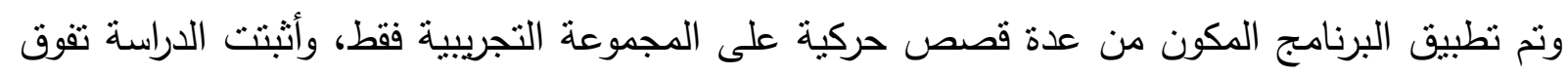
نتائج أطفال المجموعة التجريبية في القياس البعدي لمقياس الجانب الخلقي بالمقارنة بنتائج أطفال المجموعة الضابطة.

وتؤكد دراسة بوسف كمال (9 . ب) فاعلية القصص المصورة المقدمة لأطفال الروضة في تتمية

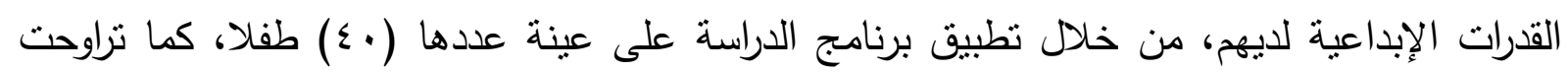

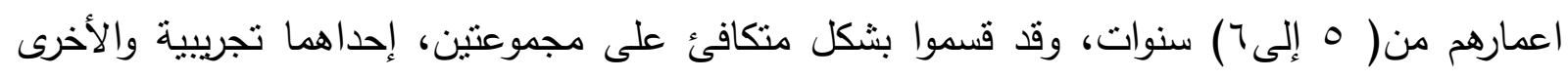

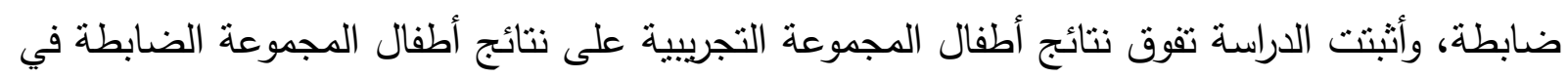
التطبيق البعدي لاختبار القدرات الإبداعية.

كما أظهرت نتائج دراسة ماجد الكناني وآلاء عبد الحسين (Y ( ب) فاعلية القصة الكارتونية كمصدر للتعبير الفني لطفل الروضة، ونم ذلك بتطبيق البرنامج القصصي على عينة قوامها(· ب) طفلا، تراوح

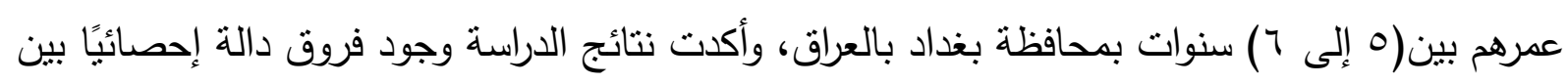
نتيجة تطبيق اختبار التعبير الفني قبل نطبيق البرامج القصص وبعده، لصالح نتيجة التطبيق البعدي،

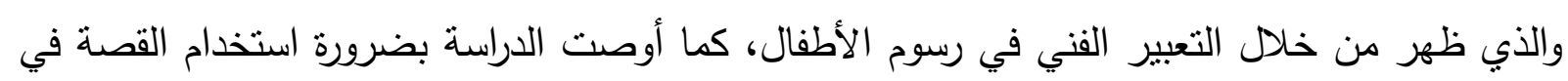
مرحلة الروضة لتتمية مهاراتهم، وإكسابهم العديد من السلوكيات.

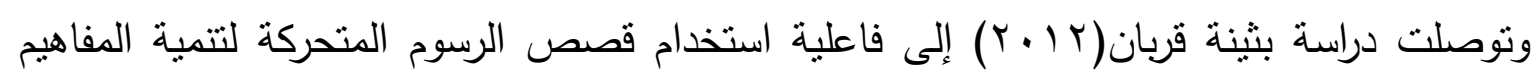
العلمية وتتمية القيم الاجتماعية لطفل الروضة بالمملكة العربية السعودية، وذلك من خلال تطبيق البرنامج 
على عينة قوامها (.0 ) طفلا، وأثتبت الدراسة أن استخدام القصص مع أطفال الروضة ينمي العديد من

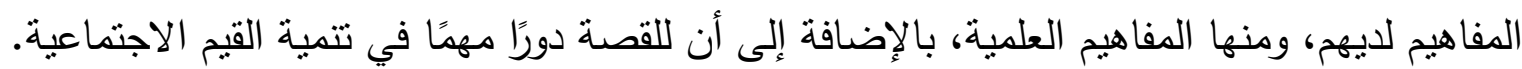
وأثتتت دراسة ريمه الحربات (ع (ب) أن القصة لها دور كبير في إكساب أطفال مرحلة الروضة الخبرات العملية، وظهر ذلك من خلال تقديم برنامج قصصي لعينة من الأطفال في مرحلة الروضة إبها

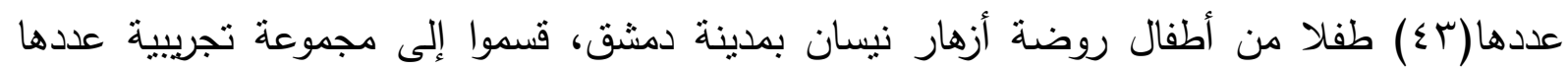

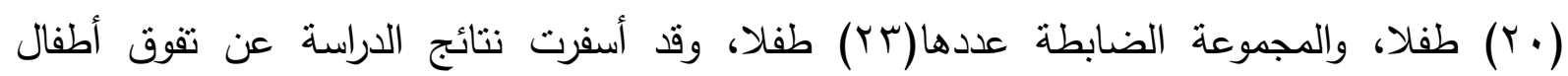

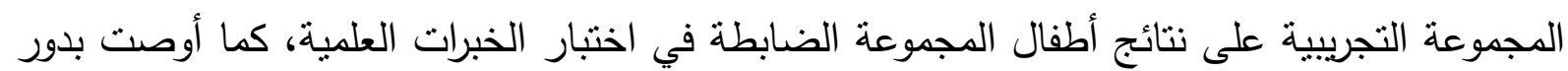
القصة في إكساب أطفال الروضة خبرات علمية مهمة له في بيئته وحياته، وهي : وطني سوريا، وخبرة النباتات، والكون والطبيعة، وقد أوصت الدراسة باستخدام القصص مع الأطفال في مرحلة الروضة. وأكدت نتائج دراسة هديل العرينان(10 ب ب) فاعلية القصص الإلكترونية في تتمية المهارات اللغوية

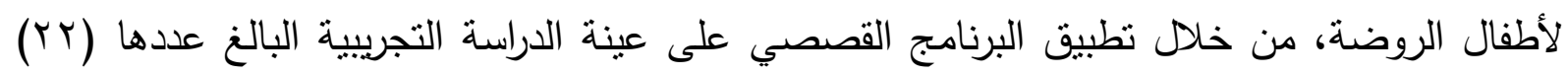

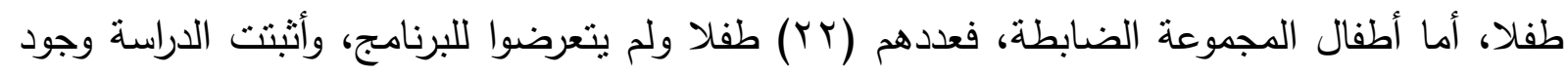

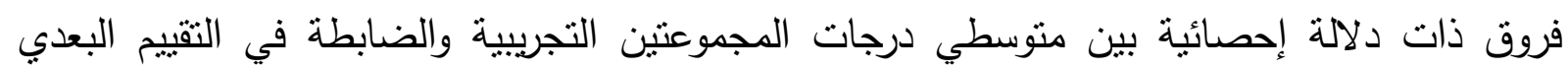

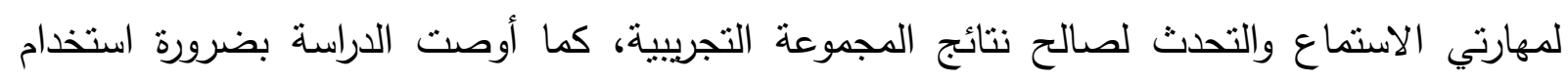

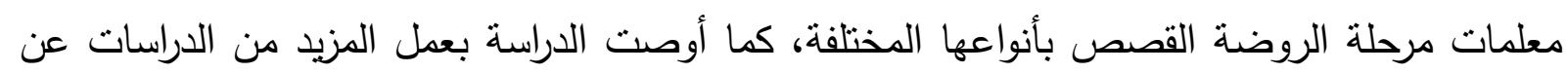
توظيف القصص مع أطفال مرحلة الروضة. وأثتبت دراسة شيماء الراوي(10 ب ب) أثر برنامج ألعاب استكثافية مقدم من خلال القصص الحركية

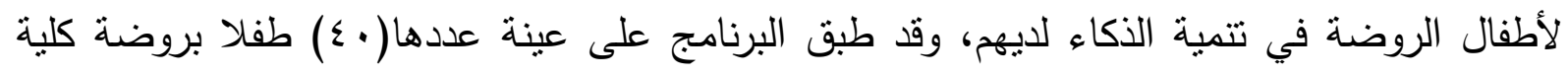

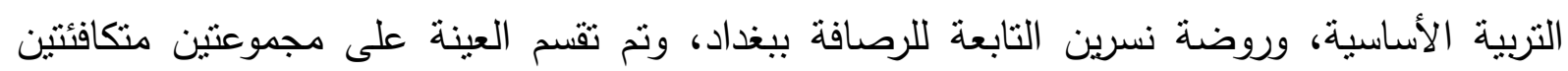

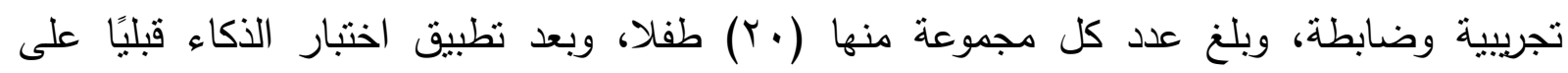

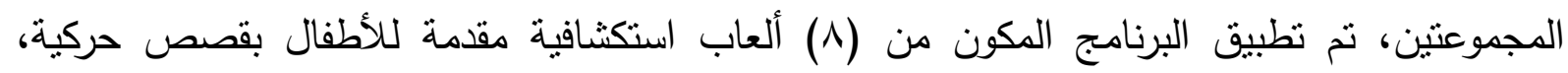

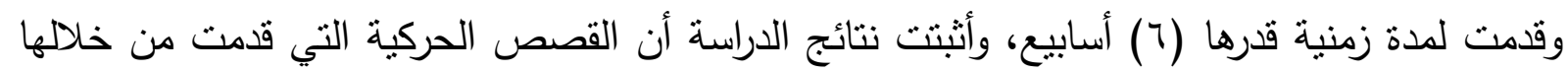

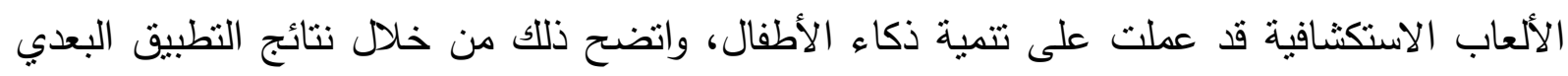
لاختبار الذكاء على المجموعنين الضابطة والتجريبية، وجاءت النتائج لصالح أطفال المجموعة التجريبية، وقد أوصت الدراسة باستخدام القصص بأنواعها المختلفة مع أطفال الروضة.

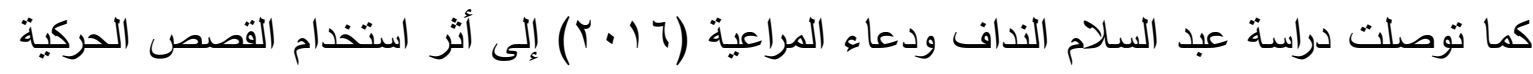

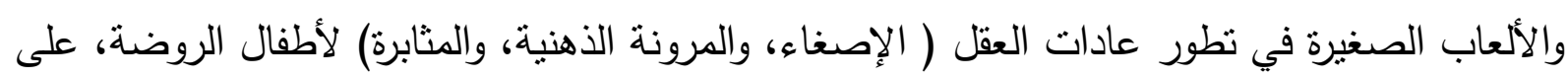

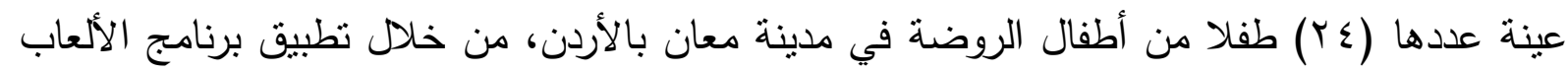

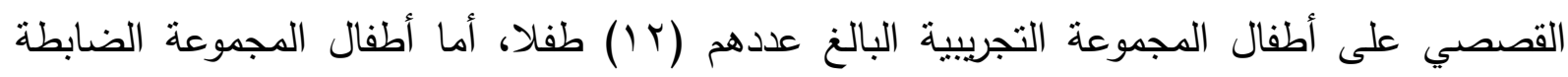


البالغ عددهم (Y ( ) طفلا فلم يتعرضوا للبرنامج، وأظهرت النتائج وجود فروق ذات دلالة إحصائية لصالح القياس البعدي لأطفال المجموعة التجريبية في عادات العقل، وقد أوصت الدراسة بضرورة استغلال ميل

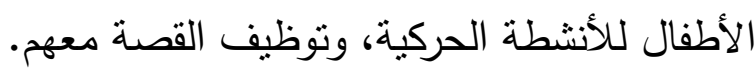

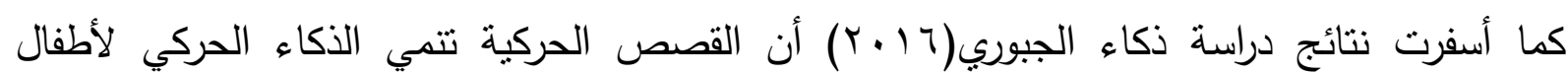
الروضة، وقد ظهر ذلك من خلال تطبيق برنامج الدراسة على مجموعة من أطفال عددهم (بَّ) طفلا،

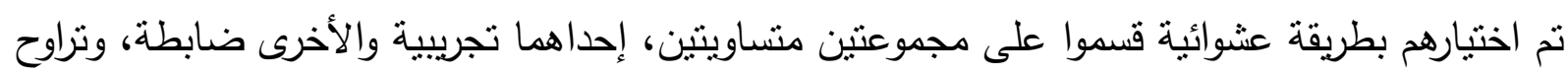

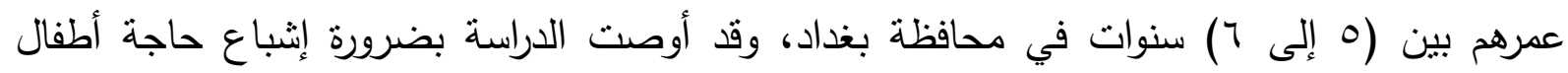
الروضة في الحركة والنشاط بطرق غير تقليدية، من خلا تطبيق القصص الحركية.

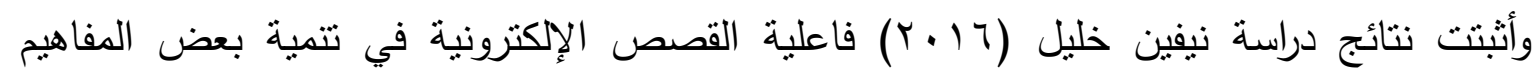
العلمية لأطفال الروضة، من خلال تطبيق برنامج الدراسة، وهو وحدة مقترحة لتتمية المفاهيم العلمية،

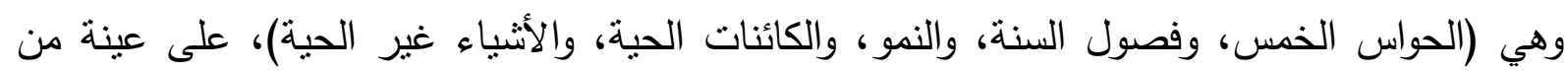

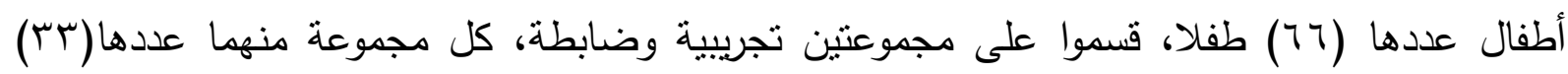
طفلا، ملتحقين بالمستوى الثاني روضة، نم اختبارهم من المدارس الرسمية التابعة لوزارة التربية والتعليم،

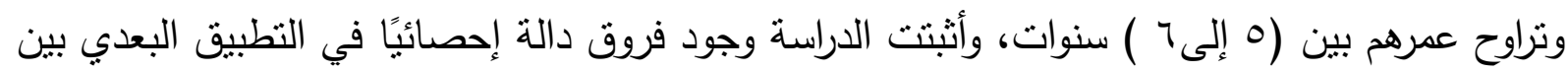

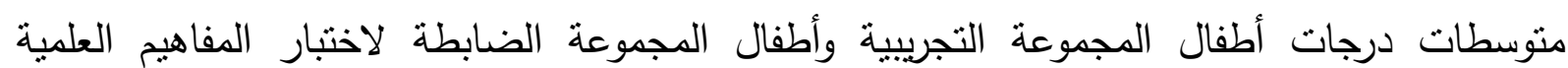
المصور لصالح المجموعة التجريبية.

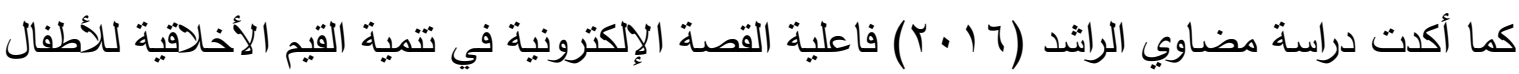

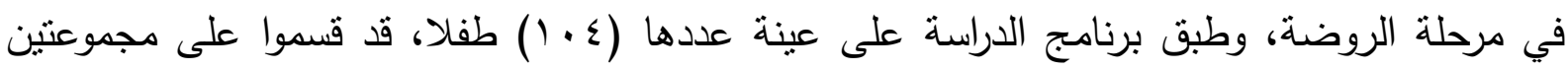

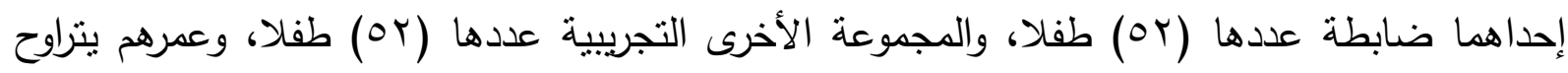

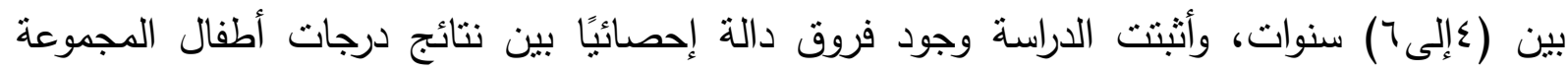
التجريبية وأطفال المجموعة الضابطة في قياس القيم الأخلاقية لصالح التطبيق البعدي للمجموعة التجريبية، كما أكدت الدراسة على ضرورة استخدام القصص بأنواعها مع الأطفال. كما تتاولت العديد من الدراسات دراسة فاعلية القصة مع الأطفال العاديين في مرحلة الروضة،

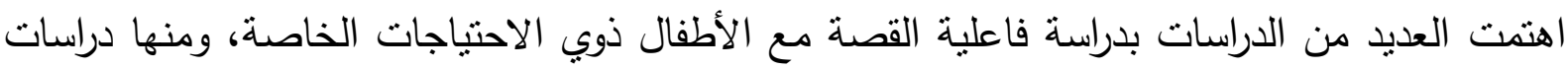

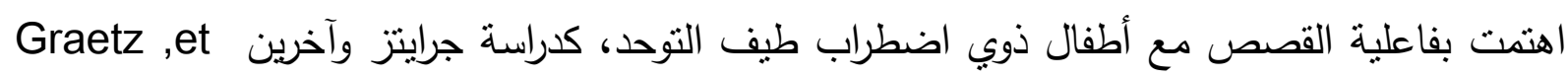
al,(2003)

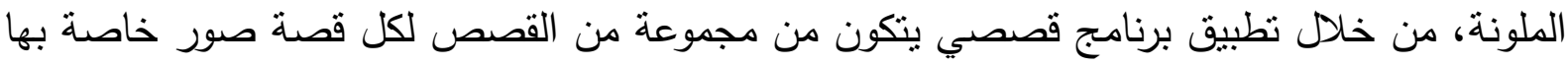

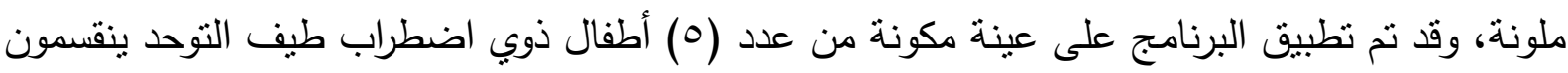

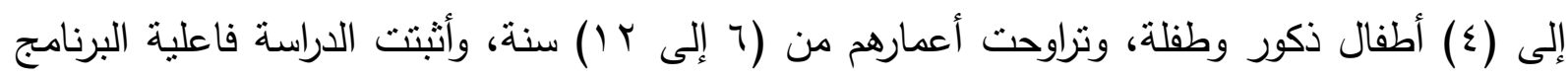


القصصي المقدم من خلال قصص مصورة وملونة في خفض السلوكيات الصادرة غير المرغوبة فيها من الأطفال ذوي اضطراب طيف التوحد، ومنها وضع اليد أو الأشياء الغريبة في الفم.

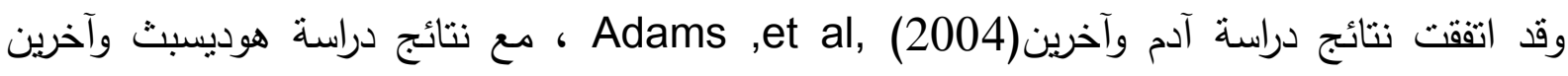
Hudspeth ,et,al(2009) أن القصص المصورة المستخدمة مع الأطفال ذوب اضطراب طيف التوحد تخفض السلوكيات غير السوية التي تصدر منهم، منل: الصراخ، والبكاء، والسقوط على الأرض، والضرب، بالتالي فالقصص تساعد على إكسابهم التفاعل الاجتماعي المقبول بينهم وبين من حولهم، فضلًا عن أن القصص تكسب هؤلاء الأطفال القدرة على تكوين علاقات اجتماعية مع الآخرين. كما أكد بدر Bader(2006 في دراسة له أن القصص تكسب الأطفال ذوي اضطراب طيف التوحد

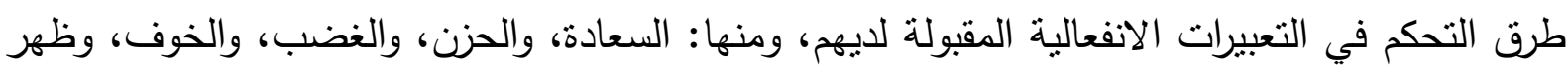

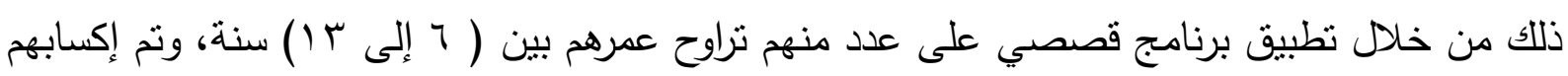

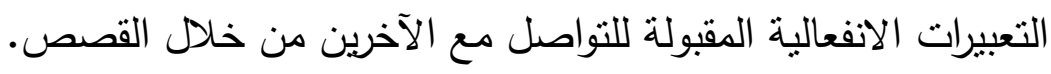

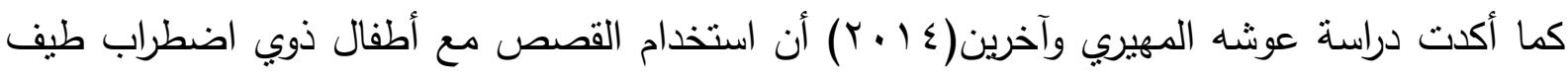

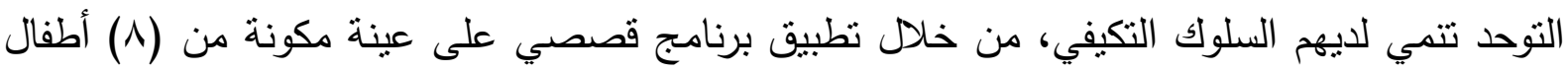

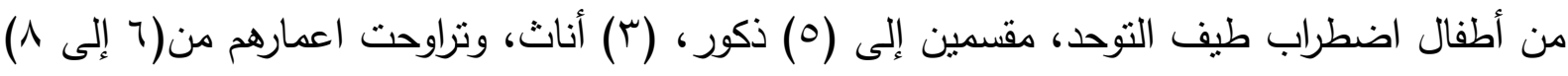

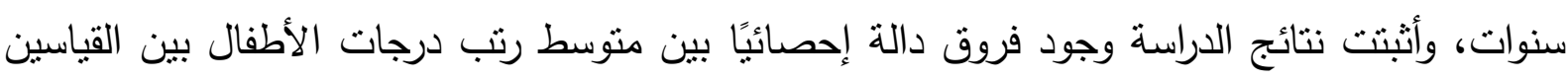

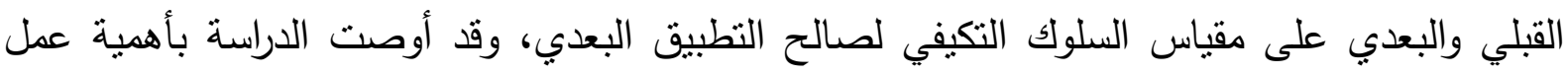

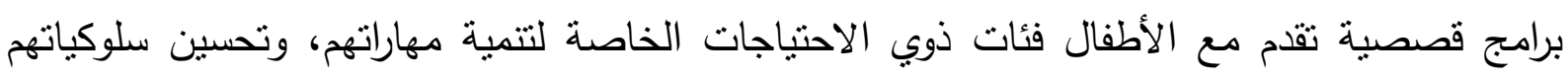
التكيفية.

وكما أثثتت القصة فاعليتها مع الأطفال ذوي صعوبات التعلم، وظهر ذللك من خلال نتائج دراسة عبد التها الله آل تميم ( و ع أهـ) التي تحققت من فاعلية استخدام القصة المسجلة على الأقراص المدمجة (CD)

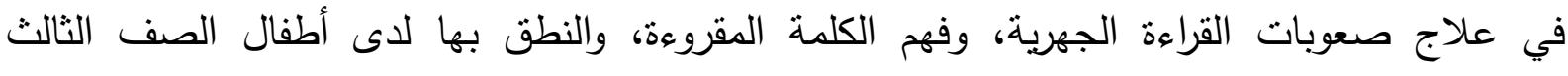
الابتدائي، وقد بلغت عينة الدراسة (ع T) طفلا، قسموا بالتساوي على مجموعتن إحداهما تجريبية عددها

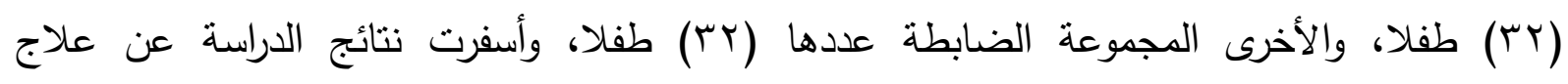
صعوبات القراءة الجهرية للأطفال ذوبي صعوبات القراءة، ومنها: الحذف، والإضافة، والابدال، والتكرار

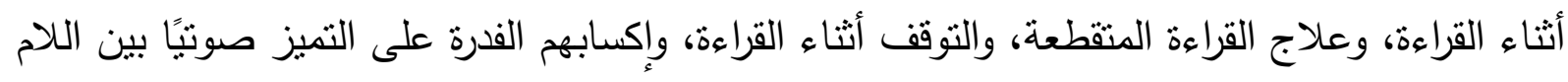

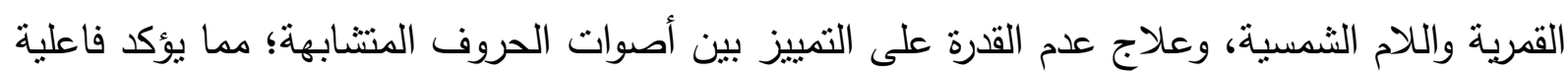

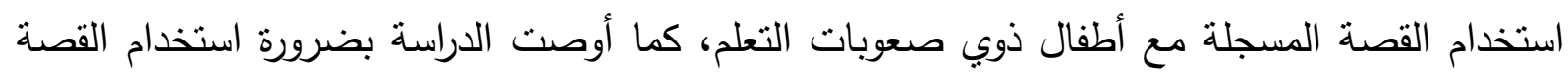
مع جميع الأطفال ذوي الاحتياجات الخاصة. 
كما تم الحصول على عدد من الدراسات التي اهتمت بدراسة فاعلية القصة مع الأطفال ذوي الإعاقة

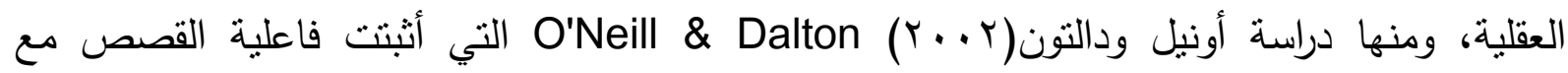

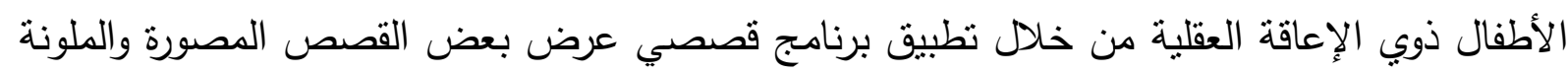

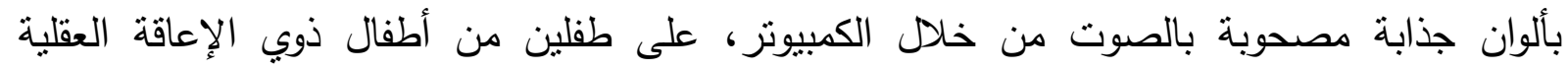
البسيطة؛ لتعليمهما مهارات ما قبل القراءة، وطلب من كل طفل إعادة سرد القصة، ووصف الصورة

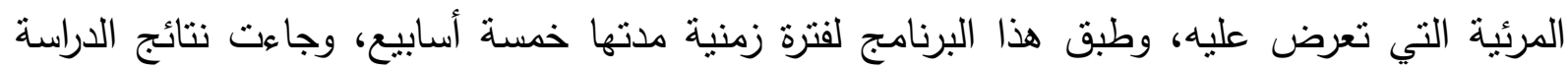
تؤكد تحقيق البرنامج القصصي المقدم للطفلين الهدف الذي صمح من أجله، وهو تتمية مهارات ما قلهبل القراءة، كما أوصت الدراسة بضرورة تصميم برامج نقدم للأطفال ذوي الإعاقة العقلية من خلاد القصنة لتتمية مهاراتهم وعلاج مشكلاتهم التي يعانون منها.

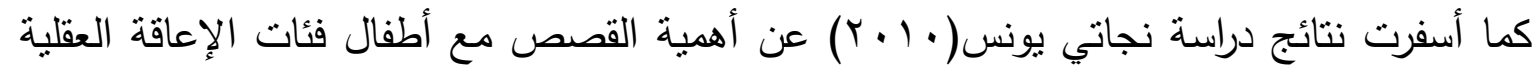
البسيطة، واضطراب طيف التوحد، وذوي صعوبات التعلم في تتمية السلوكيات الاجتماعية الآتية، وهي:

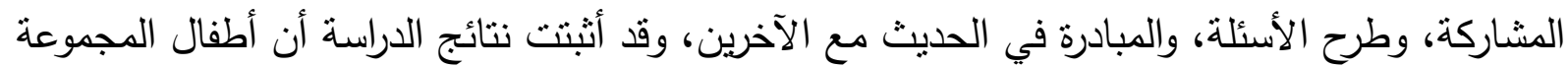

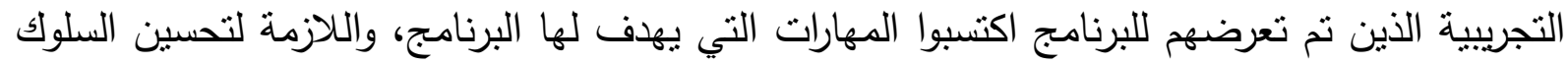

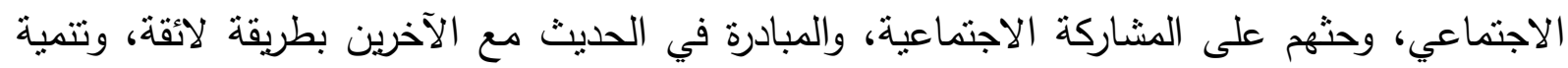

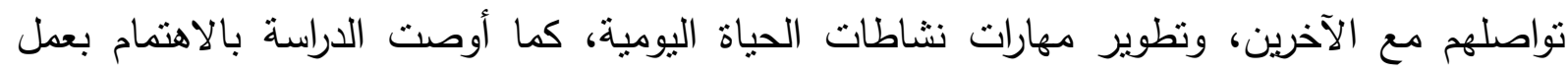

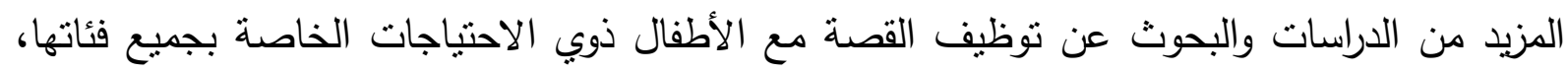
ومنهم فئة الأطفال ذوي الإعاقة العقلية، وتصميم برامج تلبي احتياجاتهم، وتحد مشكلاتهم، وتسعى لحلها. وفي هذا السياق أثنتت نتائج دراسة ورينتشر وتيست Richter \& Test 2011) فاعلية برنامج قصصي تم توظيفه مع ثلاثة من البالغين من ذوي الإعاقة العقلية البسيطة؛ لتتمية مهاراتهم وتعديل

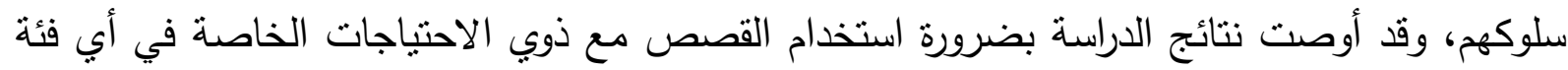
عمرية، وبالأخص مع الأطفال ذوي الاحتباجات الخاصة، ومنهم فئة ذوبي الإعاقة العقلية لإكسابهم

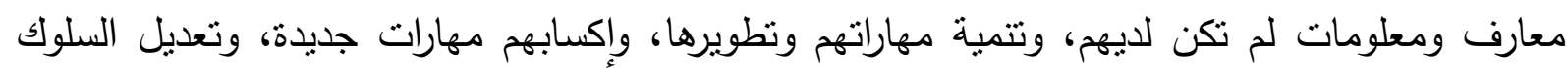
الخطأ لديهم.

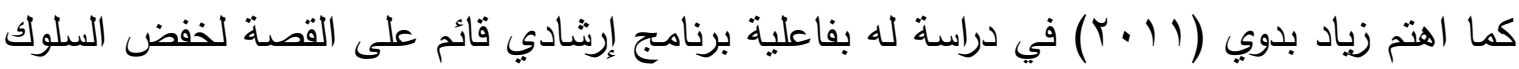

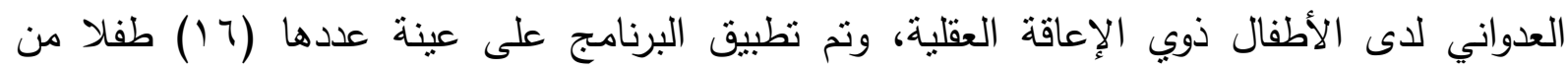

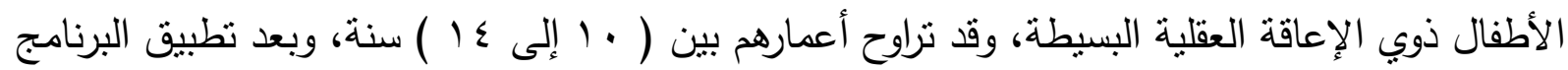

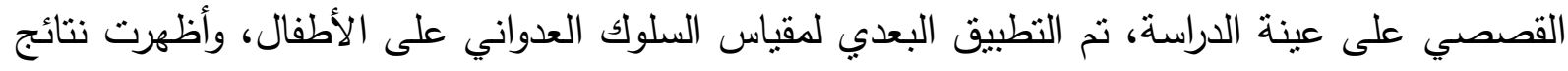

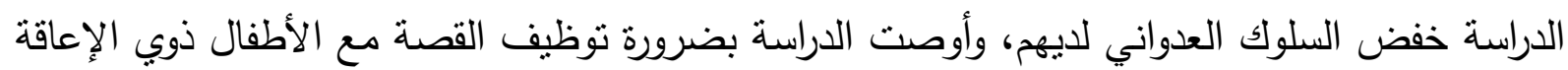
العقلية، وضرورة حث معلمين ومعلمات الثربية الخاصة على استخدامها مع أطفال الفئات الخاصة. 
وأكدت مرفت محمد (11) ـ ب) في دراسة لها فاعلية القصص في إكساب بعض المهارات الاجتماعية، ومنها: تكوين صداقات، والتعاون، ومساعدة الذات على عينة قوامها (7 (1) طفلا مع أطفال ذوبي الإعاقة

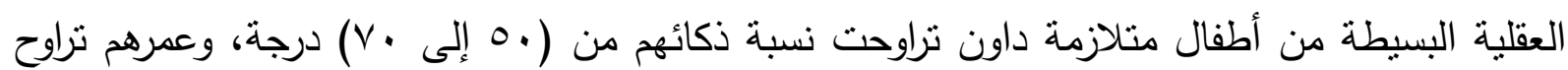

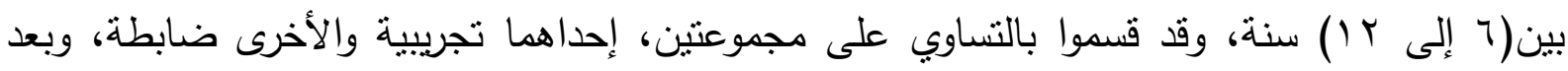

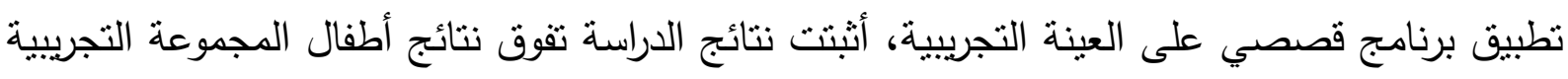

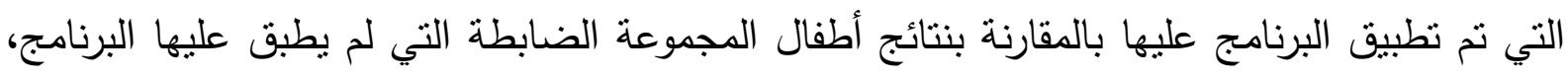

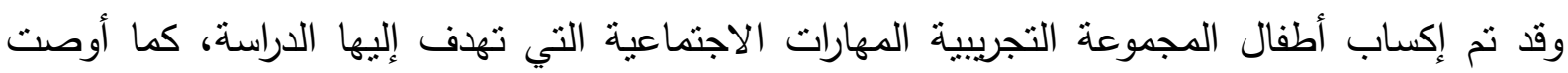

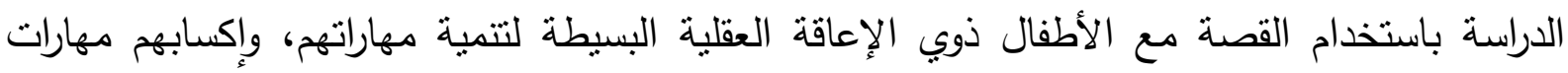
جديدة يحتاجون إليها في حياتهم.

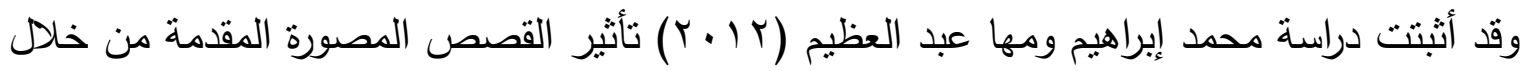

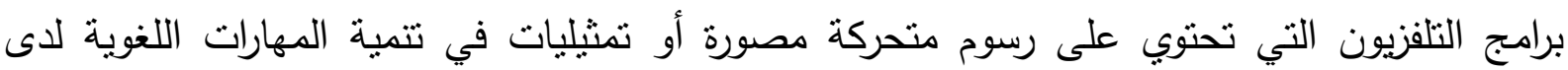

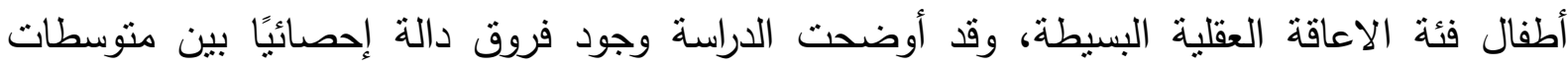

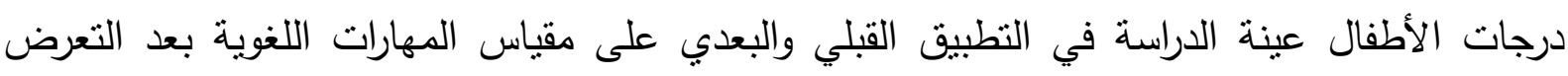

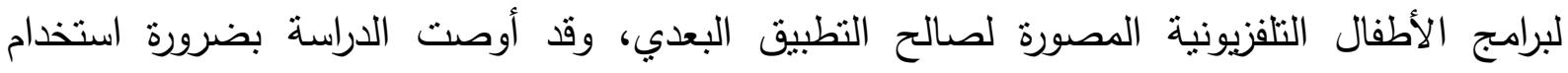
القصص في البرامج المقدمة للأطفال ذوبي الإعاقة العقلية.

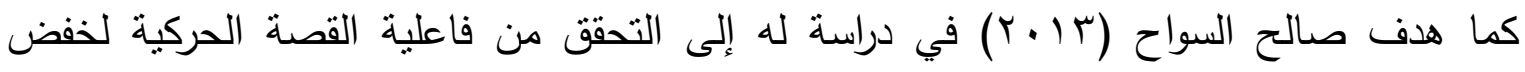

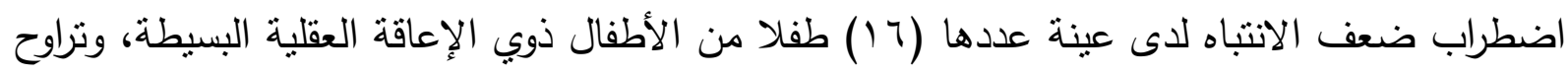

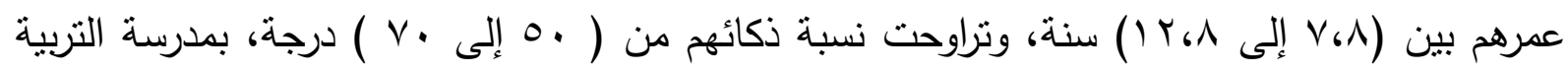

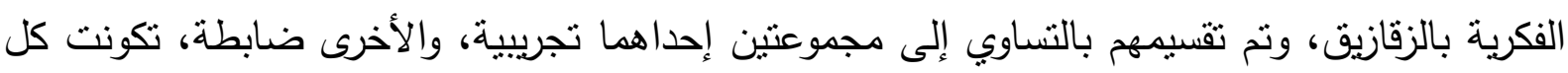

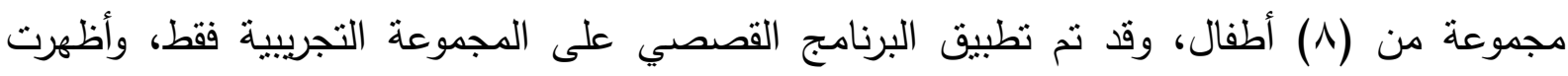

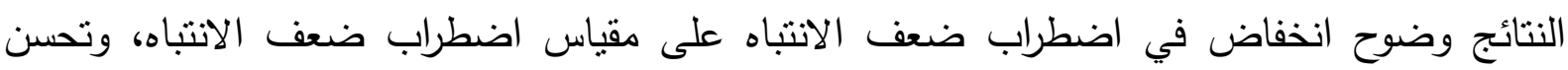

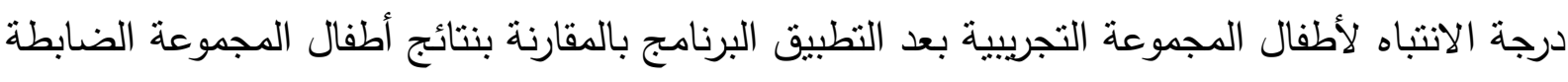

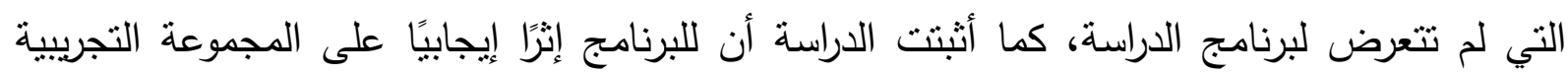
خلال فترة المتابعة لهم، كما أوصت الدراسة بضرورة استخدام القصة مع الأطفال ذوي الإعاقة العقلية. وقد أكدت دراسة منى عمران (ع ( ب) فاعلية برنامج قصصي مقدم لتتمية مهارات التواصل لدي

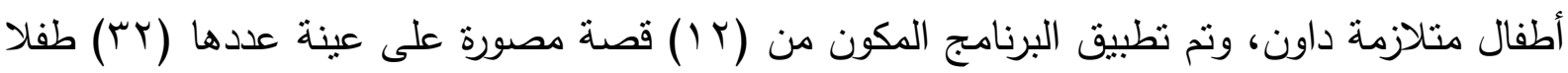

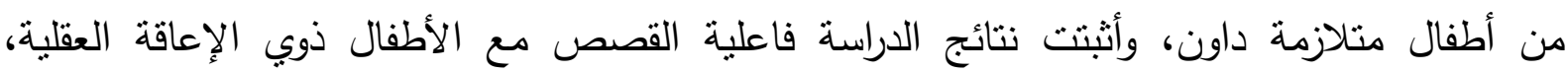
وأوصت بضرورة استخدامها مع الأطفال ذوي الإعاقة العقلية، ومنهم أطفال متلازمة داون. 
وقد هدفت دراسة وفاء العقيلي (1 ب) إلى التعرف علي أهية استخدام القصص المصورة لتتمية

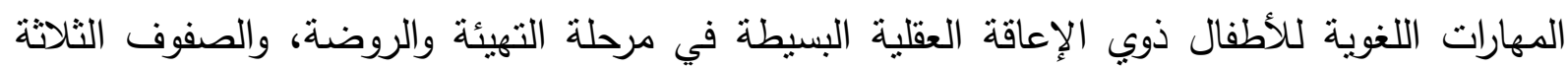

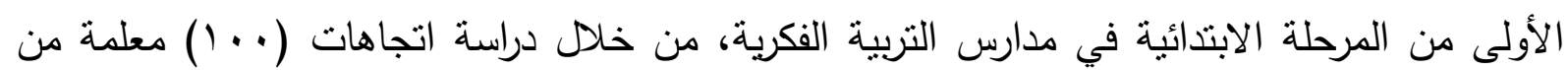
معلمات التربية الخاصة لأهم الاستراتيجيات المستخدمة مع الأطفال ذوبي الإعاقة العقلية بمحافظة

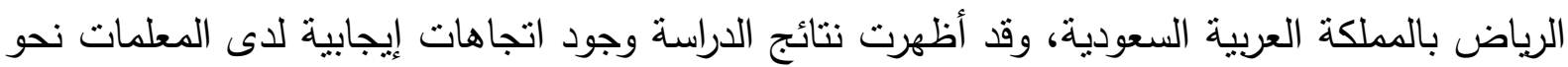
استخدام القصص المصورة في العملية التعليمية، كما أن القصص المصورة لها دور كبير في تتمية المهارات اللغوية لهؤلاء الأطفال، وقد أوصت الدراسة القائمين على التربية والتعليم بمدارس التربية الفكرية

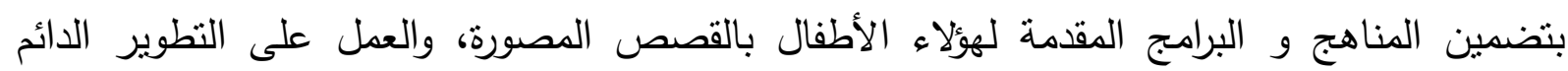

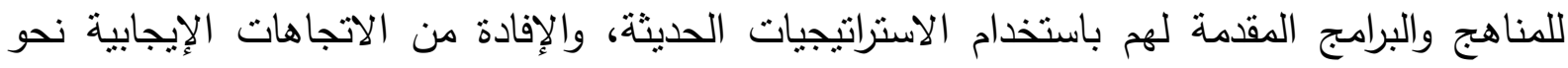

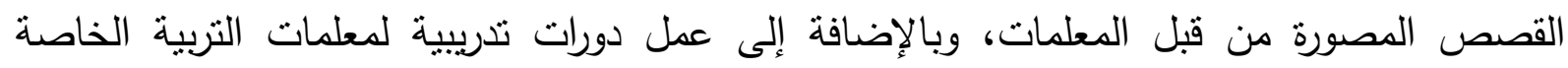

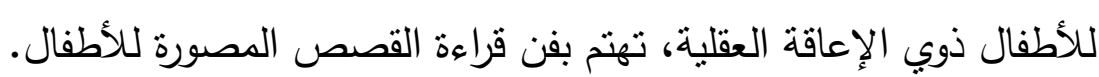
وقد تم الحصول على عدد من الدراسات أكدت على فاعلية القصة في إكساب السلوكيات الصحية،

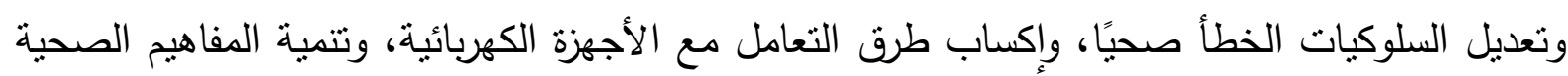

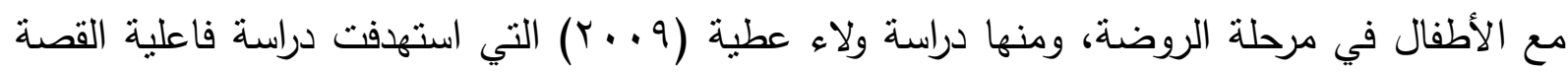

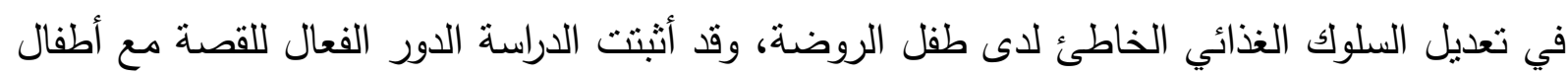

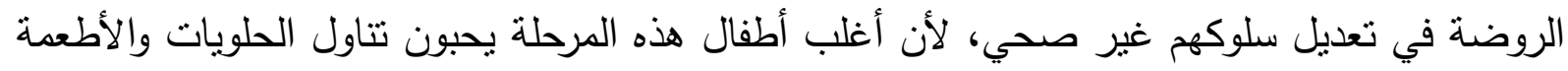

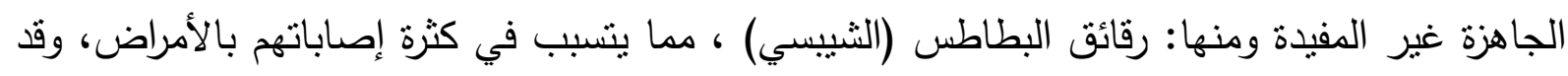

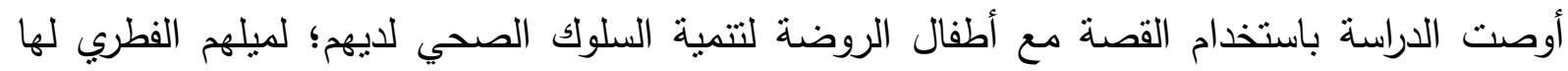
وملاءمتها مع أطفال هذه المرحلة.

كما توصلت دراسة سحر نسيم (1) (1) إلى فاعلية برنامج قائم على عدة استراتيجيات منها القصة

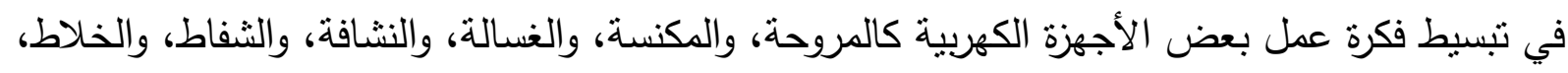

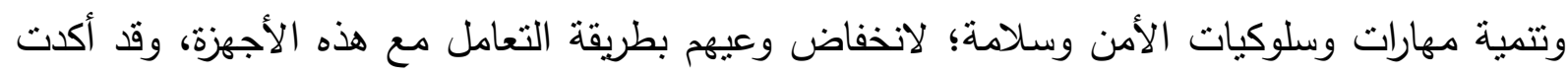

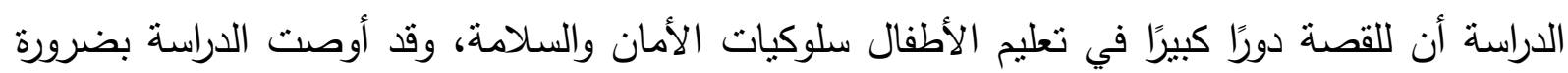
إكساب مهارات السلامة والأمان للأطفال.

كما هدفت دراسة فاطمة شعبان وفايزة يوسف (1) • ب) إلى التعرف على فاعلية استخدام الأنشطة القصصية الحسية والإلكترونية في إكساب التقافة الغذائية لاى طفل الروضة بمنطقة نجران، وتم تطبيق

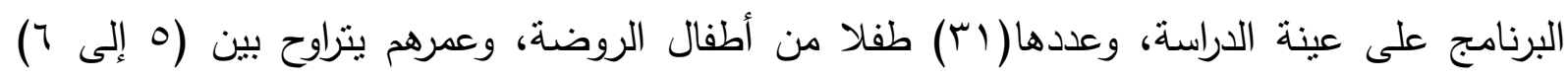

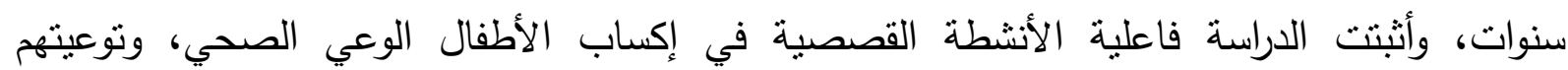


بمكونات الغذاء، والتوعية بأمراض سوء التغذية، وقد تحقق إكساب التقافة الصحية الغذائية للأطفال لاعتماد البرنامج على الأنشطة القصصية التي يتوافر بها عناصر المتعة وجذب الانتباه.

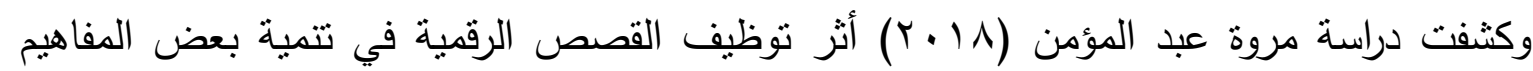
الصحية، وهي: النظافة الثخصية (الثعر، والوجه، والأيدي، والأظفار (الأظافر)، والملبس)، والتربية الغذائية( الغذاء الصحي، والعادات الغذائية، وتلوث الغذاء، والباعة المتجولون)، والعادات الصحية السليمة، وتم تطبيق برنامج الدراسة على عينة من أطفال الروضة عددها (• ع) طفلا بمدينة المزاحمية بالسعودية، وتراوح عمرهم من( إإلى 7 ) سنوات، قسموا على مجموعتين تجريبية التي تم تطبيق عليها برنامج الدراسة، والأخرى المجموعة الضابطة والتي لم تتعرض للبرنامج، وقد توصلت الدراسة إلى تقوق نتائج أطفال المجموعة التجربيية على نتائج أطفال المجموعة الضابطة، وأوصت الدراسة بضرورة الاهتمام بتصميم برامج وأنشطة تساعد على إكساب التربية الصحية لأطفال الروضة، وعمل دورات لمعلمات الروضة عن التربية الصحية للأطفال، وتوظيف القصة لتعليم الطفل الروضة المفاهيم الصحية. ويتضح مما سبق تعدد الدراسات التي أثنتت فاعلية القصة مع الأطفال العاديين ومع الأطفال ذوي الاحتياجات الخاصة، كما تم الحصول على دراسات أثنتت فاعلية القصة مع أطفال ذوي الإعاقة العقلية،

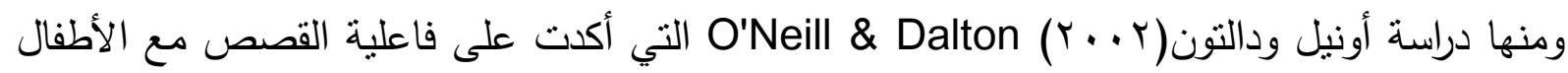
ذوي الإعاقة العقلية لتعليمهم مهارات ما قبل القراءة، ودراسة نجاتي يونس(• (ب) التي أسفرت عن أهمية القصص لتتمية السلوكيات اللازمة لتحسين سلوكهم الاجتماعي، وتتمية تواصلهم مع الآخرين، ودراسة ريتشتر وتيست Richter \& Test (2011) التي أثبتت فاعلية القصص في تتمية مهاراتهم وتعديل سلوكهم، ودراسة زياد بدوي (1) (1) التي أثنتت فاعلية برنامج قائم على القصة لخفض السلوك العدواني لديهم، ودراسة مرفت محمد (11 • (Y) التي أوصت بفاعلية القصص في إكسابهم بعض المهارات الاجتماعية، ومنها: (تكوين صداقات، والتعاون، ومساعدة الذات)، ودراسة محمد إبراهيم ومها عبد العظيم

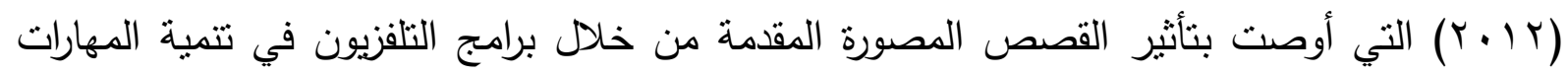
اللغوية، ودراسة صالح السواح (r (r) التي أثتتت فاعلية القصة الحركية لخفض اضطراب ضعف

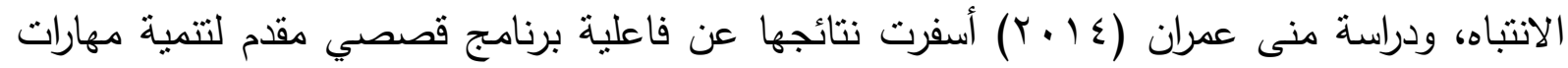
التواصل لديهم، ودراسة وفاء العقيلي (T 1 • ( التي أكدت على أهمية استخدام القصص المصورة لتتمية المهارات اللغوية لديهم، ولم تجد الباحثة - في حدود علمها - دراسة تتاولت فاعلية القصة في تتمية الوعي الصحي لأطفال الروضة ذوي الإعاقة العقلية البسيطة، بالرغم من قصور الأطفال الروضة ذوي الإعاقة العقلية البسيطة في الوعي الصحي، واحتياجه الثديد لبرامج التربية الصحية التي تقدم لهم بطرق تتلاعم مع خصائصهم، ما دعا لهذه الدراسة . 
فيما يلي ينت تتاول الإجراءات التي أتبعت في تحديد عينة الدراسة، وخطوات إعداد البرنامج القصصي، وإعداد مقياس الوعي الصحي لاى أطفال الروضة ذوبي الإعاقة العقلية البسيطة، وتتفيذ تجربة

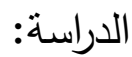

\section{أولاً: تحديد عينة الدراسة:}

تكونت عينة الدراسة من أطفال الروضة ذوي الإعاقة العقلية البسيطة في المستوى الثاني روضة

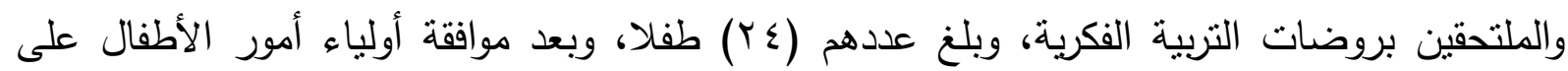

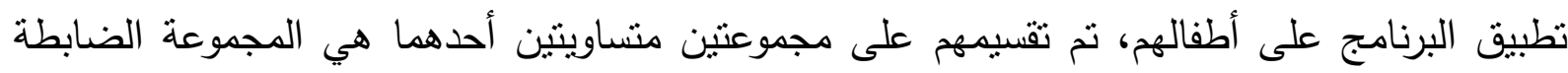

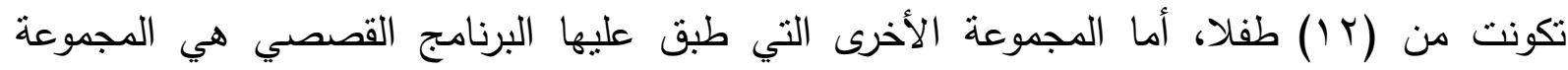
التجريبية تكونت من (r I ( طفلا، وقد نم اختيارهم وفق الثروط الآتية:

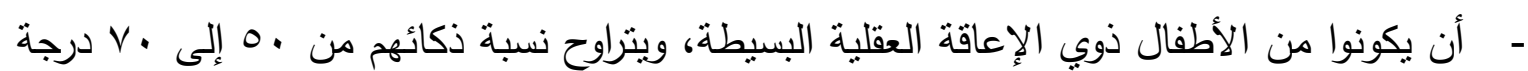
على اختبار ستانفورد بينيه الصورة الخامسة صفوت فرج (1) (1)، وقد تم الإستعانة بالأخصائيين النفسيين بمدارس التربية الفكرية بمدرستي الرمل الميري وأحمد شوقي، والأخصائيين

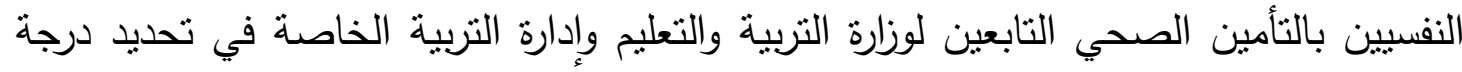

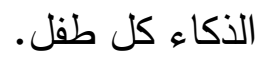
- ل ال العانون الأطفال من إعاقات حسية أو حركية.

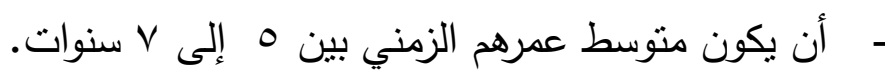

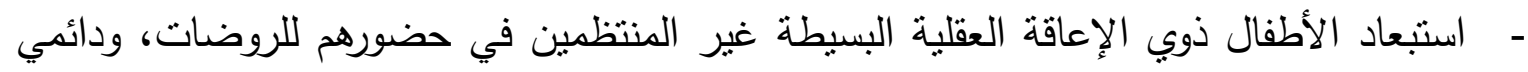

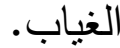
- - أن يقيم كل طفل إقامة دائمة مع الوالدين، ويتم استبعاد حالات الأطفال المقيمة مع الأسر البديلة. - - ملو الوالدين من الإعاقات بكافة أنواعها.

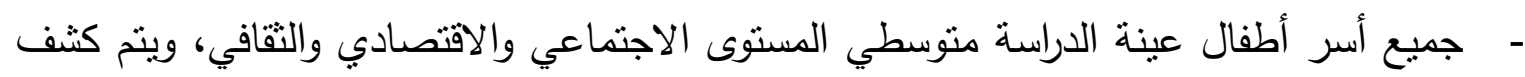

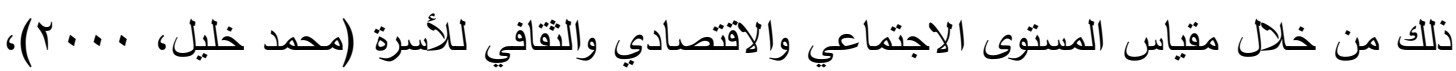
وتم الاستعانة بالأخصائيين الاجتماعيين بمدرسة الرمل الميري ومدرسة أحمد شوقي في تحديد ذلك. - تكافؤ نتائج أطفال المجموعة الضابطة وأطفال المجموعة التجريبية في نسبة الذكاء، والعمر الزمني، والمستوي الاجتماعي والاقتصادي والثقافي للأسر . 
- - تكافؤ نتائج أطفال المجموعة الضابطة وأطفال المجموعة التجريبية في مستوى الوعي الصحي

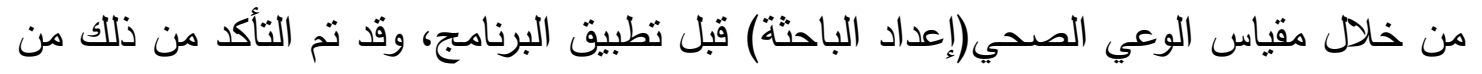

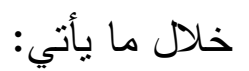

\section{التطبيق القبلي لمقياس الوعي الصحي:}

طُُق مقياس الوعي الصحي على مجموعتي الدراسة الضابطة والتجريبية، وذللك خلال الفترة من

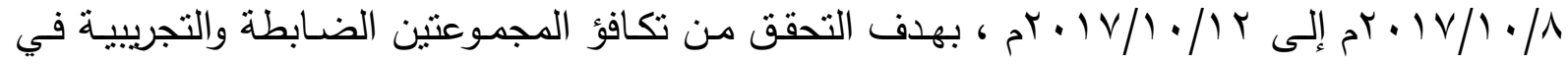

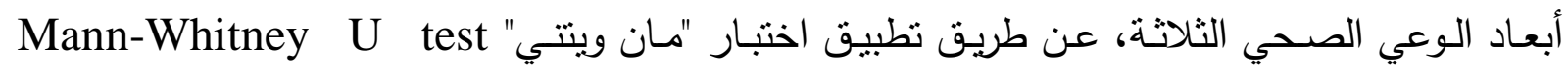

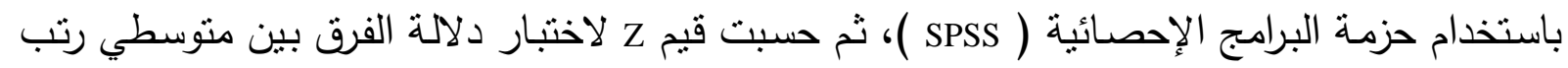

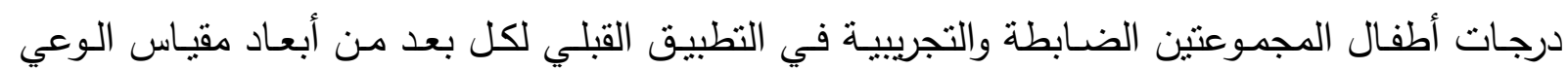
الصحي ولأبعاد المقياس مجتمعة، ويوضح جدول ( ) قيم Z ، ودلالتها لكل اختبار :

جدول (1) (1) قيم Z لاختبار دلالة الفرق بين متوسطي رتب درجات أطفال المجموعتين الضابطة والتتجريبية في التطبيق القبلي لكل بعد من أبعاد مقياس الوعي الصحي وأبعاد المقياس مجتمعة لونة

\begin{tabular}{|c|c|c|c|c|c|c|c|}
\hline مستوى الالالة & قيمة Z & 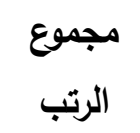 & متوسط & الأطفال & المجموعة & أبعاد مقياس الوعي الصحي & p \\
\hline \multirow{2}{*}{ غير دال } & \multirow{2}{*}{-1.022} & . & $11, \cdot \varepsilon$ & \multirow{8}{*}{ Ir } & الضابطة & \multirow{2}{*}{ بعد النظافة الشخصية. } & \multirow{2}{*}{1} \\
\hline & & $17 \vee, 0$. & $1 T, 97$ & & التجريبية & & \\
\hline \multirow{2}{*}{ غير دال } & \multirow{2}{*}{-1.258} & $\mid r \wedge, 0$. & $1 \cdot, v 1$ & & الضابطة & \multirow{2}{*}{ بعد التغذية السليمة. } & \multirow{2}{*}{$r$} \\
\hline & & $|v|, 0$. & $1 \leq, r q$ & & التجريبية & & \\
\hline \multirow{2}{*}{ غير دال } & \multirow{2}{*}{-0.907} & $170,0$. & $1 \%, \vee q$ & & الضابطة & \multirow{2}{*}{ بعـــــــالوقايــــة مـــن الأمـــراض } & \multirow{2}{*}{$r$} \\
\hline & & $1 \pi \leqslant, 0$. & $\mid 1, Y)$ & & التجريبية & & \\
\hline \multirow{2}{*}{ غير دال } & \multirow{2}{*}{-0.348} & $1 \leq \varepsilon$ & Ir & & الضابطة & \multirow{2}{*}{ 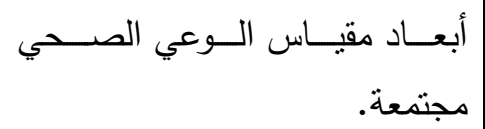 } & \multirow{2}{*}{$\varepsilon$} \\
\hline & & 107 & r & & التجريبية & & \\
\hline
\end{tabular}

يتضح من جدول (1) تكافؤ المجموعتين الضابطة والتجريبية في أبعاد مقياس الوعي الصحي الثلاثة والمقياس ككل، حيث إن قيم Z غير دالة في كل بعد من أبعاد المقياس. ثانياً: إعداد البرنامج:

تم بناء البرنامج في ضوء جعل أطفال الروضة ذوي الإعاقة العقلية البسيطة محور العطلية التعليمية متفاعلين وايجابين باستمرار، مراحل إعداد البرنامج القصصي، هي: مرحلة الدراسة والتحليل، ومرحلة 
الإعداد والتصميم، ومرحلة الإنتاج، ومرحلة التحكيم والتجريب، ومرحلة التطبيق، ومرحلة التقويم، وسوف يتم وصف كل مرحلة من هذه المراحل:

r-

ץ-1-1 - تحديد الههف العام للبرنامج: هدف البرنامج هو تتمية الوعي الصحي لدى أطفال

الروضة ذوي الإعاقة العقلية البسيطة.

r-1-r-r-تحليل خصائص المتعلمين: لتحليل خصائص أطفال الروضة ذوي الإعاقة العقلية

البسيطة، قد تم ذلك من خلال ما يلي:-

- نم الاطلاع على الأدبيات والدراسات والبحوث السابقة في مجال التربية الخاصة،

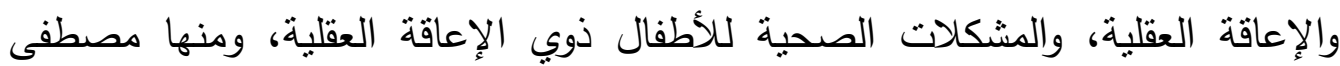

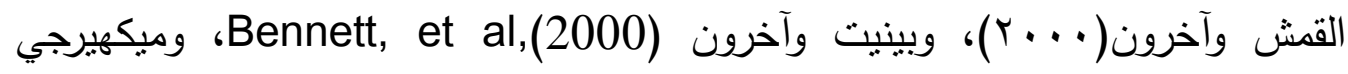

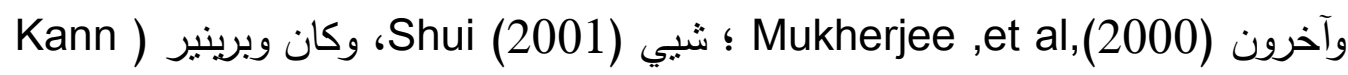

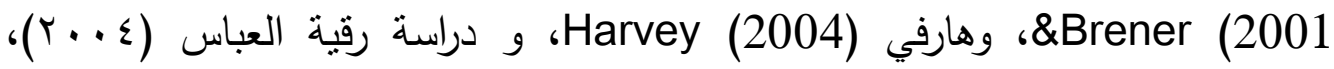

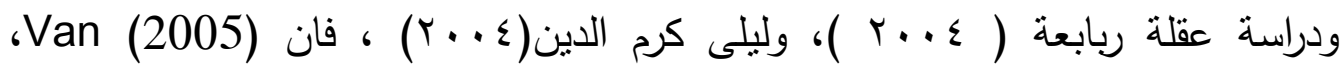

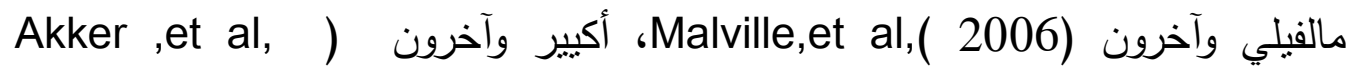

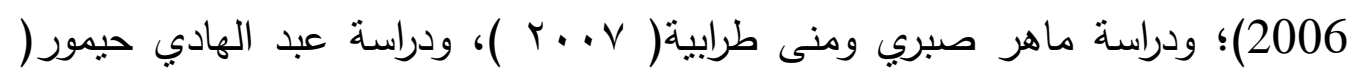

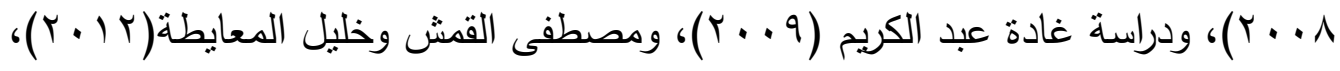

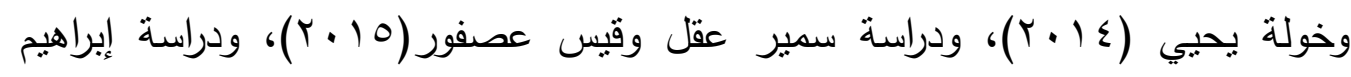

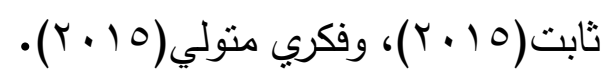

- مقابلات متعددة مع بعض أسر أطفال الروضة ذوبي الإعاقة العقلية البسيطة، ومعلمات

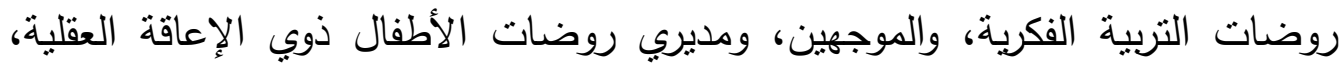

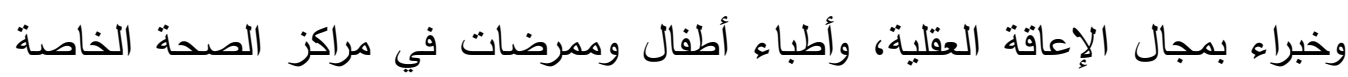
بمرحلة الطفولة. - تم عمل عدة زيارات ميدانية لروضات التربية الفكرية لأطفال ذوي الإعاقة العقلية

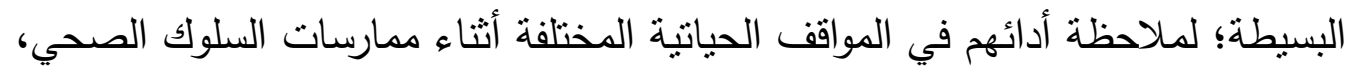
ولتحديد جوانب قصورهم في الوعي الصحي. وقد تم الاستفادة مما سبق في تحديد خصائص الأطفال الروضة ذوي الإعاقة العقلية، فيما يأني: 


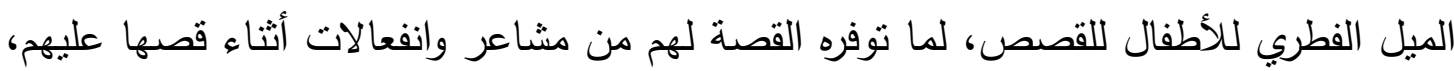

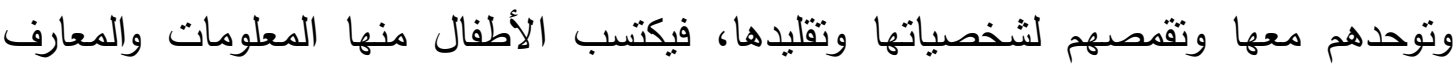
والاتجاهات نحو السلوكيات الصحيحة، كما تساعدهم على ممارسة السلوك الصحي بشكل سليم. بالرغم من أن أطفال الروضة ذوبي الإعاقة العقلية البسيطة ينتمون إلى فئة واحدة وهي فئلة

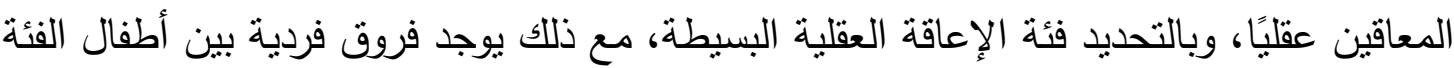
الواحدة، فلذلك يجب عدم مقارنة أداء طفل منهم بأداء زميله، وإنما يجب مقارنة الطفل بنفسه.

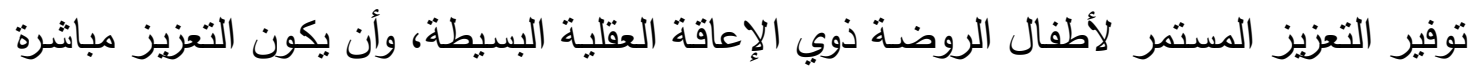

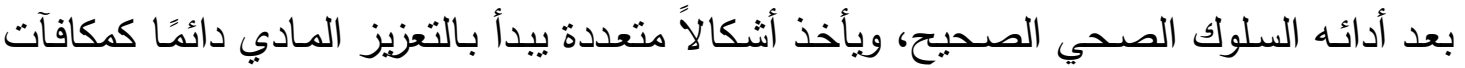

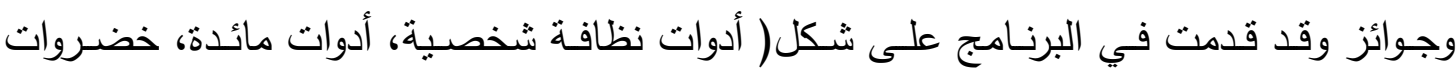

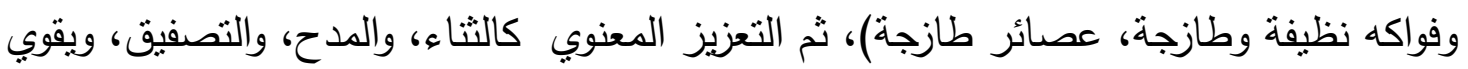
التعزيز الاستجابات السلوكية الصـية الصـحيحة ويثبيتها، كمـا يكون لدى الطفل الاتجاهـات الإيجابية نحو ممارسة السلوك الصحي، كما يجعل التعزيز الطفل يشعر بالثقة بالنفس والثعور

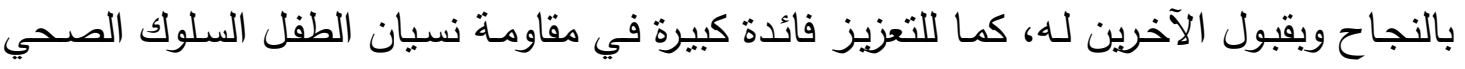
الصحيح الذي تم إكسابه. ميل الأطفال إلى التقليد والمحاكاة يجب أن نستغله من خلال حرص المعلمة أن تكون قدوة

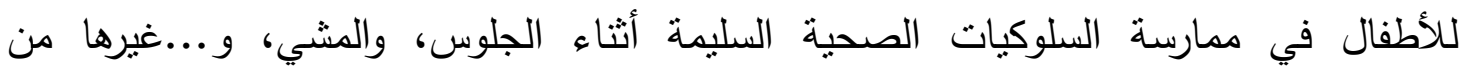

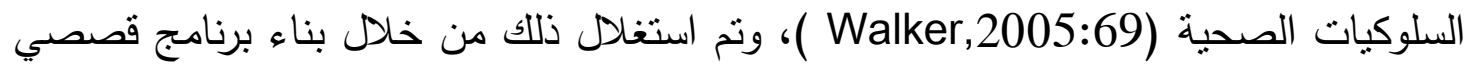
يقلد الطفل أبطالها ويحاكيهم في أداء سلوكهم الصحي.

r-1-r- تصديد أبعاد الوعي الصحي التي يحتاجها أطفال الروضة ذوي الإعاقة العقلية البسيطة لتنميتها: وتم اتباع الخطوات النالية :

- الأطلاع على العديد من الدراسات السابقة والمراجع في مجال برامج التربية

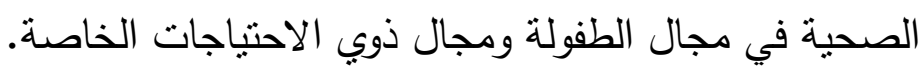

- عمل عدة مقابلات مع الخبراء في مجال تربية الطفل وذوي الاحتياجات الخاصة والمعاقين عقليًا، وأولياء أمور الأطفال ذوي الإعاقة العقلية، ومعلمات روضات التربية الفكرية؛ لأخذ أرائهم في تحديد أبعاد الوعي الألياء الصحي التي تلاءم أطفال الروضة ذوي الإعاقة العقلية. - عمل عدة زيارات ميدانية لملاحظة الأطفال الروضة ذوي الإعاقة العقلية البسيطة لحصر احتياجاتهم للوعي الصحي. 
وقد نتج عن ما سبق تحديد أبعاد الوعي الصحي التي يحتاجها أطفال الروضة ذوي الإعاقة العقلية البسيطة تتميتها، وهي:

أولاً: بعد النظافة الثخصية.

ثانيًا: بعد التغذية السليمة.

ثالثًا: الوقاية من الأمراض والمخاطر.

ومما سبق قد تم الإجابة عن السؤال الفرعي الأول للاراسة، وهو:

• ما أبعاد الوعي الصحي التي يحتاج أطفال الروضة ذوو الإعاقة العقلية البسيطة إلى تنميتها؟

ץ-1- - - تحديد قائمة بالمعارف والاتجاهات والسلوكيات الصحية التي يحتاج إليها أطفال الروضة

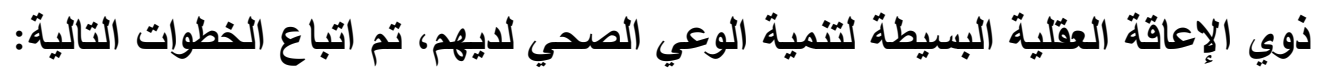

ץ-1- -1- - تحديد الهدف من القائمة :تهدف هذه القائمة إلى تحديد أهم المعارف والاتجاهات والسلوكيات الصحية التي يحتاج إليها أطفال الروضة ذوي الإعاقة العقلية البسيطة لتنمية الوعي

الصحي لديهم، والتي سوف يينى عليها البرنامج القصصي الدقدم إليهم لتتمية الوعي الصحي.

r-1- צ- - تحديد محتوى القائمة : لتحديد المعارف والاتجاهات والسلوكيات الصحية التي يحتاج إليها

أطفال الروضة ذوي الإعاقة العقلية البسيطة، تم الاستعانة بما يأني :

- الاطلاع على الأدبيات والبحوث والدراسات السابقة في مجال الإعاقة العقلية، ومجال برامج

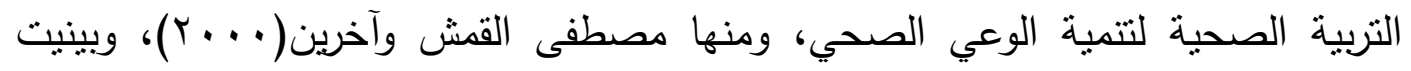

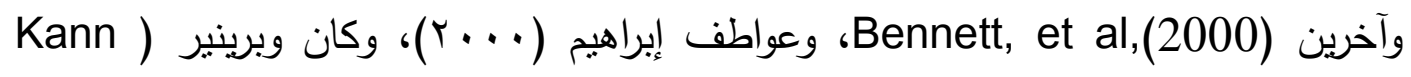

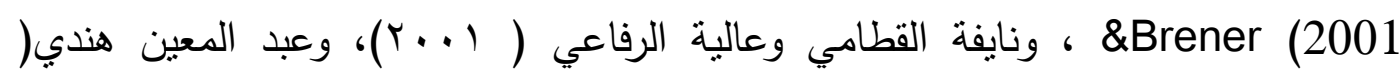

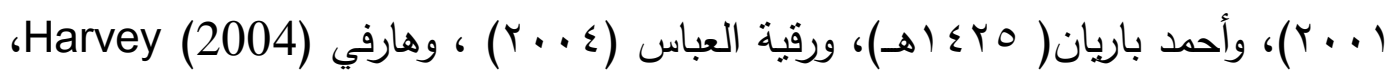

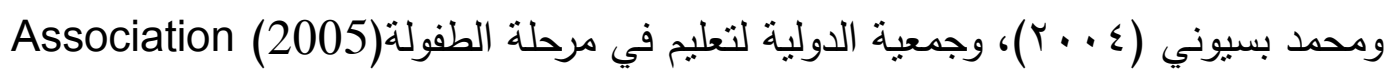
for Childhood Education International

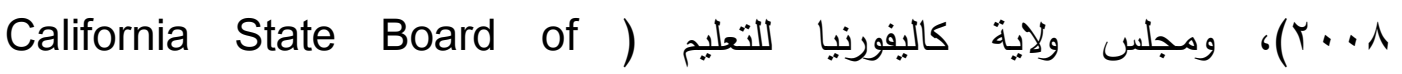

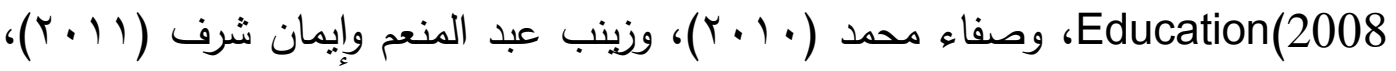
وسمير عقل وقيس عصفور (10 + (1)، ومؤسسة برامج الطفولة بوزارة الصحة الفلسطينية

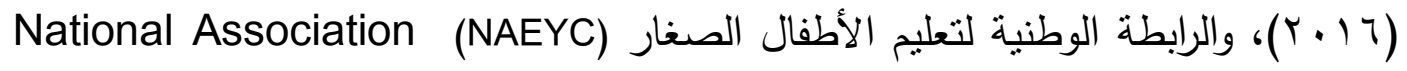
.for The Education of Young Children(2017) 
- إجراء العديد من المقابلات مع خبراء في مجال الإعاقة العقلية، وخبراء في مجال برامج

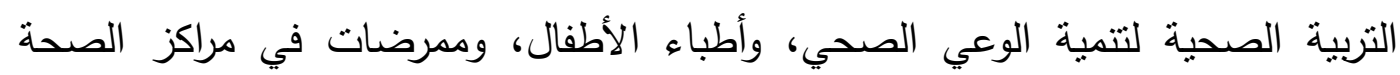

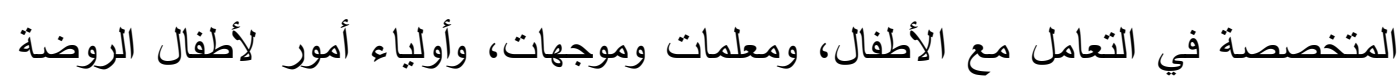
ذوب الإعاقة العقلية؛ لأخذ أراءهم في السلوكيات الصحية التي يحتاجها هؤلاء الأطفال.

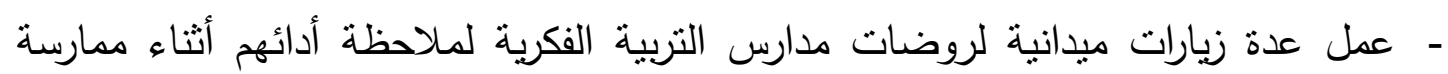
السلوكيات المرتبطة بالصحة؛ لتحليلها ولتحديد المعارف، والاتجاهات، والسلوكيات الصحية

$$
\text { التي يحتاجون إلى تتميتها. }
$$

- - حصر المعارف والاتجاهات والسلوكيات الصحية التي يحتاجها أطفال الروضة ذوي الإعاقة

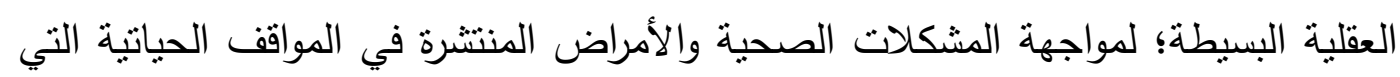

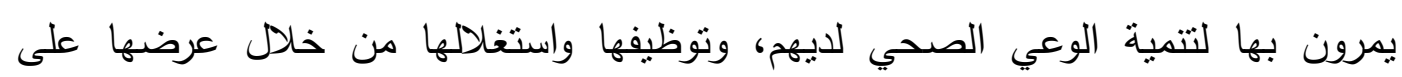

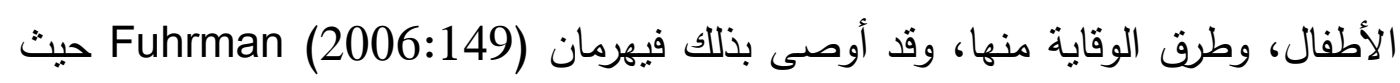

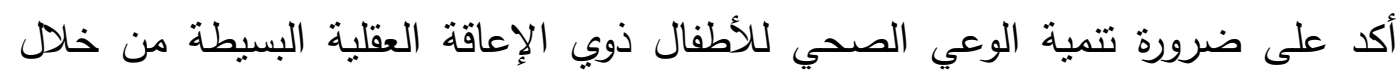

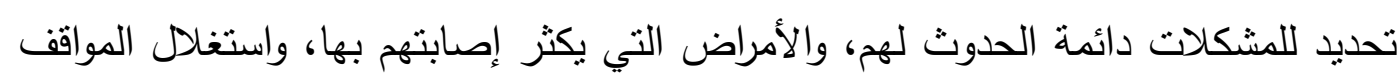

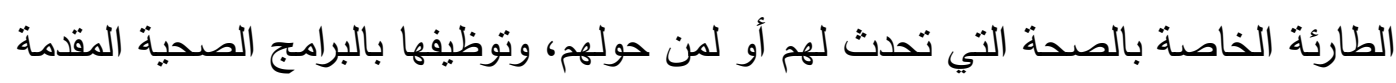

$$
\text { لتتمية الوعي الصحي لهم. }
$$

قائمة بالمعارف والاتجاهات والسلوكيات الصحية التي يحتاج إليها أطفال الروضة ذوي الإعاقة العقلية البسيطة لتمية الوعي الصحي لايهم، في ضوء الأبعاد التالية :

أولًا: المعارف والاتجاهات والسلوكيات الصحية التي يحتاجها أطفال الروضة ذوي الإعاقة العقلية

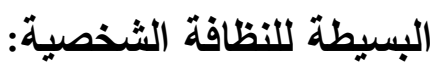

- معلومات عن أهمية النظافة الثخصبة. - معلومات عن أدوات النظافة الثخصية (مشط وفرشاة للشعر - فرشاة أسنان - فوطة ).

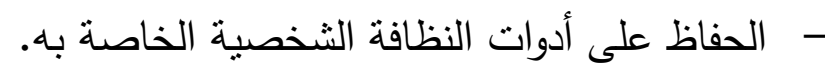

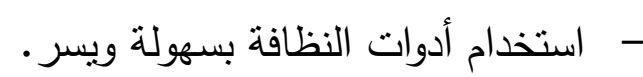
- - نظافة الثعر وتمشيطه باستمرار . - غ غل الوجه باستمرار ( مرنين في اليوم على الأقل ، وعند الحاجة). - - غسل اليد بعد استخدام دورات المياه. - تغير الملابس باستمرار ( الداخلية، والخارجية، والجوارب). - تفريش الأسنان يوميًا ( مرتين في اليوم قبل النوم ليلًا، وبعد النوم صباحًا).

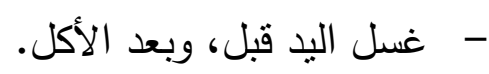


- - الاستحمام مرتين في الأسبوع، وعند اللزوم. - - - استخدام المرآة لتتسيق الملابس والثعر • - - تقليم الأظفار (الأظافر باستخدام مبرد خشب). - - تكوين اتجاهات ايجابية نحو النظافة الثخصية. - - الحرص على النظافة الثخصية باستمرار .

ثاتيًا: المعارف والاتجاهات والسلوكيات الصحية التي يحتاجها الأطفال ذوي الإعاقة العقلية البسيطة

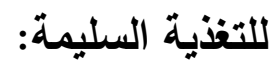

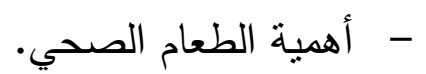
- - - استخدام أدوات المائدة الثخصية. - - تتاول كمية الطعام الصحي المتوازن لجسم الطفل، وطوله. - تحضير بعض الأطعمة بمفردة (كسندوينش، وسلطة).

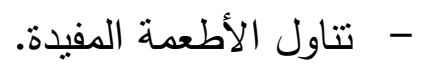

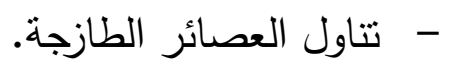

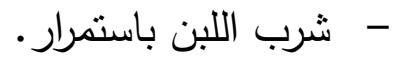

- التتوع في تتاول العناصر الغذائية المختلفة المفيدة. - - التأكد من نظافة الطعام كغسل الخضروات والفاكهة قبل الأكل. - - مرب ماء بكميات مناسبة.

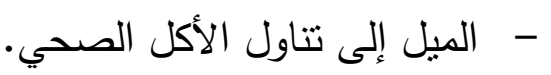

ثالثًا: المعارف والاتجاهات والسلوكيات الصحية التي يحتاجها الأطفال ذوي الإعاقة العقلية البسيطة للوقاية من الأمراض والمخاطر : لمعان - الاهتمام بالحفاظ على النفس من الأخطار والأمراض، وعلى الآخرين.

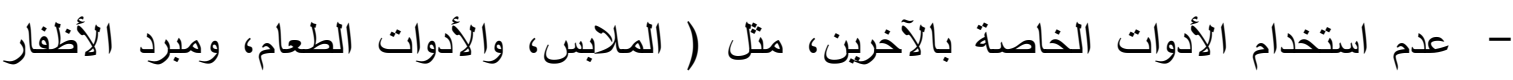
(الأظافر)، والمنشفة، المشط، وفرشاة الأسنان).

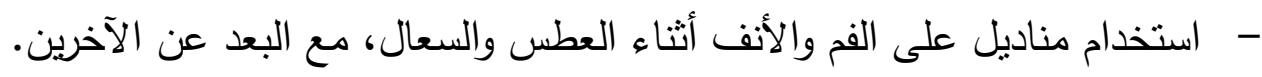
- - عدم تتاول الطعام من الباعة الجائلين.

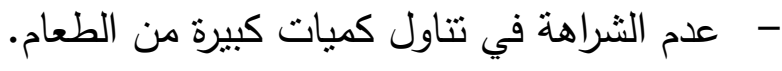

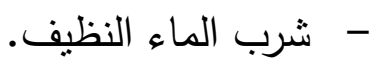
- - تجنب شرب المياه الغازية والعصائر الصناعية الملونة. 
- - تجنب اللعب مع الحيوانات والطيور المشردة.

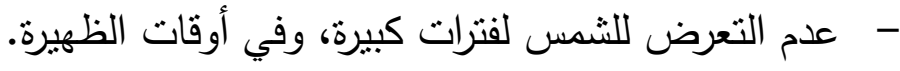

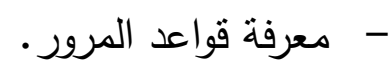

- عدم التجول والاتنقال في الثشارع بمفرده لتجنب حوادث السير •

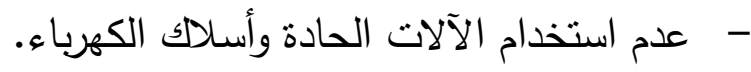
- - الطرق الآمنة لاستخدام الأجهزة الكهربائية بالمنزل.

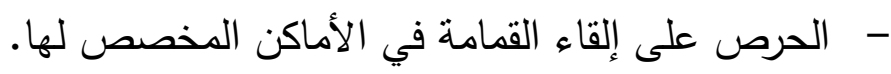
- - الحرص على نظافة المكان الموجود فيه.

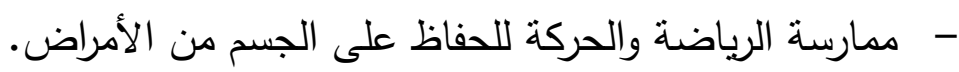
- - الوقوف والجلوس والمشي والجري بطريقة صحيحة. - - - عدم التقاط، وتتاول الطعام من على الأرض. - -

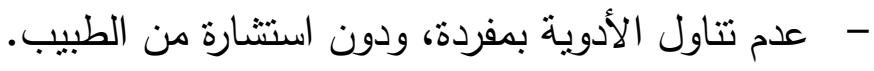

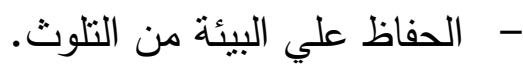

r-

القائمة في صورتها الأولية انتملت على (r) أبعاد أساسية، وهي: - البعد الأول : النظافة الثخصية ، ويتكون من (0) عبارة. - البعد الثاني: التغذية السليمة، ويتكون من (1') عبارة. - البعد الثالث: الوقاية من الأمراض والمخاطر ، ويتكون من (9 (1) عبارة. تمثل القائمة أهم المعارف والاتجاهات والسلوكيات الصحية التي بحتاجها أطفال الروضة ذوي

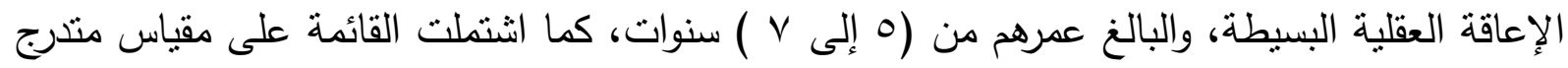
لتقدير مدى أهمية تتاول كل منها، وتدرجت بين الأهمية الكبيرة جداً وانعدام الأهمية كما يلي : مهمة جداً

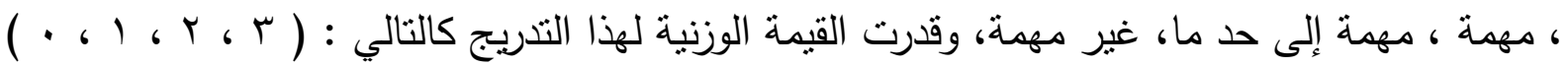

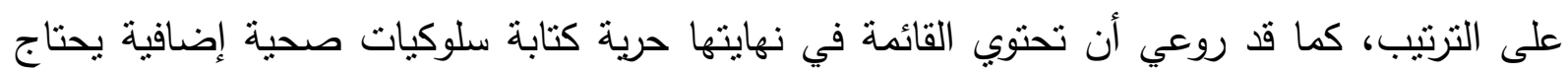
إليها هؤلاء الأطفال من قبل الخبراء، ويوضح جدول (r) تدرج القيمة الوزنية للمعارف والاتجاهات والسلوك الصحي التي يحتاجها هؤلاء الأطفال. 
جدول رقم ( r ) يوضح تدرج القيمة الوزنية للمعارف والاتجاهات والسلوك الصحي

التي يحتاج إليها أطفال الروضة ذوي الإعاقة العقلية البسيطة

\begin{tabular}{|c|c|c|c|c|}
\hline غير مهم & مهم إلى حد & ههم & مهم جدا & المعارف والاتجاهات والسلوك \\
\hline . & 1 & $r$ & $r$ & العبارة \\
\hline
\end{tabular}

r - - - - - - -عرض القائمة على المحكمين :

تم عرض القائمة في صورتها الأولية على مجموعة من المحكمين من الخبراء في مجال الإعاقة

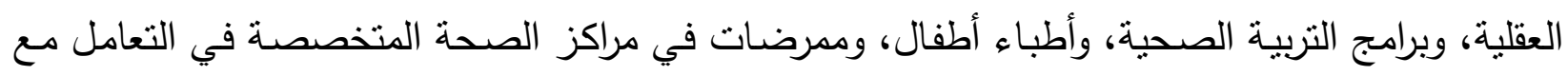
الأطفال، وموجهين، والأخصائيين النفسيين، والمعلمات، وأولياء الأمور لأطفال الروضة ولئة ذوي الإعاقة العقلية

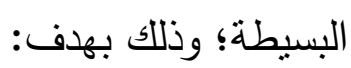

- - تحديد درجة أهمية المعارف والاتجاهات والسلوك الصحي بالقائمة بالنسبة لأطفال الروضة ذوي

الإعاقة العقلية البسيطة.

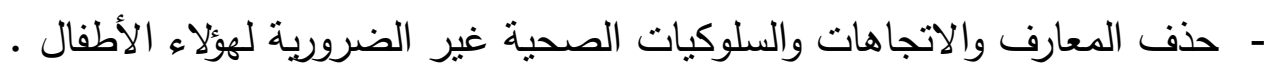
- - إضافة المعارف والاتجاهات والسلوكيات الصحية الضرورية.

وقد أبدى المحكمون ملاحظاتهم وآرائهم حول المعارف والاتجاهات والسلوكيات الصحية بالقائمة، وفيما

- - حذف عبارة من البعد الأول، وهي تحضير بعض الأطعمة بمفرده (كسندويتش، وسلطة)، لأنها

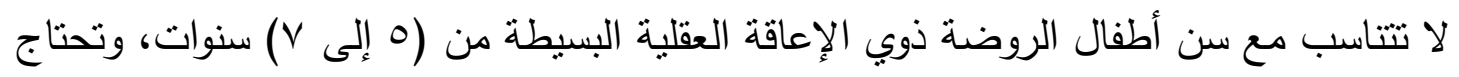

$$
\text { إلى سن أكبر منهم. }
$$

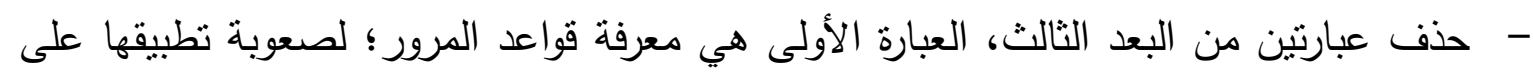

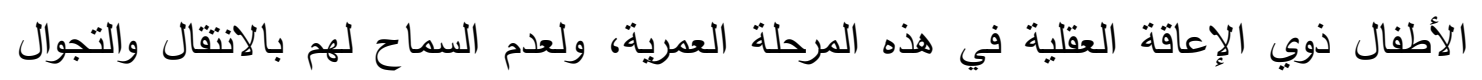

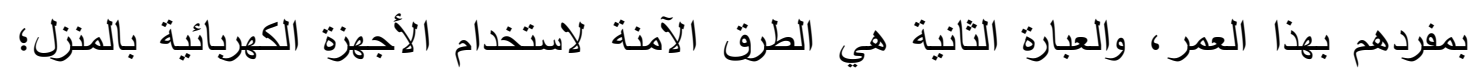

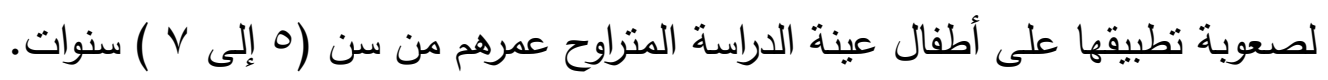

\section{r-1- - - - القائمة في صورتها النهائية :}

وقد نم إجراء التعديلات التي أوصى بها المكمون، وتم اختيار المعارف والاتجاهات والسلوكيات

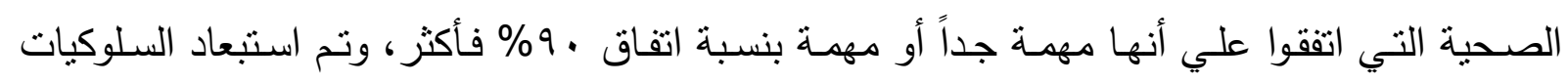
الصحية التي اتفقوا على إنها مهمة إلى حد ما أو غير مهمة، وبذللك تحددت قائمة المعارف والاتجاهات 
والسلوكيات الصحية التي يحتاجها أطفال الروضة ذوي الإعاقة العقلية البسيطة من ( ه إلى V ) سنوات؛ لتتمية الوعي الصحي لديهم في صورتها النهائية.

ومن خلال تحديد قائمة المعارف والاتجاهات والسلوكيات الصحية التي يحتاجها أطفال الروضة ذوي الإعاقة العقلية البسيطة لتتمية الوعي الصحي لديهم ؛ تمت الإجابة عن السؤال الفرعي الثاني للاراسة،

• ما المعارف والاتجاهات والسلوكيات الصحية لكل بعد من أبعاد الوعي الصحي التي يحتاج

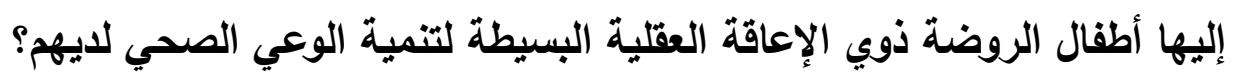

ץ-1-ع - تحديد المصادر المتاحة: تحديد المصادر التي يتم نقديمها لأطفال المجموعة

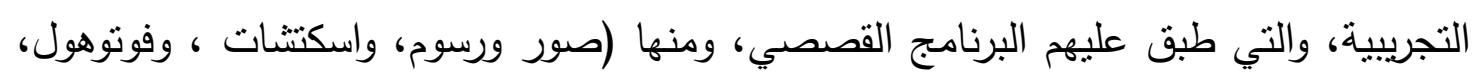

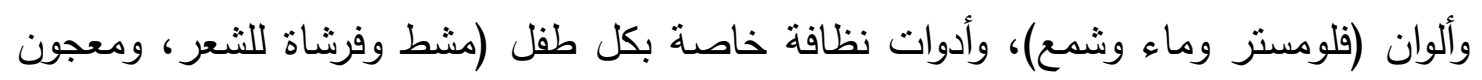

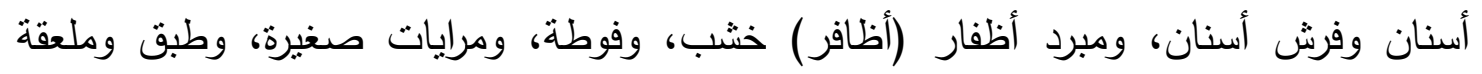

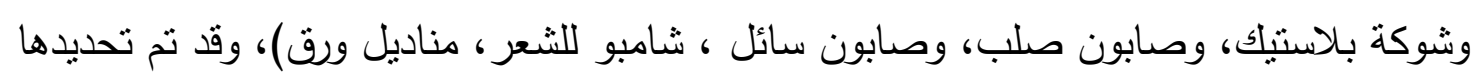

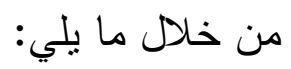

- تحليل خصائص أطفال الروضة ذوي الإعاقة العقلية البسيطة.

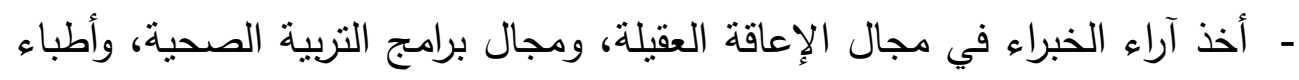

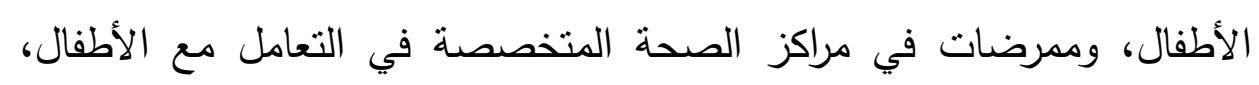

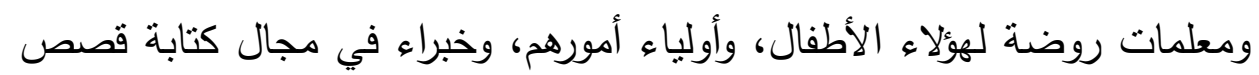
الأطفال ومعلكات - الاطلاع على الأدبيات والبحوث والدراسات السابقة في مجال برامج التربية الصحية ، ومجال قصص الأطفال. - في ضوء قائمة المعارف والاتجاهات والسلوكيات الصحية التي يحتاجها أطفال الروضة ذوو الإعاقة العقلية البسيطة التي تم التوصل لها. r-r - مرحلة الإعداد والتصميم: لهذه المرحلة عدة خطوات، وهي:

r-r-1 - تحديد أهداف البرنامج: يهدف البرنامج القصصي إلى تتمية الوعي الصحي لدى أطفال

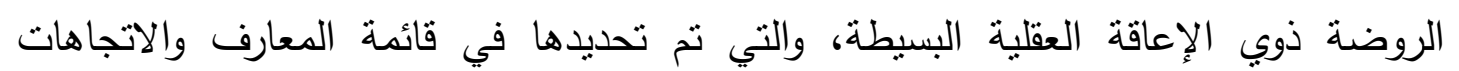
والسلوكيات الصحية التي يحتاج إليها هؤلاء الأطفال، وهي : - - المعارف والاتجاهات والسلوكيات الصحية التي يحتاج إليها الأطفال ذوو الإعاقة العقلية 
- المعارف والاتجاهات والسلوكيات الصحية التي يحتاج إليها الأطفال ذوو الإعاقة العقلية البسيطة للتغذية السليمة. - المعارف والاتجاهات والسلوكيات الصحية التي يحتاج إلبها الأطفال ذوو الإعاقة العقلية البسيطة للوقاية من الأمراض والمخاطر • r - r - r - تحديد محتوى البرنامج: تم تحديد محتوى البرنامج، من خلال ما يأتي: أ. تم الاطلاع على العديد من الأدبيات والدراسات والبحوث السابقة المهتمة بيرامج التربية الصحية لتتمية الوعي الصحي في مجال الطفولة، ومجال ذوي الاحتياجات الخاصة للاستفادة منها فيما يجب مراعاته لتصميم برنامج التربية الصحية؛ لتتمية الوعي الصحي لأطفال الروضة ذوي الإعاقة العقلية البسيطة، ومنها بعض الأدبيات والدراسات التي اهتمت ببرامج التربية الصحية للأطفال العاديين ومنها دراسة ويليام (2001) William، ، Walders ,et al, ومحمد السيد وآخرين (r . . r)، ودراسة والديرس وآخرين (2004) ودراسة تاراس وبوتس - داتيما ( Taras \& Potts-Datema 2005) ودراسة بيشوب

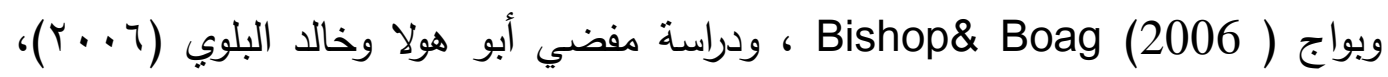

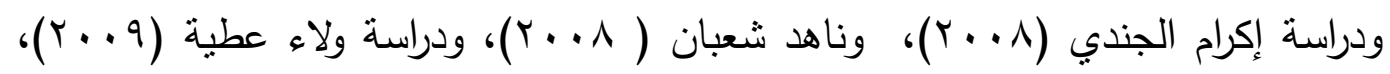

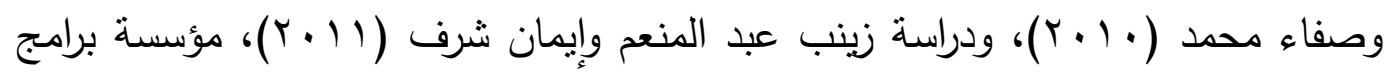

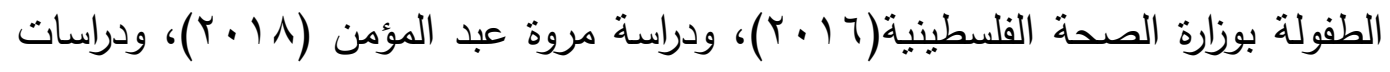
اهتمت ببرامج التربية الصحية للأطفال ذوي الاحتياجات الخاصة، ومنها دراسة ميكهيرجي وآخرين (Mukherjee ,et al,(2000) ، وليلى كرم الدين( ( . . ب)، ودراسة رقية العباس

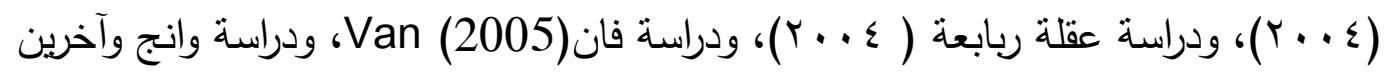
(Cooper,et al,2006) ، Wang,et al,(2006) ودراسة كوبر وآخرين ( وآخرين (Akker ,et al,(2006)، ودراسة ماهر صبري ومنى طرابية( V. . . . )، ودراسة

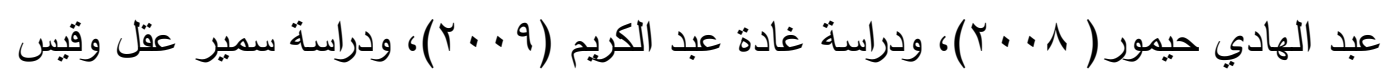

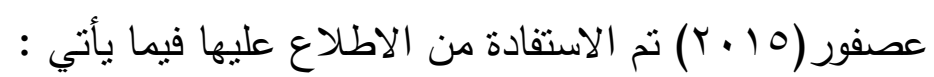
- - ضرورة تقديم برامج للتزبية الصحية للأطفال ذوي الإعاقة العقلية البسيطة في مرحلة الروضة، بطرق تتلاءم مع خصائصهم وسماتهم. - استغلال حب الأطفال، وميلهم للقصص وبناء البرنامج على شكل أنشطة قصصية تقدم للأطفال، وتوظيفها في إكساب هؤلاء الأطفال المعارف والاتجاهات والسلوك الصحي السليم. - يجب أن يكون كل طفل من أطفال الروضة ذوي الإعاقة العقلية البسيطة قادرًا على أداء السلوكيات الصحية المقدمة إليه بمفرده. 
- - يجب مراعاة البساطة والسهولة في البرنامج ليتناسب مع الأطفال. - توظيف شخصيات محببة للأطفال بالبرنامج لسهولة نوصيل المعلومات للأطفال، من خلال اختيار شخصيات القصص المحببة لديهم.

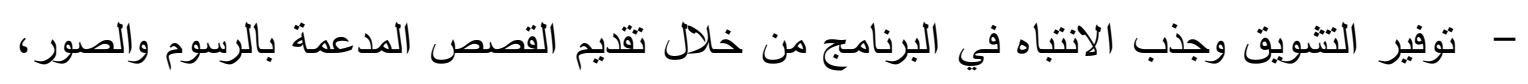

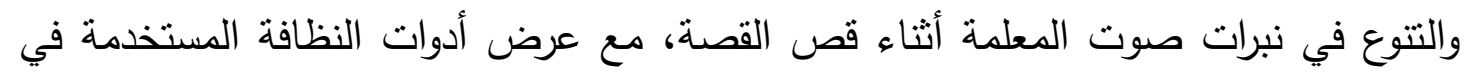
أحداث كل قصة.

- - يجب أن تكون البرامج المقدمة لهؤلاء الأطفال مرتبطة بحياتهم وبالبيئة التي يعيشون فيها، وفي

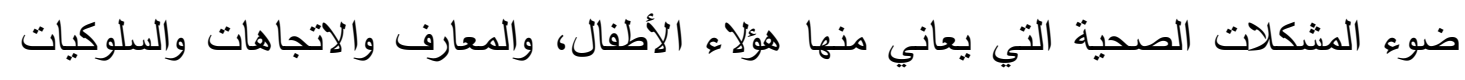

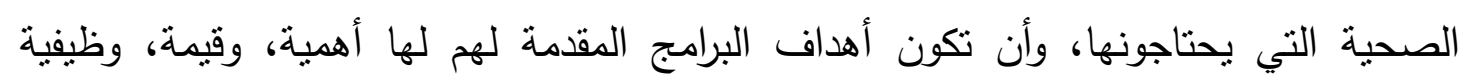

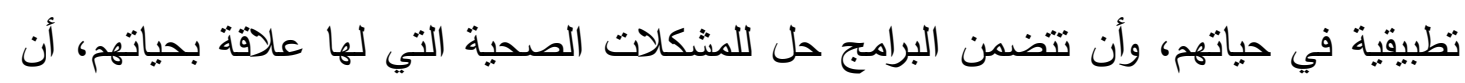
تتناسب مع استعداداتهم، واحتياجاتهم الثخصية، لتحد من مشكلاتهم الصحية التي يمرون بهان التها، وأن تتتاسب مع قدراتهم في اكتساب السلوكيات الصحية المقدمة لهم.

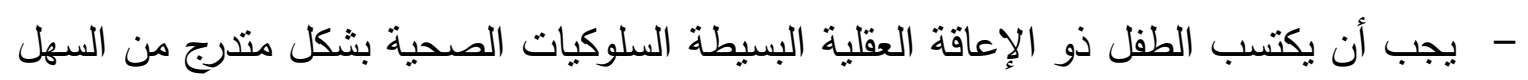

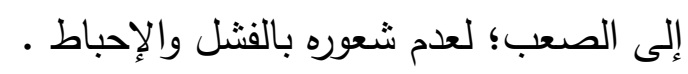
- - يتعلم أطفال الروضة ذوو الإعاقة العقلية البسيطة من خلال الحواس، فلابد من نوفير خبرات

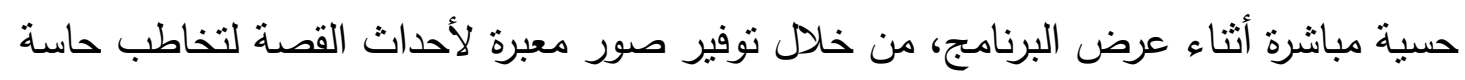

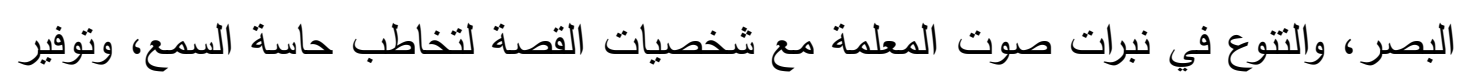
أدوات نظافة خاصة بكل طفل لتخاطب حاسة اللمس.

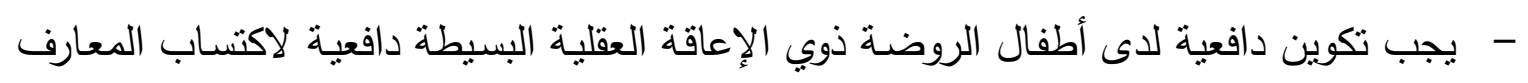

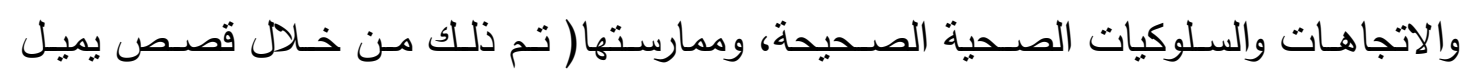
الأطفال إلى الاستماع إلبها؛ مما خلق الدافعية لديهم). - - ضرورة توفير في البرامج المقدمة للأطفال ذوي الإعاقة العقلية البسيطة ما يجذب لإنب انتباهم؛ لتسهيل عليهم عملية التعلم، وهذا ما يوفره برنامج الدراسة.

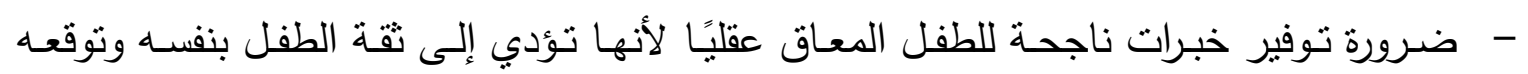

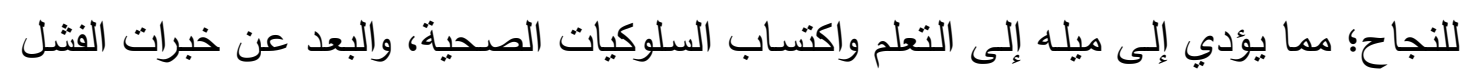
التي تؤدي إلى شعوره بالعجز والإحباط وعدم إقباله على التعلم.

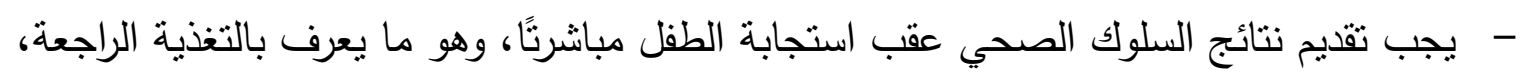

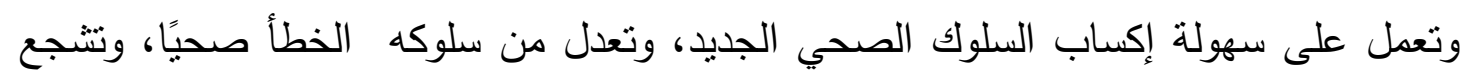

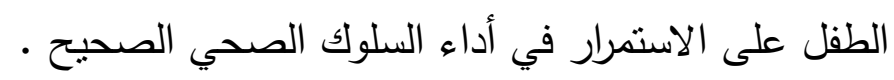


- ضرورة توفير التكرار الزائد لأداء السلوكيات الصحية مع أطفال الروضة ذوي الإعاقة العقلية

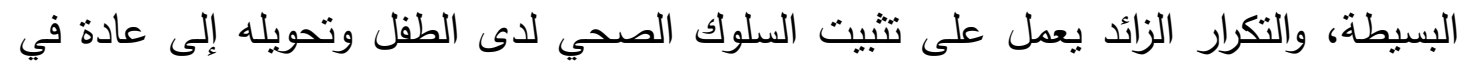

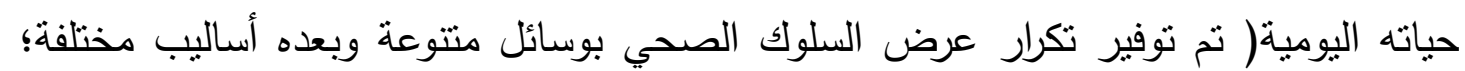

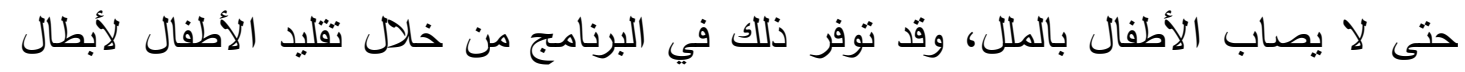
القصة في أداء السلوك الصحي، وتمثيل الأطفال لأحداث القصة مع تبادل الأدوار كل مرة).

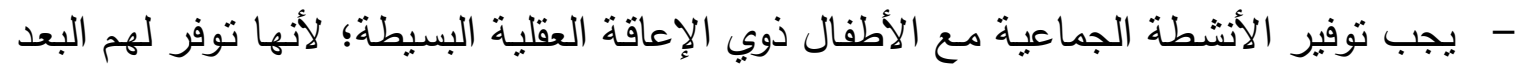

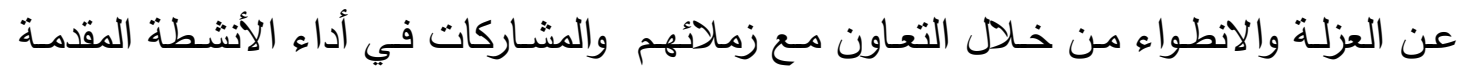
إليهم، ويؤكد كونني وآخرون Connie \&Bennett (2002:473) على أنه إذا تم تقديم برامج

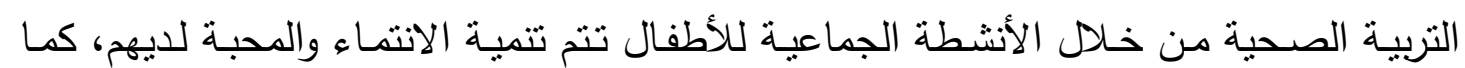
يتحقق تقبل الآخرين لهم عن طريق حرص الأطفال على نظافتهم الثخصية أثناء أداء الأنشطة

المختلفة، والتدريب على ممارسة سلوكيات النظافة، وبذللك يشعر كل طفل بالقيمة الذاتية.

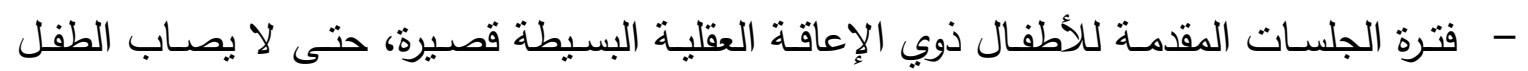

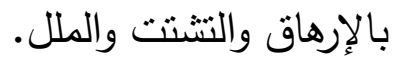
- - يجب تعميم ممارسة السلوك الصحي في المواقف المختلفة في حياتهم ، كما يجب تعميم ممارسة السلوك الصحي في الأماكن مختلفة. - - توفير مكان مناسب لتقديم البرنامج من خلال أحد الفصول البعيدة عن جميع المشتتات، على أن تكون جميع الجدران خالية من الملصقات واللوحات.

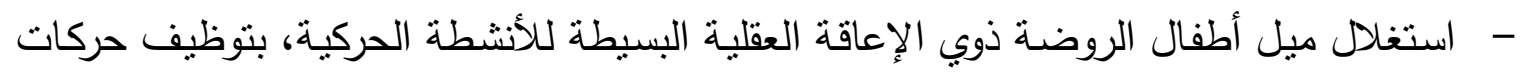

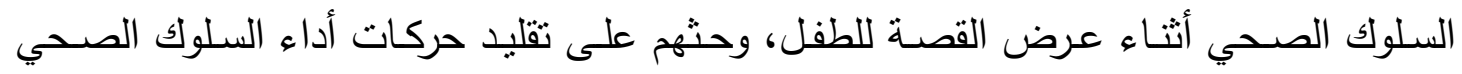
الموجودة بأحداث القصة، وحث كل طفل نحو تثنيل القصة مع تبادل الأدوار فيما بينهم.

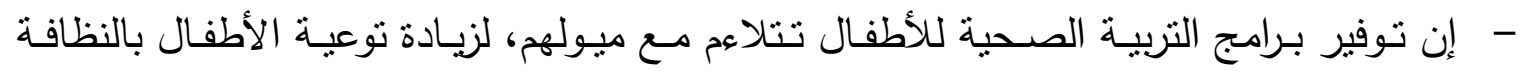

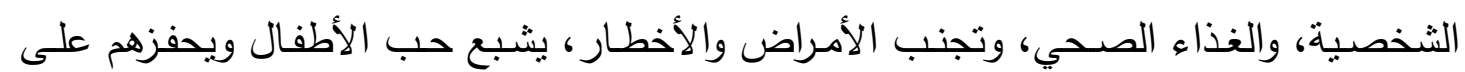

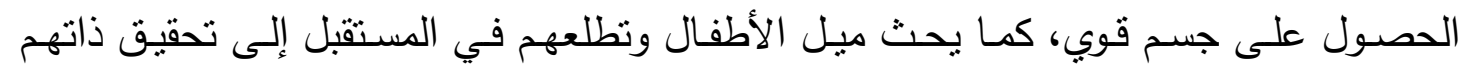

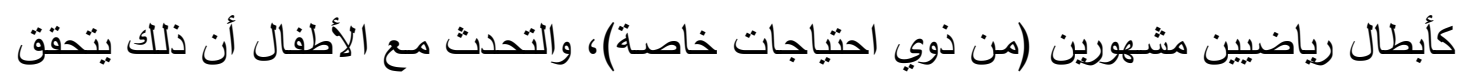

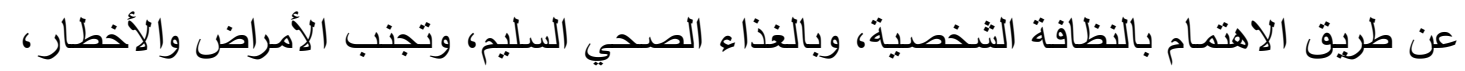

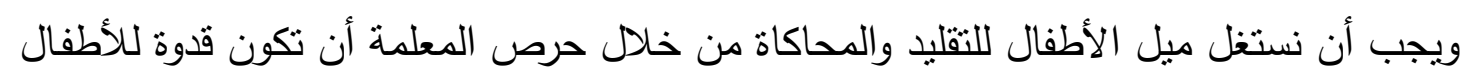

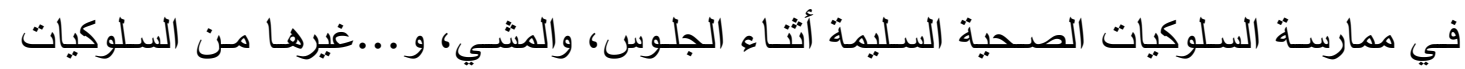
الصحية (Walker,2005:69) )، وتقديم السلوك الصحي من أبطال القصص المقدمة لهم. 
ب. بناء البرنامج القصصي في ضوء قائمة المعارف والاتجاهات والسلوكيات الصحية التي يحتاجها أطفال الروضة ذوي الإعاقة العقلية البسيطة من (0 إلى V ) سنوات لتنمية الوعي الصحي لايهم التي تم تحديدها.

ج. الاستفادة من الأدبيات والدراسات والبحوث السابقة التي تم عرضها في الإطار النظري للاراسة؛ لتحديد معايير تصميم القصص المستخدمة في برنامج التربية الصحية المقدم لأطفال الروضة ذوي الإعاقة العقلية البسيطة، ويتضح ذلك فيما يأتي:

ا ـ فكرة القصص المقدمة لأطفال الروضة ذوي الإعاقة العقلية البسيطة:

- - فكرة القصص من السلوكيات الصحية التي يحتاجها أطفال الروضة ذوي الإعاقة العقلية البسيطة( النظافة الثخصية، التغذية السليمة، الوقاية من الأمراض والمخاطر)؛ ولذلك فهي

$$
\text { لها قيمة في حياتهم. }
$$

- أن تكون فكرة كل قصة مستمدة من الخبرات الحياتية، والبيئة التي يعيشها الطفل. - - يجب أن تكون لكل قصة فكرة واحدة واضحة، ومحدة، وبسيطة، حتى يستطيع أن يفههها الطفل ذو الإعاقة العقلية، ويتجاوب معها.

تم مراعاة ذلك في إعداد البرنامج القصصي؛ حيث تكون البرنامج من (0) قصص، وهي (الحفلة مائدة الطعام - البطل - الأسنان الحلوة - الحديقة)، كل قصة تدور فكرتها حول فكرة واحدة ليسهل متابعتها من الطفل وفهمها.

\section{r. أحداث القصص المقدمة لأطفال الروضة ذوي الإعاقة العقلية البسيطة:}

- - أحداث القصص مستمدة من حياة الأطفال ذوي الإعاقة العقلية الواقعية(من خلال إكسابهم معارف ومعلومات صحية بسيطة، وتكوين اتجاهات نحو ممارسة السلوك الصحي لديهم، وتوظيف السلوكيات الصحية للأطفال في مواقف حياتية واقعية في حياته)، ومن الأحداث التي يمرون بها في حياتهم والمألوفة بالنسبة لهم ( تصميم أحداث القصص تتشابه مع حياة

$$
\text { الأطفال التي يعيشونها ومألوفة لهم). }
$$

- - يجب التسلسل المنطقي في أحداث القصص من بدايتها ثم العقدة ثم حلها. - - يجب أن تكون أحداث القصة شيقة، وجذابة. - - يغلب على أحداثها الفكاهة والمرح، لجذب الأطفال ذوي الإعاقة العقلية لأحداثها. - - تصميم نهايات سعيدة لكل القصص. - توفير أدوات نظافة خاصة مع كل قصة حسب أحداثها. - - أن تكون أحداث القصة قليلة ومترابطة؛ لتتناسب مع مستوى ذكاء الطفل، وعمره. - البعد عن الرمزية، والتجريد في أحداث القصة المقدة للأطفال ذوي الإعاقة العقلية البسيطة. 
تم مراعاة كل ذلك في تصميم أحداث القصص المقدمة في برنامج التربية الصحية المقدم لأطفال

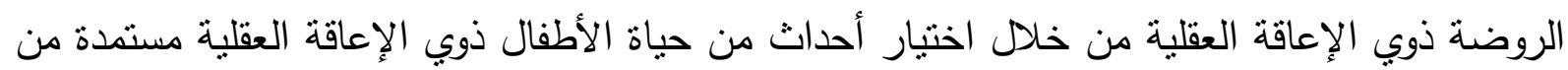

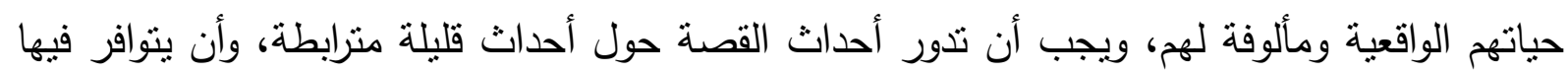

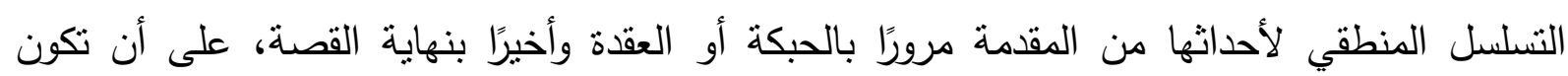

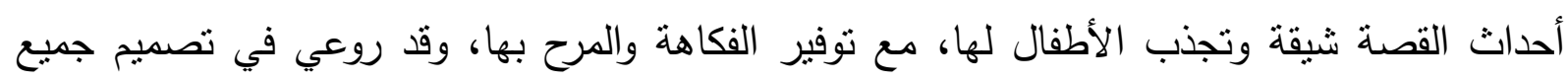
نهايات قصص البرنامج أن تكون سعيدة وعادلة. r. عقدة (حبكة) القصة المقدمة لأطفال الروضة ذان لكوي الإعاقة العقلية البسيطة: - أن تحتوى القصة على مقدمة بسيطة، يتم فيها التعارف على شخصيات القصة.

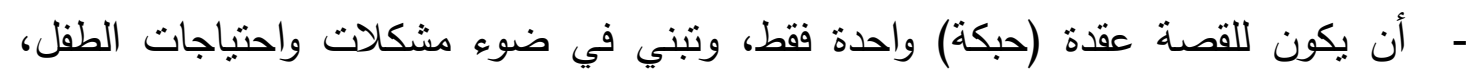
وتتميز بالبساطة. - حل عقدة القصة يكون متسلسلًا ومتتابعًا في نهاية القصة. - البعد عن القصص ذات العقد المركبة ومتتشابكة الأحداث. -

تم ذللك من خلال بناء كل قصة من قصص البرنامج في ضوء مشكلة واحدة فقط، تلبي احتياجات

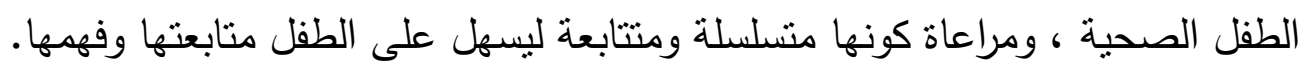
؛. شخصيات القصص المقدمة لأطفال الروضة ذوي الإعاقة العقلية البسيطة:

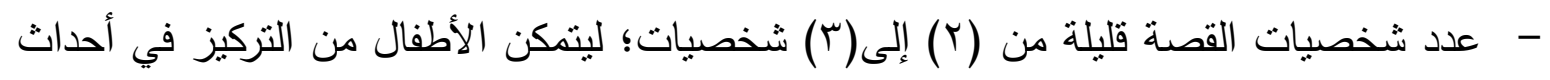
القصة ولسهولة منابعة كل شخصية.

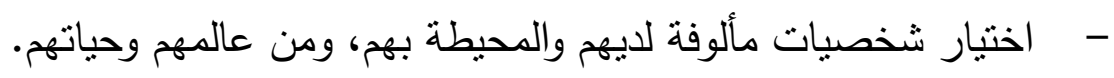
- أن تكون شخصيات القصة واضحة في تصرفاتها، ومقنعة. - أسماء الثخصيات من الأسماء المعروفة للأطفال، ومنتشرة والمألوفة لديهم، وإذا كان موجود دور مثلًا كدور الأم فتسمى أم في القصة أو جد يسمى جد في القصة وهكذا؛ ليسهل حفظها وحتى لا لاهل يشعر الطفل بالغربة تجاهها، ويجب البعد عن الأسماء الغريبة غير المألوفة للطفل أو الغريبة على مجتمعه.

تم مراعاة ذلك بتحديد (r) شخصيات لكل قصة من القصص المقدمة في البرنامج، وهي ( قصة

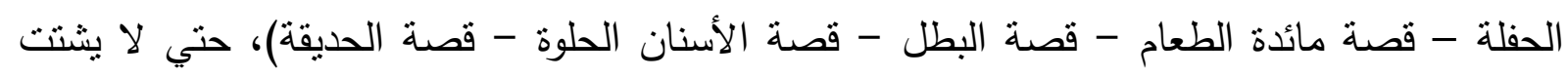

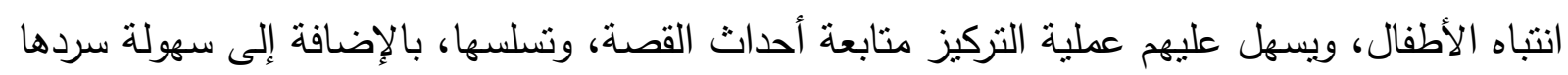

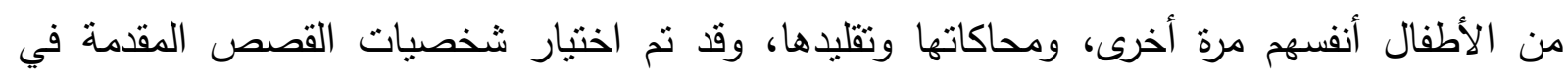


البرنامج من حياة الطفل، ومن الثخصيات التي يتعامل معها الطفل، وهي ثلاث من الثخصيات التالية

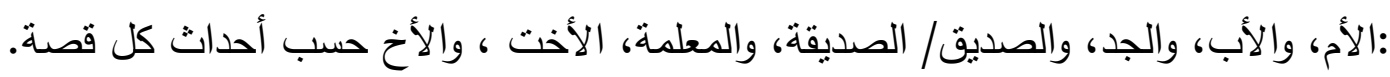
هـ لغة القصة المقدمة لأطفال الروضة ذوي الإعاقة العقلية البسيطة: - - يجب أن يتم استخدام العامية أثناء قص القصة عليهم، وعدم استخدام اللغة العربية الفصحى؛

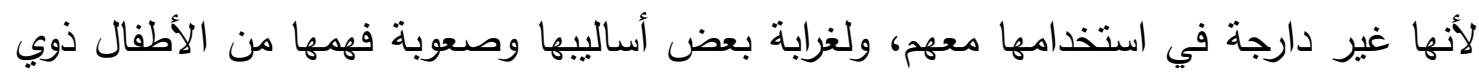

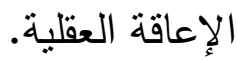
- - متخدام المفردات اللغوية المألوفة لهم والمعروفة . - أن يكون الحوار بين شخصيات القصة متميزًا بالإثارة والإمتاع لأحداثها. - - إذا كانت هناك أحد المفردات اللغوية الجديدة في القصة يتم شرحها لهم من خلال المفردات

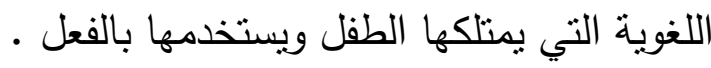
وقد تم مراعاة أن تعرض قصص البرنامج على الأطفال بالعامية حتي يسهل فهمها من الأطفال، واستخدام المفردات التي يستخدمونها باستمرار ، ويفهمونها.

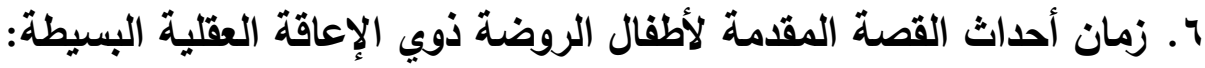

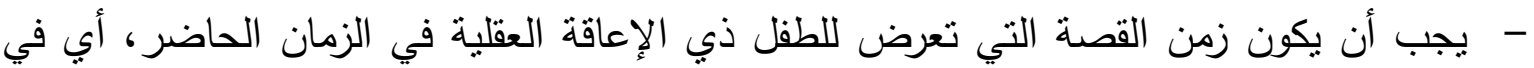
زمن الطفل نفسه الذي يعيش فيه. - - البعد عن استخدام أزمنة بعيدة في الماضي أو المستقبل ؛ لأن الطفل ذي الإعاقة العقلية غير قادر على استيعاب البعد الزمني في الماضي أو المستقبل وفهمه. - يجب أن يكون أحداث القصة في زمن واحد فقط.

تم مراعاة ذلك في أحداث القصة المرتبطة بزمن الحاضر الذي يعيش فيه الطفل، ولا يجب استخدام

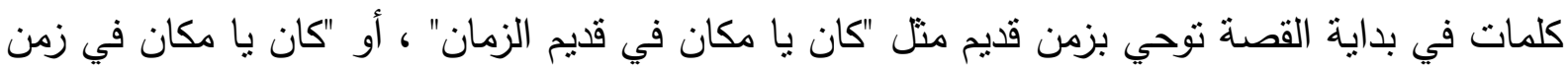

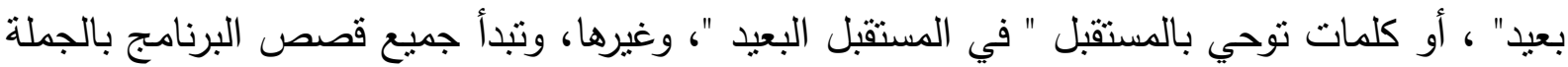

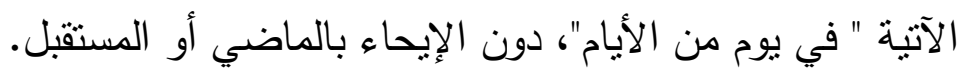

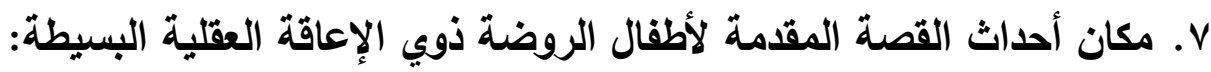
- - مكان أحداث القصة يكون مرتبط بحياة الطفل. - البعد عن الأماكن الغربية عنه، أو البعيدة؛ لصعوبة فهم الطفل ذي الإعاقة العقلية لذلك. تم مراعاة ذلك في القصص المقدة لأطفال الروضة ذوي الإعاقة العقلية البسيطة؛ حيث اتسمت أحداث كل قصة من قصص البرنامج بوحدة المكان، وهذا المكان قريب من حياة الطفل، قصة الحفلة

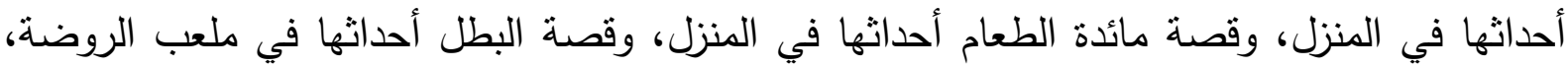
وقصة الأسنان الحلوة أحداثها في المنزل، وقصة الحديقة أحداثها في حديقة المدرسة. 
^. الثكل المادي للقصص المقدمة لأطفال الروضة ذوي الإعاقة العقلية البسيطة: - من حيث شكل القصة الخارجي: ثان تصميم القصص على اسكتشات من بطاقات الفوتوهول، أو اسكتشات من بطاقات

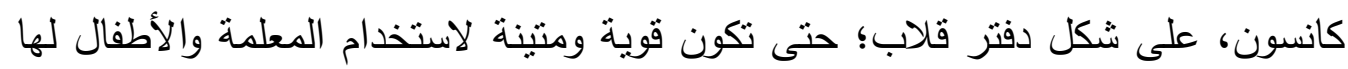
أكثر من مرة. ه غلاف كل قصة عليه صورة أو رسمة تعبر عن القصة، وتكون واضحة، وملونة، وكبيرة. هـ غلاف كل قصة يكتب عليه عنوانها بخط واضح وكبير وجميل، ويكتب بخط النسخ لأنه الخط الذي يتعلمه الطفل، والخط المنداول في الكتب والقصص والمجلات . بـ أن يكون حجم القصة مناسب ليستطيع حمله الطفل. - - من حيث الثكل الداخلي للقصة: خ ثم تصيم صور ورسوم لكل قصة معبرة عن أحداثها، وواضحة . هإز شخصيات القصة بتفاصيل محددة، وجذابة. ه استخدام ألوان زاهية في القصة، وواقعية، على ألا تبهت مع الاستعمال، وأن تكون ثابتة لا تلصق في يد الطفل والمعلمة في حالة إمساك أو لمس القصة.

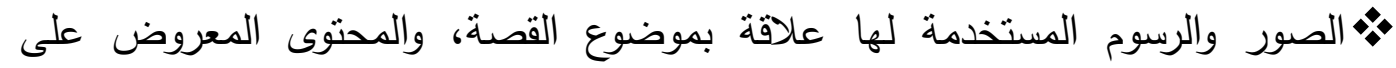

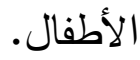
• أن تكون الصور والرسوم المستخدمة لها حجم مناسب بالنسبة للطفل؛ ليسهل عليه متابعتها والنظر إليها. • يجب أن نكون الصور والرسوم المستخدمة في كل قصة مناسبة لخصائص الطفل،

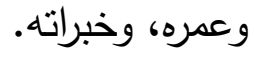
ثمت ثتلاعم الصور والرسوم المستخدمة في القصص مع الييئة المصرية.

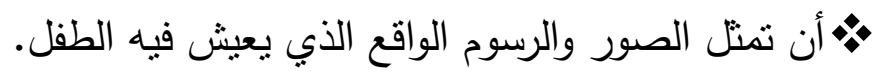

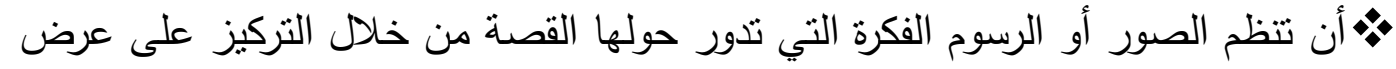
العناصر الرئيسة (شخصيات الصورة)، وتقليل عرض العناصر غير المهمة( تقليل تفاصيل خلفية الصورة) ؛ ليسهل على الطفل قراءة الصورة، وفهمها. د. يجب على المطلمة الالتزام ببعض التوجيهات قبل سرد القصة، وإثناءها، ويعدها المقدمة لأطفال الروضة ذوي الإعاقة العقلية البسيطة، وفيما يلي سوف يتم التم عرضها:

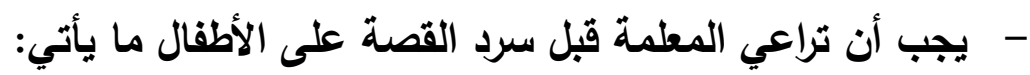


ثم إعداد المعلمة للمكان الذي سوف يتم فيه سرد القصة جيدًا، والتأكد من توافر الإضاءة، والتهوية الصحية، وأن ينوافر به منضدة على شكل نصف دائرة، ويوضع حولها (ع) كراسي. ثجهيز المعلمة للمكان ليتسنى للأطفال رؤية المعلمة بشكل واضح في حالة وقوفها أو جلوسها أثناء سردها للقصة على الأطفال. • تحديد الوسائل المناسبة لعرض القصة وتوفيرها، من صور ، ورسوم، أو وسائل، وأدوات التهاء نظافة أثثاء سرد القصة. ثمثرفير سهولة رؤية الأطفال للقصة المعروضة أمامهم، وسهولة رؤية أدوات النظافة التي سوف تنتخدمها المعلمة أثتاء عرض أحداث كل قصة من قصص البرنامج ، مثل: مشط، فرشاة شعر ....وغيرها من أدوات النظافة.

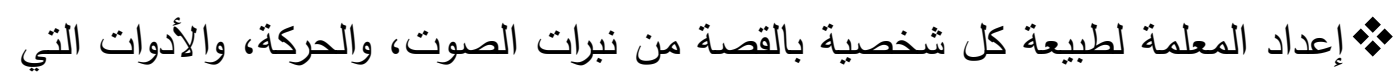
تحتاجها كل شخصية من شخصيات القصة لتنمية الوعي الصحي للأطفال. هب يجب على المعلمة أن تقرأ القصة أكثر من مرة قبل سرد القصة على الأطفال، وتدرب نفسها على سردها أكثر من مرة، لتصبح متمكنة في عرضها على الأطفال بطريقة

$$
\text { مشوقة وجذابة. }
$$

- - يجب أن تراعي المعلمة أثناء سرد القصة على الأطفال ما يأتي: ثرص المعلمة على التواصل البصري الدائم والمباشر بينها وبين كل طفل من الأطفال بالجلسة. ثم أن لا تسرع المعلمة أثناء سرد القصة حتى لا يسنطيع الأطفال متابعة أحداث القصة، أو تبطئ حتي لا يشعر الأطفال بالملل.

ثمان تسرد المعلمة القصة بطريقة فكاهية وممتعة ؛ لجذب انتباه الأطفال لأحداثها. ثمب أن تمهد المعلمة للقصة وتثير انتباه الأطفال للاستماع لها، ويمكنها تحقيق ذلك من خلال تحدثها مع الأطفال حول الفكرة العامة الرئيسة للقصة، أو بالتحدث عن الثخصية الأساسية للقصة. هلى المعلمة أن توظف تعبيرات وجهها، وحركات يدها، وحركات جسمها، والجلوس والوقوف، ونبرات صوتها أثناء سرد القصة. ثلى المعلمة أثتاء سرد القصة التتوع في نبرات الصوت حسب الموقف وأحداث القصة، كما عليها عمل نبرة صوتية خاصة بكل شخصية من الشخصيات الموجودة في القصة. * تطلب المعلمة دن الأطفال تقليدها أثناء أدائها للحركات المعبرة عن السلوك الصحي لأداء بعض الثخصيات بالقصة، منل (تمشيط الشعر). 
ثمرص المعلمة على أن يكون صوتها أثناء سرد القصة واضحًا ومعبرًا، ويسمعه جميع الأطفال في الجلسة. ثوفر المعلمة الأدوات والوسائل الخاصة بالسلوكيات الصحية، واستخدامها أثناء سرد القصة على الأطفال بالتزامن مع أداء شخصيات القصة في أحداثها، كمحاكاة لشخصيات القصة. ثمب يجن أن تتجنب المعلمة أثناء سرد القصة أسباب التشتت كوجود ضوضاء، أو استخدام صور ، أو وسائل، أو أدوات غير مرتبطة بموضوع القصة. ثوفير الحركة والنشاط للطفل أثثاء سرد القصة، من خلال تقليد حركات الثخصيات

$$
\text { القصة في أداء السلوك الصحي. }
$$

\section{- - يجب أن تراعي المعلمة بعد سرد القصة على الأطفال، ما يأتي:}

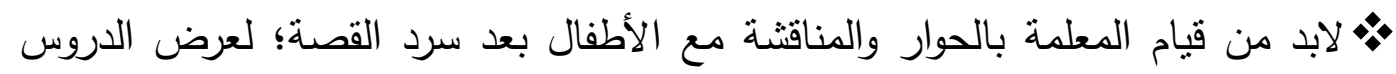
المستفادة من القصة، والأفكار المهمة التي تدور حولها القصة، ولهذه المناقثات دور كبير لهؤلاء الأطفال؛ لإتاحة الفرصة للطفل للتعبير عن نفسه؛ مما ينعكس عليه في زيادة تقديره لذاته، وثقته في نفسه، وخروجه من عزلته وخجله .

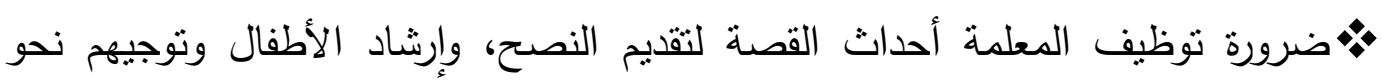
ممارسة السلوك الصحي. *مليل عناصر القصة، وأهدافها، ومضمونها مع الأطفال. •طلب المعلمة من كل طفل من الأطفال أن يعيد سرد أحداث القصة مع محاكاة حركات السلوك الصحي. • ثلاب المعلمة من كل طفل وضع عنوان آخر للقصة، ونهاية أخرى؛ مما يساعد الطفل على تتمية المهارات اللغوية. •طلب المعلمة من الأطفال تمثيل أحداث القصة، وتبادل أدوار الشخصيات الموجودة في القصة. ثطلب المعلمة من كل طفل من الأطفال ذكر المواقف أو الأحداث التي أعجبته في القصة. 
r-r- مرحلة الإنتاج: إنتاج مصادر التعلم المقدة للمجموعة التجريبية التي درست من خلال

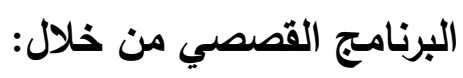

- - إنتاج القصص المقدة في البرنامج على شكل اسكتثات من بطاقات الفوتوهول، أو اسكتشات من بطاقات كانسون، على شكل دفتر قلاب؛ حتى تكون قوية ومنينة لاستخدام

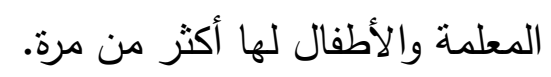

- رسم الصور والرسوم المستخدمة في القصص بألوان زاهية ، وواقعية ، وثابتة. - - توفير الأدوات الآتية لكل طفل من أطفال المجموعة التجريبية:

مشط وفرشاة للشعر ، ومعجون أسنان وفرش أسنان، مبرد أظافر خشب، فوطة، مرايات صغيرة،

طبق وملعقة وشوكة بلاستيك، صابون صلب، وصابون سائل ، شامبو للشعر ، مناديل ورق.

ץ- - - مرحلة التحكيم والتجريب: للتحقق من صلاحية البرنامج القصصي للتطبيق على أطفال الروضة

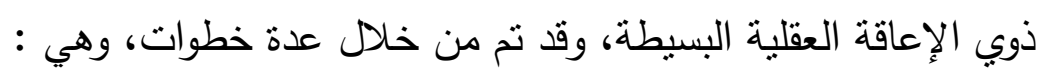

ץ- צ- 1 - عرض البرنامج على عدد من المحكين والخبراء المتخصصين للاستفادة من خبراتهم في البرنامج، وتخصصاتهم في المجالات الآتية: - - برامج الأطفال ذوي الاحتباجات الخاصة.

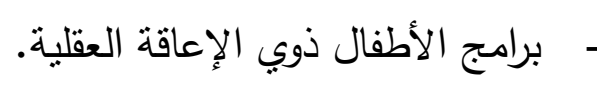

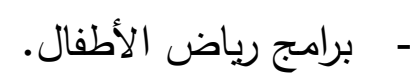

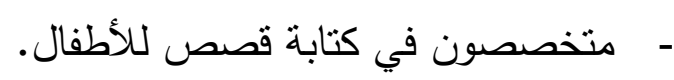

- - الخدمات الصحية للأطفال ذوي الإعاقة العقلية، وأطباء أطفال، وممرضات في مراكز

الصحة المتخصصة في التعامل مع الأطفال.

-

من خلال عرض البرنامج عليهم، مرفقًا باستمارة استطلاع رأي لكل محكم لإبداء ألئه أليه فيما يأني:

مدى ملائمة البرنامج للهيف المصنم من من أجله.

مدى ملائمة البرنامج لأطفال الروضة ذوي لإندي الإعاقة العقلية البسيطة.

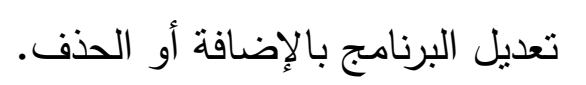

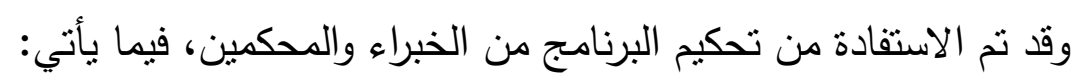

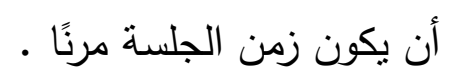

بيدأ البرنامج بمهارات النظافة الثخصية المناسبة لهم، ومنها ( تمشيط الثعر ، غسل الوجه ،

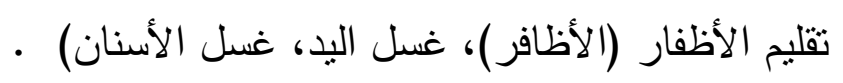


قبل تقديم قصة جديدة للأطفال، يجب النأكد من اكتساب كل طفل وإتقانه لجميع المعارف والسلوكيات الصحية في القصة التي قدمت له.

ضرورة نوفير وقت للمناقثة مع الأطفال لمناقثة الدروس المتتفادة بعد الانتهاء من كل قصة. ه اختصار أسماء بعد قصص البرنامج منل قصة (حفلة عيد الميلاد)، ويتم اختصار اسمها لقصة ( الحفلة)، واختصار اسم قصة (البطل المشهور ) إلى (البطل)، واختصار اسم قصة (الذهاب إلى لى الحديقة) إلى (الحديقة) ؛ ليسهل على الأطفال حفظ أسماء القصص، وترديدها بسهوله ويسر. r-צ-r- - تجريب البرنامج على عينة استطلاعية من أطفال الروضة ذوي الإعاقة العقلية

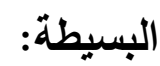
جرب البرنامج على عينة استطلاعية من أطفال الروضة ذوي الإعاقة العقلية البسيطة، بلغ عددهم

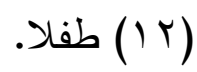

وقد تم الاستفادة من أخذ آراء الخبراء والمتخصصين والمحكمين في البرنامج، وتجريب البرنامج على العينة الاستطلاعية بما يأتي:

ضرورة عمل مقابلة لأسرة كل طفل من الأطفال الذين سوف يتم تطبيق البرنامج عليهم،

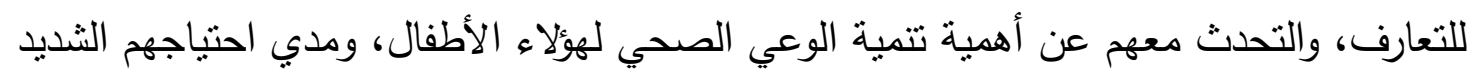

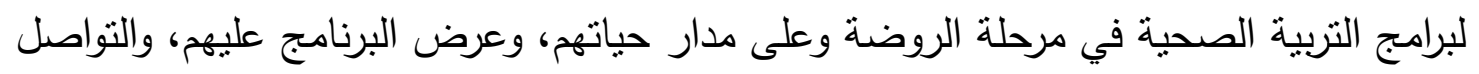

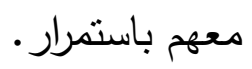
يجب نوفير أدوات نظافة خاصة بكل طفل، وبكل قصة مقدمة، لتوظيفها أثناء أحداث القصة؛

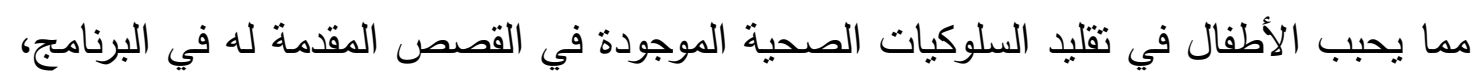
كما بساعد على إتقان الطفل لممارسة السلوك الصحي وميله لأدائه.

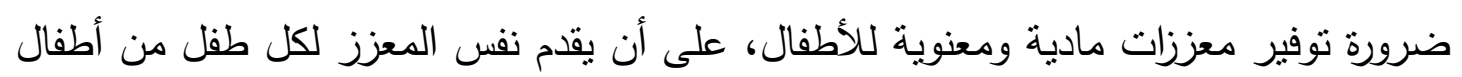
الجلسة الواحدة؛ حتي لا يشعر الطفل بالغيرة من زملائه. هجب أن يقدم البرنامج بترتيب القصص الآثية، وهي(قصة الحفلة - قصة مائدة الطعام- قصنة البطل - قصة الأسنان الحلوة- قصة الحديقة).

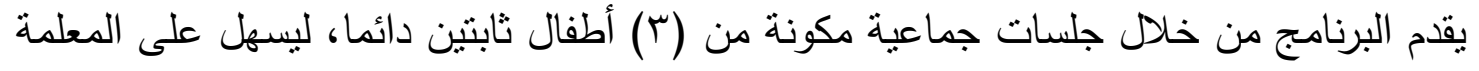

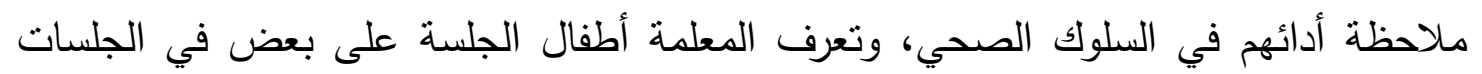
الأولى كل مرة حتى يسهل عليهم التعاون مع بعضهم، ثم بعد ذلك ترحب بهر بهم بأسمائهم وتطلب منهم أن يسلموا ويرحبوا ببعضهم. 


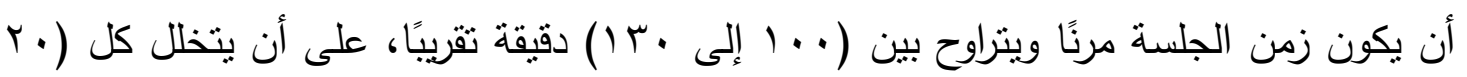

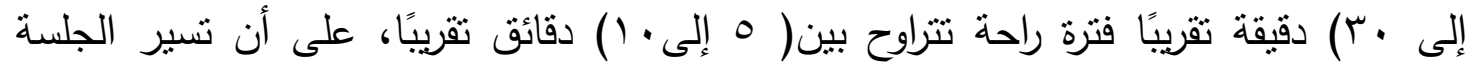

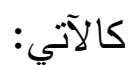

( • (1) دقائق تقرييًا ترحيب بالأطفال، وتعرفهم علي بعض في الجلسة الأولى، ويتم

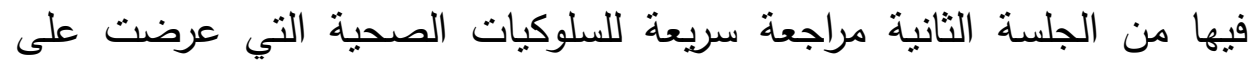
الأطفال في الجلسات السابقة، وتمهيد للقصة التي سوف تعرض علئه عليهم في الجلسة

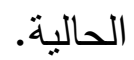

• (ץ) دقيقة تقريبًا قص القصة على الأطفال، مع تتفيذ المعلمة حركات السلوك

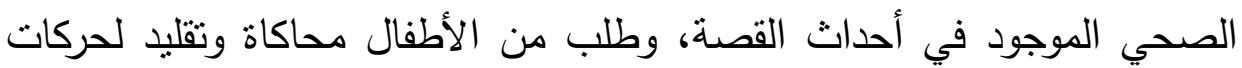
السلوك الصحي المقدم من خلال أحداث القصة، بالاستعانة بالأدوات النظافة الخاصة بأحداث القصة لكل طفل. • من ( ه إلى • (1) دقائق تقريبًا راحة يسمح خلالها للأطفال بتلبية احتباجاتهم من

$$
\text { شرب أو تتاول الطعام أو ذهاب إلى الحمام. }
$$

(0) دقيقة تقريبًا مقسمة إلى (0) دقائق لكل طفل من (T) أطفال من مجموعة إنا الجلسة الواحدة، يجلس بجوار المعلمة ويحكي فيها الطفل أحداث القصة بمساعدة

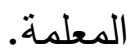

ه ( إلى · ( ) دقائق نقريبًا راحة يسمح بها للأطفال بالمثل كالفترة السابقة لتلبية

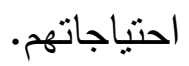

ه (ץ) دقيقة تقريبًا يمتل أطفال الجلسة الواحدة وعددهم (r) أطفال أحداث القصة خلالها ثلاث مرات كل مرة (·) دقائق تقريبًا، ويتبادل فيها الأطفال الأدوار

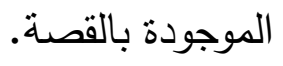

• (0 إلى · (1) دقائق راحة يسمح بها للأطفال بالمتل كالفترة السابقة لتلبية

$$
\text { احتياجاتهم. }
$$

( • (1) دقائق تقرييًا مناقثة أخيرة مع الأطفال عن الدروس المستفادة من القصة،

$$
\text { والسماح لكل طفل بالحديث. }
$$

هبب أن نطلب المعلمة من كل طفل على حده تقليد كل سلوك صحي من السلوكيات التي تحتويها أحداث كل قصة، ليسهل عليها ملاحظة ومراقبة كل طفل أثناء أداء كل سلوك. بعد التأكد من أداء السلوك الصحي لكل طفل على حده، تطلب المعلمة من أطفال الجلسة تقليد

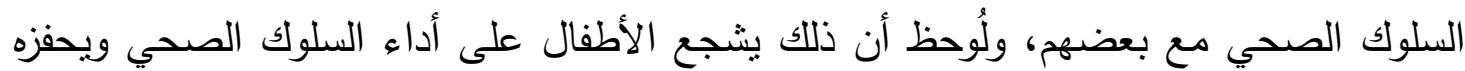
لايهم، كما يضيف جوًا من المتعة والألفة بين الأطفال. 
يجب تهيئة مكان عرض القصص المقدة لأطفال الروضة ذوي الإعاقة العقلية البسيطة، ويتم ذلك بما يأني:

• اختيار مكان بعيد عن المشتات السمعية كالضوضاء، ولا يوجد به المشتتات

$$
\text { البصرية كلوحات على الحائط داخل غرفة النشاط. }
$$

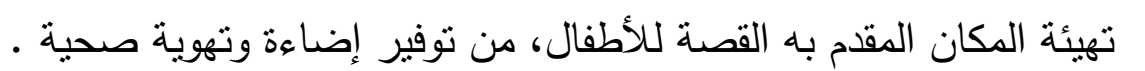

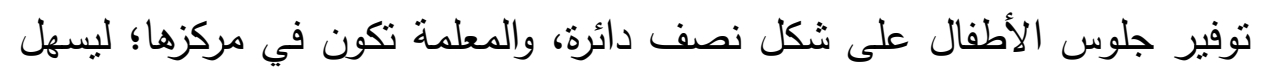

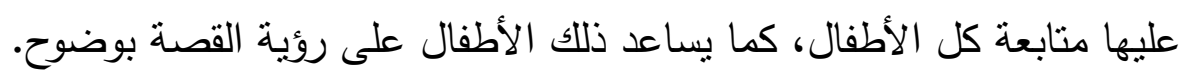
تم تهيئة المكان الذي سوف تحكى فيه القصص لأطفال الروضة ذوي الإعاقة العقلية البسيطة من

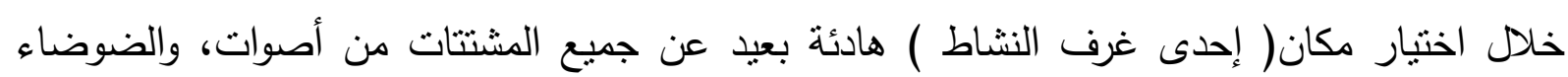
ووضع بها منضدة على شكل نص دائرة صغيرة وأربع كراسي صغيرة.

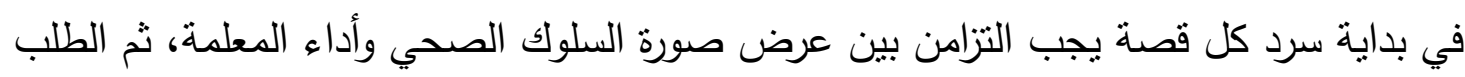

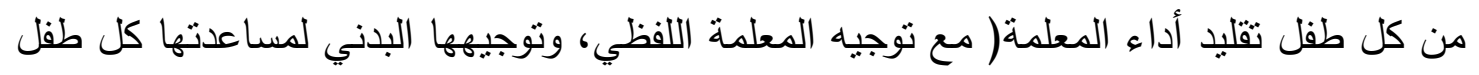

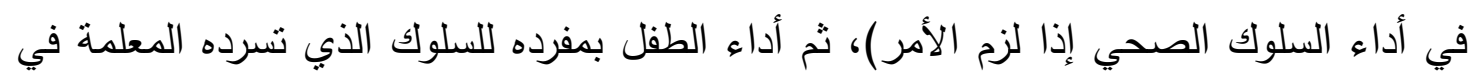
القصة ( بدون توجيه من المعلمة). يجب مقارنة أداء الطفل بنفسه، ولا يجب مقارنة المعلة أدائه بزملائه.

في ضوء الاستفادة من آراء المحكمين والخبراء، ومن التجريب على العينة الاستطلاعية لأطفال

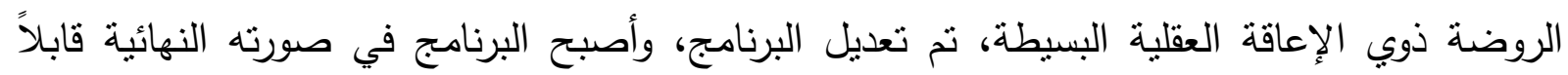

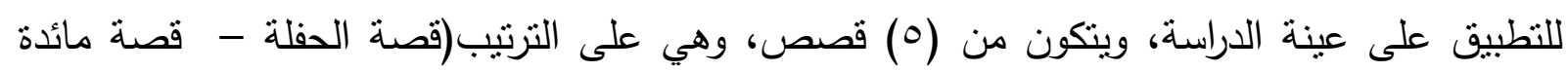
الطعام - قصة البطل -قصة الأسنان الحلوة - قصة الحديقة). بإعداد البرنامج القصصي لتتمية الوعي الصحي لأطفال الروضة ذوبي الإعاقة العقلية البسيطة، تم

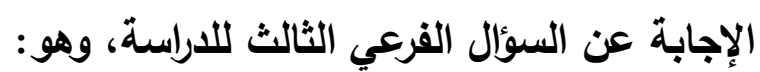
ما البرنامج القصصي لتنمية الوعي الصحي لاى أطفال الروضة ذوي الإعاقة العقلية البسيطة؟

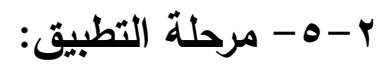
بلغ عدد أطفال عينة الدراسة (؟ Y) طفلا ممن تتطبق عليهم جميع شروط اختيار العينة من أطفال الروضة ذوي الإعاقة العقلية البسيطة في المستوى الثاني من روضات التربية الفكرية بروضات (الرمل المبري، وأحمد شوقي) بمحافظة الإسكندرية، وتم تقسيمهم على مجموعتين: أحدهما المجموعة التجريبية

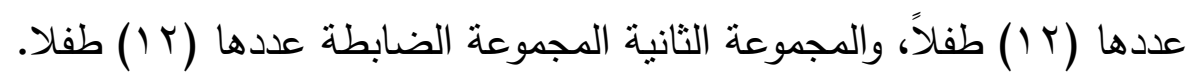


تم تطبيق البرنامج القصصي على أطفال المجموعة التجريبية، في الفصل الدراسي الأول من العام

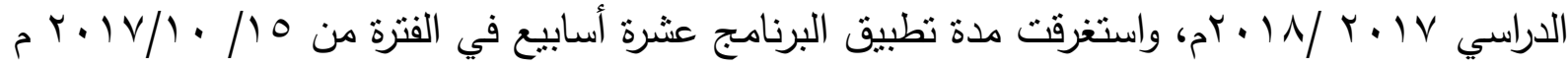

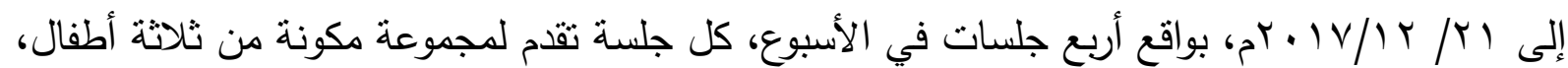

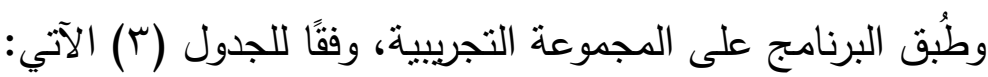
جلول (r) يوضح مدة تطبيق البزنامج القصصي لتنمية الوعي الصحي لأطفال الروضة ذوي الإعاقة العقلية

\begin{tabular}{|c|c|c|}
\hline عدد الجلسات & القصة & الأسبوع \\
\hline أربع جلسات في الأسبوع كل جلسة تقدم لمجموعة & الحفلة & الأول \\
\hline أربع جلسات في الأسبوع كل جلسة تقدم لمجموعة & الحفلة & الثناني \\
\hline أربع جلسات في الأسبوع كل جلسة تقدم لمجموعة & مائدة الطعام & الثالث \\
\hline أربع جلسات في الأسبوع كل جلسة تقدم لمجموعة & مائدة الطعام & الرابع \\
\hline أربع جلسات في الأسبوع كل جلسة تقدم لمجموعة & البطل & الخامس \\
\hline أربع جلسات في الأسبوع كل جلسة تقدم لمجموعة & البطل & السادس \\
\hline أربع جلسات في الأسبوع كل جلسة تقدم لمجموعة & الأسنان الحلوة & السابع \\
\hline أربع جلسات في الأسبوع كل جلسة تقدم لمجموعة & الأسنان الحلوة & الثامن \\
\hline أربع جلسات في الأسبوع كل جلسة تقدم لمجموعة & الحديقة & التاسع \\
\hline أربع جلسات في الأسبوع كل جلسة تقدم لمجموعة & الحديقة & العاشر \\
\hline
\end{tabular}

ويتضح من جدول رقم (ץ) توزيع البرنامج القصصي الذي طبق على أطفال المجموعة التجريبية. 
ץ- - - مرحلة التقويم ويقصد بها التطبيق البعدي والتتبعي:

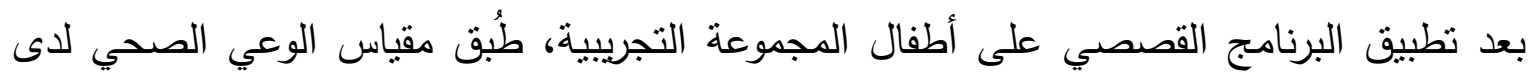

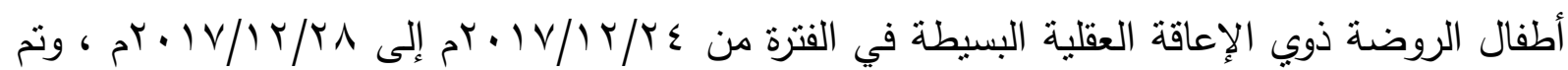

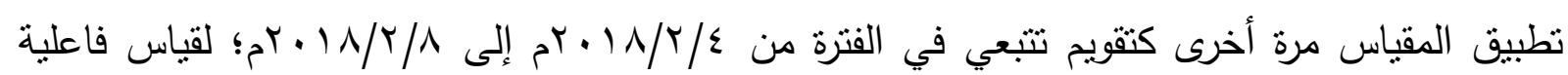
البرنامج القصصي لتنمية الوعي الصحي لأطفال الروضة ذوي الإعاقة العقلية البسيطة. ثالثاً: الأدوات المستخدمة في هذه الدراسة هي:

ا. اختبار ستانفورد بينيه الصورة الخامسة ترجمة صفوت فرج (1) (1)، ولاختيار الأطفال ذوبي

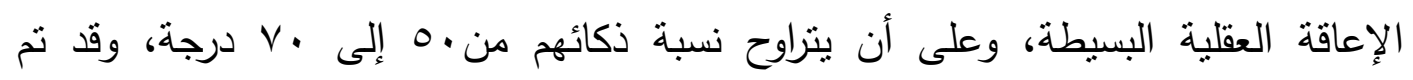

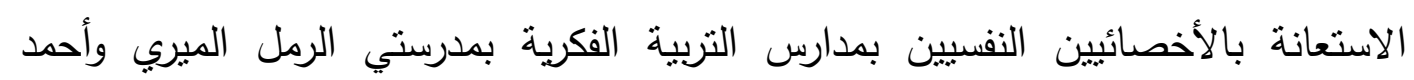

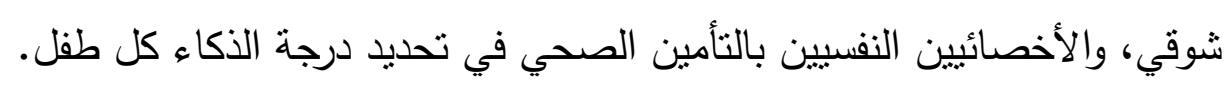

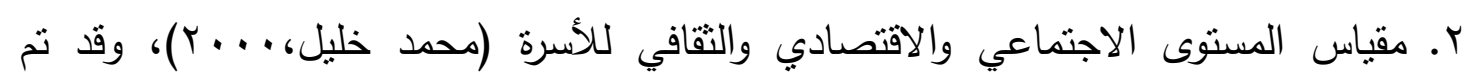

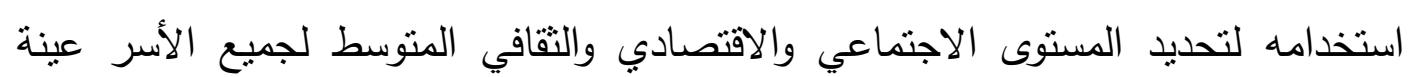
الدراسة للتأكد من تكافؤ الأسر أطفال عينة الدراسة في ذلك.

r. مقياس الوعي الصحي لدى أطفال الروضة ذوي الإعاقة العقلية البسيطة (إعداد الباحثة). ع. البرنامج القصصي (إعداد الباحثة).

وفيما يأتي عرض خطوات إعداد مقياس الوعي الصحي لاى أطفال الروضة ذوي الإعاقة العقلية

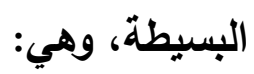

\section{r-}

يهدف المقياس إلى تحديد مستوى الوعي الصحي لأطفال الروضة ذوبي الإعاقة العقلية البسيطة. r-r - r- إعداد الصورة الأولية للمقياس:

للتوصل إلى صياغة عبارات المقياس في صورته الأولية، اتبعت الإجراءات الآتية: - مراجعة بعض الأدبيات والدراسات والبحوث السابقة الدتعلقة بالوعي الصحي لأطفال الروضة، والأطفال ذوي الاحتياجات الخاصة. بعض الاديات ولات

- ملاحظة سلوكيات أطفال الروضة ذوي الإعاقة العقلية البسيطة الصحية في المواقف الحياتية المختلفة. - لقاءات متعددة مع خبراء في مجال التربية الخاصة، ومجال التربية الصحية، ومناهج وبرامج الطفولة،

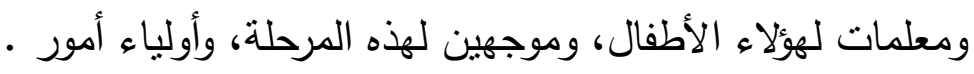


- ـ الاطلاع على عدد من مقاييس واختبارات الوعي الصحي المقدمة لأطفال الروضة، وللأطفال ذوي الاحتياجات الخاصة، ومنها ما يأني:

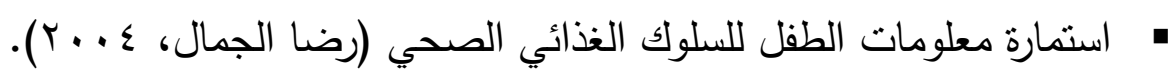

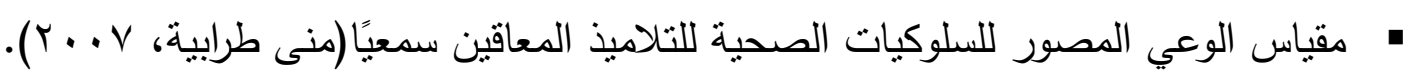

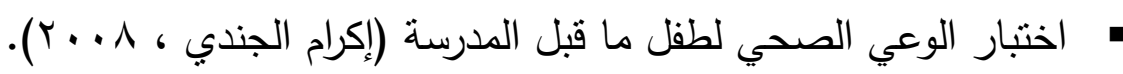

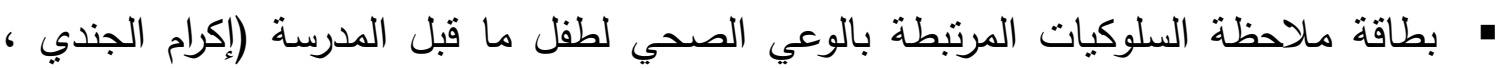

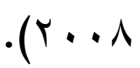

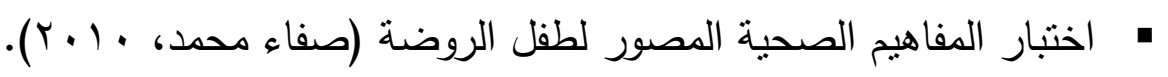

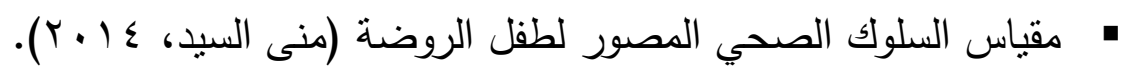

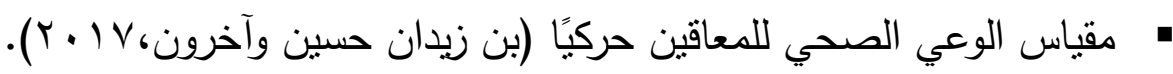

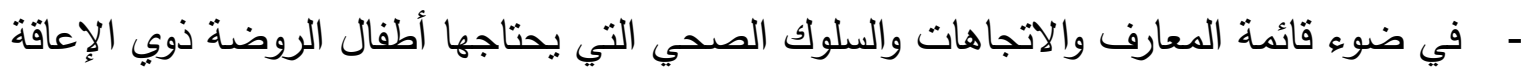
العقلية البسيطة التي نم الحصول عليها. في ضوء ما سبق تم صياغة عبارات المقياس، وقد روعي عند صياغة عبارات المقياس عددًا من المعايير ، ونوجزها فيما يأتي: • أن تكون كل عبارة قصيرة، وتدور حول فكرة واحدة.

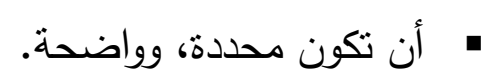

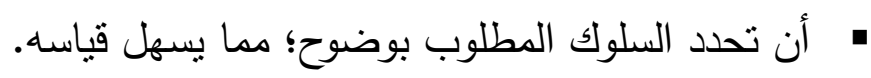

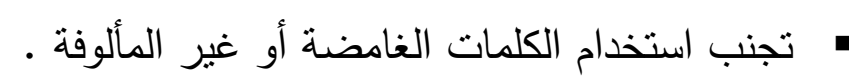
ه البعد عن العبارة التي يمكن تفسيرها بأكثر من طريقة.

اشتمل المقياس في صورته الأولية على تعليمات توضح لولي أمر طفل الروضة ذي الإعاقة العقلية

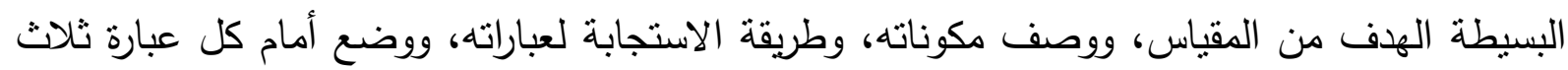

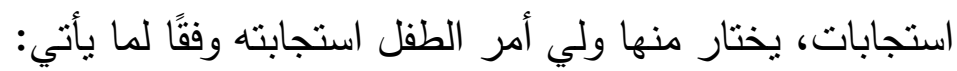
- إذا كانت العبارة تتطبق تمائًا على طفلك ضع علامة تحت (دائمًا) .

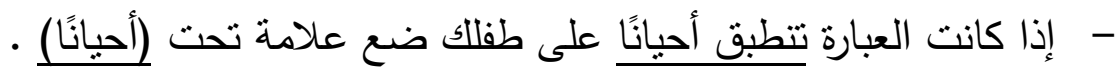
- إذا كانت العبارة لا تتطبق على طفللك ضع علامة تحت (مطلقًا) . 


\begin{tabular}{|c|c|c|c|}
\hline مطلقًا & 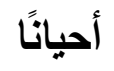 & دائمًا & 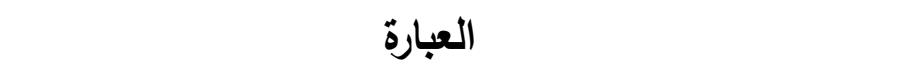 \\
\hline & & $\checkmark$ & إذا كانت العبارة تتطبق تمامًا على طفللك ضع علامة تحت \\
\hline & $\sqrt{ }$ & & إذا كانت العبارة تتطيق أحيانًا على طفلك ضع علامة تحت \\
\hline$\checkmark$ & & & إذا كانت العبارة لا تنطبق على طفلك ضع علامة تحت \\
\hline
\end{tabular}

وقد تكون المقياس في صورته الأولية من ثلاثة أبعاد(VT) عبارة، وهي: - البعد الأول : النظافة الثخصية ، ويتكون من(Y) عبارة. - البعد الثاني: التغذية السليمة، ويتكون من (rr) عبارة. - البعد الثالث: الوقاية من الأمراض والمخاطر ، ويتكون من (ro)عبارة. ويوفر لكل ولي أمر مقياسًا خاصًا للاستجابة به، ويجاب على المقياس من قبل أحد الوالدين، من خلال قراءة كل عبارة من عبارات المقياس على حده، ويحدد مدي انطباقها على طفله. r-r- وضع نظام تصحيح مقياس: وضعت ثلاثة اختبارات للاستجابة على كل عبارة من عبارات

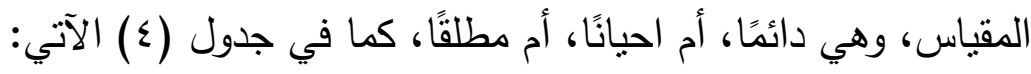

\begin{tabular}{|c|c|c|c|}
\hline مطلقًا & أحيانًا & دائمًا & العبارات \\
\hline صفر & 1 & r & عبارة \\
\hline
\end{tabular}

r- - - التحقق من صدق المقياس: للتحقق من صدق محتوى المقياس تم من خلال ما يأتي: ب-؟-1- صدق المحكمين: عُرض المقياس في صورته الأولية على عدد من المحكمين

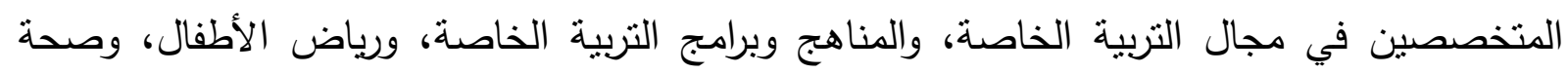

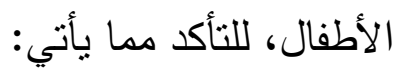

مدى وضوح الصياغة اللغوية لكل عبارة، وصحتها. مدى مناسبة كل عبارة للهدف منها. هدى صلاحية أبعاد المقياس. هدى صلاحية العبارات لكل بعد من أبعاد المقياس. مدى صلاحية كل بعد من أبعاد المقياس. اقتراحات كل محكم (إضافة أو حذف) عبارات.

وقد أبدى المحكمون مجموعة من الملاحظات، يمكن تلخيصها فيما يلي: 


$$
\begin{aligned}
& \text { - - - مذف عبارتين لتكرارهما في عبارات أخرى. } \\
& \text { - تعديل بعض العبارات بإعادة صياغتها لتكون أكثر وضوريًا. } \\
& \text { - ترتيب عبارات المقياس بطريقة عشوائية . } \\
& \text { - أن يتم عرض تعليمات المقياس على ولي أمر الطفل قبل الاستجابة. }
\end{aligned}
$$

كما نم الاحتفاظ بالعبارات التي كانت فيها نسبة اتفاق المحكمين عليها ـو\% و فأكثر ، وأُلغيت

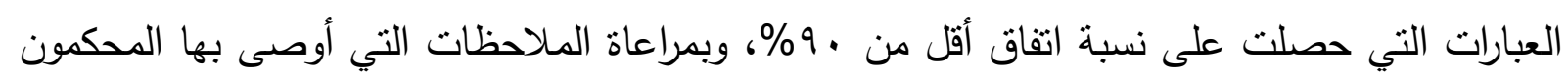

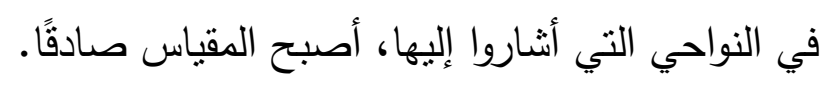

r- צ- - - الصدق الداخلي: نم التحقق من الصدق الداخلي للاختبار من خلال تطبيقه على عينة

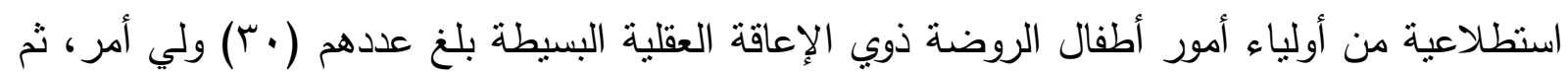

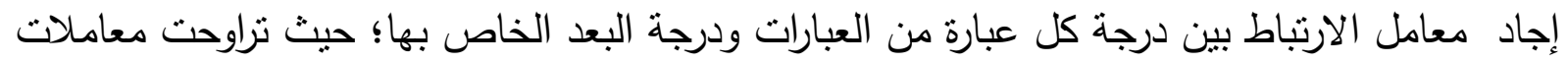

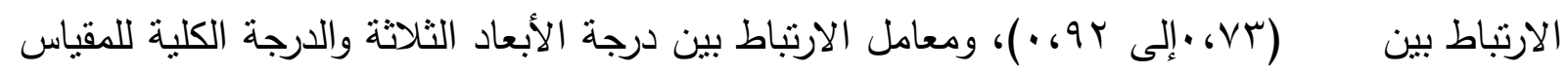

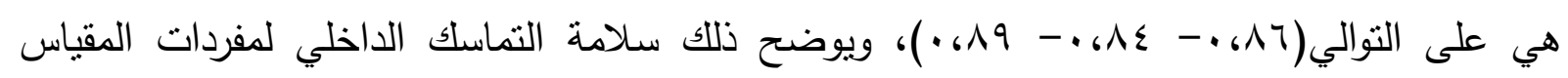

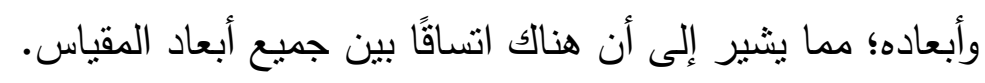
r-ه- حساب ثبات المقياس: بعد التحقق من صدق المحكمين للمقياس، طُبق على عينة

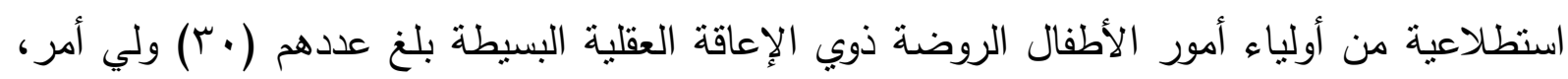

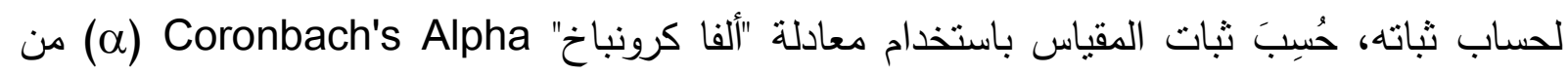

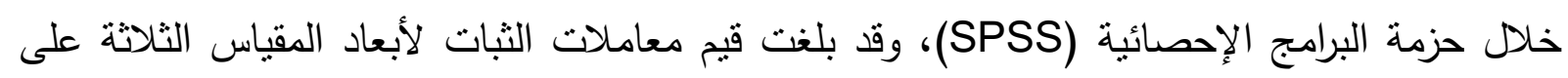

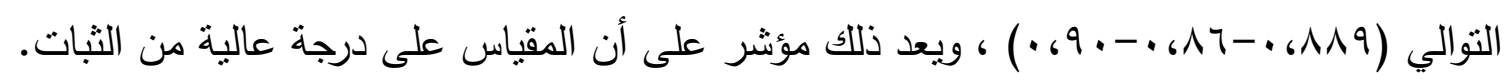
كما تم حساب ثبات مقياس باستخدام إعادة المقياس بتطبيق المقياس على عينة بلغ عددهم (•r)

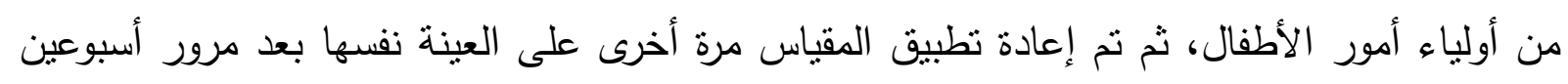

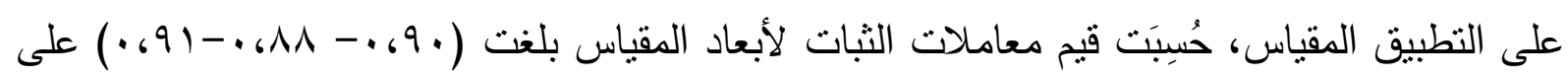
التوالي، ويدل ذللك على أن المقياس يتمتع بدرجة عالية من الثبات.

ץ- ؟- إعداد الصورة النهائية للمقياس: بعد التأكد من صدق المقياس وثباته في ضوء ما سبق،

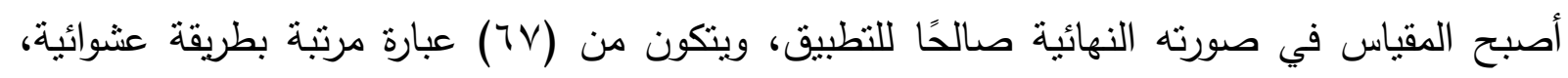

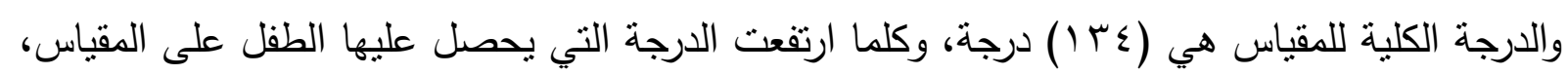

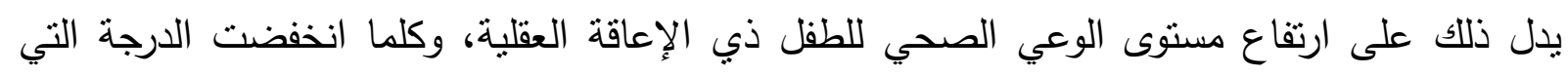

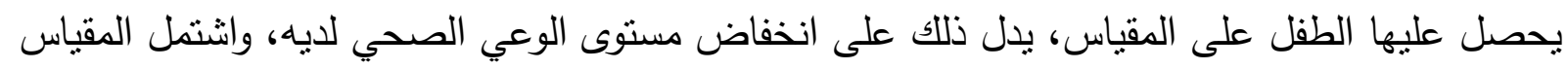
على ما يأني : باليها 
- البعد الأول : النظافة الثخصية، ويتكون من(YV) عبارة.

- البعد الثاني: التغذية السليمة، ويتكون من (•†) عبارة. - البعد الثالث: الوقاية من الأمراض والمخاطر ، ويتكون من (·r) عبارة.

نتائج الدراسة وتفسيرها: بالنسبة للإجابة عن أسئلة الاراسة الفرعية (الأول والثاني والثالث)، فقد تمت الإجابة عنهم ضمن إجراءات الدراسة التي سبق الإثارة إليها.

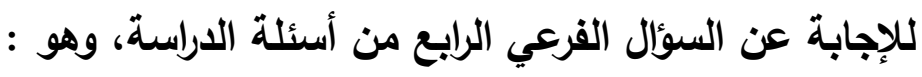

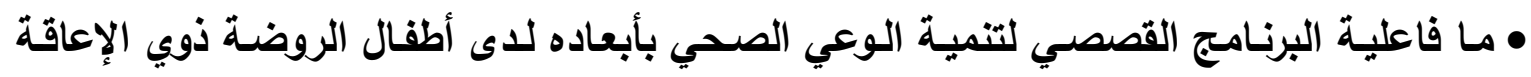
العقلية البسيطة؟ - إن تطلب الإجابة عن هذا السؤال التحقق من صحة فروض الدراسة الأول والثاني والثالث : الفرض الأول: يوجد فرق دال إحصائًًا عند مستوى > 0.05 بين منوسطي درجات أطفال المجموعـة

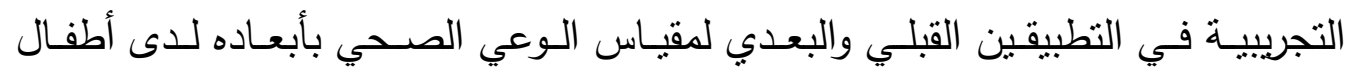
الروضة ذوب الإعاقة العقلية البسيطة لصالح النطبيق البعدي. ولاختبار صحة هذا الفرض حُسبت نسبة الكسب المعدلة لـ " بليك " للنمو في مقياس الوعي الصحي لدى أطفال المجموعة التجريبية باستخدام المعادلة الآتية: Blacke Modified Gain Ratio $=\frac{Y-X}{P-X}+\frac{Y-X}{P}$ حيث : = منوسط درجات الأطفال في التطبيق القبلي لمقياس الوعي الصحي بأبعاده. متوسط درجات الأطفال في التطبيق البعدي لمقياس الوعي الصحي بأبعاده. Y

النهاية العظمى التي يمكن الحصول عليها في المقياس القبلي أو البعدي ، ويعد البرنامج فعالًا

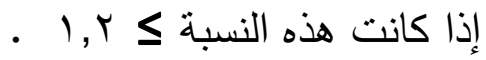
ويوضح جدول (0) نسبة الكسب المعدلة لـ " بليك " للنمو في مقياس الوعي الصحي كل بعد على حدة وكل الأبعاد مجتمعة لدى أطفال المجموعة التجريبية : 


\section{جدول (0 ) نسبة الكسب المعدلة لـ " بليك " للنمو في مقياس الوعي الصحي لكل بعد على حلة وكل الأبعاد مجتمعة لدى أطفال المجموعة التجريبية}

\begin{tabular}{|c|c|c|c|c|c|c|}
\hline نسبة الكسب & العظمى للاختبار & فتوسط درجات الأطفال & فتوسط درجات الأطفال & الأطفال & مقياس الوعي الصحي & s \\
\hline 1.35 & $0 \leqslant$ & 46.17 & 16.25 & \multirow{4}{*}{12} & | بعد النظافة الثخصية. & 1 \\
\hline 1.31 & 40 & 34 & 12.67 & & بعد التغذية السليمة. & r \\
\hline 1.28 & 40 & 32.42 & 10.83 & & | بعد الوقاية من الأمراض والأخطار. & $r$ \\
\hline 1.32 & 134 & 112.58 & 39.75 & & مقياس الوعي الصحي (الأبعاد مجتمعة). & $\varepsilon$ \\
\hline
\end{tabular}

تتير النتائج كما يوضحها جدول (0) إلى صحة الفرض الأول؛ حيث تزيد نسبة الكسب المعدلة في

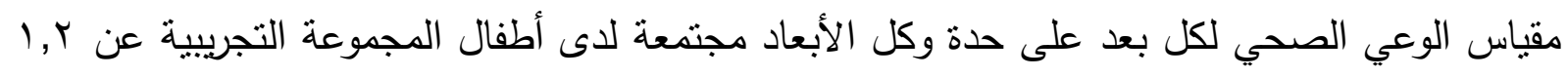

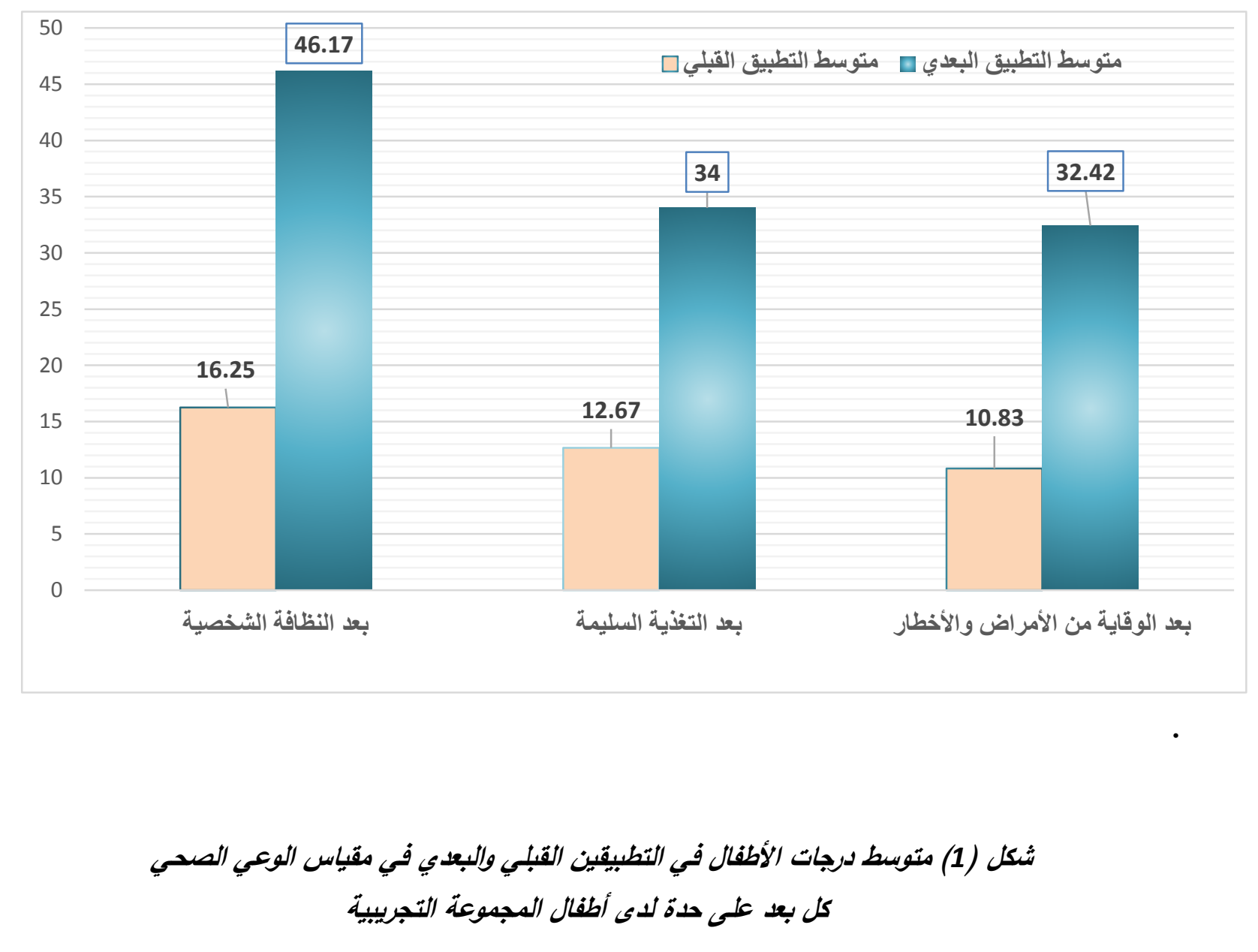




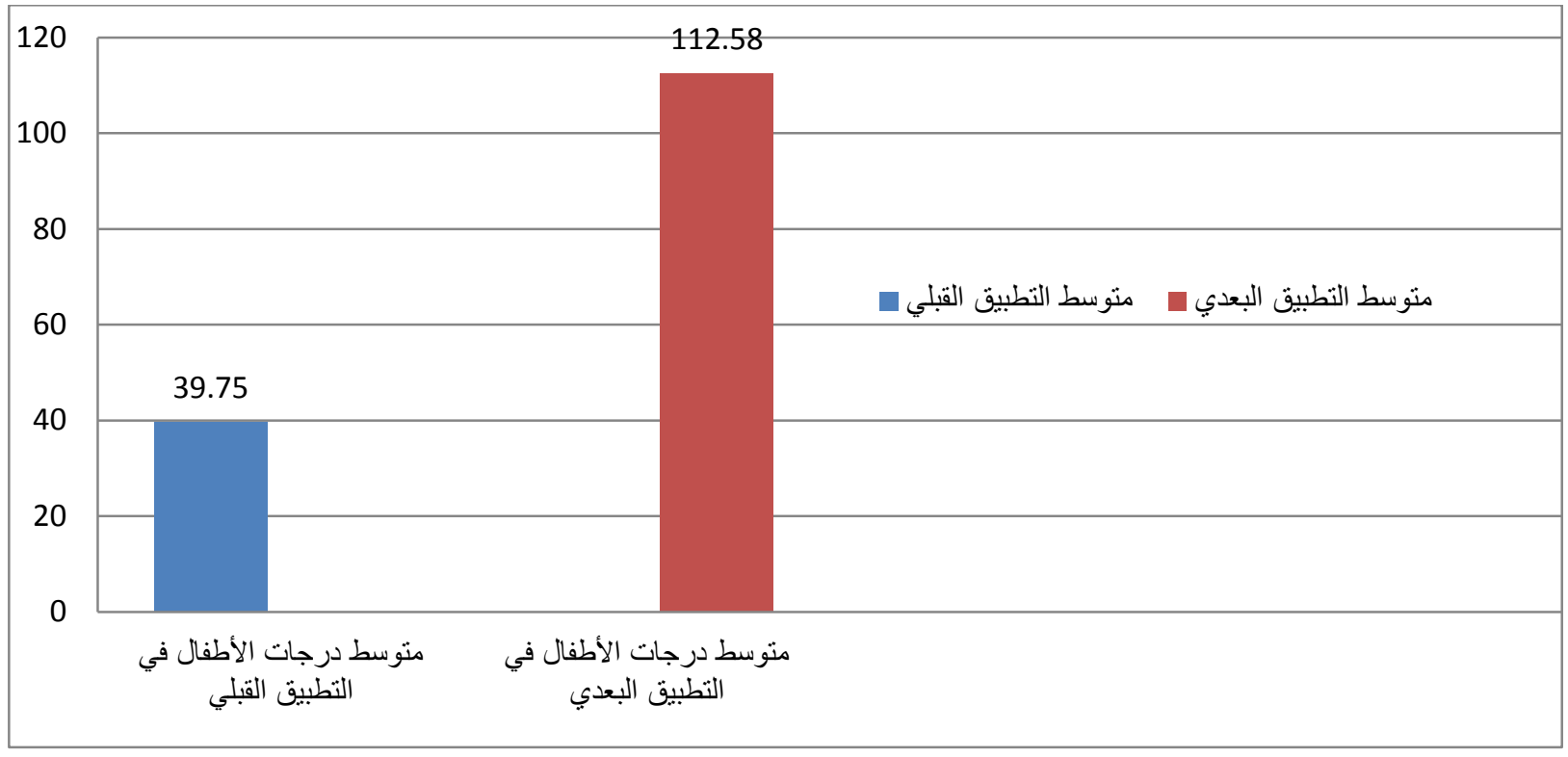

شكل (2) متوسط درجات الأطفال في التطبيقين القبلي والبعدي لمقياس الوعي الصحي(الأبعاد مجتمعة) لدى أطفال المجبوعة التجريبية

وفيما يلي تفسير لهذه التتائج : - - تفسير النتائج الخاصة ببعد النظافة الشخصية: يوضح جدول (T) نسبة الكسب المعدلة لـ " بليك " للنمو في مقياس الوعي الصحي في بعد النظافة الشخصية لدى أطفال المجموعة التجريبية : جدول (آ) نسبة الكسب المعدلة لـ " بليك " للنمو في مقياس الوعي الصحي في بعد النظافة الشخصية لدى أطفال المجموعة التجريبية

\begin{tabular}{|c|c|c|c|c|}
\hline نسبة الكسب & دالعة النهاية & متوسط درجات الأطفال في & متوسط درجات الأطفال في & الأطفال \\
\hline 1.35 & $0 \leqslant$ & 46.17 & 16.25 & Ir \\
\hline
\end{tabular}

ويوضح جدول (†) زيادة نسبة الكسب المعدلة في بعد النظافة الثخصية لدى أطفال المجموعة التجربيية

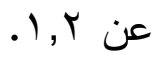
ويوضح الثكل ( r) متوسط درجات الأطفال في التطبيقين القبلي والبعدي في مقياس الوعي الصحي في بعد النظافة الشخصية لدى أطفال المجموعة التجريبية . 
فاعلية برنامج قصصي لتنمية الوعي الصحي لاى أطفال الروضة ذوي الإعاقة العقلية البسيطة

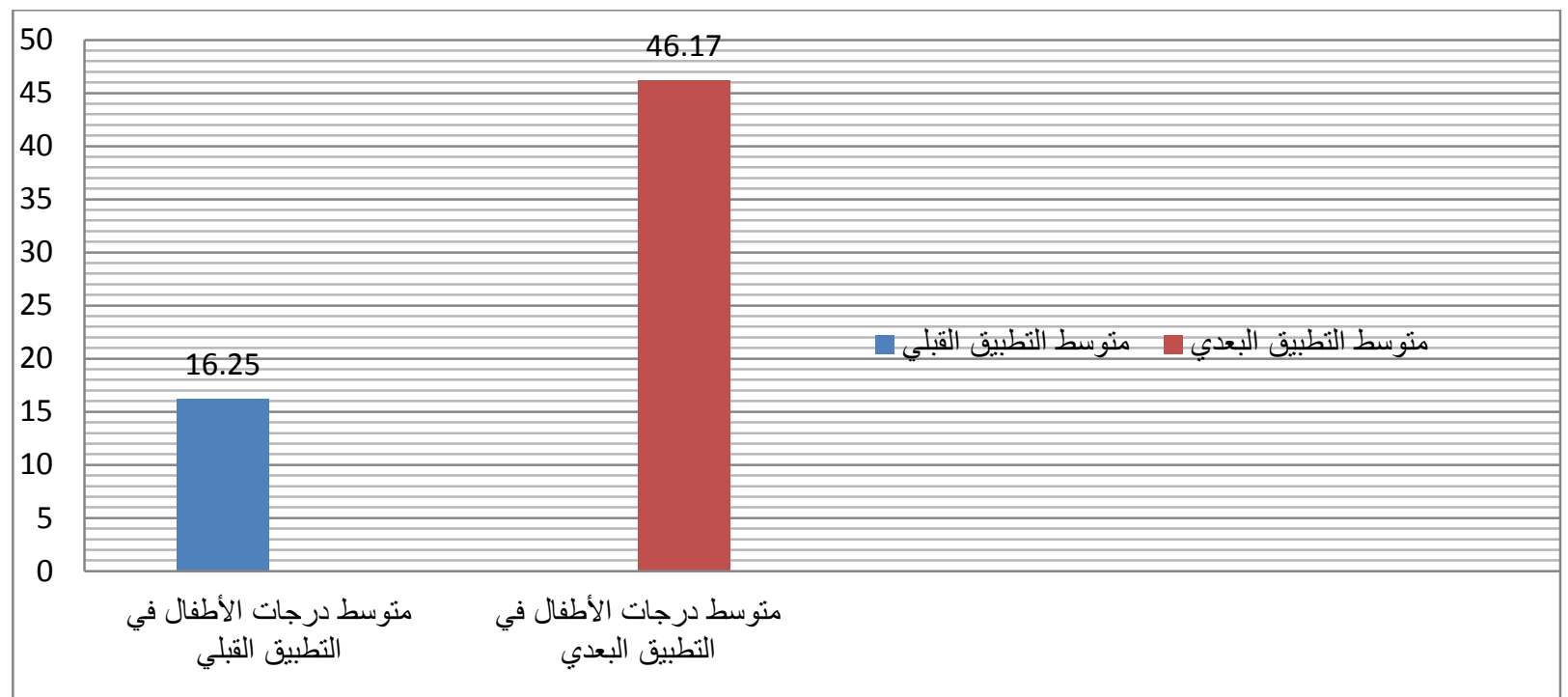

شكل (\%) متوسط درجات الأطفال في التطبيقين القبلي والبعدي في مقياس الوعي الصحي

في بعد النظافة الشخصية لدى أطفال المجموعة التجريبية

وتعزو هذه النتيجة لمقياس الوعي الصحي في بعد النظافة الشخصية للأسباب الأتية:

ا. تتظيم محتوى البرنامج القصصي في ضوء قائمة المعارف والاتجاهات والسلوكيات الصحية التي يحتاج إليها أطفال الروضة ذوي الإعاقة العقلية البسيطة لتمية وعيهم الصحي لنظافتهم الثخصية.

r. البرنـامج القصصـي قد سـاعد في إكسـاب أطفـال الروضـة ذوي الإعاقـة العقليـة البسـيطة العديد من المعارف الخاصة بالنظافة الثخصية من خلال بناء حوار القصص المقدمة لهم

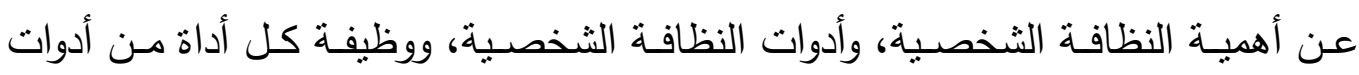
النظافـة الثخصية، والمحافظـة على أدوات النظافـة الثخصية، بالإضـافة إلى مـا توفره القصص من مناقثة الأطفال في الدروس المستفادة المقدمة لهم.

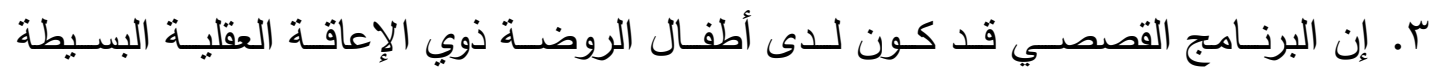
الاتجاهات الإيجابية نحو النظافة الثخصية من خلال حب الأطفال لأبطال القصص، الإسل وحرص جميع الأبطال على النظافة الثخصية، مما كون لدى الأطفال اتجاهات ايجابية نحو النظافة الثخيصة.

عـ أكسـب البرنـامج أطفـال الروضــة ذوي الإعاقـة العقليـة أداء وممارسـة ســوكيات النظافـة الثخصية لتتمية الوعي الصحي لديهم، كنظافة اليد، وتقليم الأظفار (الأظافر)، ونظافة

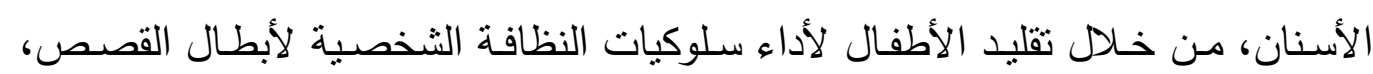
ومحاكاتهم لحركات المعلمة في أداء سلوكيات الخاصـة بالنظافة الثخصية أثناء سرد كل 
هـ توفير لكل طفل مـن أطفال المجموعـة التجريبيـة أدوات النظافـة الشخصية الخاصـة بـه،

واستخدامها أثناء أحداث القصص في تقليد أداء سلوكيات النظافة الثخصية لأبطالها.

7 7. توفير معززات مادية من أدوات النظافة الثخصية المستخدمة في القصص مثل (المشط

وفرشـاة للثـعر ، وفرشـاة أسـنان، وصـابونة صـغيرة، ومبـرد أظـافر خشـب، ومـرآة صـغيرة،

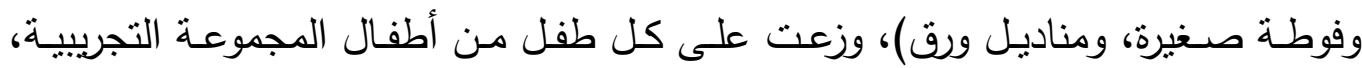

بالإضـافة إلىى المعززات المعنويـة ( كالثتـاء والمـدح والتصفيق)؛ مدـا سـاعد على تتميـة

الوعي الصحي لاى الأطفال في بعد النظافة الشخصية.

- تفسير النتائج الخاصة ببعد التغذية السليمة:

يوضح جدول (V) نسبة الكسب المعدلة لـ " بليك " للنمو في مقياس الوعي الصحي في بعد

التغذية السليمة لاى أطفال المجموعة التجريبية :

جلول (V) نسبة الكسب المعدلة لـ " بليك " للنمو في مقياس الوعي الصحي في بعد التغنية السليمة للى أطفال المجبوعة التجريبية

\begin{tabular}{|c|c|c|c|c|}
\hline نسبة الكسب & العظمى للاختبار التهاية & متوسط درجات الأطفال في & متوسط درجات الأطفال في & الأطفال \\
\hline 1.31 & 40 & 34 & 12.67 & Ir \\
\hline
\end{tabular}

ويوضح جدول (V) زيادة نسبة الكسب المعدلة في بعد الوقاية التغذية السليمة لدى أطفال المجموعة التجريبية عن r, 1، يوضح شكل (ع) متوسط درجات الأطفال في التطبيقين القبلي والبعدي في مقياس الوعي الصحي في بعد التغذية السليمة لدى أطفال المجموعة التجريبية. 


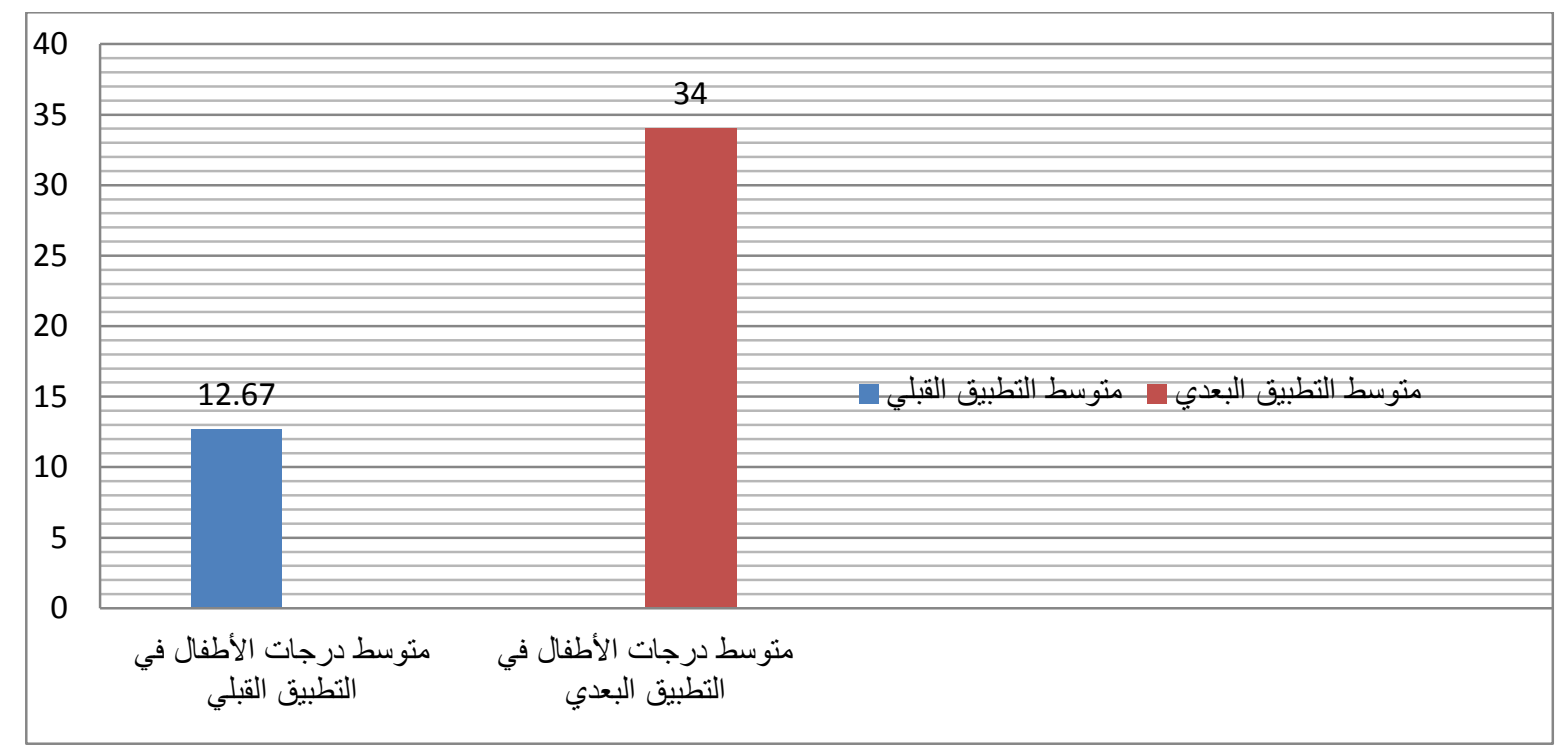

\section{شكل (ء) متوسط درجات الأطفال في التطبيقين القبلي والبعدي في مقياس الوعي الصحي في بعد التغذية السليمة لدى أطفال المجدوعة التجريبية}

وتعزو هذه النتيجة لمقياس الوعي الصحي في بعد التخذية السليمة للأسباب الأثية:

ا. تتظيم محتوى البرنامج القصصي في ضوء قائمة المعارف والاتجاهات والسلوكيات الصحية التي يحتاج إليها أطفال الروضة ذوي الإعاقة العقلية البسيطة لتتمية الوعي الصحي لديهم في بعد التغذية السليمة.

r. سـاعد البرنـامج القصصـي مـن خـلال الدروس المسـتفادة للقصـص المقدمـة في إكسـاب المعـارف والمعلومـات الخاصـة بأهميـة التغذيـة السـليمة، وفوائدها على جسـم الإنسـان

وصحته.

r. كون البرنامج القصصي الاتجاهات الإيجابية لتتاول الأغذية الصحية السليمة المفيدة من خـلال تقليد الأطفال لأبطـال القصص التي كانت نتتـاول دائمًا الأطعمـة المفيدة وشـرب العصائر الطازجة، فتكون لديهم اتجاهات ايجابية نحو التغذية السليمة. ع. أكسب البرنامج القصصي أطفال الروضـة ذوي الإعاقة العقلية سلوكيات التغذية الصحية السليمة وآداب الطعام لتتمية الوعي الصحي لديهم، كتناول الفاكهة والخضروات الطازجة، وشـرب المـاء النظيف والعصـائر الطازجـة المفيدة، والبعد عن تتـاول الحلويـات والمعلبـات والأطعمـة ذات الألوان الصـناعية، والالتزام بكميـة الطعام المسموح لـه بتتاولها، وتم ذلك بتقليد الأطفال لأبطال القصة ومحاكاتهم في تتاول الأطعمة الصحية. ه. وفر البرنامج القصصي معززات مادية من أدوات المائدة التي استخدمها أبطال القصص، مثل (معلقة وشوكة وطبق بلاستيك)، و ( فاكهة وخضروات طازجة، ومنها تفاح، وموز ، 
وخيار ، وعصائر طازجة، وأطباق سلطة طازجة )، وزعت على جميع أطفال المجموعة

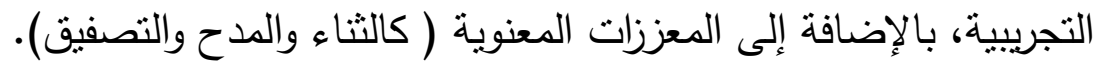
- تفسير النتائج الخاصة ببعد الوقاية من الأمراض والأخطار: يوضح جدول (^) نسبة الكسب المعدلة لـ " بليك " للنمو في مقياس الوعي الصحي في بعد الوقاية من الأمراض والأخطار لاى أطفال المجموعة التجريبية : جدول (1) نسبة الكسب المعلة لـ " بليك " للنمو في مقياس الوعي الصحي في بعد الوقاية من الأمراض والأخطار للدى أطفال المجموعة التجريبية

\begin{tabular}{|c|c|c|c|c|}
\hline نسبة الكسب & العظمى للاختبار & متوسط درجات الأطفال في & متوسط درجات الأطفال في & الأطفال \\
\hline 1.28 & 40 & 32.42 & 10.83 & ir \\
\hline
\end{tabular}

ويوضح جدول (^) زيادة نسبة الكسب المعدلة في بعد الوقاية من الأمراض والأخطار لدى أطفال

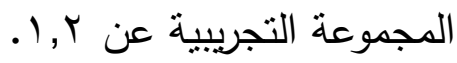
يوضح شكل (0) متوسط درجات الأطفال في التطبيقين القبلي والبعدي في مقياس الوعي الصحي في بعد الوقاية من الأمراض والأخطار لاى أطفال المجموعة التجريبي.

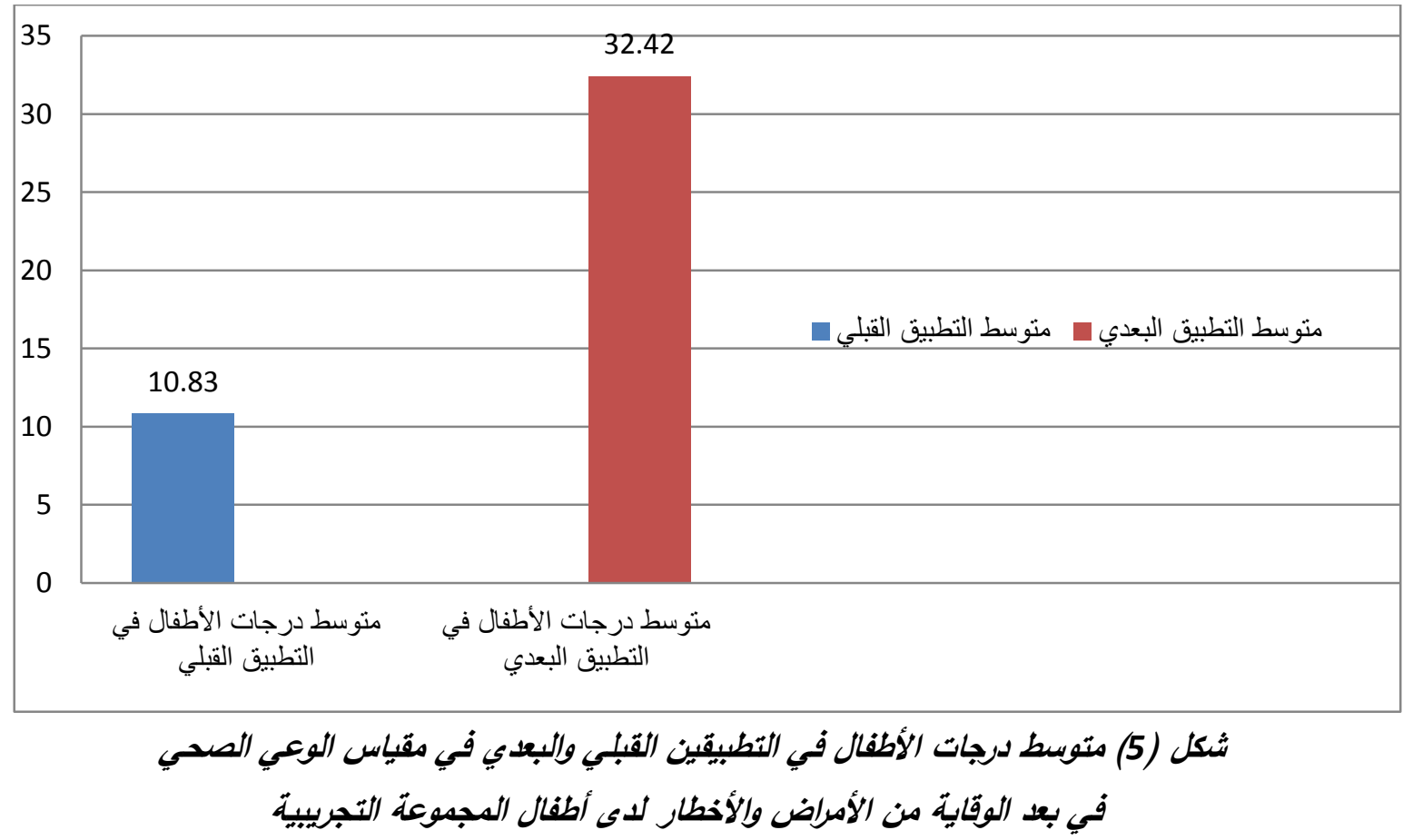


وتعزو هذه النتيجة لمقياس الوعي الصحي في بعد الوقاية من الأمراض والأخطار للأسباب الأثية: 1. تنظيم محتوى البرنامج القصصي في ضوء قائمة المعارف والاتجاهات والسلوكيات الصحية التي يحتاجها أطفال الروضة ذوبي الإعاقة العقلية البسيطة لتتمية الوعي الصحي فئدي

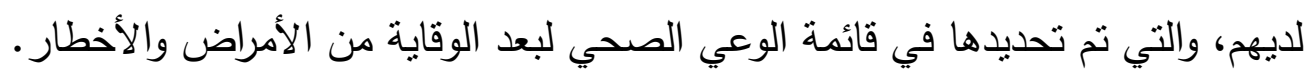
r. سـاعد البرنـامج القصصسي في إكسـاب المعـارف والمعلومـات والاتجاهـات والسـلوكيات الصحية الخاصة بطرق الوقاية من الأمراض والأخطار .

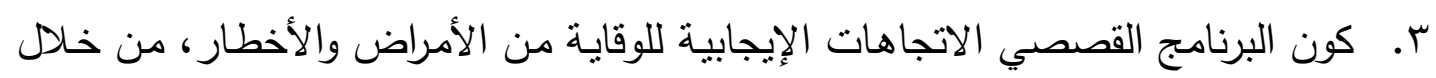

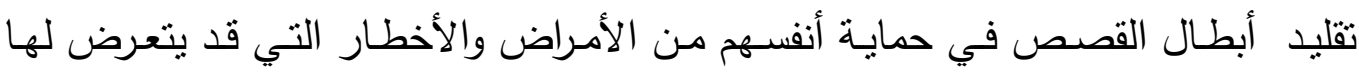
أطفال الروضة ذوي الإعاقة العقلية البسيطة.

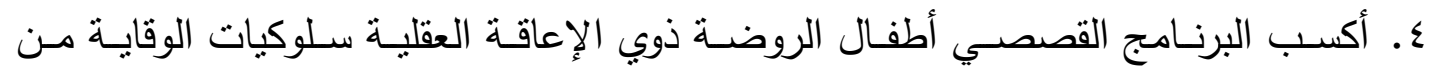

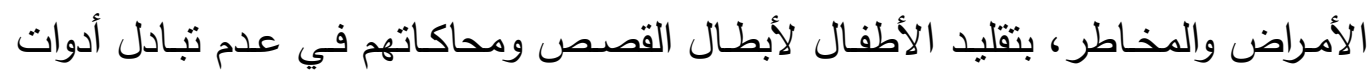

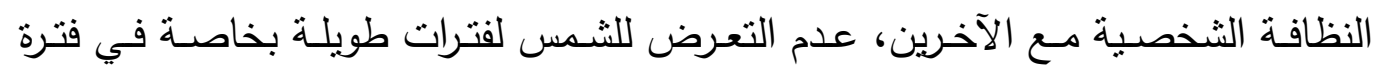
الظهيرة، استخدام المنديل أثناء السعال والعطس، عدم تتاول الطعام من الباعة الجائلين،

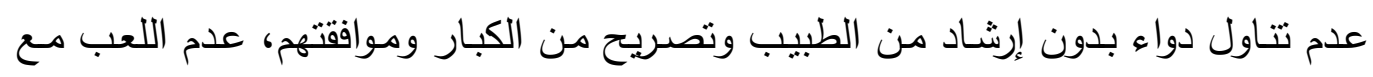

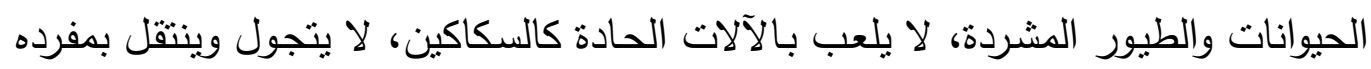

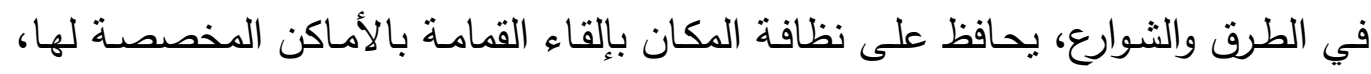
يبتعد عن من عندهم أمراض معدية، يحافظ على الماء والطعام من التلوث.

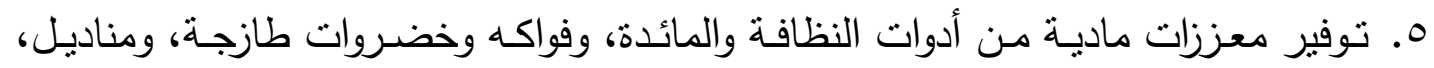
بالإضافة إلى المعززات المعنوية ( كالثناء والمدح والتصفيق).

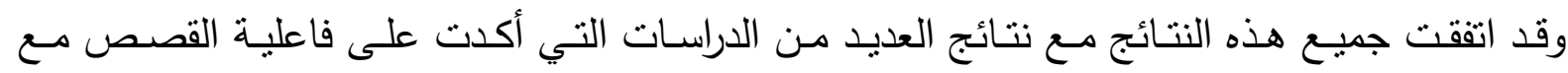

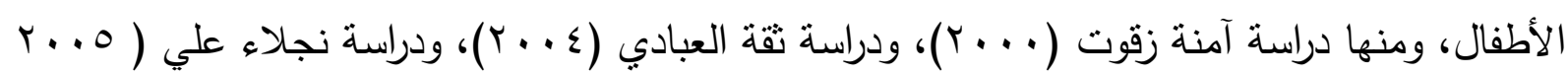

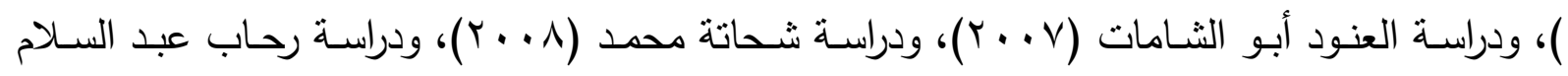

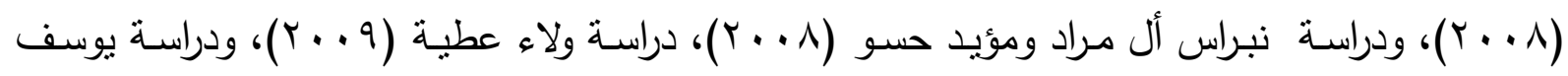

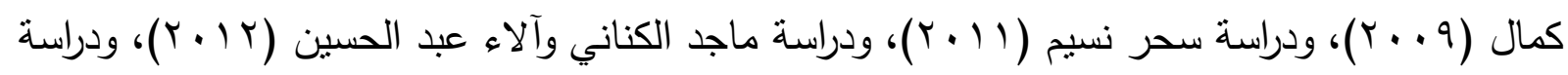

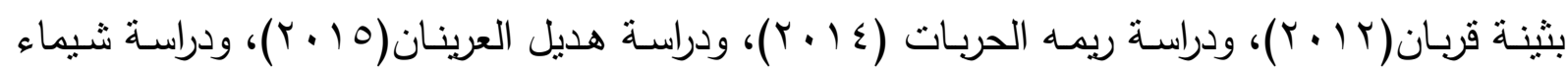

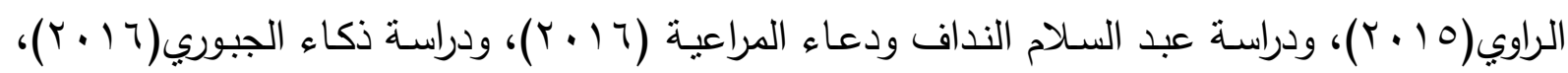

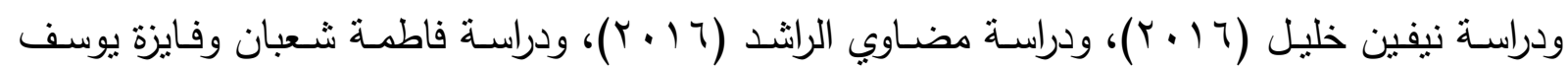

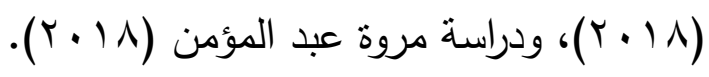


كما تتقق هذه النتائج مع نتائج العديد من الدراسات التي أثنتت فاعلية القصص مع الأطفال ذوبي

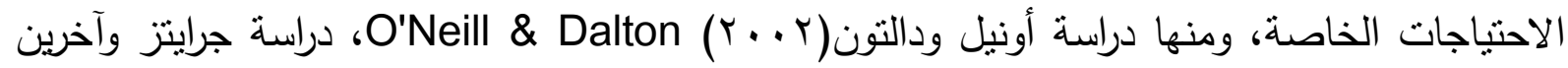

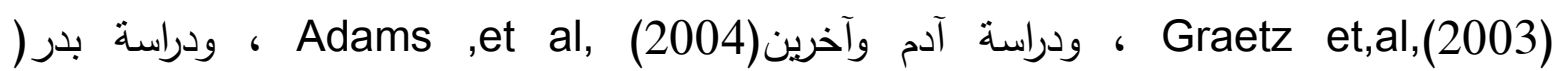

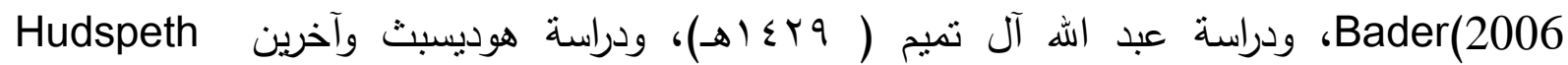

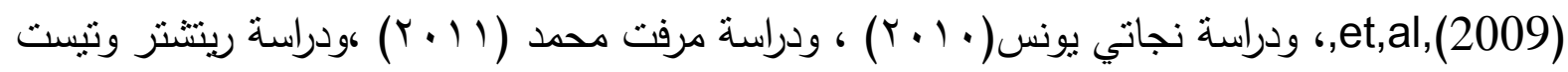

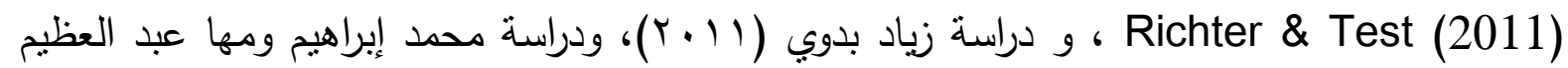

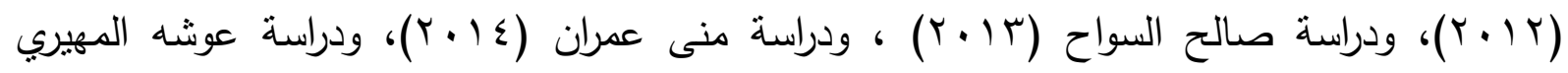

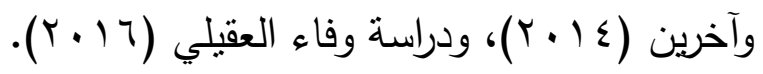

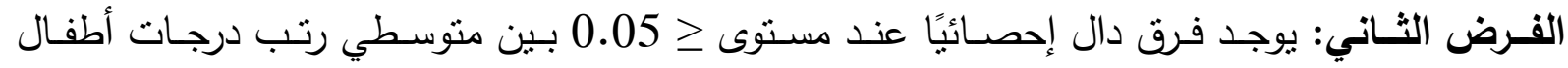

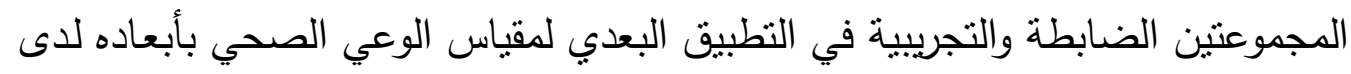
أطفال الروضة ذوي الإعاقة العقلية البسيطة لصالح أطفال المجموعة التجريبية. لاختبار صحة هذا الفرض طبق اختبار "مان ويتتي" Mann-Whitney U test باستخدام حزمة

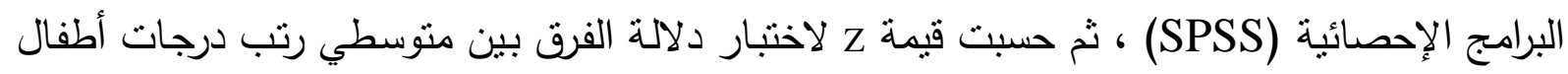
المجموعتين الضابطة والتجريبية في التطبيق البعدي لدقياس الوعي الصحي بأبعاده لادى أطفال الروضية

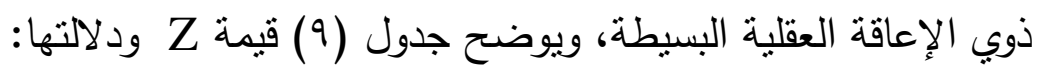

جلول (q): قييم Z لاختبار دلالة الفرق بين متوسطي رتب درجات أطفال المجموعتين الضابطة

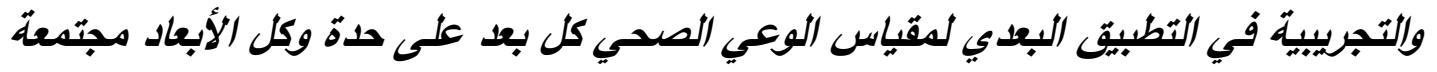

\begin{tabular}{|c|c|c|c|c|c|c|c|}
\hline مستوى الدلادة & 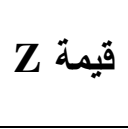 & مجموع & متوسط & الأطفال & المجموعة & مقياس الوعي الصحي & b \\
\hline \multirow[t]{2}{*}{ دال } & \multirow{2}{*}{-4.168} & 78 & $7,0$. & \multirow{2}{*}{ Ir } & الضابطة & \multirow{2}{*}{ بعد النظافة الشخصية. } & \multirow{2}{*}{1} \\
\hline & & 222 & $11,0$. & & التجريبية & & \\
\hline \multirow[t]{2}{*}{ دال } & \multirow{2}{*}{-4.180} & 78 & $7,0$. & \multirow{2}{*}{ ir } & الضابطة & \multirow{2}{*}{ بعد التظذية السليمة. } & \multirow{2}{*}{$r$} \\
\hline & & 222 & $11,0$. & & التجريبية & & \\
\hline \multirow[t]{2}{*}{ 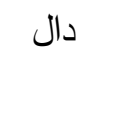 } & \multirow{2}{*}{-4.186} & 78 & $7,0$. & \multirow{2}{*}{ ir } & الضابطة & \multirow{2}{*}{ بعد الوقاية من الأمراض والأخطار } & \multirow{2}{*}{$r$} \\
\hline & & 222 & $1 \wedge, 0$. & & التجرييية & & \\
\hline \multirow{2}{*}{ 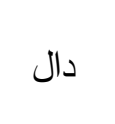 } & \multirow{2}{*}{-4.163} & 78 & $7,0$. & \multirow{2}{*}{ ir } & الضابطة & \multirow{2}{*}{ مقياس الوعي الصحي(الأبعاد مجتمعة). } & 6 \\
\hline & & 222 & $1 \wedge, 0$. & & التجريبية & & 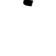 \\
\hline
\end{tabular}




$$
\text { يوضح جدول (9) أن قيمة Z دالة عند مستوى } 0.05 \text {. }
$$
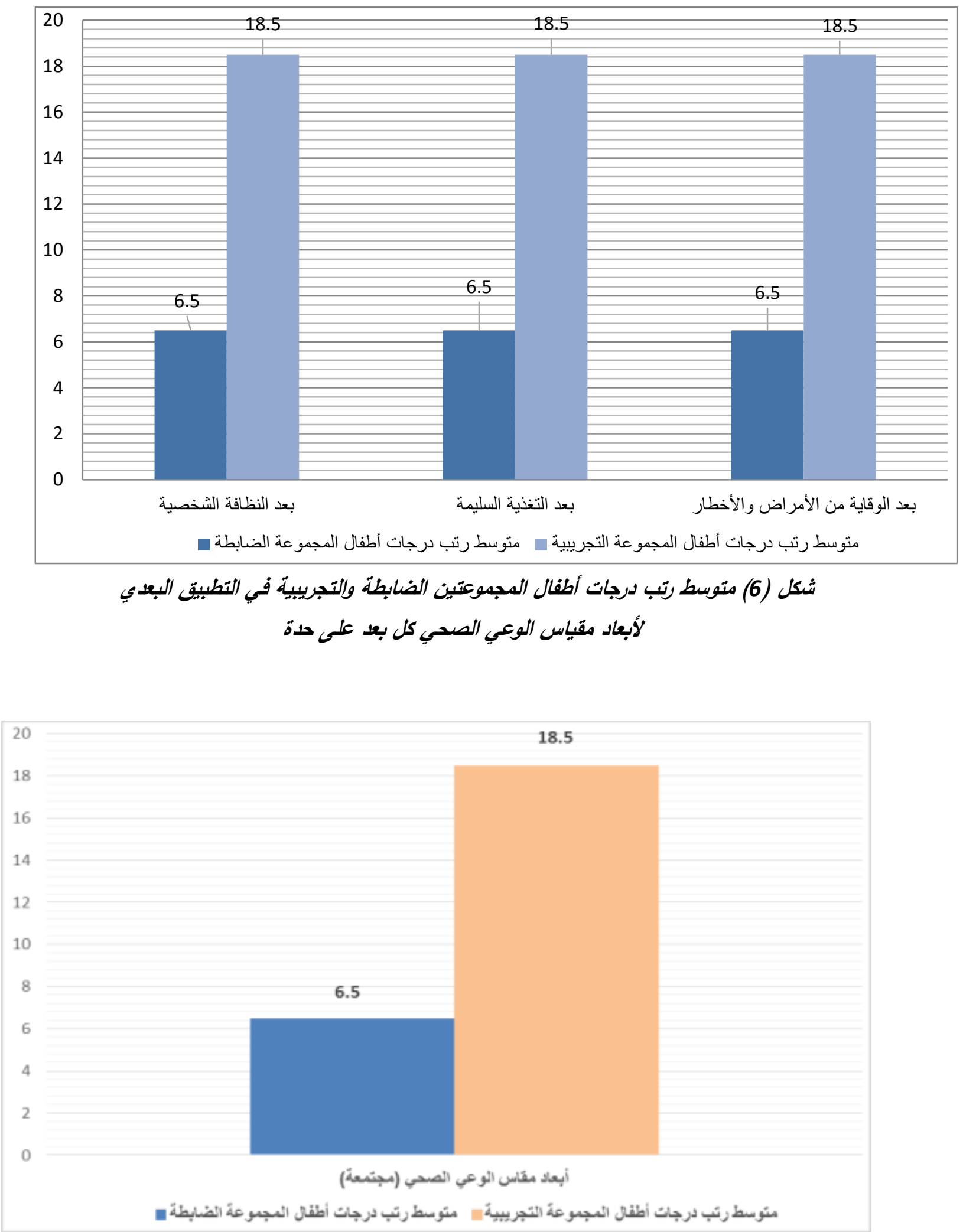

شكل (V) متوسط رتب درجات أطفال المجموعتين الضابطة والتجريبية في التطبيق البعدي

لمقياس الوعي الصحي (الأبعاد مجتمعة) 
وتشير نتيجة قيم Z لاختبار دلالة الفرق بين متوسطي رتب درجات أطفال المجموعتين الضـابطة والتجريبية في التطبيق البعدي لأبعاد مقياس الوعي الصحي كل بعد على حدة وكل الأبعاد مجتمعة إلى صحة الفرض الثاني.

الفـرض الثالث: لا يوجد فرق دال إحصـائيًا عند مستوى ج 0.05 بين متوسطي رتب درجـات أطفال المجموعة التجريبية في التطبيقين البعدي والتتبحي لمقياس الوعي الصحي لدى أطفال

الروضة ذوي الإعاقة العقلية البسيطة.

لاختبار صحة هذا الفرض طبق اختبار "مان ويتتي" Mann-Whitney U test باستخدام حزمة

البرامج الإحصائية (SPSS) ، ثم حسبت قيمة z لاختبار دلالة الفرق بين متوسطي رتب درجات أطفال المجموعة التجربيية في التطبيق البعدي والتطبيق التتبعي لمقياس الوعي الصحي لدى أطفال الروضـة ذوي الإعاقة العقلية البسيطة، ويوضح جدول ( • () قيمة Z ودلالتها: جدول ( ( 1): قيم Z لاختبار دلالة الفرق بين متوسطي ثتب درجات أطفال المجموعة التجبيبية في

\begin{tabular}{|c|c|c|c|c|c|c|c|}
\hline مستوى الدلالة & قيمة Z & مجموع الرتب & متوسط الرتبة & الأطفال & القياس & مقياس الوعي الصحي & p \\
\hline \multirow{2}{*}{ غير دال } & \multirow{2}{*}{-0.087} & 148.5 & 12.38 & \multirow{2}{*}{ Ir } & البعدي & \multirow{2}{*}{ مقياس الوعي الصحي. } & \multirow{2}{*}{1} \\
\hline & & 151.5 & 12.62 & & التتبعي & & \\
\hline
\end{tabular}

يوضـح جدول ( • () أن قيمـة Z غير دالـة عند مستوى 0.05 أي عدم وجود فروق بين درجات الأطفال المجموعة التجريبية في التطبيقين البعدي والتتبعي، وتشير هذه النتيجة إلى صحة الفرض الثالث.

وترجع فاعلية البرنامج القصصي لتنمية الوعي الصحي لاى أطفال الروضة ذوي الإعاقة العقلية البسيطة، للأسباب الآتية:

ا ـ بناء البرنامج القصصي في ضوء قائمة المعارف والمهارات والسلوكيات الصحية التي يحتاجها أطفال الروضة ذوي الإعاقة العقلية البسيطة عمرهم يتراوح بين (0 إلى V) سنوات؛ لتتمية الوعي الصحي لديهم.

r. قد استغل البرنامج ميل الأطفال الفطري للقصص وحبهم للاستماع لها، وتم عرض المعارف والمعلومات والاتجاهات والسلوكيات الصحية من خلا القصص لتتمية الوعي الصحي لهم، وقد

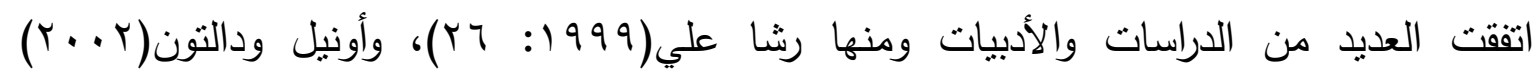
O'Neill \& Dalton

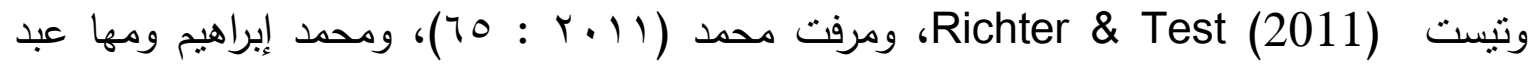




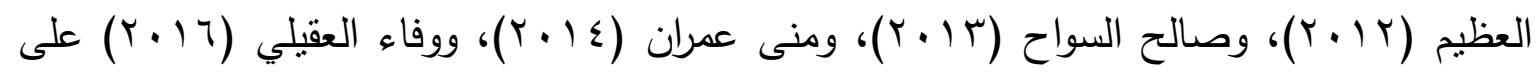
ميل هؤلاء الأطفال إلى القصص والانصات لها. r. تقديم البرنامج القصصي ساعد في تقصص الأطفال مع أبطال القصص المعروضة عليهم لحبهم لها، ولذلك تم تصميم شخصيات وأبطال القصص تمنلك معارف واتجاهات، وتمارس السلوكيات الصحية؛

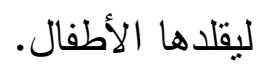

ـ. وفر البرنامج القصصي أثناء الموقف التعليمي جوًا من المتعة والفكاهة والمرح يفضله أطفال الروضة ذوي الإعاقة العقلية البسيطة؛ مما ساعد في تتمية الوعي الصحي لديهم. ه. اختيار عنوان لكل قصة بسيط وسهل ومعبر عن مضمونها، ليسهل على الأطفال حفظ عنوان القصة.

7. أحداث كل قصة من قصص البرنامج بسيطة، ومنسلسلة، ومن حياة الطفل ذي الإعاقة العقلية الواقعية، ونهاية أحداث جميع القصص سعيدة حتى توفر جوًا من البهجة والسعادة للأطفال. V . بناء حبكة وعقدة واحدة لكل قصة من قصص البرنامج؛ حتى يسنطيع كل طفل فهمها ومتابعتها. ^. بناء قصص البرنامج في ضوء ما يناسب أطفال الروضة ذوي الإعاقة العقلية من عدد شخصيات لا لاهي

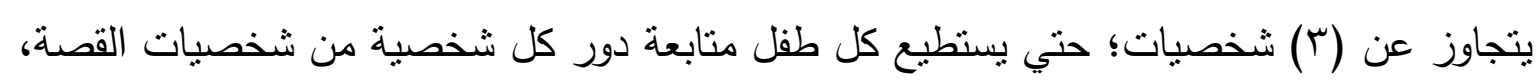

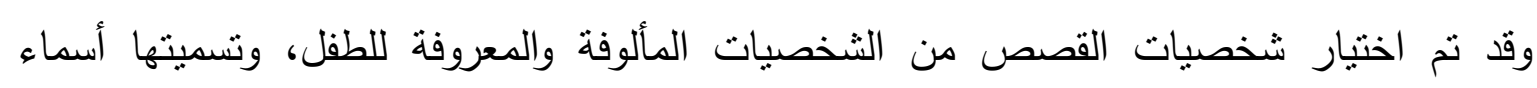
متداولة ومستخدمة في حياته.

9 . قدمت القصص للأطفال بالعامية حتى يسهل عليهم فههها، كما تم نوظيف المفردات اللغوية الثائعة

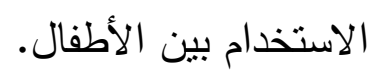

• (. صممت القصص في الزمان الحاضر الذي يعيثه الطفل، والبعد عن الزمان القديم أو الحديث.

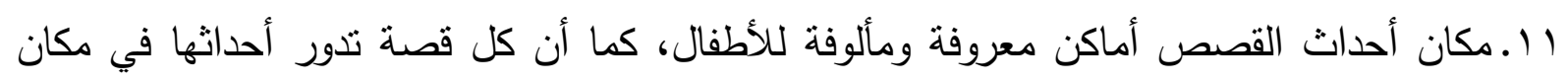
واحد؛ فقصة الحفلة أحداثها في المنزل، وقصة مائدة الطعام أحداثها في المنزل، وقصة البطل أحداثها في ملعب الروضة، قصة الأسنان الحلوة أحداثها في المنزل، وقصة الحديقة أحداثها في حديقة الروضة.

rا. التصميم المادي للقصص على شكل اسكتشات أو دفتر قلاب؛ ليسهل على الطفل النظر إليها ومنابعة أحداثها بشكل متسلسل ومتتابع، ووضع صورة معبرة عن القصة على الغلاف لجذب انتباه الأطفال للقصة، وحثهم على معرفة أحداثها ومتابعتها. 
با ا.تصميم وتوظيف صور ورسوم القصة بألوان زاهية وواقعية ومعبرة عن أحداث كل القصة، بالإضافة إلى إبراز شخصيات القصة مع تقليل عناصر الخلفية للصور والرسوم، قد ساعد في استمرار الأطفال في متابعة القصة، وتتمية الذاكرة البصرية للأطفال لأحداث القصص وتذكر ممارسة أبطال القصة للسلوك الصحي؛ مما ساهم في تتمية الوعي الصحي لدى هؤلاء الأطفال.

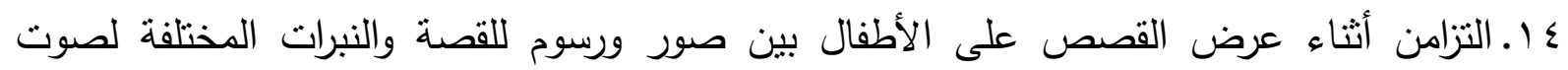
المعلمة مع حركتها وتقليدها لأداء السلوك الصحي لأبطال كل قصة، وحثها على أن يقلد الأطفال

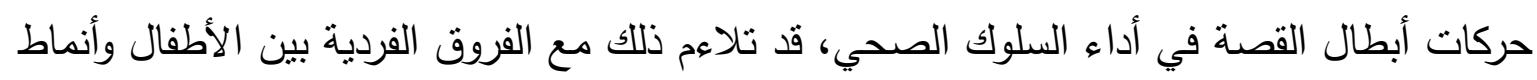
تعلمه المختلفة؛ عمل ذلك على تيسير إكساب الأطفال المعارف والاتجاهات وممارسة السلوكيات الصحية الخاصة بكل قصة. 1 ا.تقديم البرنامج القصصي لأدوات الخاصة بكل قصة من قصص البرنامج لكل طفل، ومنها أدوات

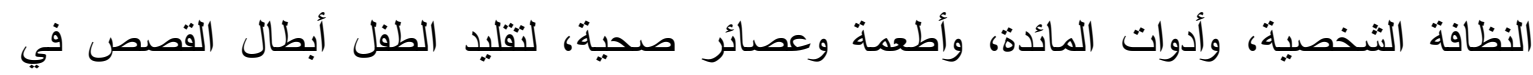
ممارسة السلوك الصحي. 7 ا.التتوع الذي وفره البرنامج القصصي من خلال سرد المعلمة للقصة وتقليد الأطفال لحركات أبطال القصة أثناء السرد، ثم تمثيل الأطفال لأدوار شخصيات القصة، قد أدى إلى تثبيت المعارف والاتجاهات والسلوكيات الصحية لدى الأطفال.

V ا ـالاجتماع مع أولياء أمور أطفال المجموعة التجريبية لعرض البرنامج القصصي عليهم؛ لتتمية الوعي الصحي لأطفالهم في هذه المرحلة، كما تم التعاون المتواصل طوال فترة البرنامج. 1 اـ الاستفادة من حب أطفال الروضة ذوب الإعاقة العقلية للنشاط والحركة، وجعلهم يقلدون حركات أبطال القصص المقدمة لهم في ممارسة السلوكيات الصحية من خلال أحداث القصص سواء داخل حجرة النشاط أم حديقة الروضة أم ملعب الروضة، وبالثالي وفر البرنامج الممارسة العملية للسلوكيات الصحية الصحيحة، كما ساهم في زيادة الدافعية لمتابعة القصص. 9 ا. ساعدت الجلسات الجماعية التي وفرها البرنامج على تكوين علاقات اجتماعية وتواصلية بين أطفال الجلسة الواحدة، وعلى تمثيل الأطفال بالتبادل لأدوار القصص مما أضاف جوًا من التعاون فيما لئه بينهم. • r. وفر البرنامج معززات منتوعة قدمت للأطفال، والتي تتوعت بين المعززات المادية، ومنها (أدوات النظافة الثخصية ومناديل ورق، وأدوات المائدة، وفاكهة وخضروات طازجة، وعصائر طازجة)، 
والمعززات المعنوية (كالثناء، والتصفيق، والمدح)؛ مما كون اتجاهات إيجابية نحو ممارسة السلوك • الصحي الصحيح

اץ. تكرار كل قصة من القصص مرتين على الأطفال، وتكرار ممارسة السلوكيات الصحية التي تحتويها كل قصة، وتمثيل كل طفل لأبطالها، والمناقثات للاروس المستفادة من كل قصة، ساعد في تثبيت السلوكيات الصحية لدى أطفال الروضة ذوي الإعاقة العقلية البسيطة. r. ب.ملاحظة المعلمة لأداء كل طفل من أطفال المجموعة التجريبية على حده أثناء سردها لأحداث القصص، وأثناء تمثيله لأبطال القصص، وتوجيه المعلمة( البدني واللفظي) لأداء الأطفال أثناء تقليد أبطال القصص، وبالتالي وفر البرنامج التخذية الراجعة الفورية لأطفال المجموعة التجريبية. r r.تقديم المراجعة المستمرة في بداية كل جلسة على المعارف والاتجاهات والسلوكيات الصحية التي تم إكسابها لأطفال المجموعة التجريبية في الجلسات السابقة. ـ ؟. المناقثات التي حدثت بعد سرد كل قصة مع توضيح الدروس المستفادة بطريقة مباشرة من كل قصة ساعد على تتمية الوعي الصحي للأطفال.

وقد اتفقت نتائج هذه الدراسة مع نتائج عديد من الدراسات التي أثنتت فاعلية البرامج القصصية

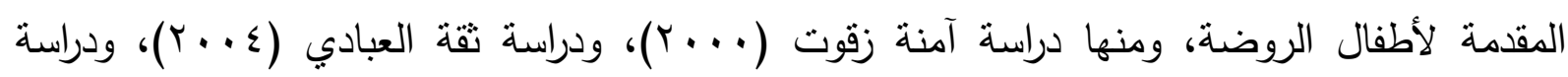

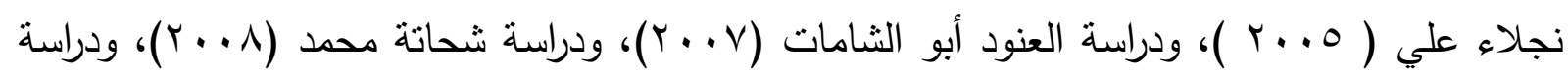

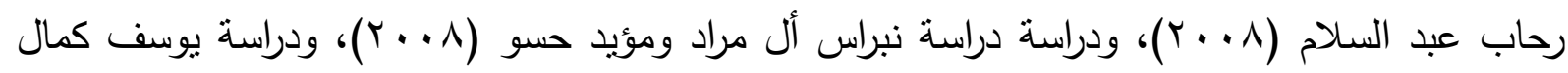

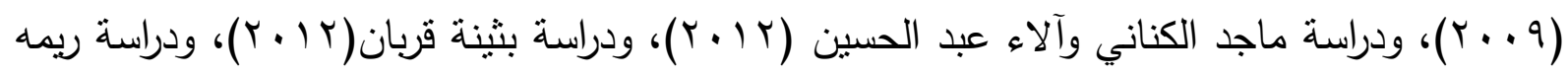

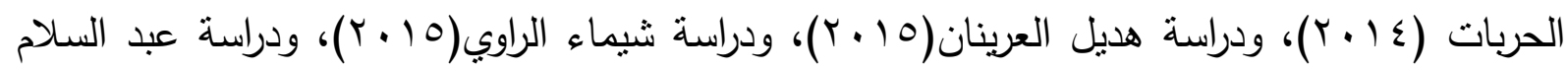

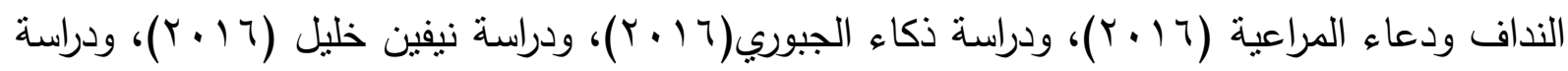

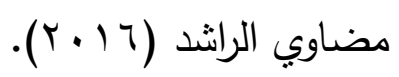

كما اتفقت نتائج هذه الدراسة مع نتائج الدراسات التي أثنتت فاعلية القصة في إكساب السلوكيات

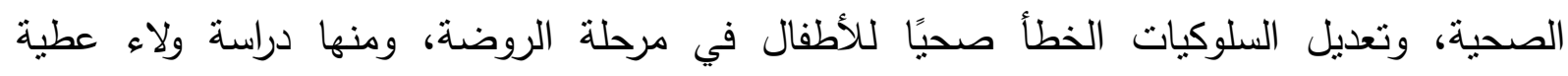

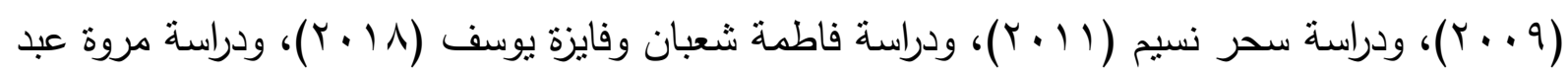

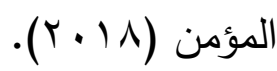

واتفقت نتائج هذه الدراسة مع نتائج الدراسات التي أثنتت فاعلية القصص مع الأطفال ذوي

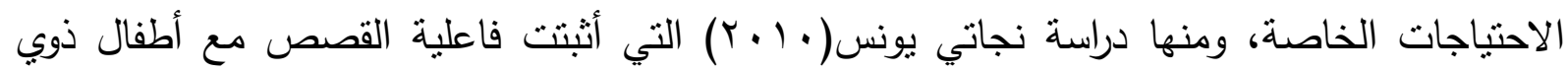
الاحتياجات الخاصة من فئات( اضطراب طيف التوحد، وذوي صعوبات التعلم، وذوبي الإعاقة العقلية)، 
كما اتفقت نتائج الدارسة الحالية مع نتائج دراسات أثنتت فاعلية القصص مع أطفال اضطراب طيف التوحد، ومنها دراسة جرايتز وآخرين (2003), Graetz et,al) ، ودراسة آدم وآخرين Adams et al,

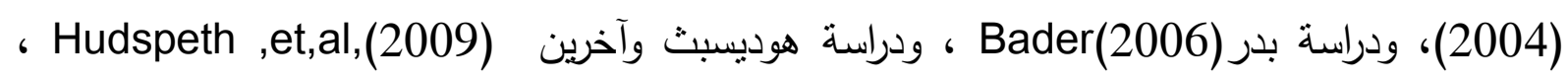

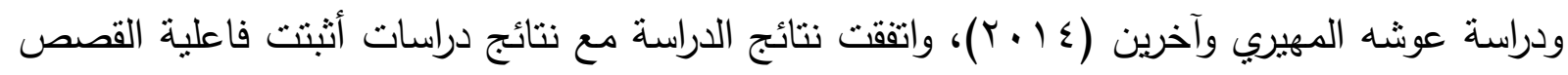
مع الأطفال ذوي صعوبات التعلم، وظهر ذلك من خلال نتائج دراسة عبد الله آل تميم ( وبـ (هـ). كما اتفقت نتائج الدراسة الحالية مع نتائج دراسات أثبتت فاعلية القصص مع الأطفال ذوي الإعاقة

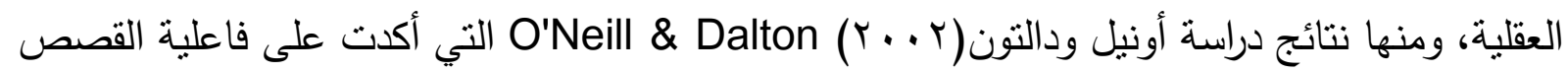
مع الأطفال ذوي الإعاقة العقلية في إكسابهح مهارات ما قبل القراءة، ودراسـة نجاتي يونس( • ( • ( التي

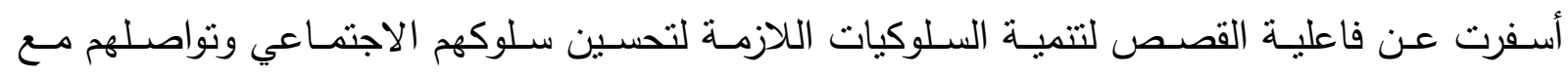
الآخرين، ودراسـة رينتتز وتيست Richter \& Test (2011) التي أثبتت فاعلية القصص في تتمية مهاراتهم الحياتية وتعديل سلوكهم ، ونتائج دراسة زياد بدوي (1 (1 ـ التي أسفرت عن فاعلية برنامج قائم على القصة لخفض سلوكهم العدواني ، ودراسة مرفت محمد (11 (1) التي أوصت بفاعلية القصص في إكسـابهم المهارات الاجتماعيـة التي يحتـاجون إليهـا في حيـاتهر، ومنهـا: (تكوين صـداقات، والتعـاون،

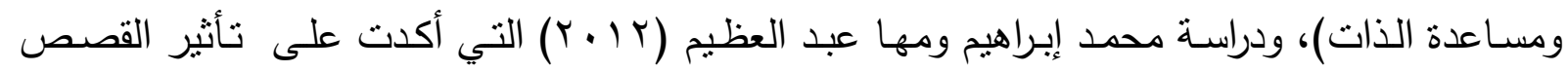
المصـورة المقدمـة مـن خـلال بـرامج التلفزيـون في تتميـة المهارات اللغويـة لهم، ودراسـة صــالح السـواح (r ( ا ( ) التي اثتتت فاعلية القصة الحركية مع الأطفال ذوي الإعاقة العقلية البسيطة لخفض اضطراب

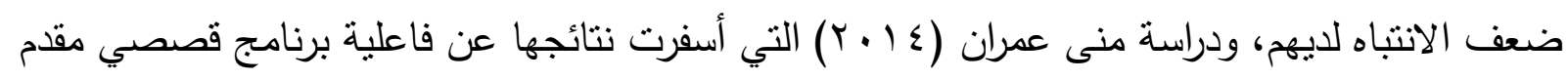

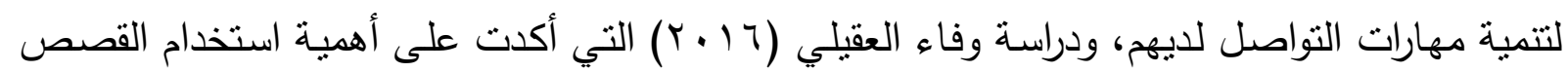
المصورة لتتمية المهارات اللغوية لديهم.

توصيات الاراسة:

في ضوء ما أسفرت عنه نتائج الدراسة، يمكن استخلاص التوصيات الآتية:

ا ـ تزويد إدارات التربية الخاصة على مستوى الجمهورية ببرنامج الدراسة؛ لعدم وجود برامج لتتمية الوعي الصحي لأطفال الروضة ذوي الإعاقة العقلية بروضات التربية الفكرية. r. عمل ورش عمل لمعلمات روضات التربية الفكرية لتوظيف البرنامج مع أطفالهم. r. عمل دورات تدريبية عن كيفية توظيف القصة مع الأطفال ذوي الاحتياجات الخاصة. ع. الاستفادة من القصة وما تتمتع به من مميزات، في توظيف القصة مع ذوي الإعاقة العقلية في جميع مراحلهم الدراسية، بالإضافة إلى توظيفها مع جميع فئات ذوي الاحتياجات الخاصة. 
0. الاهتمام بتدريس تأليف وتصميم وإنتاج القصة للأطفال العاديين وذوي الاحتياجات الخاصة، من خلال المقررات الدراسية المقدمة للطالبة المعلمة في كليات رياض الأطفال، وتربية للطفولة المبكرة. 7. ضرورة عمل دورات وورش عمل باستمرار مع ذوي الإعاقة العقلية على اختلاف أعمارهم؛ للنصح والإرشاد وتتمية الوعي الصحي لايهم. V. عمل دورات وورش عمل وعدة لقاءات مع أولياء أمور الأطفال ذوي الإعاقة العقلية؛ لتقديم طرق تتمية الوعي الصحي لدى أطفالهم. ^. ضرورة التزام المعلمات الروضات بممارسة السلوك الصحي أمام الأطفال. 9. استغلال وسائل الإعلام المرئية ( كالتلفزيون والسنيما والمسرح ) بتوفير برامج لتتمية الوعي صحي للأطفال. • ا ـ توفير داخل روضات ومدارس التزبية الخاصة الاسعافات الأولية في حالة الطوارئ إذا تعرض أي طفل للحوادث والمخاطر . 1 ا ـ توفير أوقات مخصصة بالأندية ومراكز الثباب لممارسة ذوي الاحنياجات الخاصة بجميع فئاتها الأنشطة البدنية والرياضية، واكتشاف الموهوبين منهم والأبطال، وتوجيههم للاشتراك في المسابقات المحلية والدولية. ץ ا. الكثف الدوري على الأطفال من قبل طبيب الروضة، والتحويل للوحدات الصحية إذا لزم الأمر، والسماح للأطفال بالإجازات المرضية، كما يجب متابعة كل طفل للتأكد من شفائه، وعدم وصوله لمرحلة نقل العدوى لمن حوله من الأطفال. با. السماح بالحصول على إجازة مرضية لأي فرد يعمل داخل الروضة أو المدرسة في حالة احتباجه لذلك.

ع ا ـ ضرورة توفير معايير البيئة الصحية لجميع المؤسسات التربوية منذ مرحلة الروضة إلى مرحلة الجامعية، دن خلال توفير المعايير الصحية للمباني، والتجهيزات الخاصة بها وملحقاتها، ومرافقها، والمواردها المائية، ودورات المياه التي توجد بها، والمطاعم إن وجدت. 1 ـ تفعيل الاحتفال بيوم الصحة العالمي الموافق V من شهر أبريل من كل عام، وعمل دوردات واحتفالات وورش عمل خاصة لتتمية الوعي الصحي بين الأطفال المدمجين الملتحقين بالروضات والمدارس العادية، والأطفال الملتحقين بروضات ومدارس التربية الخاصة لرفع الوعي الصحي لديهم.

7 ا. تفعيل الاحتفال باليوم العالمي لغسل اليدين GHD ) Global Handwashing Day ) الموافق 10 أكتوبر من كل عام في جميع الروضات والمدارس، وهو يدعو إلى نظافة وتطهير 
اليد باستمرار بالماء والصابون، ويهدف إلى رفع الوعي الصحي بنظافة اليدين، باعتبارهما أساس انتقال الأمراض، ولذلك يجب الحفاظ على على نظافتهما باستمرار .

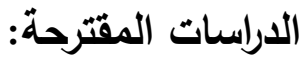

- برنامج قائم على الوسائط المتعددة لتتمية الوعي الصحي لدى أولياء أمور الأطفال ذوي

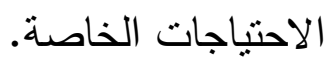
- معايير تصميم القصص المقدمة لأطفال الروضة المكفوفين.

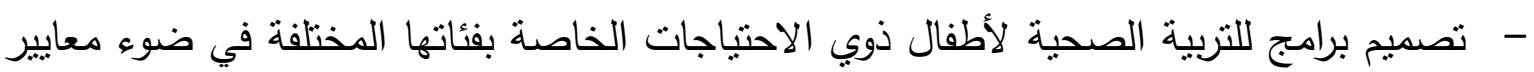
التربية الصحية العالمية . - - برنامج قائم على القصة لتتمية المفاهيم العلمية لدى الأطفال الموهوبين.

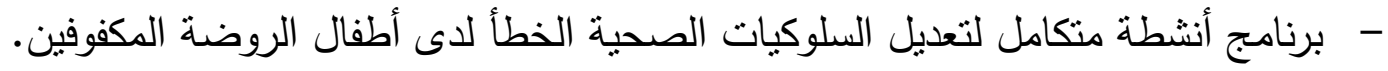
- دراسة لتحديد معايير الروضة الصحية النموذجية لكل فئة من فئات التربية الخاصة.

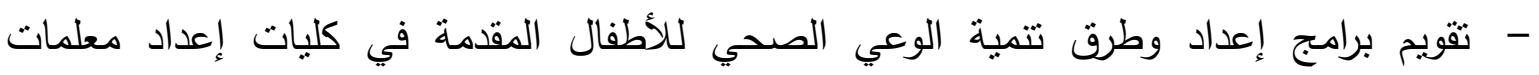

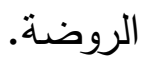




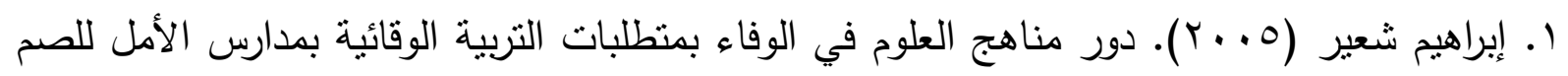

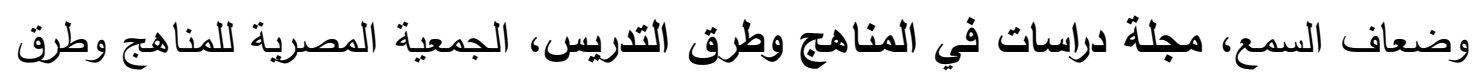

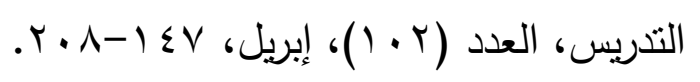

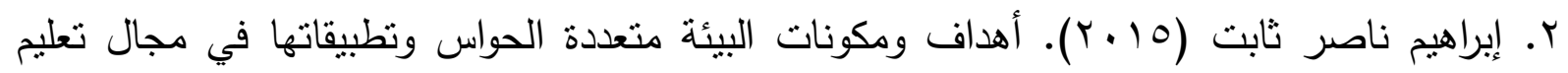

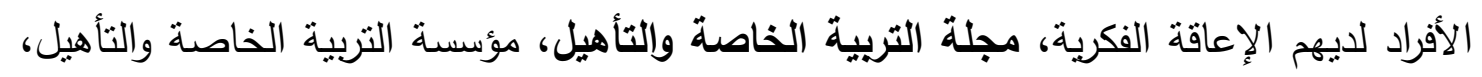

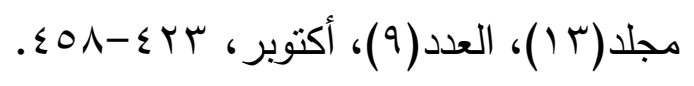

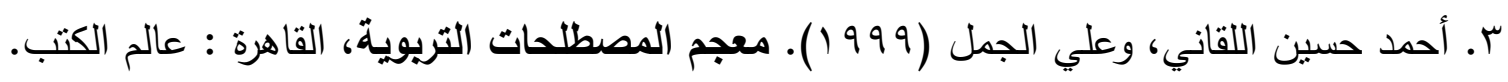

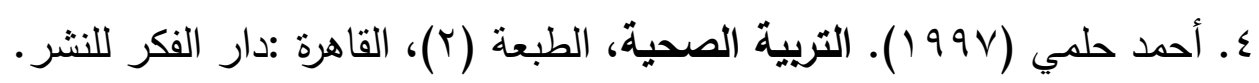

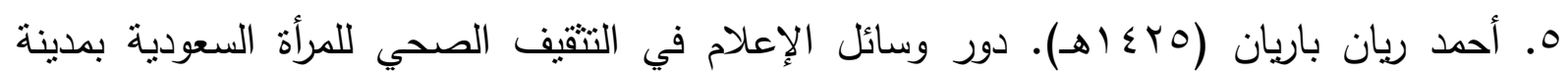

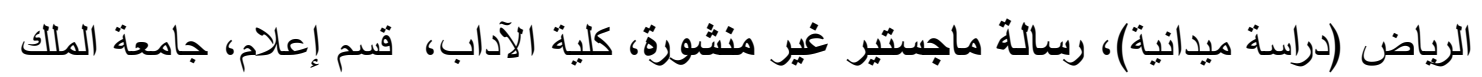

$$
\text { سعود. }
$$

7.أحمد سلامة (1991). تنمية الوعي الصحي لاى طلاب المرحلة الثانوية في دول الخليج، الرياض :

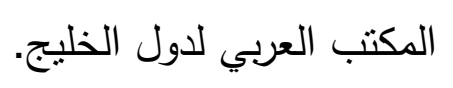

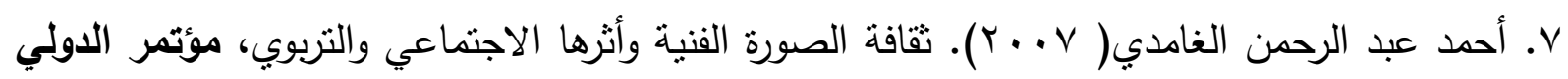

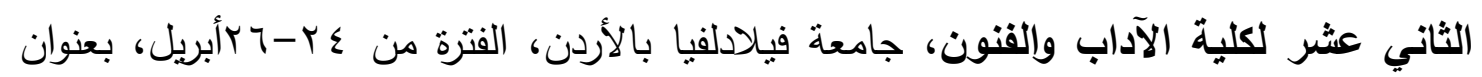

$$
\text { "ثقافة الصورة" }
$$

Retrieved Mars, 2017 from :

https://www.philadelphia.edu.jo/arts/12th/abstract1.htm

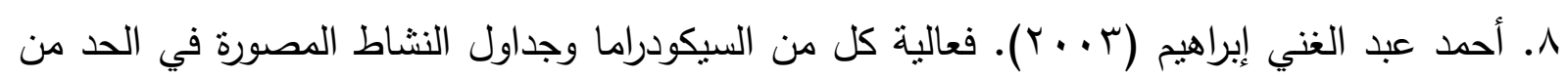

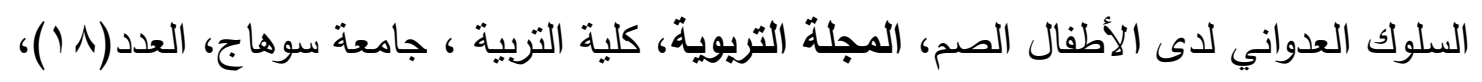

$$
\text { r.r-IVT }
$$

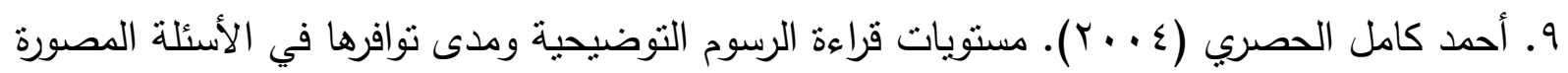

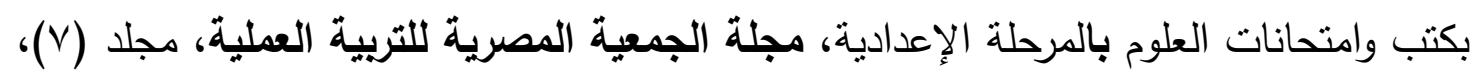

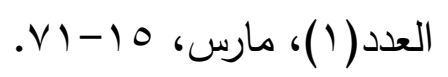

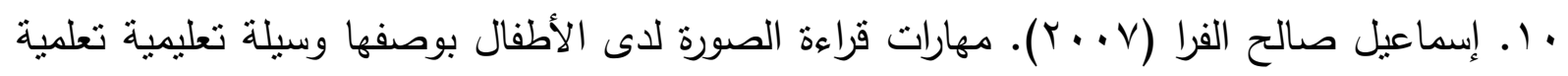

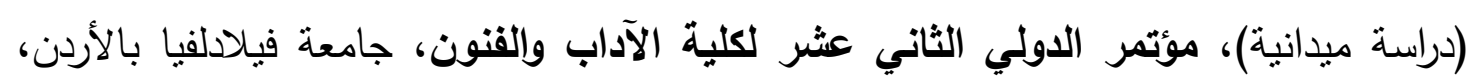

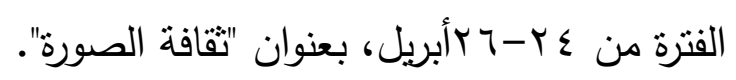

Retrieved December, https://www.philadelphia.edu.jo/arts/12th/abstract1.htm 2016 from : 
ا ا. إكرام حمودة الجندي (1 . . r). تتمية الوعي الصحي لأطفال ما قبل المدرسة في ضوء معايير

التربية الصحية، رسالة دكتوراه غير منشورة، قسم رياض الأطفال، كلية التربية، جامعة طنطا.

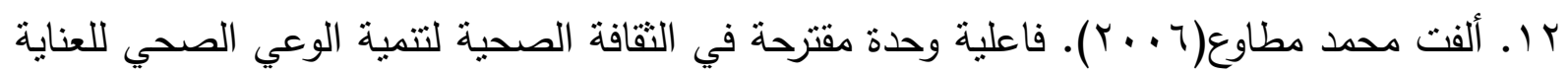
بالفم والأسنان لدى تلاميذ الصف الرابع الابتدائي، المؤتمر العلمي العاشر للجمعية المصرية

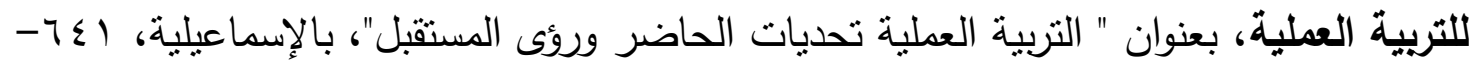

r ا. آمال محمد (0 . . ץ). فعالية برنامج مقترح قائم على جداول النشاط المصورة والمكتوبة في تتمية بعض المهارات اللازمة للصحة والسلامة لدى المتخلفين عقليًا القابلين للتعلم، المؤتمر العلمي للجمعية المصرية للتربية العملية التاسع بالإسماعيلية، بعنوان" معوفات التربية العملية في

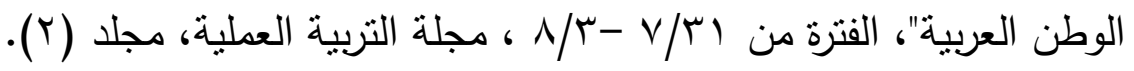
ع ا ـ أمل خلف (T . . ץ) ـ قصص الأطفال وفن روايتها، القاهرة : عالم الكتب.

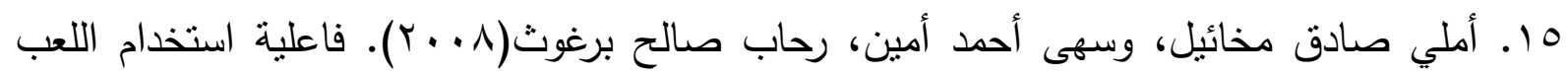
التمثيلي في تتمية مهارات الأمان للأطفال المتخلفين عقليًا، المؤتمر الدولي الأول لكلية رياض رئرة

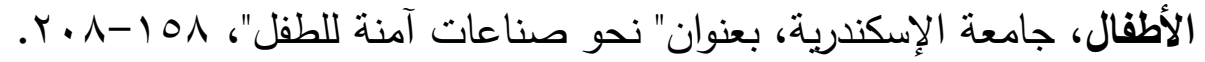
ד ا. آمنة زقوت ( . . . ب). مدى تأثثر قصص الأطفال المحكية على تعديل السلوك العدواني لدى طفل الروضة، رسالة دكتوراه غير منشورة، كلية التربية، جامعة عين شمس.

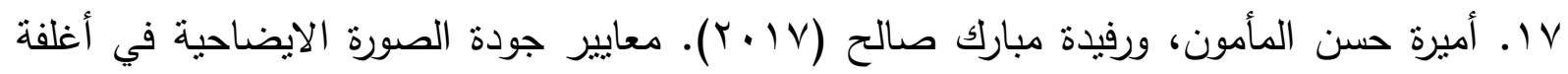
الكتب المدرسية "كتب اللغة العربية مرحلة الأساس الحلقة الأولى"، مجلة العلوم الإنساتية،

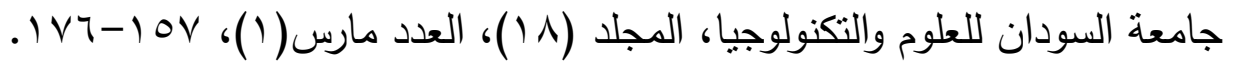
1 ا. أميرة عبد الحميد حسن الجابري (T ( . ؟). العلاقة بين كثافة العناصر في الرسومات التوضيحية وخلفياتها ونمو الإدراك البصري للمفاهيم البيئية لدى أطفال ما قبل المدرسة، رسالة ماجستير غير منشورة، قسم تكنولوجيا التعليم، كلية التربية، جامعة حلوان.

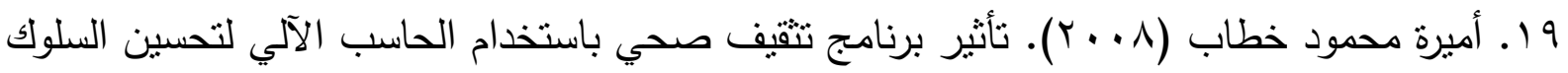
الصحي لأطفال مؤسسة (SOS) للأيتام بالغربية، رسالة ماجستير غير منشورة، كلية التربية، جامعة طنطا.

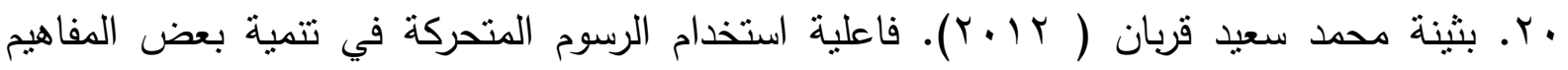
العلمية والقيم الاجتماعية لأطفال الروضة في مدينة مكة المكرمة، رسالة دكتوراه غير منشورة، قسم المناهج وطرق التدريس، كلية التربية ، جامعة أم القرى.

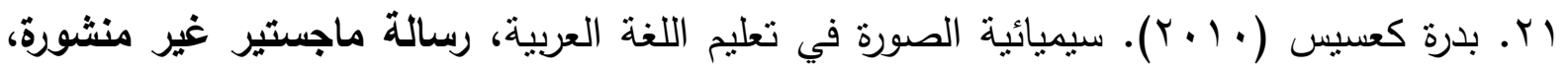
قسم اللغة العربية وآدابها، كلية الآداب والعلوم الاجتماعية، جامعة فرحات عباس (سطيف) - الجزائر 


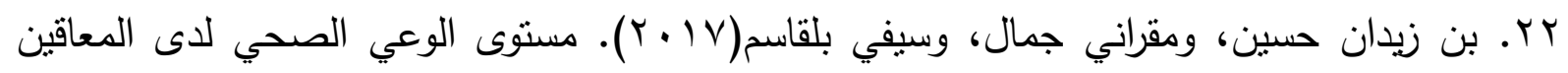

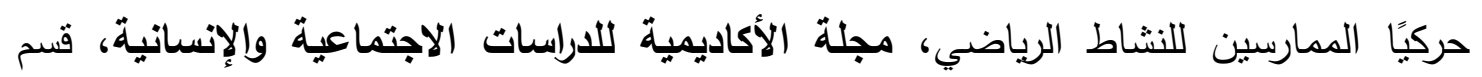

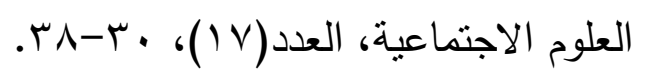

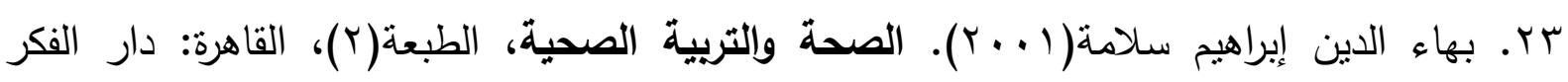

$$
\text { العربي. }
$$

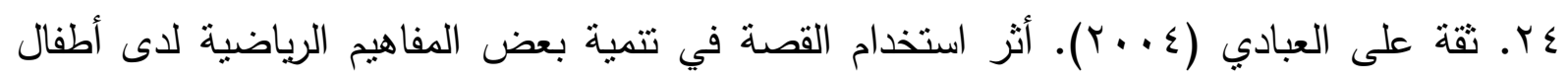

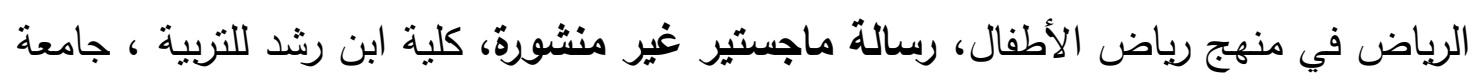

$$
\text { بغداد. }
$$

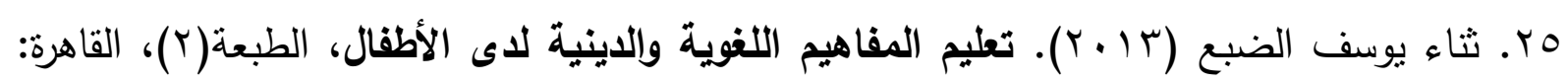

$$
\text { دار الفكر العربي. }
$$

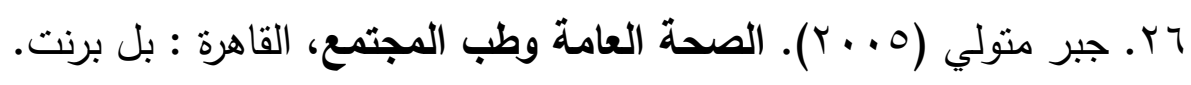

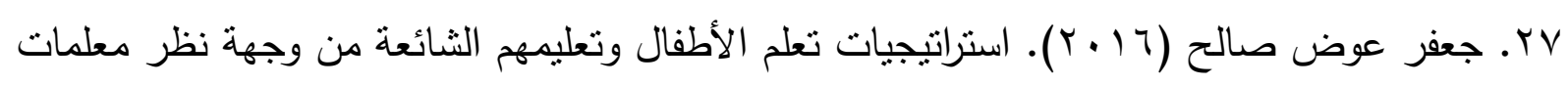

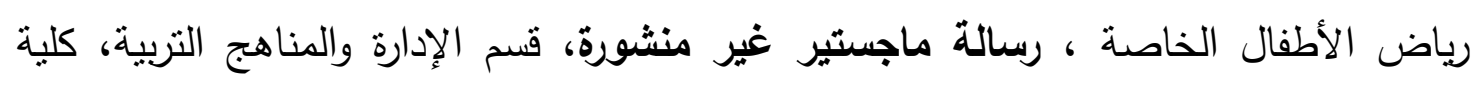

$$
\text { العلوم التربوية، جامعة الثرق الأوسط. }
$$

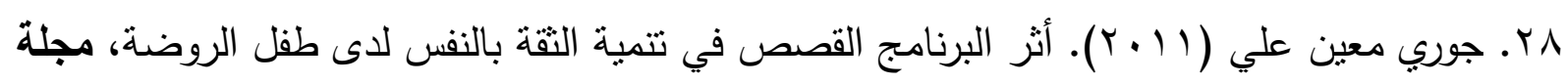

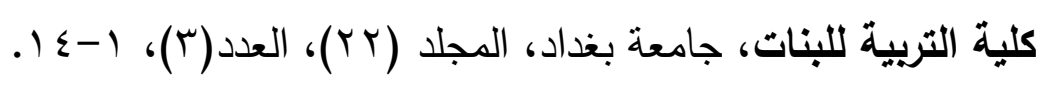

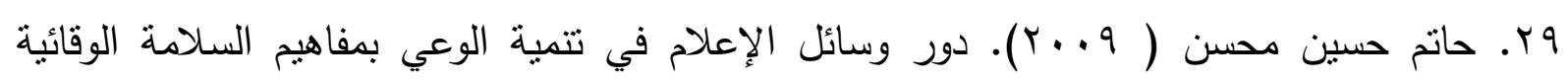

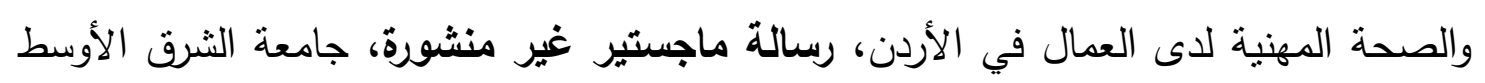

$$
\text { للاراسات العليا، الأردن. }
$$

• r. حسن شحاتة (1991). أدب الطفل العربي (دراسات ويحوث). القاهرة: الدار الدصرية اللبنانية.

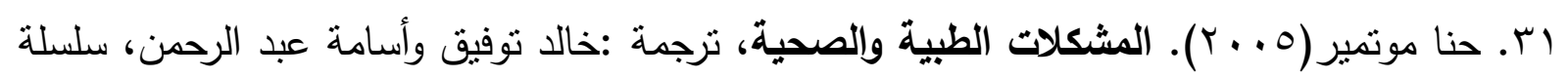

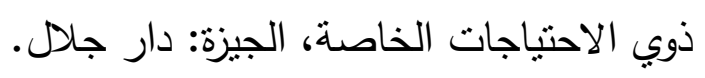

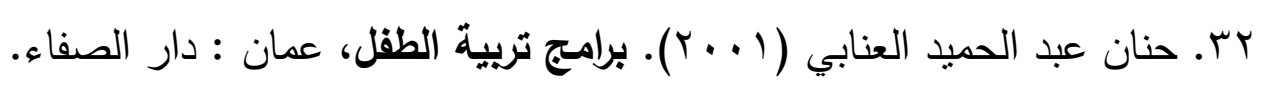

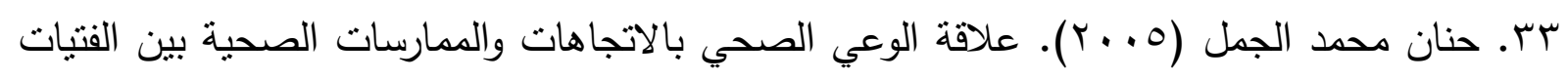

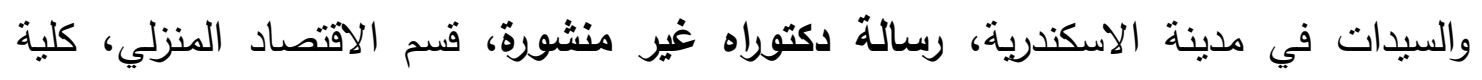

$$
\text { الزراعة، جامعة الإسكندرية. }
$$

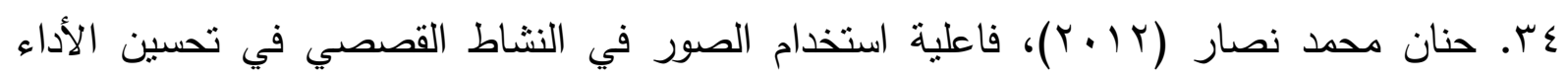

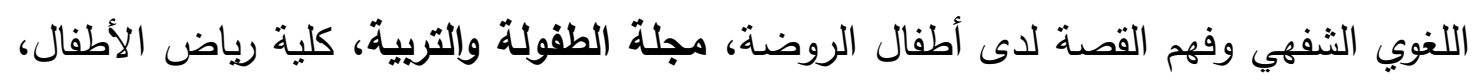

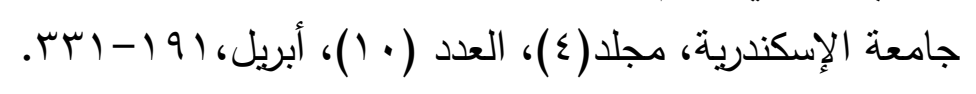

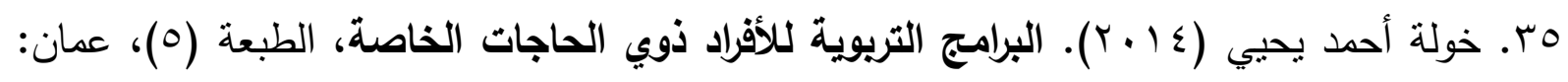
دار المسيرة. 


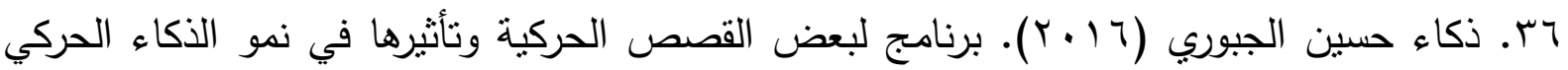

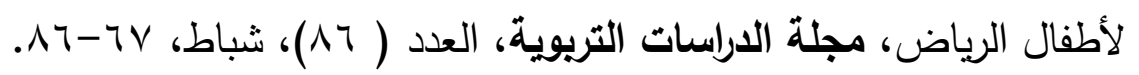

V. ذكي محمد حسن (ع . . ץ). التنشئة الصحية الرياضية من الطفولة إلى المراهقة، الاسكندرية: المكتبة المصرية.

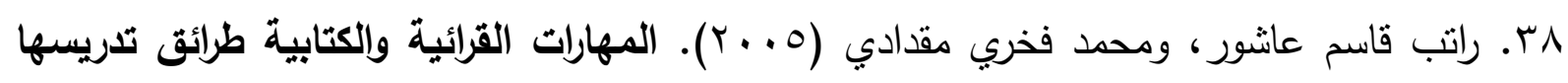
واستراتيجياتها، عمان : دار المسيرة.

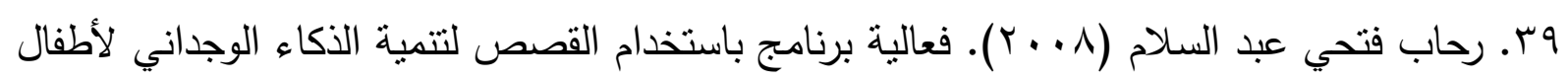
الروضة، رسالة دكتوراه غير منشورة، معهد الدراسات العليا للطفولة، جامعة عين شمس.

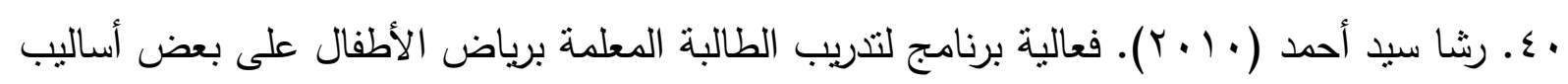
تقديم وتقويم قصص وحكايات الأطفال، رسالة دكتوراه غير منشورة، جامعة القاهرة. (ي. رشا محمد علي ( 999 (1). مدى فاعلية برنامج إرشادي لخفض حدة الاضطرابات السلوكية لدى ولى الأطفال المعاقين عقليًا من فئة القابلين للتعليم، رسالة ماجستير غير منشورة، معهد الدراسات إنياتئ العليا للطفولة، قسم الدراسات النفسية والاجتماعية، جامعة عين شمس.

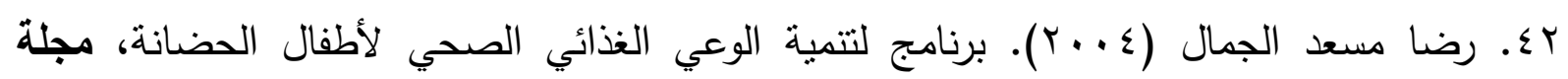

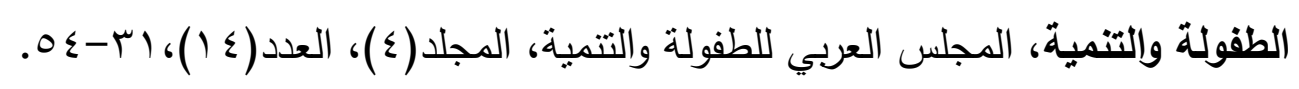

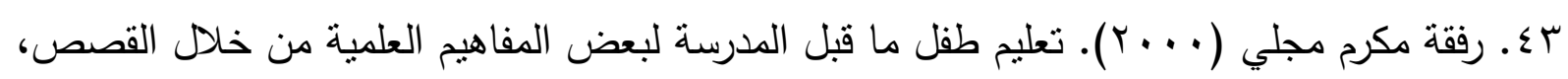
رسالة ماجستير غير منشورة ، قسم علم النفس التربوي، كلية التربية، جامعة حلوان. ــ. رقية السيد العباس (ع . . ץ). تطبيث برنامج التربية الصحية على الأطفال المعاقين عقليًا بولاية الخرطوم، مجلة الدراسات التربوية العدد( (1).

Retrieved June, 2017 from:

https://www.researchgate.net/...Elsayed2/...application...health 0ـ. روبرت سولسو ( . . . . . علم النفس المعرفي ، ترجمة : محمد نجيب الصبوة ومصطفى محمد

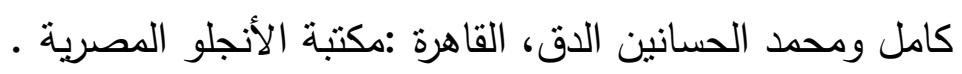

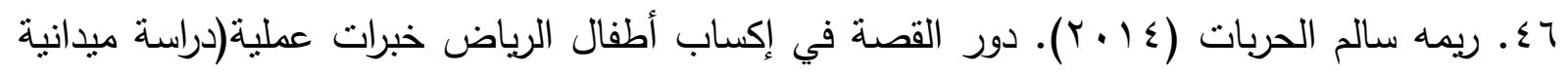

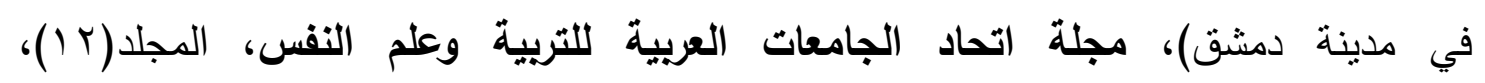

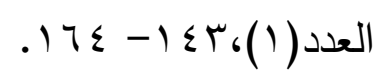

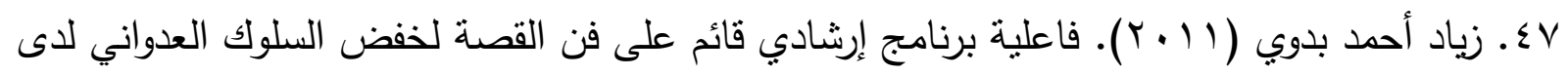

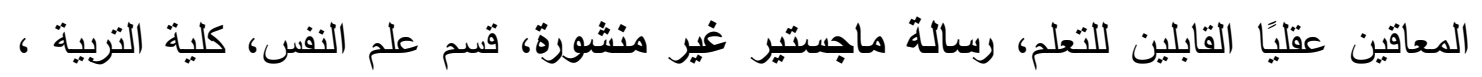
عمادة الدراسات العليا، الجماعة الإسلامية-غزة. 
^ــ. زينب محمد عبد المنعم، وإيمان عبد الله شرف (11 • (r). فاعلية مسرح الطفل في إكساب طفل

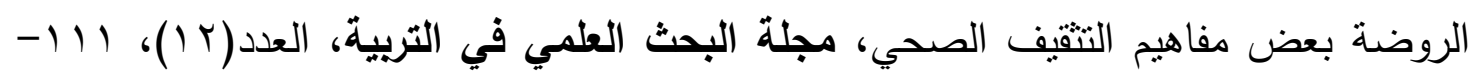
$.1 \mathrm{~V}$.

9. سحر توفيق نسيم(1) ( (Y). فعالية برنامج مقترح يبسط فكرة عمل بعض الأجهزة الكهربية لطفل الروضة وينمي سلوكيات الأمان والسلامة لديه واتجاهه نحو تقدير جهود العلماء، مجلة الطفولة

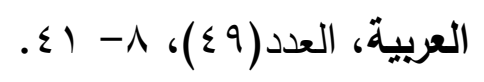

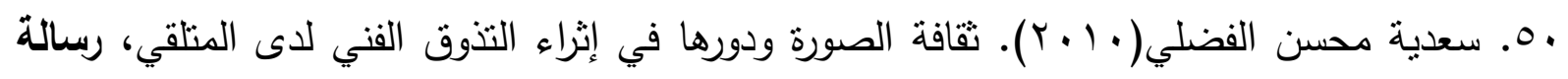
ماجستير غير منشورة، قسم التربية الفنية، كلية التربية ، جامعة أم القرى.

1. سعيد حسني العزة( ( . ب). الإعاقة السمعية واضطرابات الكلام والنطق واللغة، عمان : الدار العلمبة الدولة.

ro. سمير عبد الوهاب أحمد (9 . . ץ). أدب الأطفال( قراعات نظرية ونماذج تطبيقية)، الطبعة(r)، عمان: دار المسيرة.

ror سمير محمد عقل ، وقيس نعيم سليم عصفور(0 (10). فاعلية برنامج مقترح في العلوم قائم على التعليم المعزز بالحاسوب في التحصيل الأكاديمي وتتمية المهار ات الحياتية و الوعي الصحي لدى المعاقين عقليًا القابلين للتعلم بالمرحلة المتوسطة، مجلة كلية التربية، جامعة سو هاج، العدد(ب ع ) • أكتوبر

Retrieved April, 2017 from : http://www.eulc.edu.eg/eulc ـ. سمير يونس صلاح (Y . . r). أثز برنامج قائم على القصة في تتمية بعض مهارات القراءة الإبداعية لدى تلاميذ المرحلة الابتدائية ، مجلة دراسات في المناهج وطرق التدريس، الجمعية

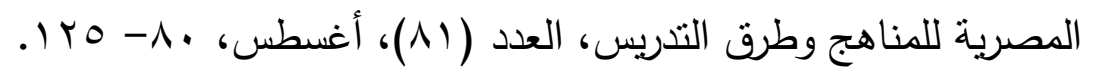

00. سناء الخولي (^ . . ب). الأسرة والحياة العائلية، الإسكندرية : دار المعرفة الجامعية.

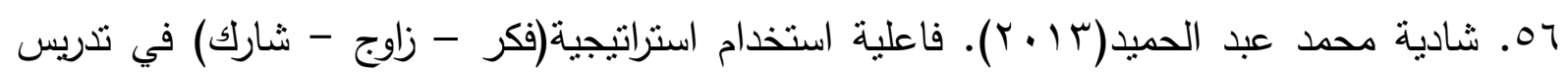
منهج رياض الأطفال المطور على تتمية الوعي الصحي وبعض مهارات التواصل الثفوي لدى طفل الروضة، رسالة ماجستير غير منشورة، كلية التربية، جامعة سوهاج.

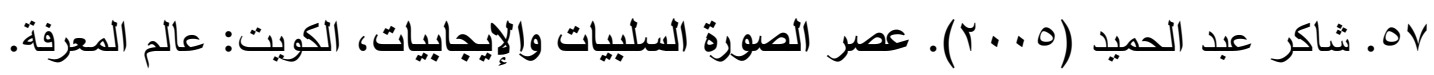
هـ شحاتة سليمان محمد(^ . ㄷ). فاعلية برنامج قصصي لتتمية القيم الأخلاقية والاجتماعية لطفل

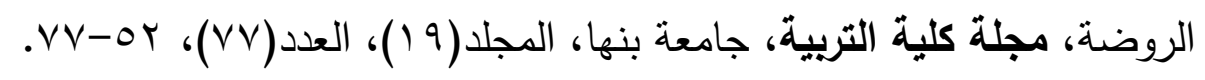

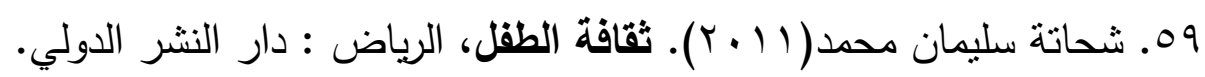

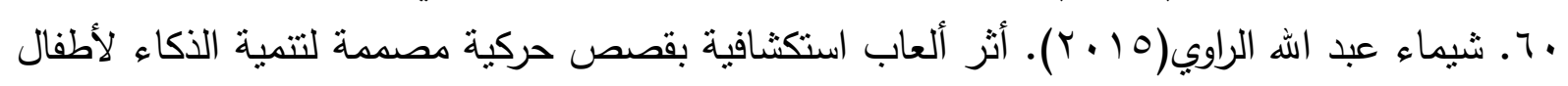

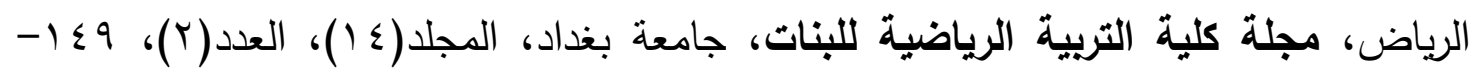




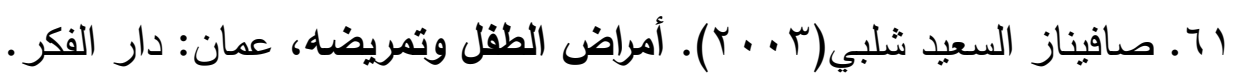

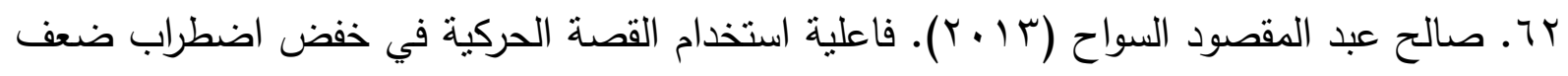
الانتباه لدى المعاقين عقليًا القابلين للتعلم ، مجلة دراسات تريوية ونفسية، كلية التربية، جامعة

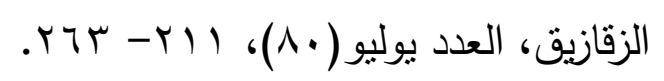

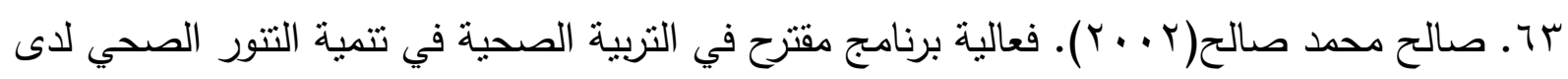

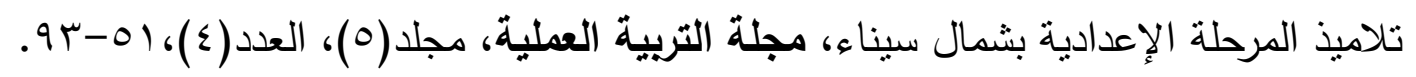

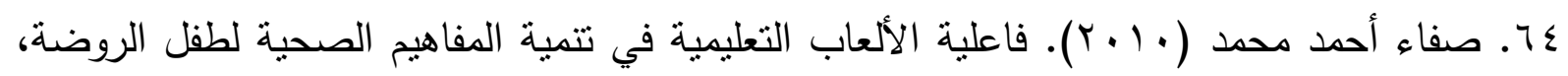
مجلة دراسات عربية في التربية وعلم النفس ( ASEP )، المجلد(ع)، العدد(ع)، 109 1: V.r.

ه7. صفوت فرج (11 + (Y). اختبار ستانفورد بينيه الصورة الخامسة، القاهرة: الأنجلو المصرية. דا. صلاح الدين عبود، وسحر عبود (r...r). دراسة لمفهوم الذات لدى الأطفال الصم وعلاقته

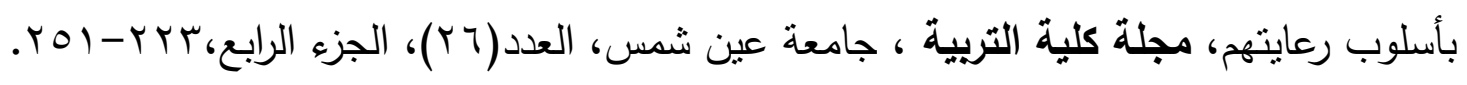

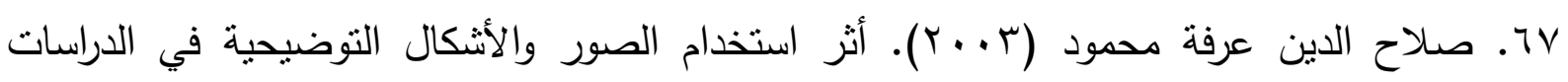
الاجتماعية لتمية عمليات التفكير لدى تلاميذ الصف الرابع والخامس الابتدائي وميولهم نحو

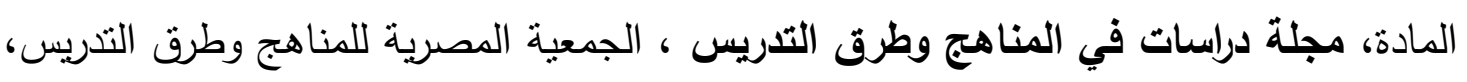

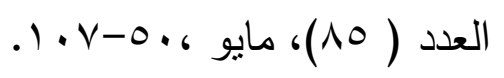

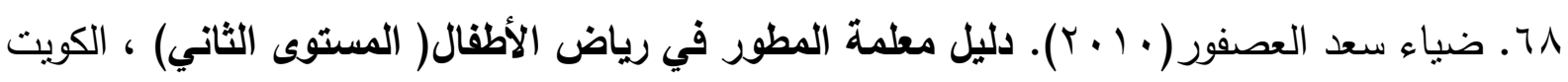
: وزارة التربية .

Retrieved May, 2017 from : https://eltsupervision.files.wordpress.com

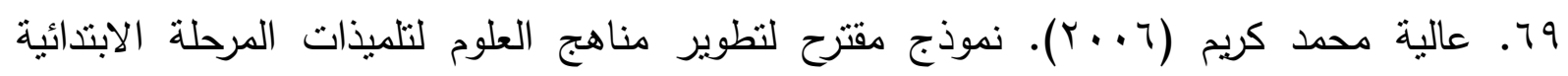
للمعاقات سمعيًا على ضوء مجالات التربية الوقائية وأبعادها، رسالة دكتوراه غير منشورة، كلية

$$
\text { التربية ، جامعة الملك سعود. }
$$

• V. عامر محمد الأميري، وضحى عادل العاني، وهبة سلام مهدي(ع ا ـ ب). أثز التصحيح الزائد في تعديل بعض العادات الغذائية غير السليمة لدى الأطفال المصابين بسوء التغذية ، مجلة البحوث

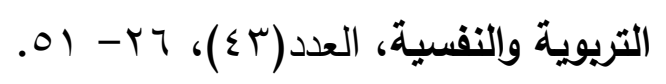

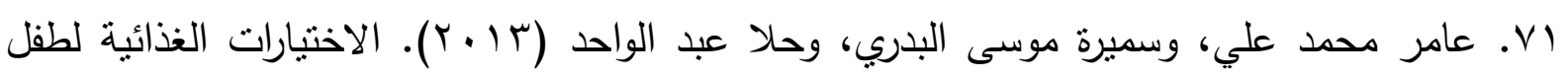
الروضة وعلاقتها بالدخل الثهري للأسرة، مجلة كلية التربية للبنات، جامعة بغداد،

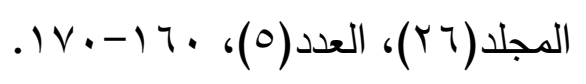

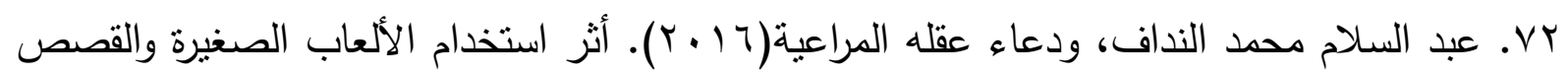
الحركية على تتمية بعض عادات العقل لدى طلبة رياض الأطفال، مؤتمر كلية التربية الحادي

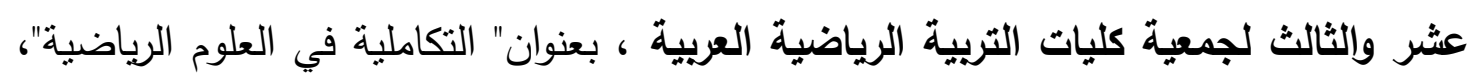

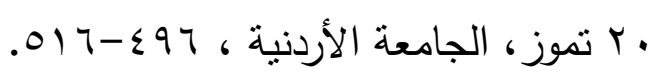




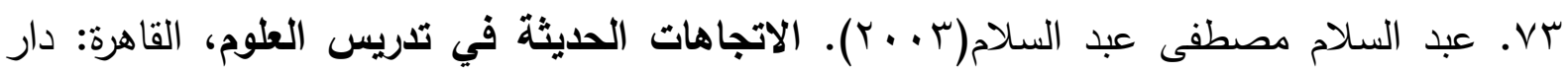
الفكر العربي.

ع V. عبد العظيم العطواني(ع . . ب). تربية الأطفال المعوقين سمعيًا في ضوء مبدأ تكافؤ الفرص التربوية، المؤتمر العلمي الثاني، بعنوان" تربية الأطفال ذوي الاحتياجات الخاصة في الوطن العربي الواقع

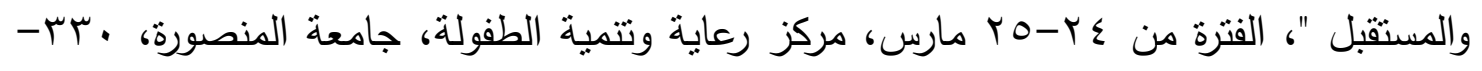

. \&. O

ه v. عبد العظيم عبد السلام الفرجاني(r . . r). تكنولوجيا إنتاج المواد التعليمية، القاهرة: دار غريب.

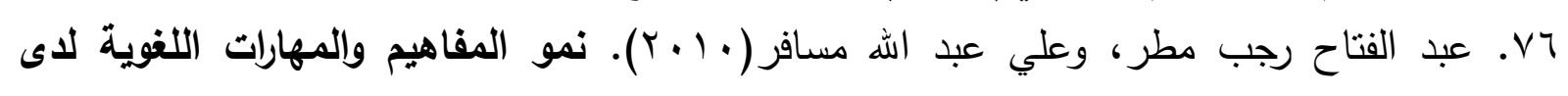

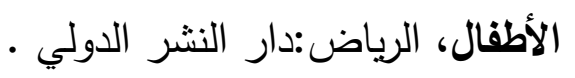

VV التلميذ للسنة الأولى من التعليم الابتدائي نموذجًا)، مجلة الدراسات والبحوث الاجتماعية، جامعة

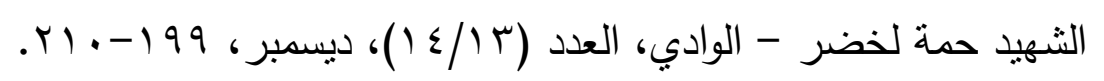

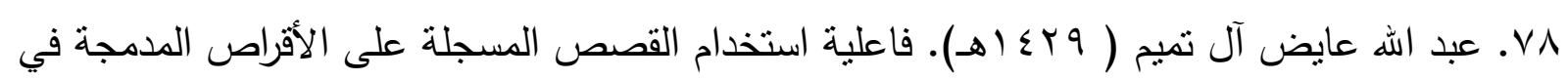
علاج صعوبات القراءة لدى تلاميذ الصف الثالث الابتدائي، رسالة ماجستير غير منشورة، قسم المناهج وطرق التدريس، كلية التربية ، جامعة أم القرى.

و V. عبد المحي محمود صالح( ( . . ץ). الصحة العامة وصحة المجتمع الأبعاد الاجتماعية والثثافية، الإسكندرية: دار المعرفة الجامعية.

• ^. عبد المعين سالم هندي (1 ( . ب). دور التعليم في تتمية الوعي الصحي لدى مرضى السكر (دراسة ميدانية)، مجلة البحث في التربية وعلم التفس، كلية التربية ، جامعة المنيا، العدد(ب)،

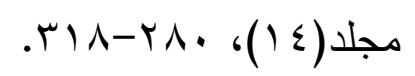

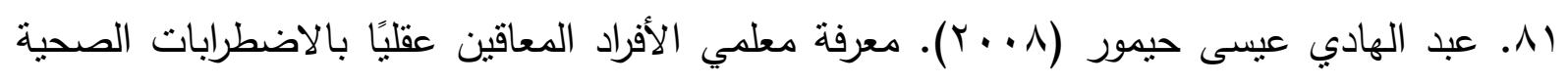
التي يعاني منها هؤلاء وأثر برنامج تدربيي في تتميتها، رسالة دكتوراه غير منشورة ، قسم التربية الخاصة ، كلية الدراسات العليا، الجامعة الأردنية.

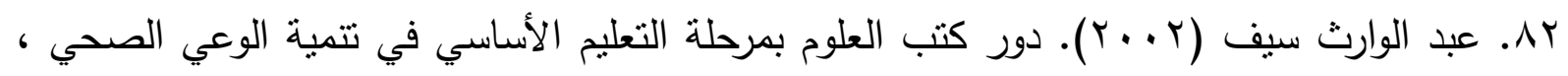
مجلة دراسات في المناهج وطرق التدريس، الجمعية المصرية للمناهج وطرق التدريس، العدد $.1 \cdot 9-\lambda \vee \cdot(\vee \Lambda)$

r^. عثمان لبيب فراج (ץ . . ץ). الإعاقة الذهنية في مرحلة الطقولة ، القاهرة : المجلس العربي للطفولة والتتمية . مانية

ــ. عصام الصفدي، ومروان أبو حويج، وعادل العماد (1 (. ب). العادات السلوكية والاجتماعية والتربية الصحية، عمان : دار المسيرة. 


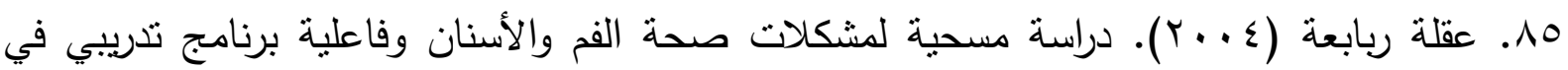
تحسين صحة الفم والأسنان لاى الأشخاص المعاقين إعاقة عقلية بسيطة في الأردن، رسالة

\section{دكتوراه غير منشورة ، جامعة عمان العربية ، الأردن •}

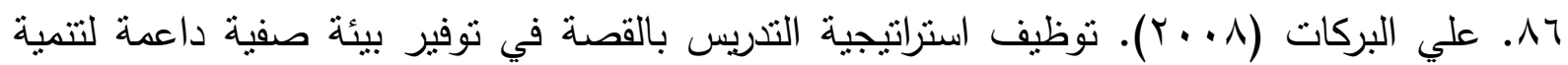

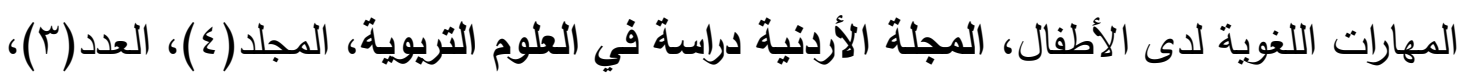

$$
. r \cdot r-1 \wedge 9
$$

AV

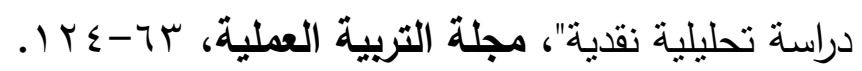

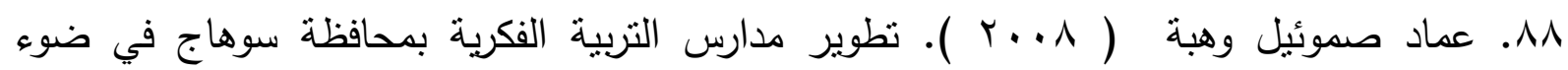

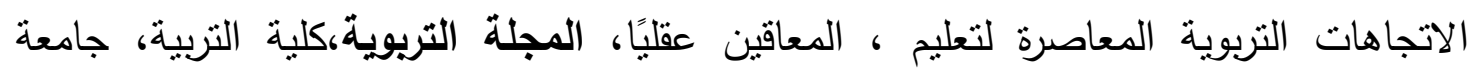

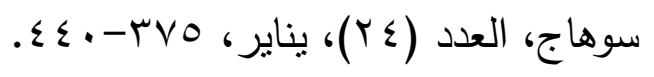

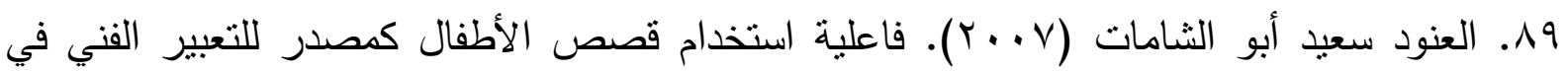

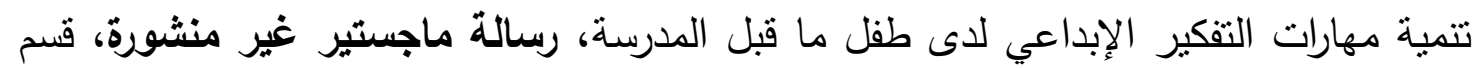

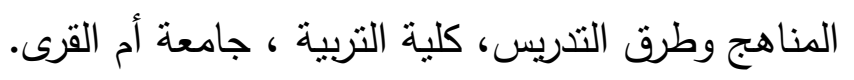

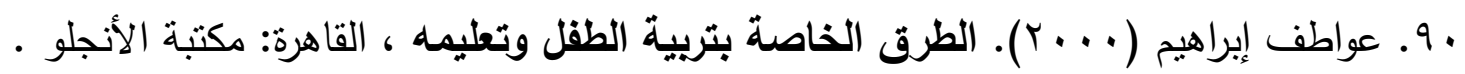

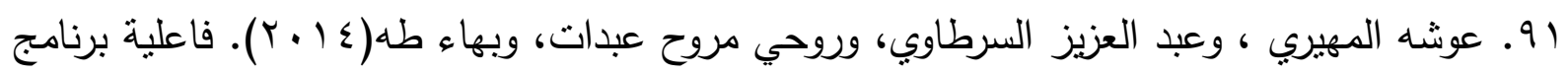

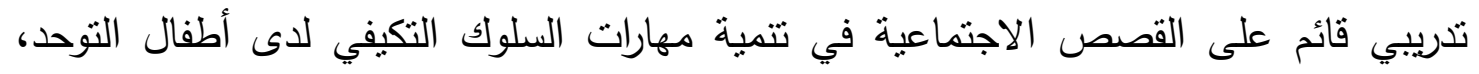

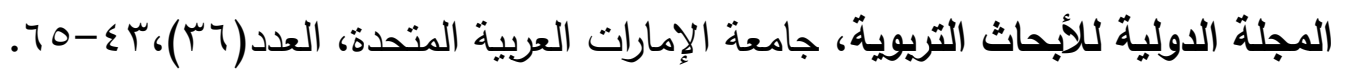

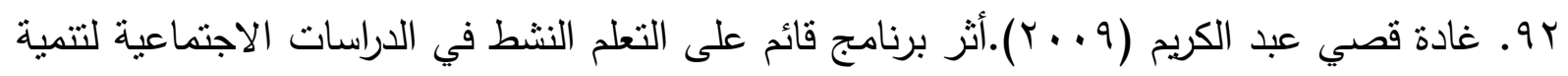

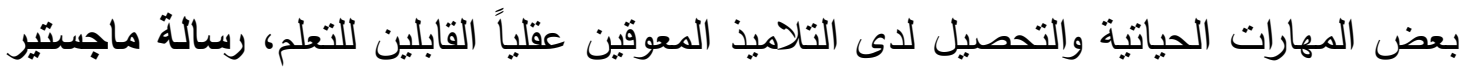

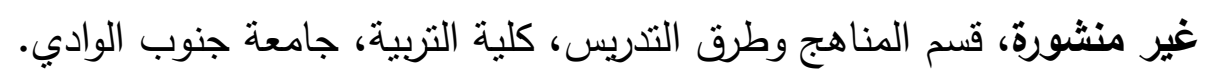

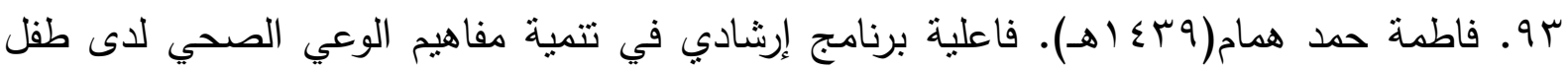

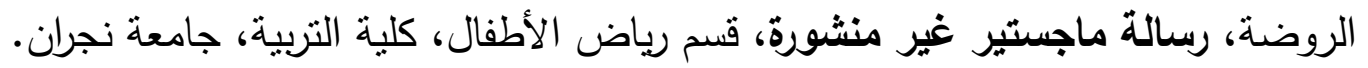

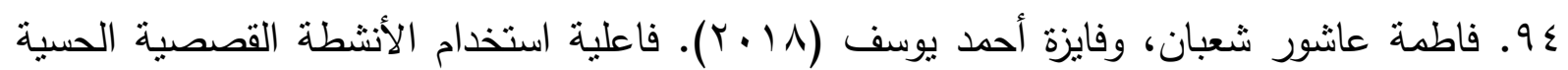

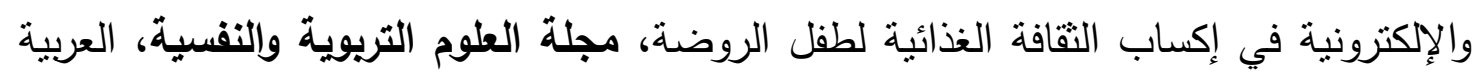

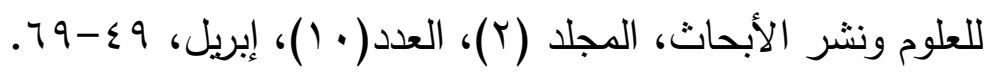

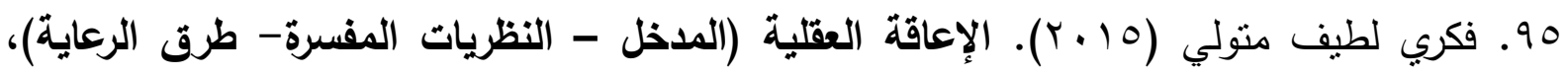

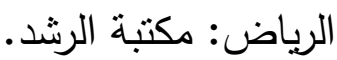

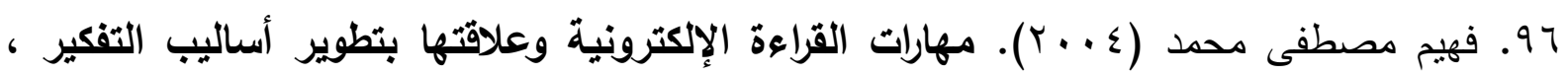

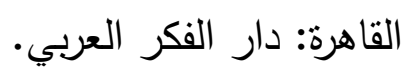




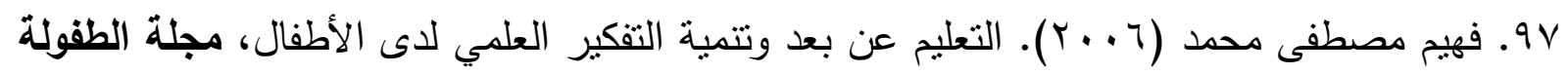

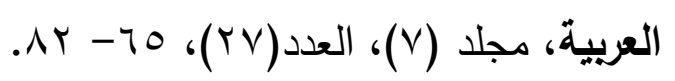

19. كمال إبراهيم مرسي (799 (99) ). مرجع في علم التخلف العقلي، الكويت : دار القلم.

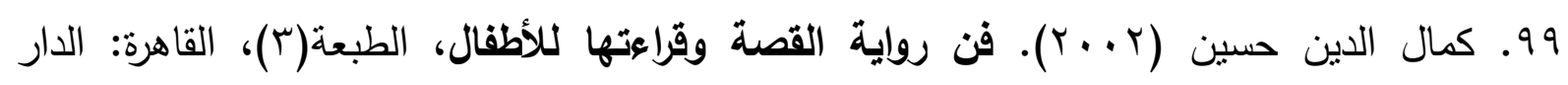
المصرية اللبنانية.

. . . . كمال الدين حسين (ع . . r). أدب الأطفال، الإسكندرية : مركز الإسكندرية للكتاب. 1. 1. كمال الدين حسين (T . . r). مدخل في قصص وحكايات الأطقال، الإسكندرية : مركز الإسكندرية للكتاب.

ץ. 1. كمال زبتون (r . ..r). تكنولوجيا التعليم في عصر المعلومات والاتصالات ، القاهرة : عالم الكتب

r.1. ليلى كرم الدين (ع . . (ץ). الاتجاهات الحديثة في رعاية وتتقيف الأطفال ذوي الاحتياجات الخاصة، المؤتمر العلمي الثاني لمركز رعاية وتنمية الطقولة، بعنوان " تربية الأطفال ذوي

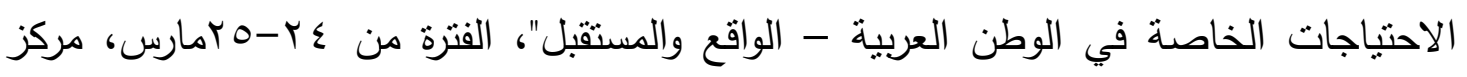

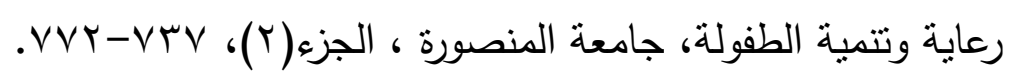

ـ. 1. ماجد نافع الكناني، وآلاء رضا عبد الحسين (Y ( • (Y). فاعلية القصة الكارتونية لتتمية التعبير

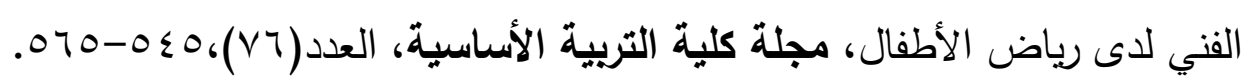
0. 1 ـ مارجوت صاندرلاند (0 . . ؟). علاج الأطفال بالقصة، القاهرة: دار الفاروق.

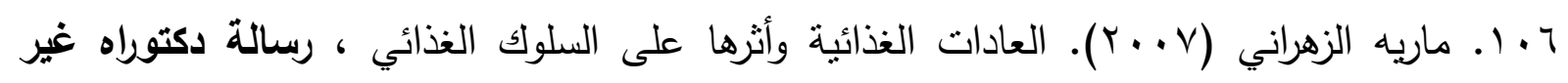
منشورة ، كلية الاقتصاد المنزلي، قسم التغذية وعلوم الأطعمة، جامعة أم القرى.

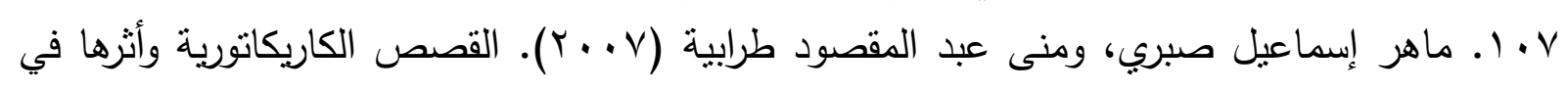
تعديل أنماط السلوك غير الصحي وتتمية الوعي به لدى الأطفال المعاقين سمعيًا، مجلة دراسات

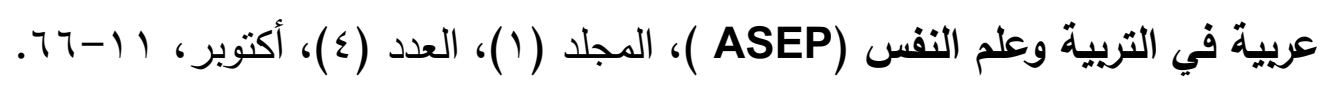

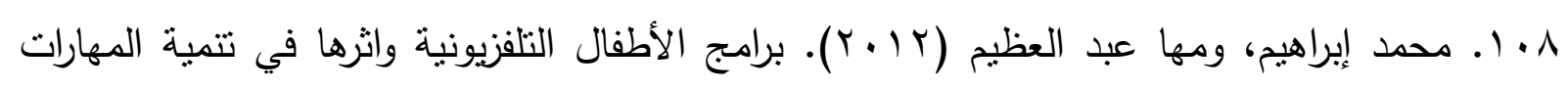

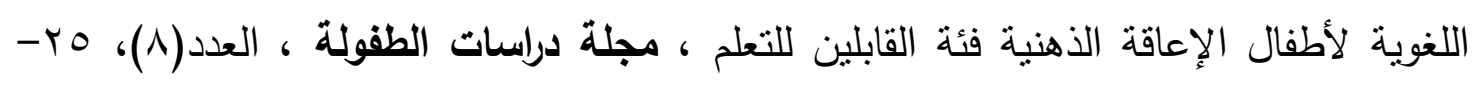

Mr

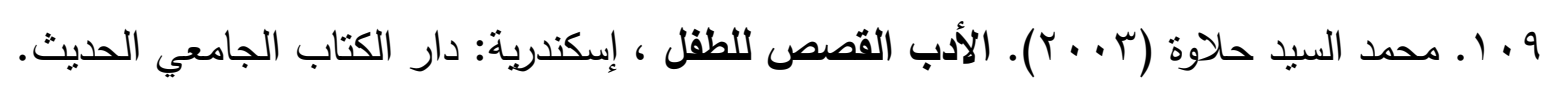

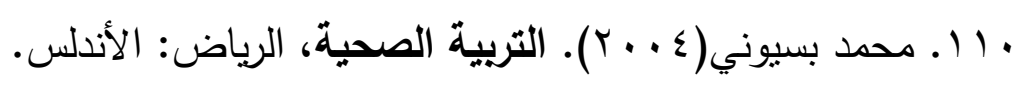

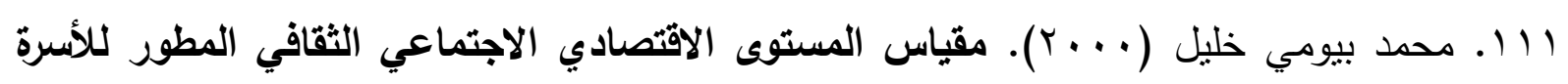

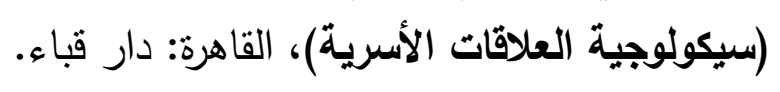

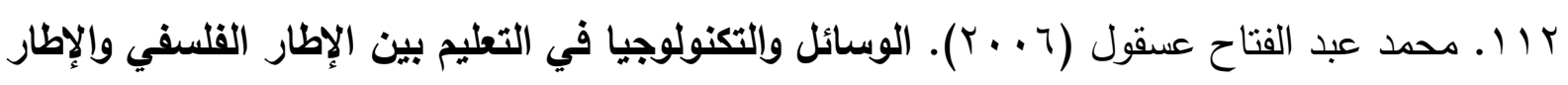
التطبيقي، الطبعة (Y)، غزة: دار غزة. 


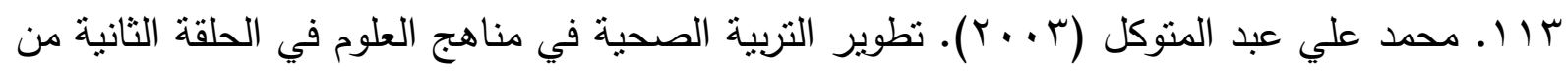

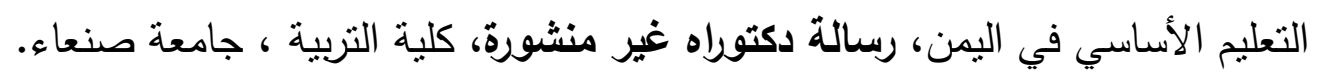

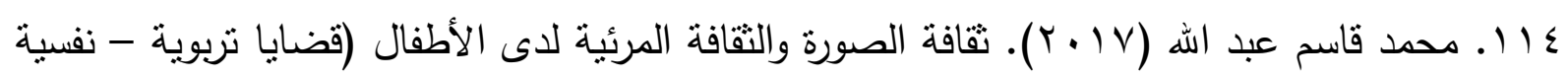

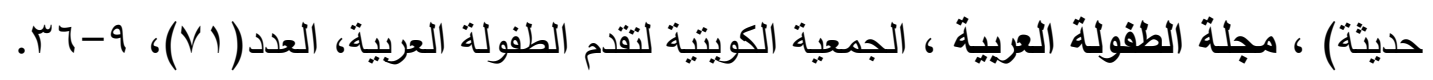
Retrieved June, 2017 from : http://jac-kw.org/images/947.pdf

110

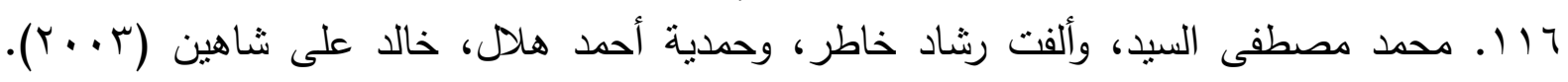
التربية الصحية والغذائية، القاهرة: دار الثقافة.

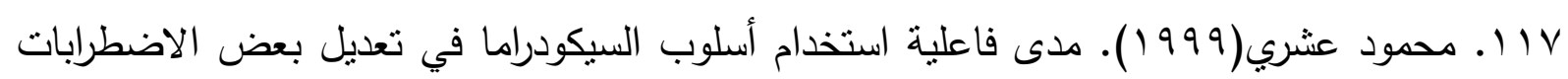

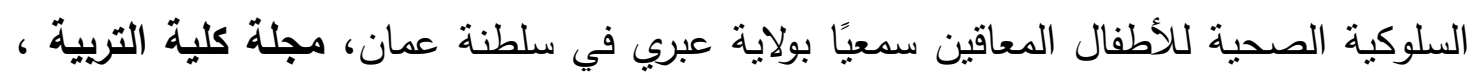

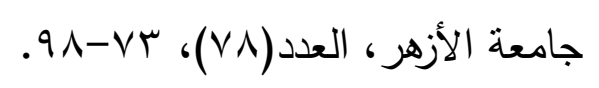

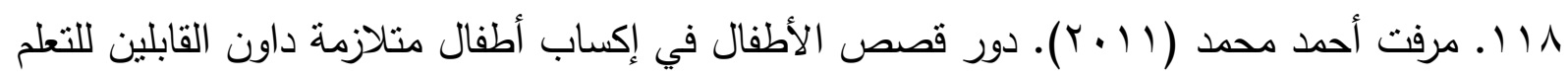

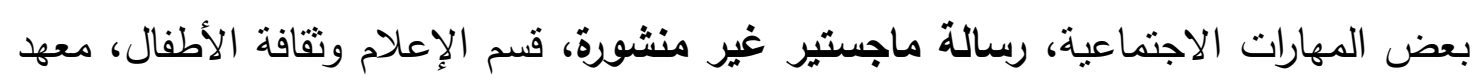
الدراسات العليا للطفولة، جامعة عين شمس.

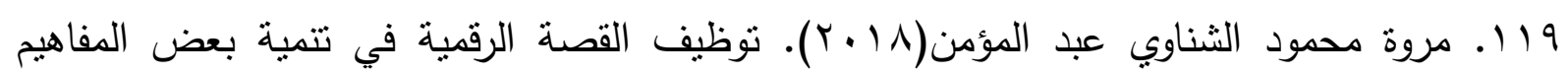

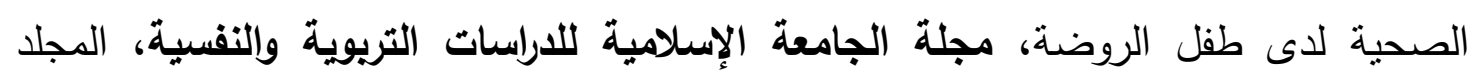

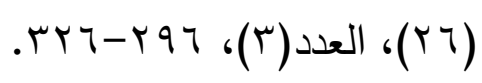

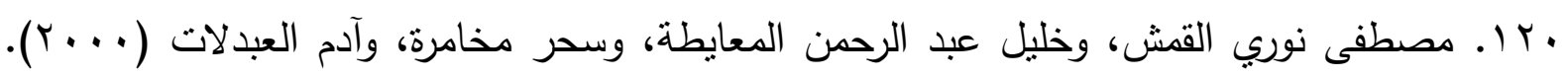

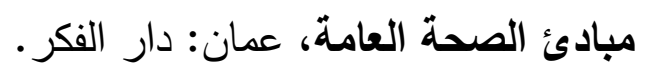

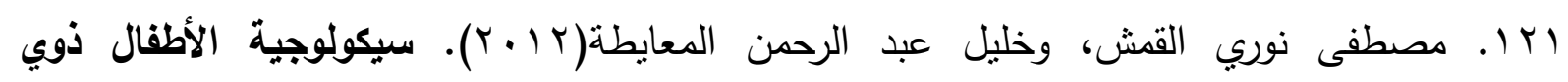

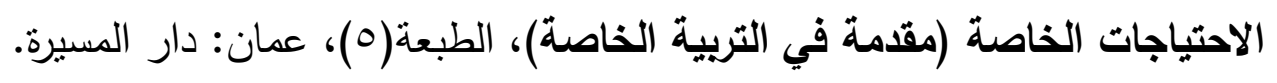

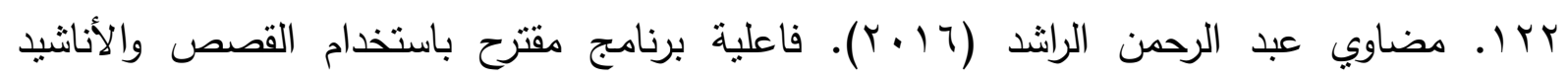

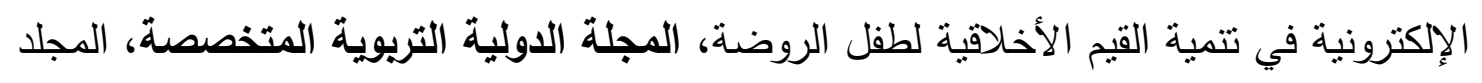

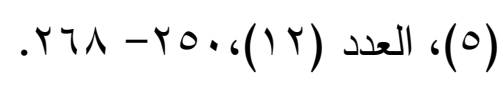

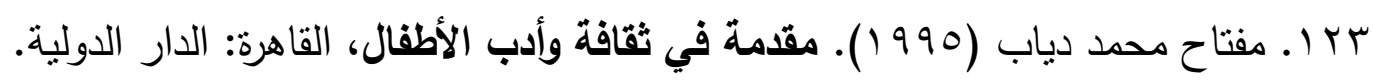

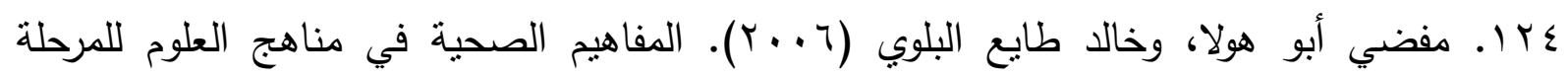

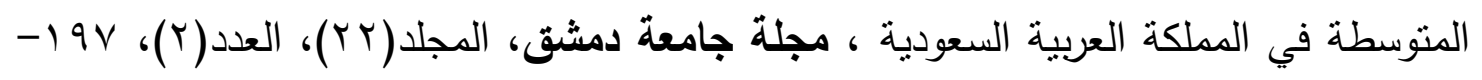
. $r \leqslant$.

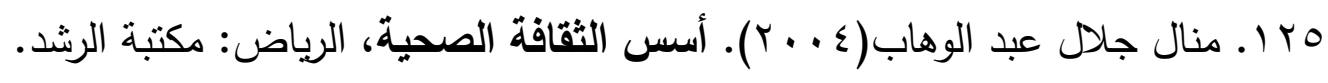

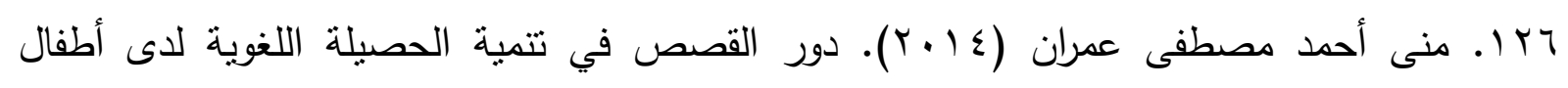

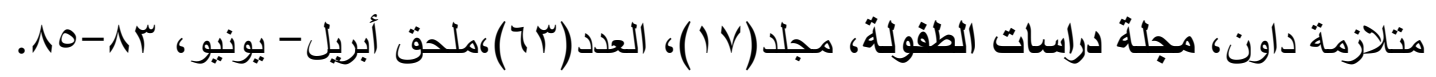




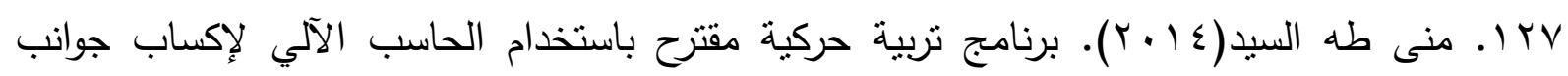

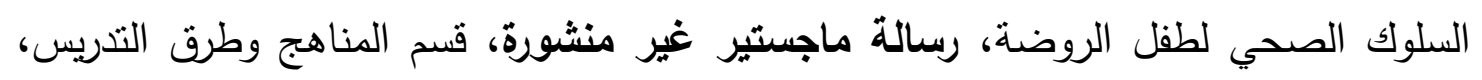
كلية التربية الرياضية، جامعة طنطا.

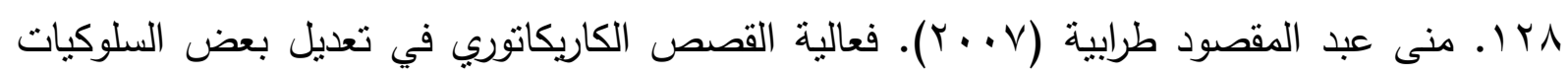

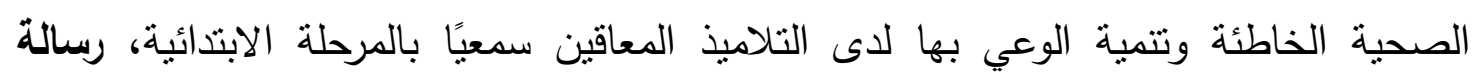
ماجستير غير منشورة، قسم المناهج وطرق التدريس، كلية التربية ، جامعة بنها.

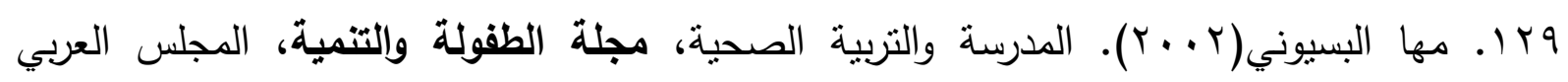

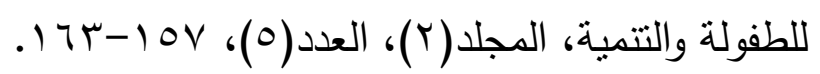

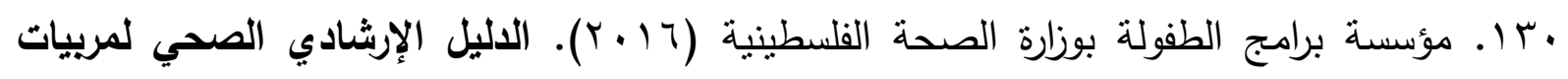

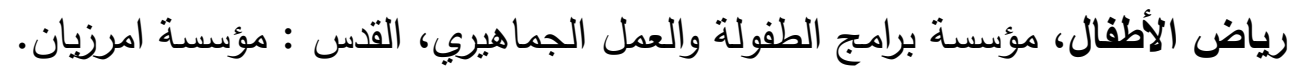

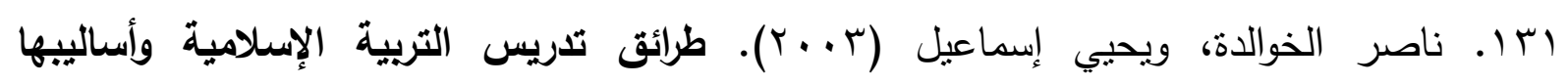

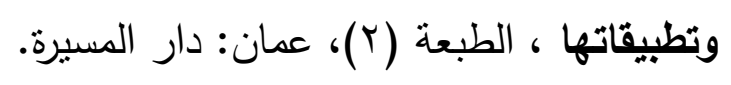

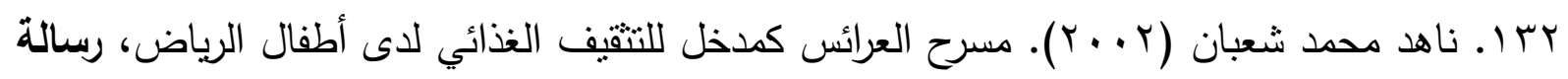

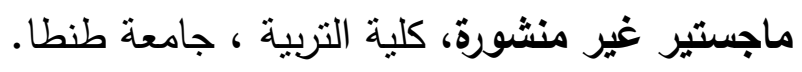

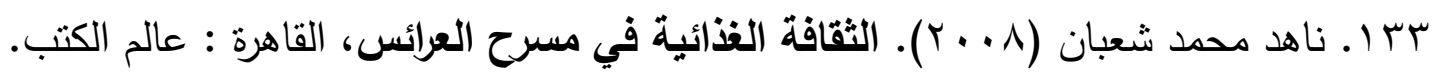

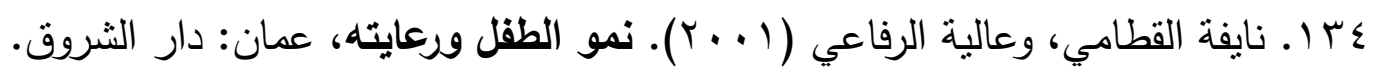

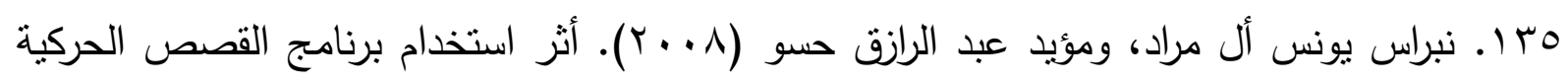

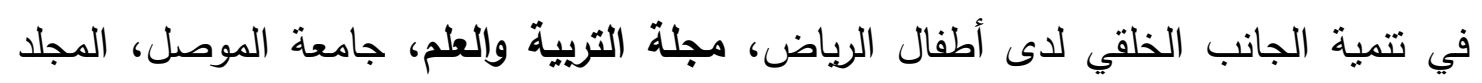

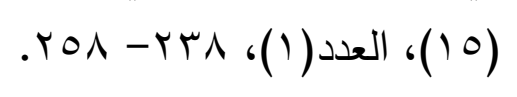

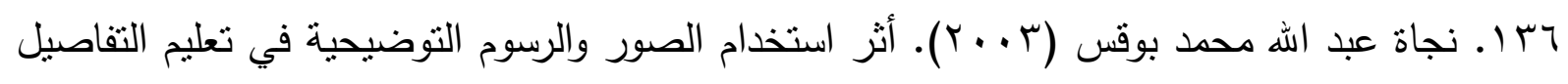

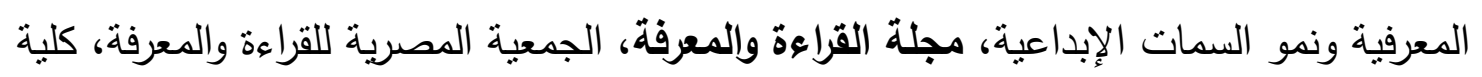

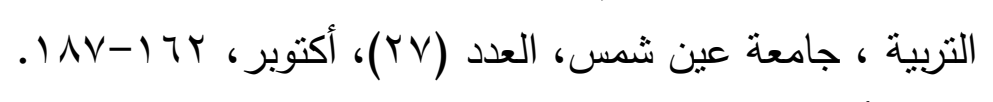

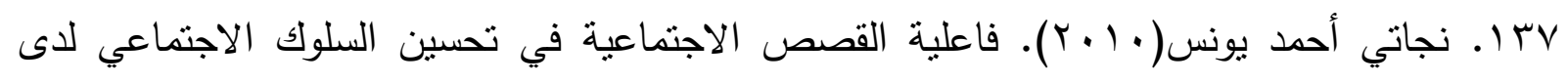

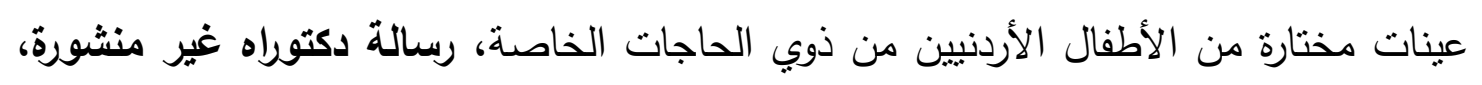
كلية الدراسات العليا، الجامعة الأردنية.

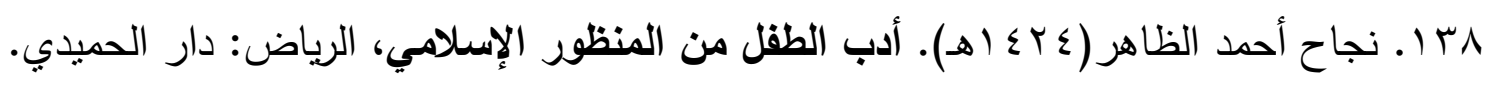

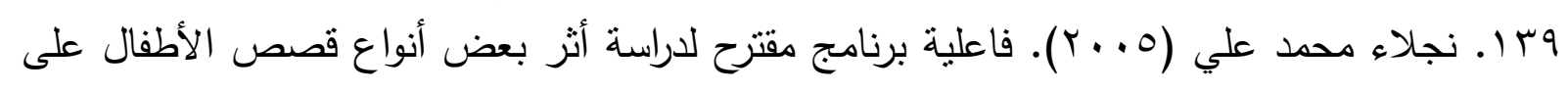

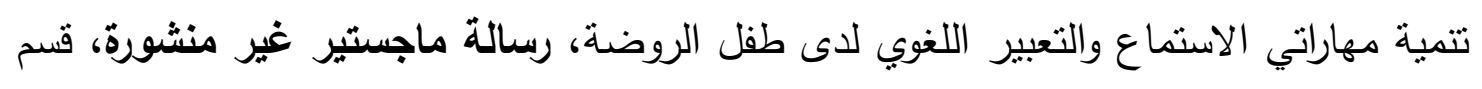
العلوم الأساسية، كلية رياض الأطفال، جامعة القاهرة.

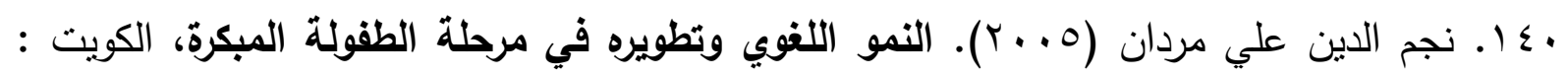
مكتبة الفلاح. 


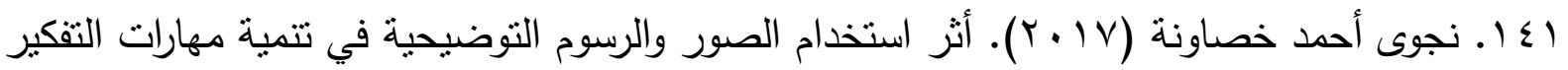
الناقد لدى تلميذات الصف الرابع في المرحلة الابتدائية وفي اتجاهاتهن نحو كتاب لغتي المطور،

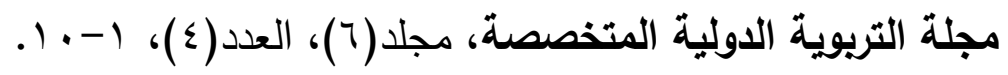

Retrieved May, 2017 from :http://www.iijoe.org/v6/IIJOE_01_04_06_2017.pdf

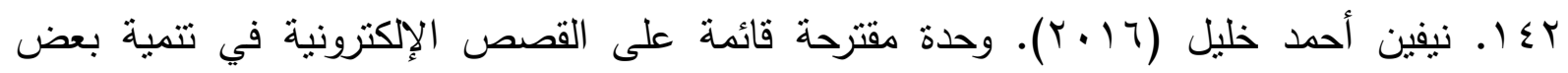

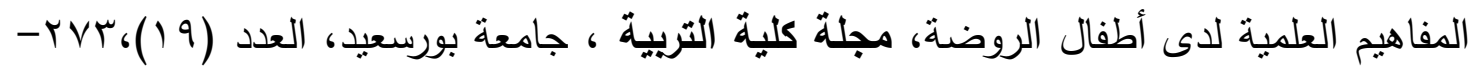
سו

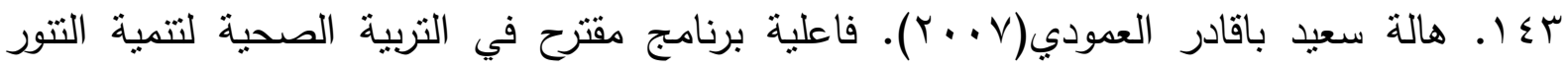
الصحي لاى تلميذات المرحلة المتوسطة بمدينة مكة المكرمة، رسالة دكتوراه غير منشورة، قسم المناهج وطرق التدربس، كلية التربية، جامعة أم القرى.

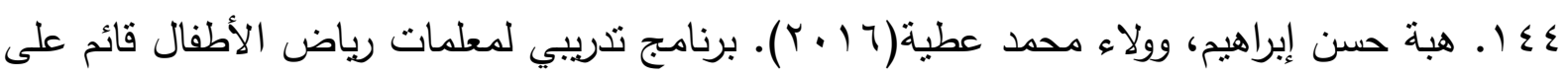
استخدام القصة لاكتساب طفل الروضة بعض المفاهيم التاريخية في العصر الفرعوني، مجلة

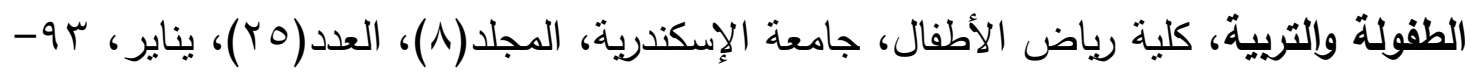

$.1 \mathrm{~V}$.

0 ا ـ هبة محمد عبد الحميد (T . . ץ). أدب الأطفال في المرحلة الابتدائية، عمان: دار صفاء. Tـ ا. هديل محمد عبد الله العرينان(10 • (Y). فاعلية استخدام القصة الإكترونية في تتمية بعض المهارات اللغوية لدى طفل الروضة ، رسالة ماجستير غير منشورة، قسم المناهج وطرق التدريس ، كلية التربية ، جامعة أم القرى.

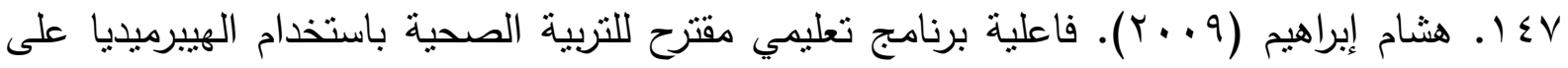
تتمية السلوك الصحي لتلاميذ المرحلة الابتدائية، رسالة دكتوراه غير منشورة، كلية التربية الرباضية بنين ، جامعة حلوان.

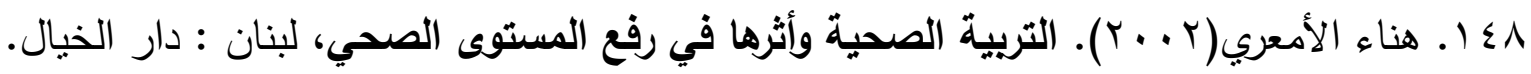
9 ا . هند ماجد البقمي(Y ( • (Y). فاعلية مسرح العرائس في تتمية المهارات الحياتية المتعلقة بوحدة صحتي وسلامتي لاى طفل الروضة بالعاصمة المقدة، رسالة ماجستير غير منشورة، كلية التربية ، جامعة أم القرى.

• 1. هيفاء عبد الله البسام (10 • ب). بعض صور التتوع (الثخصية، الثقافة، البيئة) في قصص الأطفال للأدب العربي والغربي: دراسة تحليلية مقارنة، مجلة رسالة التربية وعلم النفس، الجمعية

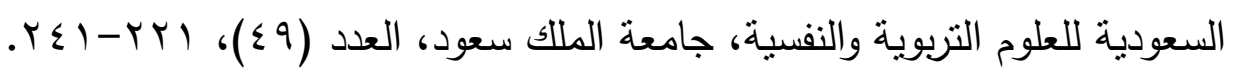
10 ا ـ وجدان الثمري (0 . . r). دور القصة في تثمية القدرات والسمات الإبداعية لاى أطفال الروضة، القاهرة : الدار العالمية. 


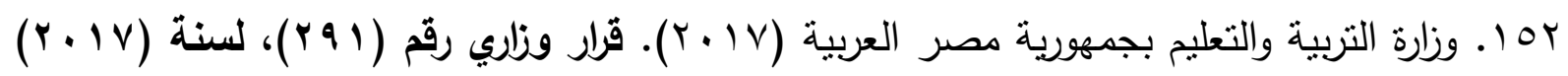
، بشأن إصدار اللائحة التنظيمية لمدارس وفصول التربية الخاصة، الإدارة العامة للتربية

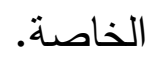

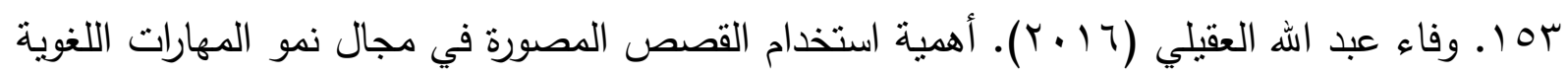

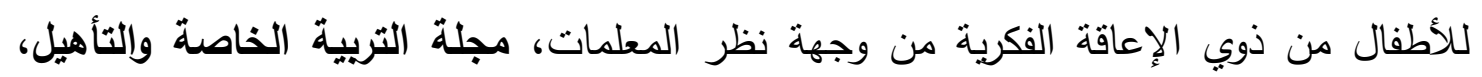

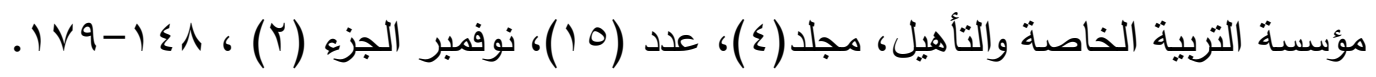

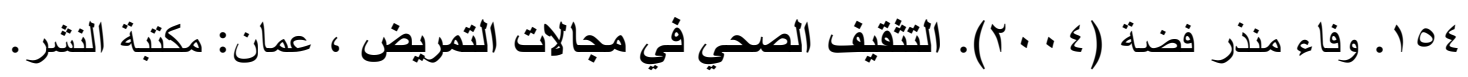

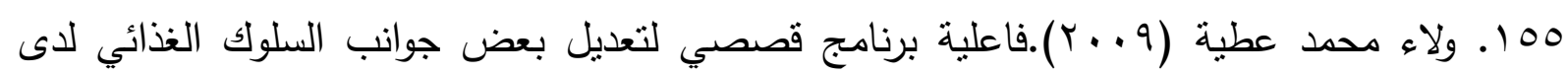

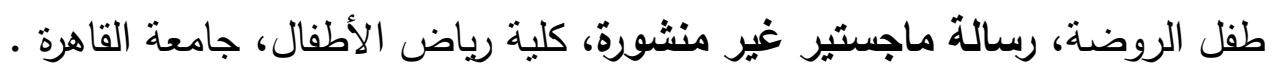

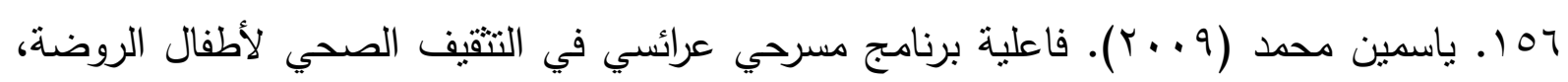

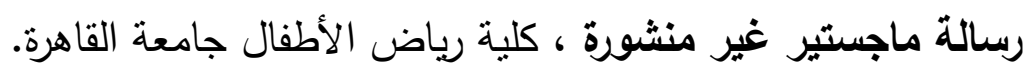

V V ا. يوسف محمود قطامي ، ورلى أحمد الفرا (9 . . r). التفكير الإبداعي القصصي للأطفال، عمان: دار المسيرة.

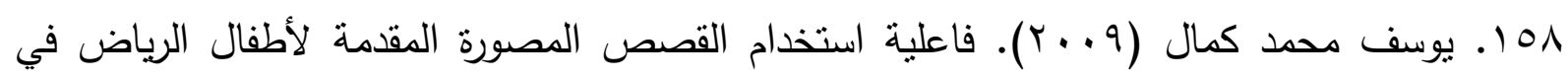

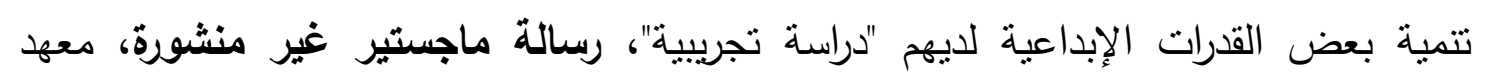

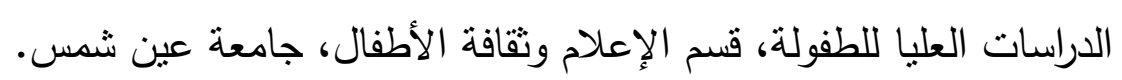

ثانياً: المراجع الأجنبية:

159. Adams ,L; Aphroditi ,G; Michael ,V\& Claire ,W(2004). Social Story Intervention: Improving Communication Skills in a Child With an Autism Spectrum Disorder ,Focus on Autism and Other Developmental Disabilities, Austin ;Summer ,(19),(2), 8-87.

160. Akker,M ;Maaskant, M \& Meijden, R(2006).Cardiac Diseases in People with Intellectual Disability ,Journal of Intellectual Disability Research, Jul 4(50), 515-522, Retrieved April, 2017 from : https://www.ncbi.nlm.nih.gov/pubmed/16774636

161. American Psychiatric Association (2013). Diagnostic and Statistical Manual of Mental Disorders DSM-5, 5th Edition, American Psychiatric Pub.

162. Association for Childhood Education International (2005). Retrieved June, 2017 from : https://www.acei.org/ 
163. Bader r, R. (2006). Using social stories to increase emotion recognition and labeling in school-age children with autism (Doctoral dissertation, Alliant International University,2006). Dissertation Abstracts International, 67(3), B, (UMI NO. 3209207).

164. Bennett, J.P.; Perko, M.A., \& Herstine, J.H (2000). National Practices in K-12 Health Education Physical Education Teachers Certification, Journal of Health Education ,National Center for Biotechnology Information, 31(3), 14-143.

165. Bishop, M \& Boag, E (2006). Teacher's Knowledge about Epilepsy \& Attitudes Toward Students With Epilepsy; Results of a national Survey , Epilepsy \&Behavior Journal ,Mar8 (2) ,397-405,Retrieved May, 2017 from :https://www.ncbi.nlm.nih.gov/pubmed/16406818

166. Bosch ,J \& Ringdahl ,J (2001). Functional Analysis of Problem Behavior in Children with Mental Retardation ,Continuing Education, Nov-Des, 26(6),11-307, Retrieved April, 2017 from : https://www.ncbi.nlm.nih.gov/pubmed/11725402

167. California State Board of Education(2008). Health Framework for California Public Schools Kindergarten Through Grade Twelve Adopted ,Department of Education; California_Department Retrieved May, 2017 from :https://www.cde.ca.gov/ci/cr/cf/documents/healthfw.pdf

168. Colby ,SE, \& Haldeman ,L (2007). Peer-led Theater as a Nutrition Education Strategy, Journal of Philadelphia, Nutrition Education Behaver, 7 (39),9-48

169. Connie ,J \&Bennett ,B ,2002). A Whole Health Curriculum for Young Children ,U,S ; State Maryland.

170. Cooper, S ;Melville ,C ;Morrison ,J ,Finlayson ,J; Allan, L; Martin, G, \& Robinson ,N(2006). Improving The Health of People with Intellectual Disabilities; Outcomes of A Health Screening Program After 1 Year, Journal of Intellectual Disability Research ,6(50),667-677. 
171. Douglas ,N; Warwick,I ; Whitty ,G\& Aggleton ,P (2000). Vital Youth:

Evaluation a Theatre in Health Education project, Health Education, Oct ,100( 5), 207-215 . DOI: 10.1108/09654280010343582

172. Fuhrman, J (2006).Disease- Proof Your Child Feeling Kids Right, 6th Edition, London; Martin's Press.

173. Gilbert ,G \& Sawyer, R \& McNeill ,E (2000). Health Education: Creating Strategies for School and Community Health ,4th Edition , London; Martin's Press.

174. Graetz ,H ;Javascript, V \& Janet ,E (2003). Promoting Social Behavior for Adolescent With Autism With Social Stories, PH ,D, George Mason University.

175. Hallahan, D; Kauffman ,J\& Pullen, P(2013). Exceptional Learners: An Introduction to Special Education ,Boston: Allyn and Bacon.

176. Harvey ,D (2004). The Good Housekeeping Book of Child Care ,U,S ; Washington .

177. Hudspeth, K ;Nelson ,N\& James ,A (2009). For Children Dynamic Cues and Stories are More Powerful Cues to Emotion Than are Facial Expressions ,Society for Research in Child Development Meeting ,Research in Child Development Meeting :Boston College.

178. Johnathan ,M(2004). The Child and His Curriculum, London: Mercury Book.

179. Kann ,L \& Brener, N (2001). Health Education ,Result from The School Health Education Policies and Programs Study, Journal of School Health, 6(71), $266-278$.

180. Kastner, T.; Walsh, K.\& Fraser, M. (2001). Undiagnosed medical conditions and medication side effects presenting as behavioral/psychiatric problems in people with mental retardation, Mental Health Aspects of Developmental Disabilities, 3(4), 101107.

181. Lin ,J,Y; en,C; Li,C \&Wu,J (2005). Patterns of Obesity Among Children and Adolescents and Adolescents With Intellectual Disabilities in 
Taiwan, Journal of Applied Research in Intellectual Disabilities, 4 (18), 123-129.

182. Luknes, $R(2006)$. A Critical Hand Book of Children's Literature, Boston: Allyn and Bacon.

183. Mahoney, B, \& Olsen, L (1993). Health education teacher resource handbook. A practical guide for $\mathrm{K}-12$ health education. Millwood, NY: Kraus International Publications.

184. Malville, C; Hamiltion ,S; Hankey ,C; Miller,S \& Boyle,S(2007). The Prevalence and Determinants of Obesity in Adults With Intellectual Disabilities, Journal of Health Education, National Center for Biotechnology Information, May 8(3), 30-223. DOI:10.1111/j.1467789X.2006.00296.x

185. Michael B, ; Raymond ,G ; Christopher, F, \& Brian ,G (2004). Teaching Safety Skills to Prevent Gun, Play, Journal of Applied Behavior Analysis are provided here courtesy of Society for the Experimental Analysis of Behavior, Journal of Health Education ,National Center for Biotechnology Information Spring ;37,(1),1-9. DOI : 10.1901/jaba.2004.37-1

186. Mukherjee, S; Lightfoot, J \& Sloper, P (2000)The inclusion of pupils with a chronic health condition in mainstream school: what does it mean for teachers?, Social Policy Research Unit, The York Research Database ,42 (14), 59-72.

187. National Association for The Education of Young Children(NAEYC) (2017) : Health Education Standards, Retrieved April , 2017 from :

$$
\text { https://www.naeyc.org/our-work/families/10-naeyc-program- }
$$

standards\#5

188. National Institute of Education (2014). A Study of Integrating Technology Into Science Learning ,Singapore; Helsinki University 189. O'Neill, L, \& Dalton, B. (2002). Supporting Beginning Reading in Children with Cognitive Disability Through Technology. Exceptional Parent, 32(6), 40-43. 
190. Richter ,S \& Test , D (2011) .Effects of Multimedia Social Stories on

Knowledge of Adult Outcomes and Opportunities among TransitionAged Youth with Significant Cognitive Disabilities, Education and Training in Autism and Developmental Disabilities, 46(3), 410-424

191. Shui, S(2001). Issues in The Education of Student with Chronic Illness,

International Journal of Disability Development and Education, September, 48(3):269-281. DOI: 10.1080/10349120120073412

192. Taras, H ,\& Potts-Datema ,W. (2005). Chronic Health Conditions and Student Performance at School, Journal of School Health, Journal of Health Education, National Center for Biotechnology Information,Sep;75(7):255-66. DOI:10.1111/j.17461561.2005.00034.x

193. Van ,H (2005). Health in People with Intellectual Disabilities; Current Knowledge\& Gapes in Knowledge ,Journal of Applied Research in Intellectual Disabilities,4(18),325-333.

194. Walders , N, Mcqauid ,E \&Dickstein ,S (2004). Asthma Knowledge , Awareness, and Training among Head Start and early Head Start Staff , Journal of School Health ,6 (74), 32-34.

195. Walker ,A (2005). Eat, Play, and Be Healthy (A Harvard Medical School Book).New Your: McGraw Hill Professional

196. Wang ,K; Hsieh ,K ;Heller,K; Davidson ,P \& Janicki,M (2006). Career Report of Health Status Among Adult with Intellectual- Development Disabilities in Taiwan Living at Home and in Institutions, Journal of Intellectual Disability Research ,3 (41),42-51.

197. William, C(2001). The Relationship Between Health Education and Health promotion: A personal Perspective .Journal of Health Education ,National Center for Biotechnology Information, 32(6),369370 .

198. Zigler ,E ; Gilliam ,W\& Jones ,S (2006). A Vision for Universal Preschool Education, Cambridge University Press . 